LAÍS DE ALMEIDA CARDOSO

A INFÂNCIA REVISITADA:

UM ESTUDO SOBRE O PROTAGONISMO INFANTIL

NA LITERATURA BRASILEIRA AO RAIAR DO SÉCULO XX

[Versão corrigida]

SÃO PAULO 


\title{
A infância revisitada: um estudo sobre o protagonismo infantil na literatura brasileira ao raiar do século $\mathrm{XX}$
}

\author{
Laís de Almeida Cardoso
}

Tese apresentada à Banca Examinadora como exigência parcial para a obtenção do título de Doutora em Letras pelo Programa de PósGraduação em Estudos Comparados de Literaturas de Língua Portuguesa do Departamento de Letras Clássicas e Vernáculas da Faculdade de Filosofia, Letras e Ciências Humanas da Universidade de São Paulo, sob a orientação da Profa $\stackrel{\text {. Dra }}{\text { a }}$ Maria Zilda da Cunha.

São Paulo 
Autorizo a reprodução e divulgação total ou parcial deste trabalho, por qualquer meio convencional ou eletrônico, para fins de estudo e pesquisa, desde que citada a fonte.

Catalogação na Publicação

Serviço de Biblioteca e Documentação

Faculdade de Filosofia, Letras e Ciências Humanas da Universidade de São Paulo

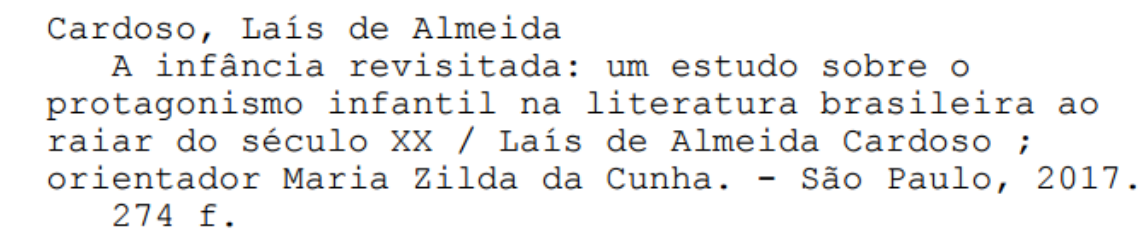

Tese (Doutorado)- Faculdade de Filosofia, Letras e Ciências Humanas da Universidade de São Paulo. Departamento de Letras Clássicas e Vernáculas. Área de concentração: Estudos Comparados de Literaturas de Língua Portuguesa.

1. Infância. 2. Representação. 3. Literatura Brasileira. 4. Século Xx. I. Cunha, Maria Zilda da, orient. II. Título. 


\section{FOLHA DE APROVAÇÃO}

\section{Laís de Almeida Cardoso}

A infância revisitada: um estudo sobre o protagonismo infantil na Literatura Brasileira ao raiar do século $\mathrm{XX}$

Tese apresentada à Banca Examinadora como exigência parcial para a obtenção do título de Doutora em Letras pelo Programa de PósGraduação em Estudos Comparados de Literaturas de Língua Portuguesa do Departamento de Letras Clássicas e Vernáculas da Faculdade de Filosofia, Letras e Ciências Humanas da Universidade de São Paulo, sob a orientação da Prof ${ }^{\mathrm{a}}$. Drª . Maria Zilda da Cunha.

Aprovada em:

Banca Examinadora:

$\operatorname{Prof}(\mathrm{a}) \cdot \operatorname{Dr}(\mathrm{a})$.

Instituição: Assinatura:

$\operatorname{Prof}(\mathrm{a}) . \operatorname{Dr}(\mathrm{a})$.

Instituição: Assinatura:

$\operatorname{Prof}(\mathrm{a}) \cdot \operatorname{Dr}(\mathrm{a})$. Instituição: Assinatura:

$\operatorname{Prof(a).~Dr(a).~}$

Instituição: Assinatura:

Prof(a). Dr(a). Instituição: Assinatura: 
Para meus pais,

Zelia e Odon 
Para todas as crianças

que fizeram e continuam fazendo parte da minha vida: meus irmãos, meus amigos, meus alunos, meus sobrinhos, meus leitores 
Em memória de

Antonio Candido

(1918-2017)

"Um artista nada mais faz do que tomar os lugares-comuns e renová-los pela criação" 


\section{Agradecimentos}

Por mais autonomia e dedicação que um pesquisador apresente no desenvolvimento de seu trabalho, uma tese de doutorado não se constrói de forma isolada. São tantas as pessoas que fizeram parte desta minha trajetória para que eu pudesse chegar até aqui...

Começando pelo fim, agradeço à querida Profa. Dra. Maria Zilda da Cunha, pela paciência no acompanhamento da redação desta tese, pelas leituras e sugestões, pelo cuidado e pelos incentivos constantes durante todo o curso de Doutorado; ao Prof. Dr. José Nicolau Gregorin Filho, cuja presença foi tão importante nesta caminhada, tanto pela oportunidade que me deu de voltar à Universidade de São Paulo como sua aluna e pelas orientações durante o exame de qualificação, como por seus comentários e indagações durante a defesa da tese; aos Professores Doutores Regina Michelli, Maria Aparecida Junqueira e Ricardo Iannace, que completaram a minha banca de doutorado, pelo tempo dedicado à leitura da tese e pelas pertinentes observações sobre o trabalho; ao Prof. Dr. José Maria Rodrigues Filho, pelo incentivo e pelas sugestões durante o exame de qualificação. E gostaria de terminar esta primeira parte dos agradecimentos com um sincero reconhecimento aos professores que tive durante a minha vida e que me inspiraram com seus ensinamentos. Uma menção especial ao Prof. Dr. Joaquim Alves de Aguiar (in memoriam), que me introduziu nos estudos literários e me despertou para a pesquisa acadêmica tanto por meio de suas brilhantes aulas como pelos auspiciosos comentários que deixou em cada um de meus trabalhos de graduação.

Algumas pessoas me ajudaram grandemente no processo de redação do meu texto, no entrelaçamento das ideias, no desenvolvimento da pesquisa, ou simplesmente participando comigo desta jornada. Assim, não tenho palavras suficientes para agradecer à minha querida amiga Karla Swartz, que mesmo estando longe acompanhou de perto cada etapa da elaboração desta tese com sua leitura atenta, seu constante encorajamento, e, principalmente, com sua disponibilidade para conversar e me ouvir. Agradeço ainda sua preciosa ajuda na tradução dos textos em inglês e na redação do Abstract.

Agradeço também à minha irmã, Profa. Dra. Elis de Almeida Cardoso Caretta, pelo incentivo e ajuda em todos os momentos, desde minha entrada no Doutorado; aos historiadores Cauby Dantas e Diane Valdez, e à colega Fabiana Tavares, pela gentileza ao disponibilizarem seus textos para consulta; aos integrantes do Grupo de Pesquisa Produções Literárias e Culturais para Crianças e Jovens e aos colegas da Pós-Graduação, em especial, ao Euclides Lins, pela amizade e pelo companheirismo.

Também não posso deixar de agradecer a todos os meus amigos pessoais (vocês sabem quem são), meus irmãos e familiares, que me incentivaram e me apoiaram durante o curso de Doutorado, entenderam minhas ausências, respeitaram meus silêncios e meus momentos de reclusão e, hoje, se alegram comigo. Agradeço ainda aos colegas de trabalho e à Direção do Colégio Presbiteriano Mackenzie Tamboré, que sempre estiveram na torcida por mim. 
Para encerrar, um agradecimento mais que especial a duas pessoas, sem as quais, nada teria sido possível: meu saudoso pai, Odon Almeida Cardoso (in memoriam), cujo espírito alegre e apaixonado pela literatura é constante fonte de inspiração para mim - e sempre há de me acompanhar -, e minha querida mãe, Profa. Dra. Zelia de Almeida Cardoso, que esteve comigo desde o princípio, ensinando-me, com seu exemplo, a ser uma pessoa melhor. Agradeço não somente as várias leituras que fez deste trabalho e os momentos de conversa, incentivo e ajuda, mas todo o seu desprendimento e sua dedicação para que, em tempos distantes, eu e meus irmãos pudéssemos ter uma infância feliz. É especialmente a ela que dedico este trabalho. 


\section{Resumo}

\section{A infância revisitada: um estudo sobre o protagonismo infantil na literatura brasileira ao raiar do século $\mathrm{XX}$}

O objetivo da presente pesquisa foi estudar as representações da infância na literatura brasileira em uma época marcada por importantes transformações políticas, sociais e econômicas, não somente no Brasil, mas em todo o mundo - a primeira metade do século XX. Desse período, compreendido mais especificamente entre 1920 e 1945, elencamos para o estudo quatro textos que apresentam perfis de diferentes protagonistas infantis: o conto "Negrinha", de Monteiro Lobato, integrante da coletânea homônima publicada em 1920, e os romances Menino de engenho, de José Lins do Rego (1932), Capitães da Areia, de Jorge Amado (1937) e Infância, de Graciliano Ramos (1945). Enquanto o conto lobatiano precede a eclosão do Modernismo, os três romances analisados fazem parte do chamado movimento regionalista nordestino, que se estabeleceu especialmente durante a década de 1930 e apresentou como principais novidades a liberdade temática e o vigor estilístico na prosa literária. 0 intervalo de tempo escolhido, localizado entre o prenúncio e o fim do movimento modernista, revelou outra interessante "coincidência": ao mesmo tempo que de um lado diferentes autores dedicavam-se a escrever sobre a infância brasileira, de outro se constituía - por meio das obras infantis do próprio Monteiro Lobato - uma literatura infantil genuinamente brasileira. Tomando os estudos sociológicos de Gilberto Freyre acerca das relações sociais e da constituição da família brasileira nos séculos anteriores ao período estudado, tivemos também como interesse durante a pesquisa buscar nos textos de ficção traços da infância descrita pelo sociólogo e vestígios de uma sociedade patriarcal e escravocrata. E, por fim, a partir de um breve estudo biográfico de cada um dos autores estudados, procuramos estabelecer ainda algumas relações entre infância, juventude, memória e criação. Como resultado de nossa análise, constatamos que, apesar das diferenças entre estilos e contextos que permeiam as quatro narrativas, alguns temas são recorrentes em todas elas, promovendo diálogos possíveis. Vestígios da escravidão, castigos corporais a que as crianças são submetidas, contraposição entre liberdade e sujeição e a despedida da infância são alguns deles. Considerando-se também o cenário sociocultural em que as obras foram concebidas e as histórias de vida de seus autores, é possível concluir que, mais que retratos esparsos de crianças construídas "de papel e tinta", os textos, em seu conjunto, trazem-nos importantes reflexões sobre a infância no Brasil nesse período situado na primeira metade do século XX.

Palavras-chave: 1. Infância. 2. Representação. 3. Literatura Brasileira. 4. Século XX. 


\section{Abstract \\ Childhood revisited: a study about children as leading characters in Brazilian literature in the early $20^{\text {th }}$ century}

This study aims to analyze representations of childhood in Brazilian literature during the first half of the $20^{\text {th }}$ century, more specifically between 1920 and 1945, a period in which substantial changes occurred in politics, economics, and society worldwide. For this purpose, I explored connections between four Brazilian literary pieces that present children as main characters, as follows: a short story by Monteiro Lobato, 'Negrinha' (1920), and three novels - Menino de engenho (Plantation Boy, 1932) by José Lins do Rego, Capitães da Areia (Captains of the Sand, 1937) by Jorge Amado, and Infância (Childhood, 1945) by Graciliano Ramos. Whereas 'Negrinha' precedes the advent of Modernism, the remaining fictional works encompass examples of the Brazilian Regionalist Movement, which emerged during the 1930s, highlighting innovations in literary prose, such as thematic freedom and stylistic vigor, also portraying hardships of population in the Brazilian interior backlands. The time frame outlined in this study reveals a remarkable coincidence - while some Brazilian authors were devoted to write about Brazilian childhood, Monteiro Lobato publishes his groundbreaking masterpieces which determines the rise of children's literature in Brazil. This research also addresses sociocultural aspects of patriarchy and slavery in the literary pieces studied, taking into account the extensive sociological studies by Gilberto Freyre about Brazilian cultural and social heritage which was shaped by a high degree of miscegenation amidst Portuguese settlers, native Brazilians, and African slaves. Upon brief analysis of the author's biographies, this study also examines relationships between childhood, youth, memory, and creation. Ultimately, this research demonstrates that despite the differences amid writing styles and contexts in which the four narratives were written, some of the themes are recurrent, including physical punishment of children, farewell to childhood, historical legacy of slavery, and contrasts between freedom and subservience. To conclude, these works are more than children's portraits crafted on 'paper and ink' - the results of this analysis reveal that the literary pieces studied are closely related and intertwined, therefore it will certainly provide valuable insights into childhood in Brazil in the early $20^{\text {th }}$ century.

Keywords: 1. Childhood. 2. Representation. 3. Brazilian literature. 4. 20th Century. 


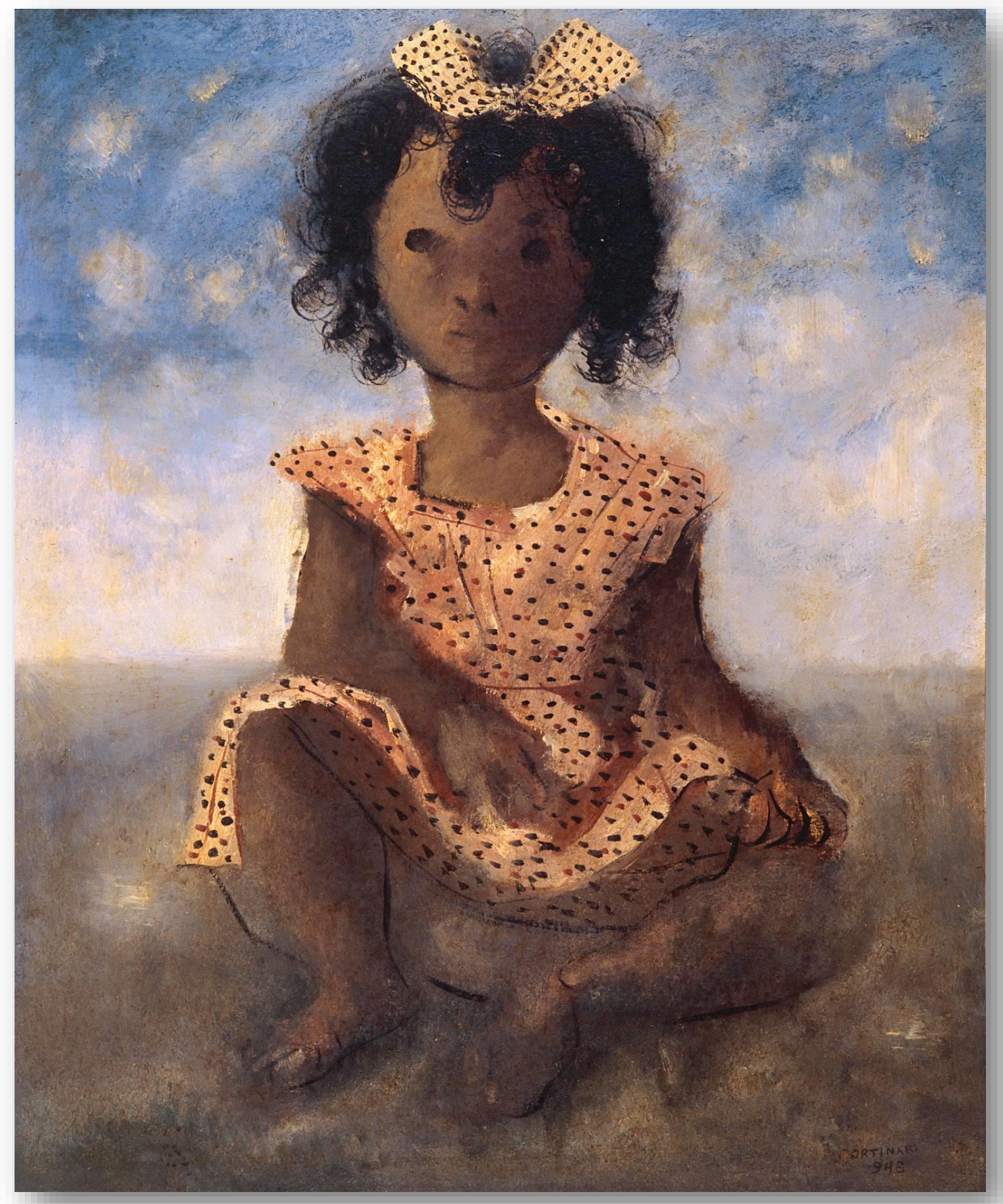

Candido Portinari. Menina sentada

(1943) 


\section{Sumário}

Introdução

Capítulo 1 - A infância na narrativa literária …....................................................................................... 18

1.1 Considerações iniciais ................................................................................................................. 19

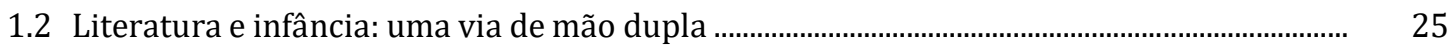

1.3 A literatura brasileira ao raiar do século XX: rupturas e ressignificações .............................. 48

1.4 A Semana de 22 e a eclosão do movimento modernista ........................................................... 52

Capítulo 2 - Lobato, literatura e infância ……..........................................................................................

2.10 neto do Visconde ...................................................................................................................

2.2 Revelações e impressões de Lobato sobre a infância ................................................................ 68

2.3 Um filhote de livro .......................................................................................................................

2.4 "Negrinha", a menina que desconhecia a infância .....................................................................

Capítulo 3 - “Verdes anos": reminiscências de um menino de engenho ........................................... 100

3.1 José Lins do Rego: infância e memória ..................................................................................................... 101

3.2 Gilberto e José: um encontro de "meninos de engenho" em uma "tarde de Recife”............ 106

3.3 Uma literatura "cheirando a canavial e melaço da terra" .......................................................... 120

3.4 A infância de um "menino perdido" ................................................................................................... 128

3.5 Menino de engenho e a jornada do herói ......................................................................................

Capítulo 4 - Entre meninos e homens: infância e sociedade em Capitães da Areia ..................... 146

4.1 Sociedade e infância no Brasil: a rua como lar ........................................................................... 148

4.20 menino grapiúna, um contador de histórias .......................................................................... 164

4.3 "Sob a lua, num velho trapiche abandonado" ............................................................................. 177

4.4 As luzes do carrossel e o resgate da infância ................................................................................ 182

4.5 Infâncias roubadas ...................................................................................................................... 188

Capítulo 5 - Fragmentos de infância em Graciliano Ramos ................................................................ 200

5.1 A imprecisão da memória e as lembranças como "rasgões num tecido negro" .................... 201

5.2 Infância, insignificância e justiça: “como as aranhas que trabalham na teia negra” ........... 211

5.30 barão de Macaúbas e a mosca que caiu no fogo ......................................................................... 226

5.4 Fabiano, o menino mais velho e o narrador de Infância: elos e conexões entre memória e criação 


\section{Infância}

Meu pai montava a cavalo, ia para o campo.

Minha mãe ficava sentada cosendo.

Meu irmão pequeno dormia.

Eu sozinho menino entre mangueiras

lia a história de Robinson Crusoé, comprida história que não acaba mais.

No meio-dia branco de luz uma voz que aprendeu a ninar nos longes da senzala - e nunca se esqueceu chamava para o café.

Café preto que nem a preta velha café gostoso café bom.

Minha mãe ficava sentada cosendo olhando para mim:

- Psiu... Não acorde o menino.

Para o berço onde pousou um mosquito.

E dava um suspiro... que fundo!

Lá longe meu pai campeava

no mato sem fim da fazenda.

E eu não sabia que minha história era mais bonita que a de Robinson Crusoé. 


\section{Introdução}

"Toutes les grandes personnes ont d'abord été des enfants. (Mais peu d'entre elles s'en souviennent.)"

Antoine de Saint -Exupéry

$(1943)^{1}$

Escrever sobre a infância é, de certo modo, fazer uma viagem ao passado. É procurar nas lembranças adormecidas as imagens da criança que todos fomos um dia, e resgatar nos arquivos mais antigos da memória as pessoas, os lugares, os fatos e acontecimentos; as tristezas, as surpresas, as alegrias e os sentimentos que nos marcaram para sempre, que nos mostraram por onde deveríamos seguir e nos foram transformando em quem nos tornamos.

Mas escrever sobre a infância é também uma maneira de perscrutar o futuro. Ao observar uma criança crescendo e acompanhar seu aprendizado, seus primeiros passos, sua linguagem, suas descobertas, seu olhar sempre atento a tudo o que a cerca, podemos caminhar lado a lado com esse pequeno ser que vai se desenvolvendo e descobrindo o mundo que o cerca, ora percorrendo atalhos previamente traçados, seguindo os passos dos seus antecessores, ora abrindo novas trilhas, fazendo percursos com seus próprios pés.

1 “Todos os adultos um dia foram crianças. (Mas poucos deles se recordam)". SAINT-EXUPÉRY, A. Le petit Prince (1943). 
Nestas primeiras décadas de século XXI, estudiosos de vários campos do saber têm-se dedicado a aprofundar-se nos estudos sobre a criança e no debate que envolve os termos "infância" e "novo milênio". Nos mais diversos meios de comunicação, discutem-se as relações entre criança e tecnologia, criança e redes sociais, criança e sexualidade, criança e educação, criança e seu papel na família, entre outras. A infância está em evidência nas propagandas, nas telenovelas, no cinema, nos musicais, na indústria fonográfica, nos canais pagos que dedicam vinte e quatro horas por dia de sua grade a uma programação exclusivamente infantil. Está presente também nos jogos, nos aplicativos e games desenvolvidos especialmente para essa faixa etária; nos equipamentos eletrônicos, nos brinquedos, nos livros e objetos, e em toda a indústria do entretenimento projetada para atrair e sustentar um número cada vez maior de crianças e adolescentes em sua teia de comunicação.

De acordo com a historiadora Mary Del Priore ${ }^{2}$, em análise da situação atual ${ }^{3}$ da criança no Brasil, "o comércio e a indústria de produtos infantis vêm aumentando progressivamente sua participação na economia, assim como a educação primária e o combate à mortalidade infantil tornam-se temas permanentes da política nacional" (2013, p. 7). Desse modo, a autora enfatiza a mobilização cada vez maior de especialistas e profissionais de diferentes áreas do saber nesse olhar multifacetado para a infância, neste século em que o protagonismo infantil é evidente, proporcionando até mesmo uma inversão de papéis - em alguns casos -, seja nas relações familiares, nos estabelecimentos de ensino, na sociedade. Para Del Priore,

o bem-estar e o aprimoramento das relações entre pais e filhos são assuntos constantes de psicólogos, sociólogos, psicanalistas, enfim, de especialistas, que, além de produzirem uma contribuição inédita para uma melhor inserção da criança na sociedade do ano 2000, veiculam seus conhecimentos em revistas e teses, propondo uma nova ética para a infância (DEL PRIORE, 2013, p. 7).

\footnotetext{
2 Mary Lucy Murray Del Priore (1952). Historiadora e professora brasileira, especialista em história da infância no Brasil.

${ }^{3}$ A autora se refere aos anos 1990 (data da primeira publicação: 1991).
} 
A medicina é um exemplo de área do conhecimento que se tem ocupado continuamente da criança e contribuído de forma decisiva para tentar elucidar mais pormenorizadamente as etapas biológicas da maturação infantil. Estudos recentes da neurociência classificam os primeiros anos de vida como a fase mais importante e crucial para a formação da arquitetura do cérebro humano, e a neurociência aplicada à educação já é uma área de trabalho que vem ganhando cada vez mais adeptos, entre pesquisadores e estudiosos interessados em entender tanto os mecanismos que levam a criança ao aprendizado e ao desenvolvimento cognitivo, como os transtornos envolvidos quando há falhas nesse complexo sistema (COSENZA \& GUERRA, 2011).

A sociologia também é uma área que tem revelado, nas últimas décadas, vários estudos sobre a infância. De acordo com as pesquisadoras Anete Abramowicz ${ }^{4}$ e Fabiana de Oliveira ${ }^{5}$, embora um interesse pelo estudo sociológico da infância já se venha acentuando desde meados do século XX, "é a partir dos anos 1980 que um campo teórico irá se constituir para 'disputar' este saber, que de alguma maneira pertencia à Psicologia e à Medicina [...]". Desse modo, "a criança e sua infância sairão do interregno em que estavam colocadas". Para as autoras, no Brasil, a Sociologia da Infância "como campo começará a se constituir a partir da década de 906, na confluência entre os pedagogos e os sociólogos prioritariamente"(ABRAMOWICZ \& OLIVEIRA, 2010, p. 41).

Para a pesquisadora Maria Walburga dos Santos ${ }^{7}$, em resenha sobre o livro Sociologia da Infância no Brasil" ,

expressões caraterísticas da Sociologia da Infância, como culturas infantis, culturas de pares, cultura da infância, categoria geracional, sujeito de direito, ator social vêm sendo apropriadas e passam a fazer parte do repertório de pesquisa da área de infância. Desde a década de 1990, o campo só cresceu no mundo e no Brasil: publicações, teses, pesquisas, apresentações em congressos e seminários, marcam o campo e revelam suas características e relevância (SANTOS, 2012, s/p).

\footnotetext{
${ }^{4}$ Anete Abramowicz. Doutora em Educação. Docente do curso de Pedagogia e da Pós-Graduação em Educação e Sociologia da Universidade Federal de São Carlos (UFSCar-SP).

${ }^{5}$ Fabiana de Oliveira. Doutora em Educação; Professora da Universidade Federal de Alfenas (Unifal-MG).

${ }^{6}$ As autoras referem-se aos anos 90 do século XX.

7 Maria Walburga dos Santos. Doutora em Educação pela Universidade de São Paulo; docente na Universidade Federal de São Carlos.

8 FARIA, Ana Lúcia Goulart de; FINCO, Daniela (Org.). Sociologia da Infância no Brasil. Campinas, SP: Autores Associados, 2011.
} 
Porém, embora realmente esse período localizado entre o final do século XX e as primeiras décadas do século XXI venha sendo caracterizado por um protagonismo infantil evidente em todas as esferas da sociedade moderna, estudos mais aprofundados sobre a infância e suas necessidades já vêm de longa data - em especial, a partir do século XVIII -, quando em distintas áreas do saber a atenção se voltou para essa fase da vida que, até então, era pouco conhecida em suas especificidades.

Apenas para citar alguns exemplos, observamos como a psicologia e a pedagogia têm desempenhado - desde o fim do século XIX - um papel fundamental no estudo do desenvolvimento da criança e do modo como ela apreende o mundo e com ele se relaciona. Nesse sentido, Jean Piaget (1896-1980) estabeleceu um marco com suas pesquisas sobre as várias fases do desenvolvimento infantil. A linguagem e o pensamento na criança, sua primeira obra, editada nos anos 1920, traz suas impressões iniciais sobre o processo de aquisição de conhecimento pela criança, e ainda hoje é referência para os estudiosos da educação. No campo da psicanálise e dos primeiros estudos a respeito da relação entre infância e comportamento, o início do século XX foi um período decisivo, tendo como ícone a figura de Sigmund Freud (1856-1939). Mesmo antes da publicação de $A$ interpretação dos sonhos (1900), obra na qual o autor afirma ser a experiência da infância "uma das fontes de onde os sonhos retiram material para reprodução" (FREUD, 1980, p. 22), Freud já havia descoberto o significativo papel desse período da vida na elaboração do psiquismo, explorando experiências da memória de seus pacientes para o estudo de doenças psíquicas (ZAVARONI et al., 2007).

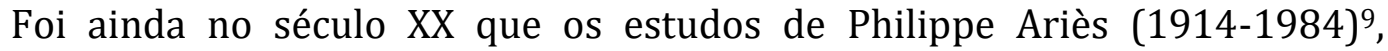
historiador e sociólogo francês, ganham notoriedade em seu tratado História social da criança e da família (L'enfant et la vie familiale sous l'Ancien Régime, 1960) e possibilitam discussões acerca das diferentes concepções de infância construídas ao longo da história, engendrando uma ideia de infância que se amolda de forma distinta e característica a cada período vivido ou de acordo com cada sociedade analisada.

No Brasil, a história da infância mistura-se à "infância" do próprio país. No prefácio à primeira edição de Sobrados e Mucambos (1936), em que o autor de CasaGrande e senzala (1933) propõe a continuidade do trabalho de pesquisa sociológica

9 Philippe Ariès (1914-1984). Historiador e medievalista francês da família e infância. Sobre os estudos de Ariès voltaremos no Capítulo 1 desta tese. 
iniciado três anos antes, Gilberto Freyre ${ }^{10}$ afirma ser seu segundo livro uma "tentativa de reconstituição e de interpretação de certos aspectos mais íntimos da história social da família brasileira". Em ambas as obras, além de destacar a proeminente questão entre raças, herança de uma sociedade patriarcal e escravocrata, o autor revela também particularidades das relações entre pai e filho, homem e mulher, adulto e criança, senhores e crias da casa, ajudando a construir uma imagem da família brasileira em um período em que a criança e suas necessidades ainda ocupavam um lugar bastante secundário.

Também visando sistematizar estudos sobre uma "história social" da família e, mais especificamente, da infância no Brasil, Marcos Cezar de Freitas ${ }^{11}$ organizou uma obra coletiva em que procurou registrar e discutir algumas "imagens que se cristalizaram historicamente sobre a infância" (2011, p. 13, grifo do autor), recorrendo a especialistas de várias áreas do conhecimento para oferecer "aos estudiosos da infância no Brasil uma cartografia das representações sobre a criança, trazendo ao debate interlocutores de diversas matrizes investigativas [...]" (2011, p. 14). Dois dos capítulos que compõem essa rede de conceitos e imagens e envolvem esse "rastreamento da história da infância" são destinados ao importante papel da literatura nas representações sociais: o ensaio "Infância de papel e tinta”, escrito por Marisa Lajolo, que reúne análises da criança como personagem em romances, contos e poemas, e o capítulo "A infância no Brasil pelos olhos de Monteiro Lobato", de Ivan Russeff, no qual o autor faz suas considerações acerca do "legado" deixado pelo criador do Sítio do Picapau Amarelo "às concepções educacionais e estéticas sobre a criança brasileira" (2011, p. 14).

Ao agregar as "expressões literárias sobre a criança" às áreas do saber intimamente ligadas à historiografia como fontes de pesquisa para se traçar uma história da infância no Brasil, Freitas atribui à literatura um papel de relevo capaz de "captar imagens" e fornecer "diagnósticos" sobre o tema (2011, p. 13-14).

\footnotetext{
10 Gilberto Freyre (1900-1987), autor do célebre Casa-grande \& senzala (1933), entre outras importantes obras. Sociólogo, escritor, ensaísta e também poeta, desenhista e pintor. Em sua principal obra ele propõe uma "interpretação do Brasil” por meio de um olhar diferenciado sobre o negro e sobre o índio, o que lhe valeu uma série de críticas por "falta de cientificidade em sua obra". Embora não seja uma unanimidade, Freyre ainda hoje é considerado um dos mais importantes sociólogos do século XX. Estudos de Gilberto Freyre serão retomados ao longo da tese, especialmente no Capítulo 3.

11 Coordenador do Programa de Pós-Graduação Educação e Saúde na Infância e na Adolescência, onde dirige o LEVI: Laboratório de Estudos de Vulnerabilidades Infantis.
} 
Também a historiadora Diane Valdez ${ }^{12}$ atribui às representações literárias papel de destaque no estudo do passado. Para a autora, "a história e o passado são plurais", isto é, configuram

um conjunto de valores construídos, socializados, significados e legitimados pelos homens para explicar um tempo e uma sociedade. Desta forma, para compreender um tempo, uma época e uma sociedade, faz-se necessário compreender suas representações, que em cada época são construídas para conferir e dar sentido ao real (VALDEZ, 2006, p. 16).

Desse modo, assim como a arte iconográfica traduziu-se em valioso recurso para Philippe Ariès desenvolver sua pesquisa acerca das representações da infância nos séculos anteriores à Idade Moderna, também a arte da escrita pode configurar importante campo de estudo para se tentar compreender a concepção de infância de uma determinada época e lugar, por meio da análise dessas crianças de "papel e tinta" que habitam páginas de romances, novelas, contos e poemas, e cujas infâncias estão retratadas e sedimentadas nas narrativas e nos versos construídos pelas penas de seus autores.

Para Gilberto Freyre,

a literatura e a arte não pertencem apenas ao domínio da crítica literária ou de arte: incidem também no domínio do sociólogo, do historiador social, do antropólogo e do psicólogo social. Porque através da literatura e da arte é que os homens parecem mais projetar a sua personalidade, e, através da personalidade, o seu éthos nacional. Através das artes eles descrevem as condições mais angustiantes do meio em que vivem e refletem os seus desejos mais revolucionários. E ainda, através das artes, exprimem os aspectos mais particularmente oprimidos, tanto como os mais vigorosamente dinâmicos, da sua personalidade e do seu éthos nacional (FREYRE, 2015, p. 183).

12 Diane Valdez. Historiadora com mestrado em História pela UFG e doutorado em Educação pela UNICAMP. Professora da Faculdade de Educação da UFG. 
Já para o sociólogo e pesquisador Cauby Dantas ${ }^{13}$, "refletir sobre a interpenetração literatura-sociedade" pressupõe "tentar relacionar textos e contextos, buscar surpreender a ocorrência dos aspectos sociais nas obras literárias e os níveis desta correlação". Para o autor,

a literatura é uma forma de expressão artística que, pela transcendência e transfiguração, favorece a compreensão de realidades e cotidianos sociais, o que não oblitera suas intenções estéticas, expressas pela capacidade inventiva dos autores, na busca do belo e, também, nas emoções e sentimentos e mobilizações eventualmente desencadeados pelas representações literárias (DANTAS, 2015, p. 28-29).

Acerca dessa interpenetração literatura-sociedade, em um de seus estudos críticos, Antonio Candido ${ }^{14}$ estabelece algumas modalidades de investigação sociológica em literatura, entre as quais aquela baseada em dados que procuram verificar "em que medida a arte é expressão da sociedade" (CANDIDO, 1967, p. 25). Durante suas considerações, o autor alerta sobre o fato de ser a arte "eminentemente, comunicação expressiva", isto é, "expressão de realidades profundamente radicadas no artista, mais que transmissão de noções e conceitos". E complementa lembrando que, justamente por se tratar de "uma comunicação expressiva, a arte pressupõe algo diferente e mais amplo do que as vivências do artista" (p. 26). Assim, de acordo com Candido, "a arte é [...] um sistema simbólico de comunicação inter-humana", presumindo "o jogo permanente de relações" entre obra, autor e público, formando uma "tríade indissolúvel” (p. 43). Para concluir, cita Thomas Pollock, para quem a invenção da escrita "tornou possível a um ser humano criar num dado tempo e lugar uma série de sinais, a que pode reagir outro ser humano, noutro tempo e lugar" (POLLOCK, 1942 apud CANDIDO, 1967, p. 44).

É importante lembrar os dizeres de Candido, porém, de que a literatura, por mais realista que possa parecer, pode até ser vista como "espelho da sociedade",

\footnotetext{
${ }^{13}$ Cauby Dantas. Professor assistente da Universidade Federal da Paraíba.

${ }^{14}$ Antonio Candido (1918-2017). Sociólogo, literato, crítico literário e professor emérito da USP e UNICAMP.
} 
refratando-a e refletindo-a, sem, contudo, afastar o caráter deformador que todo espelho apresenta. Segundo o crítico, é preciso "ter consciência da relação arbitrária e deformante que o trabalho artístico estabelece com a realidade, mesmo quando pretende observá-la e transpô-la rigorosamente, pois a mimese é sempre uma forma de poiese" (CANDIDO, 1967, p. 14).

Desse modo, a liberdade criativa do autor

é o quinhão da fantasia, que às vezes precisa modificar a ordem do mundo justamente para torná-la mais expressiva; de tal maneira que o sentimento da verdade se constitui no leitor graças a esta traição metódica. Tal paradoxo está no cerne do trabalho literário e garante a sua eficácia como representação do mundo (CANDIDO, 1967, p. 14).

Sendo assim, para Candido a obra literária "não é produto fixo, unívoco ante qualquer público; nem este é passivo, homogêneo, registrando uniformemente o seu efeito"; pelo contrário. De acordo com o autor, a literatura é

um sistema vivo de obras, agindo umas sobre as outras e sobre os leitores; e só vive na medida em que estes a vivem, decifrando-a, aceitando-a, deformando-a" (CANDIDO, 1967, p. 86).

Feitas essas primeiras considerações, passemos à explicitação do projeto de pesquisa que gerou o presente trabalho.

Considerando-se o fato de que nem sempre a infância foi alvo de representações literárias, como será discutido no Capítulo I desta tese, e que isso só veio ocorrer de fato com mais consistência a partir de meados do século XIX, na Europa, e do início do século seguinte, no Brasil, nossa proposta foi analisar algumas obras 
significativas da literatura brasileira, provenientes desse período - a primeira metade do século XX -, que trazem crianças como protagonistas.

O objetivo da pesquisa é tentar resgatar imagens da infância ali representadas, promovendo um diálogo entre elas, no intuito de estabelecer relações entre as tramas, os personagens, a temática e o contexto social retratado em cada obra. Além disso, considerando-se os estudos sociológicos de Gilberto Freyre ${ }^{15}$ acerca da constituição das relações sociais e da família brasileira que vigorou no Brasil nos séculos anteriores ao período estudado, tivemos também como interesse buscar nos textos de ficção traços da infância descrita pelo sociólogo, que trazem em sua bagagem a herança de séculos passados, vestígios de uma sociedade patriarcal e escravocrata.

O período escolhido para a pesquisa está compreendido entre 1920 e 1945, época marcada por importantes e profundas transformações, não somente na sociedade brasileira, mas em todo o mundo. Os impactos causados pelas duas grandes guerras mundiais ${ }^{16}$, o crescimento da indústria, a expansão das comunicações e o surgimento de novas potências mundiais foram alguns dos fatores determinantes evidenciados no início do século XX, tanto no Velho Continente como na América.

No Brasil, esse intervalo de tempo caracterizou-se por alterações de rumo na política, na economia, na educação, na sociedade e, consequentemente, também nas artes. A Semana de Arte Moderna determinou o início de um movimento de ruptura que viria a ficar conhecido pela quebra de paradigmas e de alargamento de fronteiras, envolvendo liberdade de criação e expressão e busca pela identidade nacional literária e artística como alternativa aos modelos europeus, mobilizando uma série de intelectuais e artistas.

Para Candido \& Castello ${ }^{17}$, em seu panorama histórico sobre a literatura brasileira18, o Movimento Modernista causou uma "transformação literária" que "visava sobretudo a orientar e definir uma renovação, formulando em novos termos o conceito de literatura e de escritor" (1968, p. 7). Assim, de acordo com os autores,

\footnotetext{
15 Para o propósito desta tese nos ateremos às obras Casa-Grande e Senzala (1933) e Sobrados e Mucambos (1936).

16 Primeira Guerra Mundial, de 1914 a 1918; Segunda Guerra Mundial, de 1939 a 1945.

17 Antonio Candido (1918-2017); José Aderaldo Castello (1921-2011).

18 CANDIDO \& CASTELLO. Presença da Literatura Brasileira. Vol. III - Modernismo. 3. ed. São Paulo, Difusão Europeia do Livro, 1968.
} 
1922 é um ano simbólico do Brasil moderno, coincidindo com o Centenário da Independência. A Guerra Mundial de 1914-1918 influiu no crescimento da nossa indústria e no conjunto da economia, assim como nos costumes e nas relações políticas. Não apenas surge uma mentalidade renovadora na educação e nas artes, como se principia a questionar seriamente a legitimidade do sistema político, dominado pela oligarquia rural. Torna-se visível, principalmente nos Estados do Sul, que dominam a vida econômica e política, a influência da grande leva de imigrantes, que forneceram mão de obra e quadros técnicos depois de 1890, trazendo elementos novos do panorama material e espiritual (CANDIDO \& CASTELLO, 1968, p. 7-8).

Ainda de acordo com Candido \& Castello, "seja tomado como movimento renovador, seja como nova estética [...], o Modernismo revela, no seu ritmo histórico, uma adesão profunda aos problemas da nossa terra e da nossa história contemporânea". Assim, "nenhum outro momento da literatura brasileira é tão vivo sob este aspecto; nenhum outro reflete com tamanha fidelidade, e ao mesmo tempo com tanta liberdade criadora, os movimentos da alma nacional" (CANDIDO \& CASTELLO, 1968, p. 9).

O período estabelecido para nosso estudo coincide com a duração do movimento modernista, considerando-se os "sinais precursores" da Semana de Arte Moderna que, a partir de 1920, "se tornam cada vez mais conscientes e planejados" (p.11), e o final da sua fase dinâmica, que se prolongaria até o ano de 1945. Para os críticos, os últimos anos desse período (1930-1945) foram marcados não somente pelo "grande surto do romance, tão brilhante quanto o que se verificou entre 1890 e 1910" (p. 26), como pelo aparecimento dos estudos históricos e sociais "que passam por acentuada renovação, focalizando com intensidade crítica a realidade do País", pela importância que assume a esfera artística e pela expansão do mercado editorial brasileiro, que finda com a "dependência de firmas estrangeiras" (CANDIDO \& CASTELLO, 1968, p. 29).

Outra "coincidência" desse período delimitado para o estudo e que merece ser destacada está no fato de esse intervalo de tempo (1920-1945) apresentar uma 
sincronia perfeita com o ciclo de publicações das obras infantis de Monteiro Lobato ${ }^{19}$, que mudou o panorama nacional no que se refere à história da literatura infantil brasileira, tornando-se um "divisor de águas" 20 para o gênero: o que havia antes da publicação de Lobato eram algumas traduções e tentativas de se resgatarem histórias populares (especialmente com Figueiredo Pimentel), algumas obras de cunho didático ${ }^{21}$ e contos exemplares.

Para Marisa Lajolo \& Regina Zilberman²2,

entre estes dois limites cronológicos, 1920-1945, toma corpo a produção literária para crianças, aumentando o número de obras, o volume das edições, bem como o interesse das editoras, algumas delas [...] dedicadas quase que exclusivamente ao mercado constituído pela infância (LAJOLO \& ZILBERAMAN, 1999, p. 46).

Monteiro Lobato surge como uma possibilidade real de se criar algo novo para a criança brasileira, afastando-se dos modelos europeus e criando uma narrativa capaz de contar histórias da nossa terra, que despertasse o interesse da criança sem o ufanismo e o patriotismo exaltado em obras precedentes. Desde 1920, com o surgimento de A menina do narizinho arrebitado até sua última publicação infantil, datada de 1944 (Os doze trabalhos de Hércules), foram dezenas de títulos, entre criações originais e adaptações, que encantaram crianças de várias gerações. Para Nelly Novaes Coelho ${ }^{23}$, Lobato "rompe, pela raiz, com as convenções estereotipadas e abre as portas para as novas ideias e formas que o nosso século exigia" (COELHO, 1991, p. 225). Para a autora, a obra lobatiana revela entre seus maiores atributos novas tendências na interação entre crianças e adultos, "relações baseadas na afeição mútua e na harmonia", "livres do

\footnotetext{
${ }^{19}$ Monteiro Lobato (1882-1948). A primeira obra de Lobato publicada para crianças é datada de 1920.

20 "Divisor de águas" é expressão usada por Nelly Novaes Coelho para designar a importância de Monteiro Lobato para a Literatura Infantil Brasileira (COELHO, 1991, p. 225).

${ }^{21}$ Podemos citar como exemplos as Histórias da nossa terra, de Júlia Lopes de Almeida (1907), Através do Brasil, de Olavo Bilac e Manuel Bonfim (1910) e Saudade, de Tales de Andrade (1919).

22 Marisa Lajolo, pesquisadora, crítica literária, autora e professora universitária, coordenadora do projeto Memória da Leitura (UNICAMP). Regina Zilberman (1948), escritora e pesquisadora brasileira, estudiosa da história da literatura e autora de diversos livros e ensaios sobre literatura infantil.

${ }^{23}$ Nelly Novaes Coelho, estudiosa da literatura infantil, autora e ensaísta. Pesquisadora e crítica literária, criou em 1980, na área de Letras da USP, a disciplina de literatura infantil.
} 
tradicional condicionamento exemplar a ser assimilado pelos pequenos" (COELHO, 1995, p. 849).

Em contrapartida, vêm a público nesse mesmo período (1920-1945) importantes obras da literatura brasileira que apresentam a infância de forma bastante diversa daquela idealizada nas narrativas infantis de Lobato, mostrando a dura realidade da criança brasileira nesses anos de transformação. Essas narrativas que se consolidaram ao longo do tempo como obras de referência na literatura nacional trouxeram à tona, no campo da ficção ${ }^{24}$, diferentes aspectos da infância, como a relação da criança com a família, com a escola, com a dor dos castigos físicos, com a descoberta da sexualidade, com a aquisição de conhecimentos que não se limitavam ao aprendizado formal, entre outros.

Assim, a hipótese que levantamos, tomando como base o período escolhido e as obras estudadas, é a de que a infância representada na literatura brasileira na primeira metade do século XX traz em sua bagagem a herança de séculos passados, e expõe, através do olhar infantil, as dificuldades de ser criança naquela época, entre as quais, a exposição precoce ao sexo; a falta de materiais e métodos apropriados para o aprendizado da leitura; as humilhações, os castigos físicos, e os maus tratos a que eram submetidas, entre outras.

As obras escolhidas para compor o corpus da pesquisa tiveram como base os seguintes critérios: terem sido publicadas no intervalo de tempo estabelecido (19201945); apresentarem como protagonistas personagens infantis, sem, contudo, configurar obra infantil (escrita intencionalmente para a criança); trazerem elementos para a análise que favorecessem um diálogo entre elas, como a caracterização da época e do lugar em que a trama se passa, a presença de personagens adultos que pudessem fazer uma contraposição com a infância na obra; além de retratarem experiências dos personagens, como o aprendizado e o crescimento vinculado à passagem do tempo na narrativa. Assim, selecionamos para o estudo um conto e três romances, que serão analisados um a um, obedecendo à ordem cronológica em que foram publicados, e, em seguida, elaboraremos nossas conclusões.

\footnotetext{
${ }^{24}$ Embora entre as obras estudadas exista um caráter autobiográfico em pelo menos duas delas, por se
} tratarem de romances e, desse modo, de obras de arte, vamos tratá-las todas como obras de ficção. 
A análise de "Negrinha” (1920), de Monteiro Lobato (1882-1948), é o ponto de partida para nossa pesquisa, evidenciando um Lobato ainda não dedicado à construção do seu maior legado, os livros que integram a coleção do "Sítio do Picapau Amarelo", mas já pioneiro no sentido de criar uma obra essencialmente brasileira. Nascido no mesmo ano em que se tornava pública pela primeira vez a Menina do Narizinho Arrebitado, o conto "Negrinha" mostra, ao contrário do universo idílico e fantástico do Sítio de Dona Benta, o cotidiano realista e cruel de uma criança órfã e negra, vivendo "de favor" na casa grande, nos anos que sucederam a abolição. A partir da análise desta obra, é possível estabelecer alguns pontos de comparação com o universo infantil de Lobato, e também com os romances que viriam aflorar na década seguinte, trazendo meninos como protagonistas.

A segunda obra estudada, Menino de engenho (1932), romance de estreia de José Lins do Rego (1901-1957) na literatura, é publicada dez anos após a Semana de 22, quando o Modernismo já entrava em sua fase de maturação, com destaque para a prosa regionalista nordestina que inovava tanto no estilo e na linguagem como nos temas abordados, revelando uma renovação do Naturalismo. No romance, José Lins dá voz ao personagem Carlinhos, contando a infância do protagonista em caráter intimista, em primeira pessoa, relatando os anos em que o menino viveu no engenho do avô, dos quatro aos doze anos de idade.

Capitães da Areia (1937), um dos livros mais populares de Jorge Amado (19122001), é a terceira obra analisada nesta tese, e a única que não traz apenas um protagonista - como as demais -, mas um grupo de crianças e adolescentes que vivem de pequenos furtos nas ruas e becos da cidade da Bahia. No romance, o escritor baiano apresenta ao leitor a rotina desse bando de "crianças ladronas", trazendo a público o problema do menor abandonado por meio das aventuras e dos sonhos desses meninos, ora crianças, ora bandidos.

Por fim, no último capítulo da tese, analisaremos alguns excertos do livro Infância (1945), de Graciliano Ramos (1892-1953), em que o autor relata cenas do cotidiano de uma criança e suas descobertas a respeito do mundo que a cerca por meio de fragmentos de sua memória.

Porém, antes de iniciar a análise propriamente dita dos textos que fazem parte do corpus desta tese, teceremos algumas considerações preliminares a respeito da 
infância e do período em que as obras se inserem. "A infância na narrativa literária" é o tema do primeiro capítulo, em que discutiremos alguns conceitos sobre literatura e infância, e situaremos as obras escolhidas dentro do cenário literário do início do século $\mathrm{XX}$, nesse intervalo de tempo caracterizado pela proliferação de obras sobre e para a criança brasileira.

Nesse sentido, é interessante notar que, apesar de a literatura infantil não ter sido o escopo deste trabalho, e nem este tenha sido um critério de inclusão em nosso corpus, todos os autores analisados - em algum momento de sua carreira literária dedicaram-se a escrever também para a infância. Assim, além de Monteiro Lobato, cuja obra infantil é vastamente conhecida, também escreveram livros infantis José Lins do Rego (Histórias da Velha Totônia, 1936), Jorge Amado (O gato malhado e a andorinha Sinhá, 1976; A bola e o goleiro, 1984; A Ratinha Branca de Pé-de-vento e a Bagagem de Otália, 2009), e Graciliano Ramos (A Terra dos Meninos Pelados, 1939, Histórias de Alexandre, 1944, Alexandre e Outros Heróis, 1962, o Estribo de Prata, 1984, Minsk, 2013).

Para Mary Del Priore, ao questionar o lugar da criança na atual sociedade, o "saudável exercício" de "olhar para trás" ajuda a "iluminar os caminhos que agora percorremos" (2013, p. 8). Segundo a autora,

o estudo das representações ou das práticas infantis é considerado tão importante que a historiografia internacional já acumulou consideráveis informações sobre a criança e seu passado (DEL PRIORE, 2013, p. 9).

Embora no trecho acima a autora se refira especificamente à historiografia, resgatar do passado algumas representações infantis em obras literárias pertencentes a uma mesma época e contexto sociopolítico permite-nos estabelecer paralelos entre as diferentes concepções de infância forjadas pelos autores analisados, tomando como base um período marcado pela ruptura e quebra de paradigmas, em que havia terreno propício e fértil para a exploração de novas abordagens. 
0 poema de Carlos Drummond de Andrade, "Infância"25, escolhido como epígrafe desta tese, é uma homenagem a todos os autores que se propuseram a escrever sobre esse período da vida, e traduz, de certa forma, o olhar do poeta para a criança que habita em sua memória. Escrever sobre a infância, como lembramos, é poder voltar os olhos para a criança que fomos um dia, e que vive, ainda que de forma latente, dentro de nós.

Del Priore conclui a introdução à sua obra coletiva sobre a história das crianças no Brasil afirmando que "querer conhecer mais sobre a trajetória histórica dos comportamentos, das formas de ser e de pensar das nossas crianças, é também uma forma de amá-las todas, indistintamente melhor" (2013, p. 17).

É o que almejamos com o presente trabalho.

25 “Infância” é o segundo poema do livro de estreia de Carlos Drummond de Andrade, Alguma Poesia, 1930. 
"A infância não é um tempo, não é uma idade, uma coleção de memórias. A infância é quando não é demasiado tarde. É quando estamos disponíveis para nos surpreendermos, para nos deixarmos encantar. [...] É uma janela que, fechada ou aberta, permanece viva dentro de nós". 
Capítulo 1

A infância na narrativa literária 


\section{CAPÍTULO 1}

\section{A infância na narrativa literária}

"A criança que habita romances e poemas é parente muito próxima da criança que, em outdoors, vende sabonetes ou planos de saúde, da outra criança que é objeto de recomendações da UNESCO e também daquela outra que inspira pedagogias e puericulturas".

Marisa Lajolo26

\subsection{Considerações iniciais}

Definida como o "período do desenvolvimento do ser humano, que vai do nascimento ao início da adolescência"27, a infância tem sido, ao longo do tempo, alvo de pesquisa de diferentes áreas do conhecimento. Mais do que uma definição, porém, o termo requer algumas considerações, uma vez que, antes de entrarmos no campo das representações da infância na literatura, é preciso estabelecer alguns parâmetros para esclarecer a "que infância" estamos nos referindo.

A epígrafe que abre este primeiro capítulo, de autoria de Marisa Lajolo, é retirada de uma obra coletiva, o livro História social da infância no Brasil, organizado por Marcos Cezar de Freitas, cujo propósito principal consistiu em sistematizar, registrar e discutir algumas "imagens que se cristalizaram historicamente sobre a infância" (FREITAS, 2011, p. 13, grifo do autor).

\footnotetext{
${ }^{26}$ LAJOLO, M. "Infância de papel e tinta” In: FREITAS, M. C. (org.). História social da infância no Brasil. 8.ed. São Paulo, Cortez, 2011, p. 232.

27 Fonte: Dicionário Houaiss eletrônico.
} 
Sabemos que a simples menção da palavra "infância" nos remete a uma "imagem" que, dependendo da época e do lugar, pode variar significativamente, em especial quando se consideram os aspectos sociais e historiográficos em que o período e o momento se inserem. Por esse motivo, o tema requer um recorte preciso, tanto espacial como temporal.

De acordo com Freitas, em outra obra coletiva dedicada ao estudo da história da infância ${ }^{28}$ a duração desse período é um "elemento variável". Segundo ele, esse espaço de tempo

pode se restringir aos primeiros 12 ou 18 meses - a infância, depois a puerícia etc. Ou então ao período que se estende até completar 7 anos, a idade da razão [...]. Ou ainda pode durar até os 10, 12 ou 14 anos como na análise de Ariès sobre o prolongamento da infância, com a criação dos colégios onde as crianças ficariam separadas do mundo dos adultos (FREITAS, 2002, p. 7).

Já para Lajolo, a fim de que se instaure uma "precisão cada vez maior" a respeito dessa definição, existe uma "constante necessidade de recorte e afinação", uma vez que, segundo ela, a infância está entre as categorias que "só vigem no espaço social em que são estabelecidas, negociadas, desestabilizadas e reconstruídas" (LAJOLO, 2011, p. 230). Assim, nos dizeres da autora,

muito embora os seres humanos tenham sempre nascido frágeis, pequeninos e leves e - quando sobrevivem... - tenham sempre ganhado altura e peso ao longo de muitos anos até que ficam fortes e seu tamanho se estabiliza, e seja sua idade contada por anos, por luas, ou por chuvas, o significado de ser um ser humano deste ou daquele tamanho, com muita ou com pouca altura, varia enormemente de um lugar para outro, de um tempo para outro (LAJOLO, 2011, p. 230).

${ }^{28}$ FREITAS, M. C. Os intelectuais na história da infância. São Paulo, Cortez, 2002. 
Em busca de outras possibilidades de sentido para o termo, Lajolo recorre a fontes provenientes de outras línguas, encontrando o verbete "infanzia" no Vocabolario della lingua italiana, enunciado como o período que abrange "dalla nascita ai dodici anni" (do nascimento até os doze anos), e infancy, no Webster, definido como early childhood (primeira infância) (LAJOLO, 2011, p. 231).

Como áreas do conhecimento responsáveis por apresentar diferentes "formulações" sobre a infância, a autora elege a psicologia, a biologia, a psicanálise e a pedagogia, afirmando ser o conjunto de ideias e crenças que se estabeleceu sobre a infância com o passar do tempo uma "divertida ciranda de contradições" (p. 232). A autora conclui afirmando que "por isso mesmo, percebe-se, não é a mesma coisa, aqui e lá, ontem e hoje, sendo tantas infâncias quantas forem ideias, práticas e discursos que em torno dela e sobre ela se organizem" (p. 231).

Para Neil Postman"29, autor do livro $O$ desaparecimento da infância, "passado o primeiro ano de vida, a infância é um artefato social, não uma categoria biológica". Segundo ele, "nossos genes não contêm instruções claras sobre quem é e quem não é criança, e as leis de sobrevivência não exigem que se faça distinção entre o mundo do adulto e o da criança". Em seguida, o autor define o termo "crianças" (children) como "uma classe especial de pessoas situadas entre sete e, digamos, dezessete anos, que requerem formas especiais de criação e proteção e que se acredita serem qualitativamente diferentes dos adultos" (POSTMAN, 2008, p. 11). E ainda atribui a "ideia de infância" (childhood) como "uma das grandes invenções da Renascença", no século XVI.

Desse modo, tanto para Freitas, como para Lajolo ou para Postman, mais do que uma "fase da vida", o termo "infância" comportaria uma "ideia" ou uma "concepção" construída histórica e socialmente, e para a qual existem inúmeras imagens correlatas, dependendo da época ou do local em que se pretende estabelecer as bases para uma pesquisa.

\footnotetext{
${ }^{29}$ Neil Postman (1931-2003). Educador, teórico da comunicação e crítico social americano no século XX. Autor de vários livros importantes, entre eles, $O$ desaparecimento da infância (The disappearance of childhood, 1982).
} 
Essa "ideia de infância" é especialmente explorada e apresentada em pormenores nos estudos de Philippe Ariès ${ }^{30}$, em seu tratado História social da criança e da família (L'enfant et la vie familiale sous l'Ancien Régime, 1960). De acordo com o historiador francês, "na sociedade medieval [...], o sentimento de infância não existia". Ariès define esse "sentimento" como uma "consciência da particularidade infantil [...] que distingue essencialmente a criança do adulto, mesmo jovem" (ARIÈS, 1981, p. 156). Assim, segundo ele, a partir do momento em que a criança já não exigia da mãe ou da ama os constantes cuidados de que carecem naturalmente os bebês, ela estaria apta a ingressar na sociedade dos adultos, "e não se distinguia mais destes" (p. 156). Ariès afirma ainda que, "até o século XVIII, a adolescência foi confundida com a infância" (p. 41) e que "durante muito tempo, no século XVI e até mesmo no século XVII, essa relação foi muito incerta" (p. 177).

Analisando especialmente a iconografia como representação da sociedade desde a Idade Média, Ariès aponta o surgimento do "sentimento de família”, nos séculos XVI e XVII, como um dos fatores significativos para se entender as mudanças com relação às concepções de infância que se tinha até então, afirmando que "a família transformou-se profundamente na medida em que modificou suas relações internas com a criança" (p. 225). De acordo com o autor, outro fato relevante para corroborar essa ideia foi a substituição do aprendizado informal a que as crianças eram submetidas até o século XV pelo aprendizado formal, que se deu gradualmente por meio da escola, proporcionando uma "evolução paralela do sentimento das idades e da infância" (ARIÈS, 1981, p. 170). Assim, por volta do século XV e, sobretudo, no XVI, o colégio tornou-se

uma instituição essencial da sociedade: o colégio com um corpo docente separado, com uma disciplina rigorosa, com classes numerosas, em que se formariam todas as gerações instruídas do Ancien Régime. 0 colégio constituía, se não na realidade mais incontrolável da existência, ao menos na opinião mais racional dos educadores, pais, religiosos e magistrados, um grupo de idade maciço, que reunia alunos de oito-nove anos até mais de 15, submetidos a uma lei diferente da que governava os adultos (ARIÈS, 1981, p. 171).

30 Philippe Ariès (1914-1984). Historiador francês dedicado aos estudos da infância e da família. 
Postman ratifica a importância da escola na "evolução do conceito de infância”. Para ele, "onde a instrução foi sempre altamente valorizada, havia escolas, e, onde havia escolas, o conceito de infância desenvolveu-se rapidamente" (POSTMAN, 2008, p. 53). E complementa afirmando que, "como a escola se destinava a formar adultos instruídos, os jovens passaram a ser vistos não mais como miniaturas de adultos, mas como algo completamente diferente: adultos ainda não formados" (p. 53). Porém, além da escola, o autor atribui à invenção da prensa tipográfica, no século XV, um papel decisivo na mudança de postura da vida em sociedade, o que teria ocasionado, consequentemente, uma cisão entre o mundo adulto e o infantil, engendrando uma nova concepção de infância. Segundo ele, durante a Idade Média, "houve várias mudanças sociais, algumas invenções importantes [...] e muitos acontecimentos notáveis [...]". Contudo, "não ocorreu nada que exigisse que os adultos alterassem sua concepção da própria vida adulta”. No decorrer do século XV, porém, um acontecimento significativo "se verificou: a invenção da impressão com caracteres móveis" (p. 34). De acordo com Postman,

a tipografia criou um novo mundo simbólico que exigiu, por sua vez, uma nova concepção de idade adulta. A nova idade adulta, por definição, excluiu as crianças. E como as crianças foram expulsas do mundo adulto, tornou-se necessário encontrar um outro mundo que elas pudessem habitar. Este outro mundo veio a ser conhecido como infância (POSTMAN, 2008, p. 34).

0 autor justifica suas considerações atribuindo à invenção da prensa a mudança de comportamento de toda a sociedade, quando atividades de escrita e leitura abriram espaço para o individualismo. Assim, a "explosão do conhecimento" passou a se dar de modo mais eficaz e veloz, por meio da disseminação de obras impressas (livros e jornais), e se estabeleceram duas novas categorias de pessoas: aquelas que tinham acesso à informação e ao conhecimento (leitores) e aquelas que não sabiam ler (crianças ou pessoas não alfabetizadas). 
Ainda de acordo com Postman, "a tipografia incrementou enormemente a comunicação entre os cientistas em escala continental" e popularizou as ideias científicas por meio da escrita", tornando a ciência um "assunto público" e não mais exclusivo dos alquimistas. Textos clássicos ganharam versões impressas e puderam ser acessados por todos aqueles que soubessem ler. Deste modo Postman termina sua teoria:

\footnotetext{
O que aconteceu, simplesmente, foi que o Homem-Letrado tinha sido criado. E ao chegar, deixou para trás as crianças. Pois, no mundo medieval, nem os jovens nem os velhos sabiam ler e seu interesse era o aqui e agora [...]. Não havia necessidade da ideia de infância porque todos compartilhavam o mesmo ambiente informacional e, portanto, viviam no mesmo mundo social e intelectual. Mas, quando a prensa tipográfica fez a sua jogada, tornou-se evidente que uma nova espécie de idade adulta tinha sido inventada. A partir daí a idade adulta tinha de ser conquistada. Tornou-se uma realização simbólica e não biológica. Depois da prensa tipográfica, os jovens teriam de se tornar adultos e, para isso, teriam de aprender a ler, entrar no mundo da tipografia. E para realizar isso precisariam de educação (POSTMAN, 2008, p. 50).
}

Entre os estudos de Ariès e os de Postman há um interessante fato a se notar: enquanto o primeiro faz uma espécie de percurso histórico para exemplificar o que poderíamos chamar de "nascimento da infância", mostrando como a diferenciação entre a criança e o adulto foi sendo estabelecida ao longo dos séculos, a partir da Idade Média, Postman propõe um movimento inverso: inicia sua análise resgatando os estudos de Ariès e de outros historiadores - e dando suas próprias contribuições para exemplificar e justificar o que ele mesmo chama de "invenção da infância" -, e, a partir daí, procura mostrar como, no século XX, esse "sentimento" ou "ideia" de infância começa a desaparecer, sendo cada vez mais possível observar crianças e adultos compartilhando o mesmo mundo, seja por meio da erotização precoce, do trabalho infantil ou das próprias atividades que atraem um e outro, indiscriminadamente, como, por exemplo, as vestimentas modernas e o interesse pelos jogos computadorizados (videogames). 
Desse modo, embora a historiografia não seja objeto de estudo desta tese, entendemos que a obra de Ariès, com o pioneirismo com que tratou o tema, e os trabalhos posteriores de Postman são textos que se complementam, e podem clarificar essa ideia de que as concepções de infância se transformam ao longo do tempo e do espaço, de acordo com a época e com o local estudado.

\subsection{Literatura e infância: uma via de mão dupla}

O diálogo entre infância e literatura pode ser compreendido de duas maneiras distintas: de um lado, temos as crianças que "habitam" as páginas de romances, novelas, contos e poemas, isto é, textos líricos, ficcionais ou autobiográficos em que a infância é, de alguma forma, representada; de outro, temos um conjunto de obras concebidas ou adaptadas para a criança, formando um repertório literário conhecido como literatura infantil e juvenil. Assim, embora nossos esforços nesta pesquisa estejam voltados a estudar a primeira, isto é, a infância representada na narrativa literária, não podemos deixar de citar a segunda, uma vez que esses caminhos por vezes se cruzam e se sobrepõem, tomando o caso da literatura que fala sobre e para a criança ao mesmo tempo.

Também não é propósito deste trabalho discutir as origens da literatura infantil, assunto já exaustivamente debatido por críticos e pesquisadores da área, porém nos valeremos de alguns estudos para mostrar que, do mesmo modo como ocorreu na sociedade, também na história da literatura a infância tardou a ganhar um papel de destaque.

Em ampla análise sobre a gênese da literatura infantil brasileira, Leonardo Arroyo $^{31}$ refere-se aos séculos XVII e XVIII como fundamentais para o desenvolvimento

\footnotetext{
${ }^{31}$ Leonardo Arroyo (1918-1986). Jornalista, ensaísta, autor de livros infantis e poeta. Seu livro Literatura
} infantil brasileira é original de 1968. 
do gênero na Europa, período marcado pelo surgimento de autores que, de modo pioneiro, se preocuparam em escrever para a infância. Cita como exemplo maior dessa época o escritor francês Charles Perrault (1628-1703), definido pelo crítico como o responsável por romper "com o preconceito mantido em torno da cultura popular e em torno da criança" (ARROYO, 2011, p. 20-21), tornando possível o aparecimento de outros nomes importantes, tanto na França, como, por exemplo, Madame Jeanne-Marie Leprince de Beaumont ${ }^{32}$, quanto na Inglaterra, como John Newberry ${ }^{33}$. Para Arroyo, mesmo obras que não teriam surgido inicialmente para a criança, como Robinson Crusoe (1719) ${ }^{34}$ e As viagens de Gulliver (1726), por exemplo, acabaram sendo "adotadas" pelo público infantil, vindo "ao encontro de uma necessidade universal de leitura" devido ao seu conteúdo aventureiro e aos elementos reais da vida que as narrativas contêm (ARROYO, 2011, p. 21).

E apesar de atribuir importância ao século XVIII para o nascimento de uma literatura para a infância, é o século XIX que Arroyo define como “o século de afirmação" do gênero, citando diversos autores consagrados, como os Irmãos Grimm, Hans Christian Andersen, Lewis Carroll, Júlio Verne, Emilio Salgari, Fenimore Cooper, Rudyard Kipling, Mark Twain, Edgar Rice Burroughs, Carlo Collodi, entre outros (p. 22), que deixaram uma herança literária profícua que adentraria o século XX com inúmeras traduções e adaptações, formando um legado para as crianças de todo o mundo.

Para Arroyo,

o século XVII foi rico de obras importantes para a literatura infantil, mas a Idade de Ouro foi, sem dúvida, o século XVIII. Pretendeu-se dar o balizamento mais significativo, o mesmo ocorrendo em relação ao século XIX, que se inicia com a publicação da coletânea das estórias dos irmãos Grimm [...]. O século XIX foi, por excelência, o século de afirmação da literatura infantil (ARROYO, 2011, p. 21-22).

\footnotetext{
32 Madame Jeanne-Marie Leprince de Beaumont (1711-1780), considerada "o primeiro autor francês cujo essencial da obra é dirigido unicamente às crianças, e a todas as crianças” TRIGON, J. Histoire de la littérature enfantine. Paris: Hachette, 1950 APUD ARROYO, 2011, p. 20.

33 John Newberry (1713-1767), autor do primeiro livro ilustrado para crianças, Little pretty pocket-book (Um lindo livrinho de bolso, 1744). ARROYO, 2011, p. 20.

${ }^{34}$ Robinson Crusoe, de Daniel Defoe (1661-1731), e As viagens de Gulliver, de Jonathan Swift (1667-1745).
} 
Complementando os estudos de Arroyo, Regina Zilberman relembra na introdução de seu livro, A literatura infantil na escola, que "os primeiros livros para crianças foram produzidos ao final do século XVII e durante o século XVIII". Antes disso, não se escrevia para crianças simplesmente porque "a infância não existia" (ZILBERMAN, 2003, p. 15), justifica a autora, ratificando o que já vimos pontuando anteriormente. E complementa: "hoje, a afirmação pode surpreender; todavia, a concepção de uma faixa etária diferenciada, com interesses próprios e necessitando de uma formação específica, só aconteceu em meio à Idade Moderna” (p. 15).

Também Nelly Novaes Coelho aponta o século XIX como decisivo no que se refere ao estabelecimento de uma produção específica para crianças e adolescentes. Em suas palavras, "conhecido literariamente como o século de ouro do romance e da novela", esse período teria sido marcado pela "convergência de diferentes tendências e correntes literárias" (COELHO, 1991, p. 138), abrindo espaço para o surgimento do romance moderno e para uma literatura voltada ao público jovem e infantil. Para a autora,

a criança é descoberta como um ser que precisava de cuidados específicos para sua formação humanística, cívica espiritual, ética e intelectual. E os novos conceitos de vida, educação e cultura abrem caminho para os novos e ainda tateantes procedimentos na área pedagógica e literária. Pode-se dizer que é nesse momento que a criança entra como um valor a ser levado em consideração no processo social e no contexto humano. [...] Nos rastros dessa descoberta da criança, surge também a preocupação com a literatura que lhe serviria para a leitura [...] (COELHO, 1991, p. 139).

Assim, tanto para Zilberman, como para Arroyo ou Coelho, embora desde o século XVII já tenhamos a publicação de obras voltadas para o público infantil, especialmente na França, com as fábulas de La Fontaine 35 (1668) e os contos de Charles Perrault (1697), além de textos de caráter didático, como o Tratado sobre a educação

35 Jean de La Fontaine (1621-1695). 
das meninas, de Fénelon ${ }^{36}$ (De l'éducation des filles, 1687-1696), por exemplo, é no século XIX que esse gênero, finalmente, se consolidaria.

A criança como personagem, porém, não é unanimidade nas primeiras obras voltadas à infância. É o que podemos verificar, por exemplo, nos contos recolhidos e publicados pelos Irmãos Grimm (1812-1822) ${ }^{37}$, que ficaram mundialmente conhecidos, e são, ainda hoje, alvo de constantes adaptações cinematográficas e estudos acadêmicos. Nesses contos, apesar de haver exceções, como em "Chapeuzinho Vermelho", “0 Pequeno Polegar"38, “João e Maria”, “0 irmão e a irmã”, entre outros, a maior parte dos protagonistas não são crianças. Para exemplificar, basta relacionar alguns de seus personagens mais populares, como Branca de Neve, Cinderela e Rapunzel, por exemplo, todas geralmente lembradas em sua forma jovem ou adulta, e não infantil. Há ainda os contos em que os primeiros parágrafos são destinados a relatar a infância do personagem, como em "A Bela Adormecida", por exemplo, mas apenas para elucidar um acontecimento ou contextualizar uma situação, uma vez que o tempo passa rapidamente para que o personagem cresça e o conflito se estabeleça já em sua forma adulta.

Essa constatação pode estar relacionada diretamente ao fato de que as narrativas de Grimm não foram inicialmente concebidas para a criança, uma vez que os irmãos buscaram suas fontes da oralidade, ou seja, em contos populares que circulavam pela Alemanha e eram assim passados de geração a geração. Apesar disso, no que se refere à recepção, a obra de Grimm, segundo Coelho, revela uma "nova preocupação com a criança". De acordo com a autora, embora retirados da tradição oral, alguns contos foram "suavizados" de modo a considerar "as exigências da mentalidade infantil", que eram, a princípio, colocadas "no mesmo plano da mentalidade adulta" (COELHO, 1991, p. 142).

\footnotetext{
36 François Fénelon (1651-1715).

37 Os contos recolhidos pelos irmãos Jacob (1785-1863) e Wilhelm Grimm (1786-1859) foram publicados entre os anos 1812 e 1822 (COELHO, 1991, p.141).

38 Versões de "Chapeuzinho Vermelho" e "O Pequeno Polegar" já haviam sido publicadas anteriormente nos contos de Charles Perrault (1628-1703), em 1697. Na coletânea de Perrault, incluindo originalmente oito contos, também a maior parte dos protagonistas é formada por um conjunto de personagens jovens ou adultos, com exceção dos dois contos citados.
} 
Já nos contos dinamarqueses de Hans Christian Andersen (1835-1872)39, é possível perceber uma abordagem bastante diferente na representação da infância, uma vez que a criança e o universo infantil são inseridos de forma mais realista e natural, sem deixar de lado, porém, o recurso "mágico" característico dessas narrativas. Para Coelho, “uma das peculiaridades de Andersen é a sábia mistura de 'maravilhoso' e 'realismo' existente em sua matéria literária". De acordo com a autora, "a maioria das narrativas de Andersen apresenta personagens, espaço e problemática retirados da realidade comum, conhecida por todos nós". Apesar disso, "o elemento mágico está em tudo, [...] naturalmente presente" (COELHO, 1991, p. 152). Já para Gianni Rodari40, embora o "mundo das fábulas" 41 tenha servido como matéria prima e inspiração tanto para Grimm como para Andersen, diferentemente dos irmãos alemães, que se interessavam "em construir um monumento vivo da língua alemã", o autor dinamarquês "revivia aquelas fábulas em sua memória" como um modo de "reaproximar-se da sua infância para resgatá-la, sem se preocupar em dar voz a seu povo" (RODARI, 1982, p. 49). Em vez disso, Andersen optou por “dar voz" à criança.

Assim, apesar de personagens adultos figurarem também em grande parte de seus Eventyr og historier (Contos de fadas e outras histórias), em Andersen a infância encontra lugar de destaque até mesmo em enredos em que o personagem criança não é verdadeiramente o centro da narrativa. Um exemplo é o conto "O Soldadinho de Chumbo", que narra as aventuras vividas pelo brinquedo desde sua chegada à casa do menino até seu retorno ao lar. Nesse conto, embora o protagonista tenha a forma "adulta" de um soldado, a história se passa no "mundo encantado dos brinquedos", cenário que nos remete a um universo infantil por natureza, inclusive com a presença de personagens crianças que ocupam um papel secundário - porém, fundamental - na trama: o menino que ganha o soldadinho de presente, os garotos que o encontram na calçada (street boys) e aquele que, no final, o atira no fogo (ANDERSEN, 1997, p. 127$132)^{42}$.

\footnotetext{
39 Os 168 contos de Hans Christian Andersen (1805-1875) foram publicados na coletânea Eventyr og historier, entre 1835 e 1872 (COELHO, 1991, p.148).

40 Gianni Rodari (1920-1980). Jornalista, escritor e poeta italiano.

41 "Fábulas", nesse contexto, teria o mesmo significado de "contos", em português, ou "narrativas imaginárias".

42 Não fica claro na narrativa se a criança que atira o soldadinho na lareira no final do conto ("one of the little boys") é o mesmo menino que o recebe como presente de aniversário ("a litte boy"). 0 fato é que, no cenário encontrado pelo soldadinho após seu retorno ao lar há mais crianças na casa ("he saw the
} 
Outro conto de Andersen em que as crianças fazem "uma breve figuração" é “O patinho feio" (ANDERSEN, 1997, p. 127-132), uma das narrativas mais conhecidas do autor. Nesse conto, embora o enredo se desenvolva no mundo animal e os personagens com os quais o patinho convive sejam sempre outros animais (com a exceção de uma "velha senhora"), é pela voz de uma criança que o protagonista toma consciência de sua "nova" condição: era um cisne - "e o mais belo de todos!" (p. 249$250)^{43}$. Além disso, o conto evoca a infância em toda a sua extensão, uma vez que o narrador acompanha o protagonista desde antes de seu nascimento até a maturidade, relatando as agruras e dificuldades pelas quais passa o personagem, como a rejeição da família e dos amigos, o preconceito, a superação de desafios e o autoconhecimento.

Porém talvez a atuação mais relevante que Andersen tenha reservado à criança como "figurante" na narrativa tenha sido em "A roupa nova do imperador" (ANDERSEN, 1997, p. 89-95). Nesse conto, apesar de o enredo todo se passar na esfera do "mundo adulto", no qual o monarca contracena apenas com seus ministros, cortesãos e com os falsos tecelões, o autor guarda para o final um inusitado e indispensável papel para a criança, ao lhe dar a voz que denunciaria a farsa vivida pelo imperador. Desse modo, por meio de olhos inocentes e sem malícia, os adultos conseguem se desprender da ilusão que eles mesmos forjaram com receio de serem julgados e, podem, enfim, apropriar-se da realidade. Esse desfecho denota uma irônica inversão de valores: enquanto os adultos, inseguros quanto a suas próprias qualidades e ludibriados pela vaidade do imperador não podiam sequer duvidar de que estavam sendo enganados, a criança, despida de qualquer necessidade de adulação ou de autoafirmação, revela a fraude sem meias palavras, e declara a realidade dos fatos: "o rei estava mesmo nu" 44 . Uma curiosidade acerca dessa obra é o fato de a versão preliminar do conto não conter a participação infantil no enredo, que viria a ser incluída mais tarde, "provavelmente depois de Andersen ter lido a versão inicial para uma criança"45, revelação que

same children..."). ANDERSEN, H. C. "The hardy tin soldier" IN: The complete fairy tales. Ware (GB), Wordsworth Editions, 1997, pp. 127-132.

43 "Into the garden came little children, who threw bread and corn into the water; and the youngest cried, 'There is a new one!' and the other children shouted joyously: 'Yes, a new one has arrived!' (...) and bread and cake were thrown into the water; and they all said: 'The new one is the most beautiful of all - so young and handsome!' and the old swans bowed their heads before him". ANDERSEN, H.C. "The Ugly Duckling" IN: The complete fairy tales. Ware (GB), Wordsworth Editions, 1997, p. 239-250.

44 "'But he has nothing on', a little child creid out at last (ANDERSEN, H. C. "The Emperor's new clothes" IN: The complete fairy tales. Ware (GB), Wordsworth Editions, 1997, p. 89-95).

${ }^{45}$ De acordo com a biografia de Andersen, por Elias Bredsdorff, a primeira versão do conto terminava com todos admirando os trajes invisíveis do imperador. ("In Andersen's original manuscript the story ends 
reafirmaria o determinante papel da infância em sua obra, tanto na figuração como na recepção.

No que se refere ao protagonismo infantil, no entanto, especialmente por apresentar como personagem central uma criança desvalida e desprotegida, talvez o conto mais lembrado de Andersen seja "A pequena vendedora de fósforos", que propõe como tema central o trabalho infantil, a desigualdade social e a miséria, e expõe, por meio da figura de uma menina, a fragilidade infantil em um mundo injusto e imperfeito. No final do conto, o narrador faz questão de declarar que, apesar da comoção causada pela morte precoce da menina, ela sorria e os transeuntes "não imaginavam as coisas lindas que ela havia visto antes de partir" (ANDERSEN, 1997, p. 345) ${ }^{46}$, chamando a atenção do leitor para o poder da imaginação e da fantasia, capaz de renovar as esperanças e de criar uma contraposição entre a beleza do sonho e a aspereza da realidade.

Desse modo, falando sobre e para a criança, Andersen não só apresenta a infância aos pequenos, como abre caminhos que seriam seguidos de perto por outros autores em todo o mundo ${ }^{47}$.

Gianni Rodari, em ensaio sobre as fábulas populares como substrato para os contos infantis, comparando a obra do autor dinamarquês à do italiano Carlo Collodi ${ }^{48}$ - a quem exalta como "poetas geniais" -, afirma que, embora Andersen possa ser considerado "o criador da fábula contemporânea: aquela em que temas e figuras do

with everybody admiring the emperor's new clothes, the implied moral being that people willingly allow themselves to be deceived".) Porém, alguns dias depois de enviar os originais para a publicação, Andersen teria alterado o final e enviado ao editor responsável pela revisão do texto um novo desfecho, solicitando a substituição do parágrafo final por aquele que ficou mundialmente conhecido. Para Bredsdorff, isso teria ocorrido depois de Andersen ler o conto para uma criança, o que teria feito com que ele mudasse de ideia ("It was this ending - probably added after Andersen had read ther original version to a child which gave Andersen's masterpiece its final touch"). BREDSDORFF, E. Hans Christian Andersen, a biography. Suffolk, Souvenir Press, 1975, p. 312-313.

46 "No one imagined what a beautiful thing she had seen, and in what glory she had gone in with her grandmother to the New Year's joy". ANDERSEN, H.C. "The little match girl" IN: The complete fairy tales. Ware (GB), Wordsworth Editions, 1997, p. 342-345.

47 Nelly Novaes Coelho define essa categoria de contos como "narrativas do realismo-maravilhoso (ou mágico)", que apresentam elementos do cotidiano ao mesmo tempo que "algo de mágico ou de maravilhoso (ou de absurdo)" ocorre e "passam a acontecer coisas que alteram por completo as leis ou regras vigentes no mundo normal". Exemplos: Lewis Carroll (1832-1898); James Matthew Barrie (18601937); Carlo Collodi, pseudônimo do escritor Carlo Lorenzini (1826-1890) (COELHO, 1991, p. 158).

48 Carlo Collodi, pseudônimo do escritor Carlo Lorenzini (1826-1890). Pinóquio tornou-se um grande "clássico" da literatura infantil mundial, tendo sido amplamente divulgado, traduzido, adaptado, contando, já no século XX, com inúmeras versões inclusive para o cinema e a televisão (Le avventure di Pinocchio. Storia di un burattino. Napoli, Fratelli Rispoli, 1883). 
passado abandonam seu limbo para agir no purgatório, ou no inferno, do presente", o criador de Pinóquio teria "ousado mais" quando atribuiu à criança - "a criança como ela é, não como seu professor gostaria que fosse - um papel de protagonista [...]" (RODARI, 1982, p. 50).

Ratificando o que Rodari atesta sobre a obra de Collodi, nos valeremos dos estudos de Andrea Barabino ${ }^{49}$, que pesquisou as origens das representações da infância na literatura desde os textos clássicos gregos e latinos. Em seu ensaio, ele afirma que, até os romances de Dickens, a criança não aparecia como protagonista. 0 autor destaca o final do século XIX como um marco na literatura italiana, citando como representantes desse período duas obras que viriam a ganhar o mundo no século seguinte em inúmeras traduções e adaptações: As aventuras de Pinóquio (Le avventure di Pinocchio. Storia di un burattino, 1883), de Collodi, e o livro escolar Coração (Cuore, 1886), de Edmondo De Amicis $^{50}$ (BARABINO, s/d, p. 4).

Nas palavras do autor,

la letteratura italiana, invece, presenta pochi casi in cui lo scrittore manifesta una sincera, genuina e, soprattutto, costante attenzione per l'infanzia. Alla fine dell'Ottocento probabilmente i due casi di maggior rilievo sono Cuore di De Amicis e Pinocchio di Collodi (BARABINO, s/d, p. 4$)^{51}$.

No que se refere à representação da infância, embora o personagem central da obra de Collodi não seja uma "criança propriamente dita", Barabino atribui à trajetória do boneco de madeira uma importância ainda maior do que à do protagonista de Coração, uma vez que, para alcançar o status de "menino de verdade", Pinóquio fora

${ }^{49}$ Andrea Barabino é professor de literatura grega e latina na Universidade de Gênova. Seu ensaio “L'età dell'innocenza" ("A idade da inocência") está publicado no portal Media Classica - Dipartimento di Antichità, Filosofia e Storia (DAFIST) dell'Università di Genova.

${ }^{50}$ De Amicis, Edmondo (1846-1908). Considerada uma obra primordial na literatura infantil italiana, Cuore (Coração, 1886) foi traduzida para várias línguas e usado como leitura escolar - inclusive no Brasil. O livro apresenta a estrutura narrativa do diário para registrar o cotidiano de Enrico, um estudante do terceiro ano elementar.

51 "A literatura italiana, no entanto, apresenta poucos casos em que o escritor manifesta uma sincera, genuína e sobretudo constante atenção para a infância. Ao final do século XIX, provavelmente os dois casos de maior relevo são os livros Coração de Edmondo De Amicis e Pinóquio, de Carlo Collodi" (tradução nossa). 
submetido a "duras lições", podendo ser comparado ao menino que conquista, por seus próprios méritos, a idade adulta. Para o autor, "ainda que feita de madeira”, a marionete "encarna a idade da infância" (BARABINO, s/d, p. 4).

É importante ressaltar que, diferentemente dos contos de Grimm ou das narrativas de Daniel Defoe e Jonathan Swift ${ }^{52}$, por exemplo, tanto Coração como Pinóquio são obras que já visavam à recepção infantil. Assim, ao contrário dos contos que nasceram da tradição oral - sendo posteriormente adaptados para o público infantil -, em ambas as obras italianas citadas é possível perceber explicitamente a intenção do autor em escrever para crianças. Em Coração, o livro-diário narrado em primeira pessoa pelo menino Enrico, a intencionalidade da obra aparece na forma de uma dedicatória do autor, que precede a narrativa:

Questo libro è particolarmente dedicato ai ragazzi delle scuole elementar, i quali sono tra i nove e i tredici anni, e se potrebbe intitolare: Storia d'un anno scolastico, scritta da un alunno di 3a. d'una scuola municipale d'Italia [...] Ora leggete questo libro, ragazzi: io spero che ne sarete contenti e che vi farà del bene (DE AMICIS, 2005, p. 25). ${ }^{53}$

Já no caso de Pinóquio, embora, ao traduzir Perrault, Collodi tenha bebido da mesma fonte de Grimm e Andersen, ou seja, dos contos nascidos da oralidade, o autor italiano cria uma nova forma de narrar, lançando mão de recursos do conto popular ou conto de fadas como o "Era uma vez", para depois desconstruir a expectativa do leitor de que seu texto vai se comportar como tal. Desse modo, torna-se inusitada a maneira como a narrativa se inicia, por meio de uma breve interlocução entre o narrador e

\footnotetext{
${ }^{52}$ Como já citado anteriormente, tanto Robinson Crusoe (Daniel Defoe, 1719) como As aventuras de Gulliver (Jonathan Swift, 1726) não foram escritas inicialmente para crianças, mas "adotadas" por elas mais tarde.

${ }^{53}$ Cuore, introdução: "Este livro é particularmente dedicado aos meninos das escolas elementares, que têm entre nove e treze anos, e poderia intitular-se História de um ano escolar, escrita por um aluno de terceiro ano de uma escola municipal da Itália [...] Leiam este livro, meninos: eu espero que vocês fiquem contentes e que o livro lhes faça bem" (tradução nossa).
} 
"supostos leitores" - ou ouvintes -, que interrompem o discurso narrativo logo depois do "Era uma vez...":

C'era una volta...

- Un re! - diranno subito i miei piccoli lettori.

- No, ragazzi, avete sbagliato. C'era una volta un pezzo di legno. (COLLODI, 2005, p. 3). ${ }^{54}$

Desse modo, ao mesmo tempo que informa o leitor de que a história não será sobre um rei e não se desenvolverá no mundo encantado dos castelos e fadas, o narrador faz questão de deixar claro que se trata de um conto infantil, usando para isso tanto a expressão "piccoli lettori" como "ragazzi" (meninos). Ratificando a intenção do texto quanto à recepção está o fato de que Storia di un burattino fora primeiramente publicada em capítulos em um pioneiro periódico infantil chamado Giornale per $i$ bambini $(1881)^{55}$. Como o próprio nome sugere, o Jornal para os meninos era dirigido às crianças.

Ou seja, no caso da literatura italiana, as primeiras narrativas que trazem representações da infância em seu enredo são obras já planejadas para a leitura da criança, seja de modo declarado no texto - como na dedicatória de Coração -, seja no artifício do narrador e no meio de publicação - como em Pinóquio, apontando uma coincidência temporal - o século XIX - para o aparecimento das obras sobre e para a criança.

Representações da infância na narrativa literária, contudo, não se limitam apenas a textos classificados como infantis ou infantojuvenis. Hoje, a criança como personagem de ficção pode ser encontrada facilmente tanto em obras destinadas ao público infantil como naquelas que têm como alvo o público adulto, seja na literatura ou

\footnotetext{
54 “Era uma vez... 'Um rei!' - diriam logo meus pequenos leitores. 'Não, meninos, vocês se enganaram. Era uma vez um pedaço de madeira'” (tradução nossa).

55 Devido ao sucesso da narrativa, dois anos mais tarde, em 1883, as aventuras completas do boneco de madeira foram publicadas em um volume único, em forma de livro, com o título Le avventure di Pinocchio (As aventuras de Pinóquio, 1883). 0 suplemento Giornale per i bambini (1881-1889), idealizado por Ferdinando Martini, era um encarte da Fanfulla della domenica, um conhecido jornal romano no qual escreviam os melhores autores da Itália. Em junho de 1889 foi incorporado pelo Giornale dei fanciulli, de Milão.
} 
em outros suportes, como o cinema e a televisão. Porém, assim como a literatura para crianças encontrou seu espaço na Europa principalmente a partir do século XVIII, é também nesse período que começamos a encontrar com maior frequência as representações da infância na narrativa literária.

Segundo Marie-José Chombart de Lauwe ${ }^{56}$, pesquisadora da figuração infantil na ficção francesa dos séculos XIX e XX, "a infância interessou muito pouco à literatura até o final do século XVIII", sendo encontrada apenas "excepcionalmente" (CHOMBART DE LAUWE, 1991, p. 7). A autora atribui essa ausência da criança como personagem e o posterior empenho nessa representação como reflexos da sociedade vigente, afirmando que, ao longo do século XVIII, “as concepções se transformam” e a criança assume, então, "um lugar cada vez mais importante na sociedade", tornando-se, cinquenta anos mais tarde, "objeto de relatos na literatura romanesca". Desse modo, ela justifica a escolha do período em que se situam as obras de sua pesquisa exatamente por ter encontrado, entre os séculos XIX e XX, terreno fértil para investigar essa "mudança das concepções da infância, acompanhada por modificações da situação da criança na sociedade francesa”, aliada à busca por “novas imagens” (CHOMBART DE LAUWE, 1991, p. 7).

De acordo com seus dados,

ao longo do século XVIII, as concepções se transformam, nos Enciclopedistas e em Rousseau. [...] A criança assume então um lugar cada vez mais importante na sociedade, e cinquenta anos mais tarde torna-se objeto de relatos na literatura romanesca. [...] Por volta de 1850, a personagem da criança entra maciçamente na literatura. Os homens descobrem que não existe apenas uma maneira de ser humano, o adulto perde seu prestígio de modelo único. [...] Da mesma forma, após ter decomposto a existência em classes de idades, e tentado definir cada uma delas, assiste-se cada vez mais a um fechamento da infância em um mundo separado, que acabará por ser percebido como uma "raça à parte". A criança-vida torna-se essência da vida (CHOMBART DE LAUWE, 1991, p. 8-9).

${ }^{56}$ Marie-José Chombart de Lauwe (1923). Socióloga francesa. 
Assim, por meio de sua pesquisa literária, a autora reafirma os estudos historiográficos e sociológicos realizados, uma vez que o relevo dado à criança na sociedade passa a se manifestar, consequentemente, na arte da representação.

Violante Magalhães ${ }^{57}$, pesquisadora das representações da infância na literatura portuguesa do século XX, ratifica os achados da pesquisa de Chombart de Lauwe - e vai além -, afirmando que tanto a literatura sobre a criança como a literatura para a criança despontaram no final do século XIX. Em sua tese de doutorado ${ }^{58}$, embora determine como objeto de seus estudos o neorrealismo português, a autora refaz em percurso comparativo os caminhos da representação literária da infância tanto em Portugal como em outros países, inclusive no Brasil, procurando mostrar como a literatura passou a ter um olhar mais diferenciado para a criança na mesma medida em que a criança passava a ter, cada vez mais, a atenção da sociedade.

De acordo com Magalhães, durante séculos, “a infância foi ignorada no mundo dos adultos", tendo sido, "omitida nas obras literárias dos mais diversos países ocidentais" (MAGALHÃES, 2008, p. 103). Para a autora, esse contexto mudou a partir do século XVIII, e especialmente no século XIX, quando a criança passou a figurar na literatura ao mesmo tempo que começou a ser engendrada uma literatura voltada ao público infantil.

Desse modo,

\begin{abstract}
progressivamente, e em particular desde o século XVIII, com o crescente interesse que quase todas as áreas do conhecimento manifestaram por este estrato etário, a infância passou a estar submetida a uma atenção vigilante. Também a literatura na qual perpassa a imagem da criança começou a medrar, especialmente a partir de meados do século XIX; nesse período, despontou ainda a literatura propositadamente dirigida à infância. A evolução foi de tal monta que há actualmente nestes domínios uma produção vasta e de significativa qualidade (MAGALHÃES, 2008, p. 11).
\end{abstract}

57 Violante F. Magalhães, doutora em Literatura Portuguesa e membro do Centro de Estudos Comparatistas da Faculdade de Letras da Universidade de Lisboa, autora dos livros Sobressalto e Espanto. Narrativas Literárias sobre e para a Infância, no Neo-Realismo Português (2009) e A Literatura para Crianças e Jovens em Irene Lisboa (1994).

58 MAGALHÃES, Violante. Sobressalto e espanto: narrativas literárias sobre e para a infância, no neorealismo português. Universidade de Lisboa, 2008 [TESE]. 
Citando Philippe Lejeune, Magalhães revalida os dados encontrados em sua pesquisa, afirmando que, da mesma forma que a infância deixou de ser "ignorada" na sociedade oitocentista, ganhando status de "objeto de maior atenção", também passou a ser alvo de "uma representação diferente, sobretudo em meios socioculturais mais esclarecidos". Para ela, "alguns escritores, independentemente de escreverem ou não para o público infantil, incorporaram-na nos seus textos" (MAGALHÃES, 2008, p. 103).

Para Andrea Barabino, excluindo-se as narrativas para crianças e jovens, a literatura custou a se interessar pela infância, mostrando-se "alérgica" ao tema (BARABINO, s/d, p. 4). Cita como exemplos de obras que trazem o protagonismo infantil os romances ingleses de Charles Dickens (1812-1870) - Oliver Twist e David Copperfield ${ }^{59}$ - e as novelas norte-americanas de Mark Twain (1835-1910) - As aventuras de Tom Sawyer e As aventuras de Huckleberry Finn ${ }^{60}$, todas datadas do século XIX, além do romance juvenil Os meninos da rua Paulo, do escritor húngaro Ferenc Molnár (1878-1952), publicado já no século XX61.

Nas palavras do autor,

anche il romanzo moderno, però, se si esclude la narrativa specifica per $i$ ragazzi, si demostra fondamentalmente "allergico" al mondo dell'infanzia, quanto meno in Italia. In Europa, in effetti, emerge forse un maggiore interesse verso i bambini o i ragazzi, che diventano ora protagonisti, ora addirittura eroi di una moderna micro-epopea nelle opere di Dickens o di Twain: da David Copperfield a Oliver Twist, da Tom Sawyer a Huckleberry Finn, fino al romanzo corale di Molnar, I ragazzi della via Paal (BARABINO, s/d, p. 4)62.

\footnotetext{
59 Oliver Twist (1838); David Copperfield (1850).

${ }^{60}$ As aventuras de Tom Sawyer (1876); As aventuras de Huckleberry Finn (1884).

61 Embora publicado já no século XX (1906), o enredo se passa no final do século XIX, mais precisamente no ano 1889. (MOLNAR, F. Os meninos da rua Paulo).

62 "Porém excluindo-se a literatura para crianças e jovens, também o romance moderno mostrou-se essencialmente 'alérgico' ao mundo infantil, pelo menos na Itália. Na Europa, talvez tenha surgido um interesse maior pelas crianças ou adolescentes, que aparecem ora como protagonistas, ora como heróis de modernas 'microepopeias' nas obras de Dickens e de Twain: de David Copperfield a Oliver Twist, de Tom Sawyer a Huckleberry Finn, até o romance de Molnar, Os meninos da rua Paulo" (tradução nossa).
} 
Desse mesmo período poderiam ser lembradas ainda as obras da Condessa de Ségur63 (Les Petites Filles modèles, 1857, Les Malheurs de Sophie, 1858 e Les vacances, 1859) ${ }^{64}$ e de Charlotte Brontë65 (Jane Eyre, 1847), apenas para citar mais alguns exemplos. Porém dentre os escritores mencionados por Barabino, é importante frisar a relevância de Charles Dickens ${ }^{66}$ no pioneirismo com que abordou a infância em obras não necessariamente infantis.

Violante Magalhães atribui à obra de Dickens "relevo especial" no que se refere à representação da infância. Citando a tese da compatriota Maria Margarida Morgado67, a pesquisadora portuguesa afirma que "a personagem criança irrompeu na obra do autor com uma centralidade e importância até aí nunca vistas" e "mesmo quando não assumia papel protagonista, ela era ali presença temática fulcral" (MAGALHÃES, 2008, p. 104). Ainda com base na tese de Morgado, Magalhães complementa sua tese afirmando que "Dickens denunciou a exploração laboral exercida sobre as crianças e caracterizou-as na sua inocência, pureza e naturalidade".

Para a autora,

o retrato da condição social e psicológica da infância evidencia-se, por exemplo, em Oliver Twist (1838), protagonizado por uma criança órfã, pobre, desprotegida, que personifica o bem, ou em David Copperfield (1850), romance no qual a imaginação e espontaneidade de uma criança lhe conferem capacidade para resistir ao meio hostil da civilização industrial e utilitarista inglesa da época (MAGALHÃES, 2008, p. 104).

${ }^{63}$ Condessa de Ségur (Sophie Feodorovna Rostopchine, 1799-1874).

${ }^{64}$ As meninas exemplares, Os desastres de Sofia e As férias, respectivamente.

${ }^{65}$ Charlotte Brontë (1816-1855).

${ }^{66}$ Charles Dickens (1812-1870).

${ }^{67}$ MORGADO, Maria Margarida. À margem do adulto: quatro estudos sobre a construção cultural da criança. Tese [doutorado]. Lisboa, 1999 apud MAGALHÃES, 2008, p. 104. 
De fato, a obra de Dickens constituiu-se como referência na representação da infância em obras não infantis, dentre as quais alguns protagonistas marcaram época e ainda hoje são conhecidos e estudados. Para Nelly Novaes Coelho, o autor inglês não poupa "denúncias contra os vícios ou abusos sociais", referindo-se "aos pobres, aos humildes e principalmente às crianças exploradas" (COELHO, 1991, p. 186).

Para Fabiana Tavares ${ }^{68}$, em seu estudo sobre as representações da criança da classe trabalhadora na literatura infantil e juvenil, a obra de Dickens "desfila uma série de crianças que traduzem muitos dos arquétipos sociais existentes na sociedade londrina da era vitoriana, muitas das quais eram vítimas do descaso, da negligência e da crueldade das diferentes esferas sociais" (TAVARES, 2014, p. 60). Em sua tese, a autora afirma que, apesar de compor obras ficcionais, isto é, sem qualquer compromisso em retratar a realidade ou o contexto social exatamente como ele é, "Dickens, de fato, fez da sociedade em que vivia ferramenta de criação literária e, no espaço ficcional, teceu críticas de ordem genérica sobre as instituições e os contextos vividos ou testemunhados" (p. 59-60). Desse modo, o autor foi capaz de retratar diferentes tipos de crianças e de classes sociais, desde meninos de rua até aqueles provenientes de classes mais ricas e abastadas.

Estudando o romance Grandes esperanças (Great expectations, 1861), e traçando um perfil do personagem infantil na obra de Dickens, Ricardo Maria dos Santos $^{69}$, citando Kathleen Tillotson ${ }^{70}$, realça a ousadia do autor britânico, afirmando que, na literatura inglesa, nesse período, apresentar "uma criança no papel de protagonista de um romance para adultos era algo virtualmente desconhecido". Para Santos,

o elenco de personagens infantis de Dickens é longo e variado. As crianças protagonistas de seus romances apresentam características diferenciadas pela concepção da obra, pelo estágio de produção estética do autor, pelos objetivos em relação a mensagem, analogias e paródias por parte do autor, e de toda a caracterização engendrada pelo uso do foco narrativo e da tematização particular de determinado texto.

${ }^{68}$ Fabiana Tavares. Doutora e Pesquisadora da área de Estudos Comparados de Literaturas de Língua Portuguesa (FFLCH-USP).

${ }^{69}$ Ricardo Maria dos Santos. Doutor em Letras; Professor da UNESP, Araraquara.

70 BUTT, John \& TILLOTSON, Kathleen. Dickens at Work. London: Routledge and Kegan Paul, 1957. p. 79 APUD SANTOS, Ricardo Maria. "As transformações do conceito de infância em Grandes esperanças, de Charles Dickens" IN: Mediações - Revista de Ciências Sociais, Londrina, v. 10, n.1, jan.-jun. 2005, p. 9-24 
A isto se aliam concepções de caráter social, político e filosófico que estavam latentes, quando da criação do texto e imbricadas na atmosfera do período vitoriano em que Dickens viveu (SANTOS, 2005, p. 18).

Mais do que a simples representação da infância, porém, a obra de Dickens traz retratos da sua própria experiência como criança e do período em que o autor viveu, cercado de incertezas sociais, políticas e econômicas. Para Eileen Simpson ${ }^{71}$, a biografia do autor inglês poderia ser lida como uma de suas novelas (SIMPSON, 1990, p. 201).

Porém, apesar de Dickens ter aberto as portas do romance moderno para as representações da infância já na primeira metade do século XIX, a criança ainda tardou a ocupar papel de destaque como personagem de ficção na literatura europeia, o que só veio ocorrer de forma mais frequente e contínua quase cem anos depois, já em meados do século XX. É o que dizem os estudos de Eduardo Godoy Gallardo ${ }^{72}$, para quem o protagonismo infantil na literatura espanhola até os anos 1940 é de uma "pobreza abismante"73, e os de Gilbert Bosetti ${ }^{74}$, que se refere à criança como protagonista na literatura italiana apenas nas narrativas novecentistas ${ }^{75}$.

Abordando mais especificamente a literatura portuguesa, Violante Magalhães relata que, embora haja exemplos de uma literatura sobre a criança já no século XIX, é a partir da metade do século XX que ela se faz com mais consistência (MAGALHÃES, 2008, p. 12 ${ }^{76}$. Assim, a fim de evidenciar o exponencial crescimento da literatura que traz a criança como personagem nesse período, a autora cita como exemplo a obra de Matilde

\footnotetext{
${ }^{71}$ Eileen Simpson (1918-2002). Escritora, memorialista e psicoterapeuta americana.

${ }^{72}$ Eduardo Godoy Gallardo. Docente do Instituto de Literatura y Ciencias del Lenguaje, Universidade Católica de Valparaíso - Chile.

73 GODOY GALLARDO, Eduardo, La infancia de la narrativa española de posguerra, 1939-1978 (1979). APUD MAGALHÃES, 2008, p. 105.

${ }^{74}$ Gilbert Bosetti. Professor Emérito de literatura italiana na Universidade Stendhal de Grenoble. França.

${ }^{75}$ BOSETTI, Gilbert, autor de L'enfant-dieu et le poète - Culte et poétiques de l'enfance dans le roman italien du XXème siècle, 1997. APUD MAGALHÃES, 2008, p. 105.

76 "As personagens crianças, cujas idades podem ser circunscritas entre o nascimento e os 12 anos, afloraram nos textos de literatura portuguesa para público adulto essencialmente por finais do século XIX. No entanto, foi nos anos 40 do século XX que elas surgiram de forma mais consistente em obras de escritores provindos de diferentes movimentos literários" (MAGALHÃES, 2008, p. 12).
} 
Rosa Araújo77, As crianças todas as crianças (1979) ${ }^{78}$, em que a pesquisadora conterrânea analisa narrativas sobre a infância publicadas até então. Por meio dos seus achados, é possível perceber como no século XX as referências sobre a infância são seis vezes mais frequentes do que no século anterior. De acordo com Magalhães,

\begin{abstract}
do conjunto de trechos apresentados naquela antologia, uma dezena é anterior ao século XX. Na generalidade, esta dezena de trechos de diferentes modos e géneros literários [...] é protagonizada por jovens, daí se inferindo que Matilde Rosa Araújo tem uma visão alargada da categoria infância, na qual incorpora aquele outro estrato etário. Em relação aos textos publicados no século XX, foram seleccionadas seis dezenas deles, maioritariamente narrativos, sendo que metade é ulterior a 1959 e a outra metade é de inícios do século XX até àquela data. [...]. Com estas opções, subtilmente, a antologiadora como que demonstra a exiguidade da produção literária portuguesa sobre a infância e a adolescência antes do século XX e exibe a pujança de tal presença nesse século (MAGALHÃES, 2008, p. 117).
\end{abstract}

Projeção semelhante poderia ser feita no que se refere à literatura brasileira. Vania Maria Resende79, "observando a produção narrativa brasileira moderna”, interessou-se por fazer o "levantamento e a análise de obras, a partir da constante 'infância', como motivo, e da criança, como personagem" (RESENDE, 1988, p. 21). A autora usou como recorte temporal os anos 1922-1987, e procurou abordar a presença do menino na literatura estudando "manifestações de autores cujas obras não foram escritas ao alcance da assimilação infantil [...], bem como de autores que, embora recebendo o rótulo de infantis, não escrevem intencionalmente para o público de faixa etária menor [...]” (p. 24). Entre os “meninos" estudados, figuram personagens de Guimarães Rosa, Autran Dourado, Fernando Sabino e Jorge Amado, além de Ana Maria Machado, Bartolomeu Campos Queiroz e Ziraldo ${ }^{80}$. De acordo com a autora, a análise

\footnotetext{
77 Matilde Rosa Lopes de Araújo (1921-2010). Escritora e pedagoga portuguesa. O conjunto dos seus livros (prosa e poesia) constitui um dos mais significativos trabalhos da literatura portuguesa sobre e para a infância e a juventude.

78 ARAÚJO, Matilde Rosa Lopes. As crianças todas as crianças. Livros Horizonte, Lisboa, 1976.

79 Vania Maria Resende, pesquisadora e professora, doutora em Letras (USP).

80 De acordo com Vania Maria Resende, a "inclusão de Ziraldo, Ana Maria Machado e Bartolomeu Campos Queirós, que habitualmente compõem o quadro de escritores da literatura infantil e juvenil, tem por
} 
teve por objetivo "esclarecer o sentido que cada artista, particularmente, dá à infância, quando a traz à tona no campo da Literatura" (RESENDE, 1988, p. 23). Para isso, a autora encontrou, no século XX, a partir dos anos 1920, um período bastante propício para sua pesquisa.

Porém, se retrocedermos um pouco no tempo, já temos em meados do século XIX, mais propriamente a partir de 1850, algumas obras que envolvem representações da infância. Um exemplo é o romance Memórias de um sargento de milícias (1852) ${ }^{81}$, de Manuel Antônio de Almeida (1831-1861), que apresenta como protagonista o menino Leonardo e acompanha suas peripécias até que o "filho de uma pisadela e de um beliscão" pudesse tornar-se o sargento do título. Uma segunda obra que revela aspectos diferentes da infância é O Ateneu (1888), de Raul Pompeia (1863-1895), em que a passagem do menino Sérgio pelo internato é narrada, trazendo à tona os complexos relacionamentos escolares vividos pelo estudante naquele contexto.

Uma terceira narrativa situada nessa segunda metade do século XIX, também lembrada pelo protagonismo infantil e tendo o ambiente acadêmico como cenário, é “Conto de escola” (1884), de Machado de Assis (1839-1908), publicado pela primeira vez em Várias Histórias (1896) ${ }^{82}$. No enredo, o protagonista Pilar vive um dilema ético com um colega de classe, que resultará no seu "primeiro conhecimento" sobre corrupção e delação. 0 contexto abordado na narrativa lembra episódios vividos por outros personagens em enredos que se inserem na mesma época e temática, envolvendo conflitos e questões cotidianas vivenciadas no ambiente escolar83.

Ainda no que se refere à obra machadiana, é interessante notar como o autor resgata o período marcado pela infância ou adolescência para estruturar alguns de seus mais conhecidos personagens, mesmo em obras que não trazem crianças como protagonistas. É o que ocorre, por exemplo, nos romances Memórias Póstumas de Brás Cubas (1881) e Dom Casmurro (1899), em que o autor usa o recurso do flashback para reavivar na memória de Brás Cubas e Bentinho, respectivamente, o período em que

base o fato de que os três admitem que não escrevem com discriminação de idade, e, portanto, não têm a intenção de que suas obras sejam direcionadas exclusivamente às crianças" (RESENDE, 1988, p. 24).

${ }^{81}$ ALMEIDA, M. A. Memórias de um sargento de milícias, 1852 [Texto de domínio público].

82 Devido à sua temática e por trazer uma criança como protagonista, embora tenha sido escrito em meio a outros contos de temática variada, Conto de escola foi publicado posteriormente como livro infantojuvenil.

83 Como, por exemplo, os já citados Meninos da Rua Paulo (Ferenc Molnar, 1906), Coração (Edmondo De Amicis, 1886) e O Ateneu (Raul Pompeia, 1888). 
foram crianças, para que eles próprios, ao comporem suas autobiografias, pudessem avaliar como essa distante - porém crucial - fase da vida poderia ter influenciado no modo de ser do adulto que se tornaram.

Em Brás Cubas, no capítulo 11 - intitulado “O menino é o pai do homem”, verso emprestado de um poeta ${ }^{84}$-, após relatar sua primeira infância cercada de mimos e afagos, o narrador afirma que cresceu "naturalmente, como crescem as magnólias e os gatos", e faz da frase-título do capítulo o mote para esclarecer o quanto do menino travesso restou no homem que fora. No trecho em que se apresenta como "meninodiabo", atribui a si próprio uma série de desqualificações, bem diferentes do "anjo" adulado no capítulo anterior 85 , revelando sua crueldade com escravos e "moleques da casa", além de outras "artes" que incluíam esconder chapéus das visitas e uma série de "façanhas" dignas de um "gênio indócil” (ASSIS, 2016, p. 42-44):

Desde os cinco anos merecera eu a alcunha de "menino-diabo"; e verdadeiramente não era outra coisa; fui dos mais malignos do meu tempo, arguto, indiscreto, traquinas e voluntarioso. Por exemplo, um dia quebrei a cabeça de uma escrava, porque me negara uma colher do doce de coco que estava fazendo, e, não contente com o malefício, deitei um punhado de cinza ao tacho, e, não satisfeito da travessura, fui dizer à minha mãe que a escrava é que estragara o doce "por pirraça"; e eu tinha apenas seis anos (ASSIS, 2016, p. 42).

Assim, apesar da pouca idade (seis anos), o protagonista já revelava conhecimentos com relação ao distanciamento entre as classes sociais e ao papel dominador do "sinhozinho" ao subjugar os escravos e os "moleques da casa":

${ }^{84}$ ASSIS, M. Memórias póstumas de Brás Cubas. Capítulo 11. "O menino é pai do homem" ("The Child is father of the Man") é um verso do poema My heart leaps up, de William Wordsworth (1802), publicado em Poems in two volumes, em 1807. Em Brás Cubas, o narrador enuncia antes de começar seu relato sobre a infância: "Um poeta dizia que o menino é pai do homem. Se isto é verdade, vejamos alguns lineamentos do menino" (ASSIS, 2016, p. 42).

85 "Se não conto os mimos, os beijos, as admirações, as bênçãos, é porque, se os contasse, não acabaria mais o capítulo, e é preciso acabá-lo" (ASSIS, 2016, p. 41). 
Prudêncio, um moleque de casa, era o meu cavalo de todos os dias; punha as mãos no chão, recebia um cordel nos queixos, à guisa de freio, eu trepava-lhe ao dorso, com uma varinha na mão, fustigava-o, dava mil voltas a um e outro lado, e ele obedecia, - algumas vezes gemendo -, mas obedecia sem dizer palavra, ou, quando muito, um - "ai, nhonhô!" - ao que eu retorquia: “- Cala a boca, besta!” (ASSIS, 2016, p. 42).

Um pouco de malícia e sexualidade também fizeram parte da vida do menino Brás Cubas, encorajado desde os onze anos pelo tio a iniciar-se na descoberta da "obscenidade ou imundície”. Na descrição do protagonista, seu tio João

era um homem de língua solta, vida galante, conversa picaresca. Desde os onze anos entrou a admitir-me às anedotas reais ou não, eivadas todas de obscenidade ou imundície. Não me respeitava a adolescência, como não respeitava a batina do irmão; com a diferença que este fugia logo que ele enveredava por assunto escabroso. Eu não; deixava-me estar, sem entender nada, a princípio, depois entendendo, e enfim achando-lhe graça. No fim de certo tempo, quem o procurava era eu [...] (ASSIS, 2016, p. 43).

Feitas essas considerações a respeito da sua infância de "menino-diabo", o falecido Brás Cubas retoma suas memórias contando mais alguns de seus "galantes episódios" e saltando "por cima da enfadonha escola", onde aprendera a "ler, contar, dar cacholetas, apanhá-las, e ir fazer diabruras, ora nos morros, ora nas praias, onde quer que fosse propício a ociosos" (ASSIS, 2016, p. 45-50), para chegar então à idade do primeiro beijo, aos dezessete anos, no Capítulo 14, deixando para trás a infância.

Já em Dom Casmurro, embora a trama tenha início quando o personagem título já passava de seus cinquenta anos, há três crianças que circulam continuamente pela narrativa, nas lembranças do narrador: Bentinho menino, Capitu menina, e Ezequiel, o filho do casal. Em suas longas memórias de menino, de espécie bem diferente 
das do "menino-diabo", os dezessete anos - "idade em que a metade do homem e a metade do menino formam um só curioso" - chegariam para Bentinho apenas no Capítulo 97, e suas mais intensas lembranças centralizam-se nos sentimentos do protagonista ao descobrir-se apaixonado pela primeira vez (ASSIS, 2016b, p. 580).

0 romance tem início justamente quando o narrador conta os motivos que o levaram a escrever seu livro de memórias, para tentar "atar as duas pontas da vida, e restaurar na velhice, a adolescência". Essa seria, de fato, sua segunda tentativa de restaurar o passado, uma vez que Casmurro confessa, envergonhado - "um desejo tão particular que me vexa imprimi-lo" -, o que já fizera anos atrás, procurando reproduzir, na sua "casa da velhice", o sobrado em que vivera na infância, tempos em que fora feliz (p. 444). Para o narrador, então, restaurar a infância, fosse por meio da escrita de suas memórias ou pela reconstrução da casa, era uma maneira de tentar resgatar a ideia de Capitu menina, quem sabe livre dos "vícios" adquiridos na idade adulta. Porém, apesar de suas tentativas, o protagonista chega à amarga conclusão de que a Capitu adulta ("a Capitu da praia da Glória") já estava dentro da Capitu menina ("a Capitu de Matacavalos”), “como a fruta dentro da casca” (ASSIS, 2016b, p. 638). Essa constatação de que o espírito do adulto em que nos tornamos já vive dentro do nosso corpo de criança pode nos remeter novamente ao verso do poeta William Wordsworth (1802), citado em Brás Cubas: “o menino é o pai do homem” (ASSIS, 2016, p. 42).

Desse modo, com essas duas obras cujo tema central não é a infância propriamente dita, Machado de Assis consegue trazer de volta esse período da vida por meio da lembrança de seus personagens, criando duas representações distintas de crianças: o endiabrado Brás Cubas, com comportamento semelhante ao que encontraremos em obras já datadas do século XX, e o romântico Bentinho, vivendo seu primeiro amor e as típicas emoções que marcam o fim da infância e a entrada na adolescência.

Porém, apesar desses exemplos de representações infantis em obras oitocentistas, é somente nas primeiras décadas século XX que um olhar diferenciado para a infância se faz realmente notar com mais evidência, tanto nas representações da infância na literatura como na criação de uma literatura infantil originalmente brasileira. 
Para Lajolo e Zilberman, "se a literatura infantil europeia teve seu início às vésperas do século XVIII, quando, em 1697, Charles Perrault publicou os célebres Contos da Mamãe Gansa, a literatura infantil brasileira só veio a surgir muito tempo depois" (LAJOLO \& ZILBERMAN, 1999, p. 23), "quase no século XX", tendo-se consolidado mesmo algumas décadas depois, com a publicação das obras de Monteiro Lobato (19201944) (p. 45). Segundo as autoras, é nesse período que a produção literária para crianças ganha volume e interesse, tanto do público como do mercado editorial.

De fato, no cenário da literatura infantil brasileira contemporânea, são incontáveis os protagonistas mirins que se tornaram conhecidos em diferentes períodos. Se tomássemos apenas o século XX como recorte temporal, definindo como ponto de partida os anos 1920, já teríamos uma infinidade de personagens a analisar, como, por exemplo, Narizinho e Pedrinho ${ }^{86}$, de Monteiro Lobato; Cazuza ${ }^{87}$, de Viriato Correa, os primos Eduardo e Henrique ${ }^{88}$, de Maria José Dupré; as crianças de Taquarapoca ${ }^{89}$, de Francisco Marins; a "turma do Gordo"90, de João Carlos Marinho; a menina Raquel, de Lygia Bojunga91; o questionador Marcelo92, de Ruth Rocha; o Menino Maluquinho - e outros diversos "meninos"93 - de Ziraldo, apenas para citar alguns dos mais conhecidos protagonistas de obras clássicas da literatura infantil do século XX.

O ponto de partida certamente é Monteiro Lobato, considerado um "divisor de águas" (COELHO, 1991, p. 225) no que se refere à criação de uma literatura infantil genuinamente brasileira. Sua produção de obras infantis que durou cerca de 25 anos

86 Narizinho aparece pela primeira vez em 1920, no livro A menina do narizinho arrebitado. Já Pedrinho fica conhecido como primo de Narizinho e companheiro de aventuras no desdobramento Reinações de Narizinho (1931), embora tenha aparecido antes em A caçada da onça (1924), que deu origem mais tarde ao livro As caçadas de Pedrinho, quando o menino é, então, o protagonista.

${ }^{87}$ Cazuza, protagonista da obra homônima (1938), de Viriato Correa.

88 Personagens da obra $A$ ilha perdida (1944).

89 Dudu, Tiãozinho e Tico-tico são os três meninos que protagonizam a série de aventuras que ocorrem no sítio Taquara-Poca, inauguradas em Nas terras do rei café, 1945.

90 Edmundo, Pituca e Bolacha (o "Gordo") fazem parte da turma de meninos da 5a série de $O$ gênio do crime (1969), que se tornou um marco na literatura infantojuvenil, iniciando uma série de doze livros com a chamada "Turma do Gordo".

91 Personagem central de $A$ bolsa amarela (1976).

92 Personagem mais conhecido de Ruth Rocha, publicado primeiramente na obra Marcelo, marmelo, martelo (1976), seguido de outras menos conhecidas como A família do Marcelo, A rua do Marcelo.

93 Iniciada em 1980 com $O$ menino maluquinho, a série de meninos de Ziraldo é composta de vários títulos, como: O menino mais bonito do mundo (1983); O menino marrom (1986), O menino quadradinho (1989). A série continua no século XXI, com Os meninos morenos (2004), O menino da Lua (2006), $O$ menino da Terra (2010), Os meninos de Marte (2012), O menino que veio de Vênus (2013), entre outros. 0 próprio Ziraldo faz questão de esclarecer que seus "meninos" são "qualquer ser humano jovem, sem distinção de sexo". Apesar disso, ele dedicou alguns títulos exclusivamente às meninas, como Menina Nina (2002) e Menina das estrelas (2007). 
(1920-1944) abriu as portas do mercado brasileiro para outros autores e editoras interessadas na publicação de obras voltadas para o público jovem.

Interessante notar que, nesse mesmo intervalo de tempo em que surgiam as obras de Lobato, escritas especialmente para as crianças brasileiras, crianças brasileiras eram retratadas como personagens literários de forma bastante realista e diferente daquela imagem edênica e pueril que se tinha em obras ou modelos importados, que traziam uma infância idealizada ao extremo.

Para Marisa Lajolo, em análise sobre a representação da infância na literatura,

já vai longe o tempo em que se podia acreditar numa imagem idílica da infância. Evocada numa perspectiva otimista e saudosa, o início da vida humana costumava traduzir-se em imagens ingênuas, naturais e positivas. A poesia - sobretudo a romântica - teve peso grande na construção desta imagem da infância como vida sem conflitos, que espelha sua beatitude no mar um lago sereno e no céu um manto azulado (LAJOLO, 2011, p. 233, grifos da autora).

Para a autora, essa "representação edênica" da infância perdurou por tanto tempo no imaginário brasileiro que se transformou em "clichê", ou em um "conjunto empoeirado de metáforas", em função, talvez, "da frequência com que compareceu a antologias e manuais escolares" (LAJOLO, 2011, p. 233). Por outro lado, porém, Lajolo lembra que:

várias vertentes da literatura brasileira surpreendem pela presença significativa de crianças ao longo de suas páginas, quase sempre em scripts que invertem radicalmente a representação idílica da infância casimiriana $^{94}$, substituindo a visão ingênua e idealizada por imagens amargas e duras (LAJOLO, 2011, p. 233).

\footnotetext{
94 A autora refere-se ao poema "Meus oito anos" (Casimiro de Abreu, As primaveras, 1859).
} 
Isso se torna visível a partir da década de 1930, quando o movimento modernista alcança a prosa brasileira e há um "grande surto do romance" (CANDIDO \& CASTELLO, 1968, p. 26), com especial destaque para o romance nordestino, que “correspondeu como nenhum outro às aspirações de liberdade temática, atenção ao concreto e vigor estilístico, que então predominavam pelo efeito combinado das transformações políticas e da doutrinação modernista" (p. 27). É nesse período que encontraremos os três romances que fazem parte do nosso estudo e, para situar esse contexto literário em que as obras estão inseridas faremos uma breve recapitulação sobre o Modernismo e os sinais precursores do movimento que quebrou paradigmas e abriu caminhos para uma renovação da literatura brasileira.

\subsection{A literatura brasileira no raiar do século XX: rupturas e ressignificações}

De acordo com Candido \& Castello, a denominação "Modernismo" abrange na literatura brasileira "três fatos intimamente ligados: um movimento, uma estética e um período" (CANDIDO \& CASTELLO, 1968, p. 7). E embora a Semana de Arte Moderna - ou Semana de 22 - seja considerada marco inicial do movimento, é consenso, entre os críticos literários, que já havia, pelo menos desde o início do século, uma "corrente modernista" ou "pré-modernista", definida por Bosi como "tudo o que, nas primeiras décadas do século, problematiza a nossa realidade social e cultural” (BOSI, 1990, p. 343).

Desse modo, mesmo antes de 1920, já era possível perceber tanto na literatura como na arte, de maneira geral, manifestações vanguardistas e algumas movimentações buscando renovação e ruptura com o academicismo vinculado à República Velha, revelando um prenúncio do movimento que se deflagraria alguns anos depois. Assim, no que se refere à prosa, nomes como Euclides da Cunha, Lima Barreto, 
Graça Aranha e Monteiro Lobato são comumente associados a esse período "prémodernista", tendo desempenhado importante papel nesse novo contexto.

Nas palavras de Bosi,

caberia ao romance de Lima Barreto e de Graça Aranha, ao largo ensaísmo social de Euclides, Alberto Torres, Oliveira Viana e Manuel Bonfim, e à vivência brasileira de Monteiro Lobato o papel histórico de mover as águas estagnadas da belle époque, revelando, antes dos modernistas, as tensões que sofria a vida nacional (BOSI, 1990, p. 343344).

Castello também destaca essa fase pré-modernista como fundamental no desenvolvimento do que seria, anos mais tarde, o movimento modernista propriamente dito. 0 autor reconhece um "interregno de transição", que se estenderia de $1902^{95}$ até 1922, quando o movimento modernista se instaurou. 0 ano de 1902 é tomado como referência pelo autor pela publicação de duas obras que "coroam o processo de renovação de mentalidade" proveniente da chamada "Escola do Recife": a História da literatura brasileira, de Silvio Romero, e Os Sertões, de Euclides da Cunha. Acrescenta ainda o romance Canaã, de Graça Aranha, definindo as três obras como textos que “traduzem extraordinário esforço de penetração crítica na realidade brasileira presente, com base na formação do Brasil". Ainda, segundo o autor, essas três obras "nos propõem, com grande repercussão, uma revisão autocrítica, alertando igualmente a criação literária para o compromisso nacionalista ou 'regionalista'” (CASTELLO, 1999, p. 31).

Castello cita, por exemplo, o "idealismo" de Graça Aranha, tanto em seu primeiro romance, Canaã (1902), como em A viagem maravilhosa (1929), já na fase modernista, considerando-as "obras gêmeas" no que se refere à "concepção de vida e no estilo, exaltadamente líricas" (p. 29). Comentando a segunda obra do autor, o crítico afirma que,

\footnotetext{
950 autor cita ainda o ano de 1889 como um possível ano de início da transição, considerando uma delimitação mais política, econômica e social, devido à abolição da escravatura e proclamação da República.
} 
ao dar evasão ao seu idealismo, o romancista equaciona revolução com os problemas individuais e a eliminação de preconceitos. Visa à expansão livre do bem-estar e da felicidade do homem. E o seu lirismo sexual não se limita somente ao comportamento do adulto, também mergulha adentro na adolescência, em investigação que será importante em alguns narradores posteriores (CASTELLO, 1999, p. 31).

Já Alfredo Bosi, tomando o exemplo de Euclides da Cunha, enfatiza que "o moderno em Euclides está na seriedade e boa-fé para com a palavra" (BOSI, 1990, p. 346, grifo do autor). Para Bosi, essa característica aproxima muito mais Os Sertões (1902) dos romances regionalistas dos anos 1930, de Graciliano Ramos e José Lins do Rego, por exemplo, do que dos "romances e contos regionais e neofolclóricos do começo do século, puxados para o pitoresco ou para o piegas", que o precederam (p. 346).

Outros importantes autores dessa fase, lembrados por Castello, são Lima Barreto, cuja "displicência e a independência com relação a estilos literários" fizeram dele "um escritor admirado e reabilitado pelos modernistas que vieram logo após a sua morte"96; Simões Lopes Neto, quem primeiro propôs uma "representação sociocultural de toda uma região através da criação literária" (CASTELLO, 1999, p. 33), cuja autenticidade se revela em uma obra de conteúdo "mítico, lendário e ao mesmo tempo real" (p. 34); Valdomiro Silveira e Hugo de Carvalho Ramos, completando com Simões Lopes Neto a "trilogia que representa uma etapa do regionalismo, voltado para o centro e sul do País" (p. 38, grifo do autor). E, por fim, "os três últimos prosadores" citados por Castello "na posição de persistência e projeção com relação ao advento do Modernismo": Adelino Magalhães, Godofredo Rangel, e Monteiro Lobato, este último a quem o autor considera "um caso à parte, um prenunciador, digno de ser considerado em destaque" (p. 41).

\footnotetext{
${ }^{96} \mathrm{O}$ autor faleceu em 1922, ano da Semana de Arte Moderna (CASTELLO, 1999, p. 32-33).
} 
Embora Lobato não tenha participado como ativista da Semana de 22, atribuise a ele o "relevo" dado a um dos principais fatos desencadeadores da Semana - a exposição de Anita Malfatti, em dezembro de 191797. De acordo com Alfredo Bosi (1990, p. 375), a mostra "serviu de barômetro da opinião pública paulista em face das novas tendências" e a crítica de Lobato, considerada "injusta e virulenta", expôs a face mais tradicionalista do autor, que, ao mesmo tempo que se intitulava favorável ao progresso, às transformações e ao moderno, revelava seu lado mais conservador e "antimodernista". Ainda segundo Bosi, Lobato assumiu "posição ambivalente" no PréModernismo", pois apesar de se mostrar à frente do seu tempo para apontar as "mazelas físicas, sociais e mentais do Brasil", declarava repulsa pelos "ismos", movimentos modernos e "grandes conquistas da arte novecentista" (p. 242).

A despeito das contradições e dos paradoxos que cercam a figura de Monteiro Lobato, é inegável sua importância no cenário literário brasileiro da primeira metade do século XX, não somente pelo pioneirismo com que compôs sua obra infantil, mas também como editor, articulista, tradutor e intelectual atuante na esfera cultural brasileira no início do século passado.

Desse modo, tecidas estas primeiras considerações a respeito do período que precedeu o movimento modernista, como os rumores de uma transformação no cenário artístico e cultural que já se vinham prenunciando desde o início do século, passamos aos anos 1920, período a partir do qual figuram os textos analisados nesta tese.

\footnotetext{
97 Com o texto "Paranoia ou mistificação", Lobato criticou duramente a arte moderna, rotulando-a como "teratológica" e "arte caricatural", e definindo-a como "sugestão estrábica de escolas rebeldes [...] como furúnculos da cultura excessiva", tomando por base a exposição da artista plástica paulista Anita Malfatti. Publicado no jornal O Estado de S. Paulo em 20 de dezembro de 1917, com o título "A Propósito da Exposição Malfatti", o texto reprovou com sarcasmo a importação do que Lobato considerava apenas "modismos" ou correntes europeias, e não propriamente arte.
} 


\subsection{A Semana de 22 e a eclosão do movimento modernista}

Tendo como marco inicial a Semana de Arte Moderna98, em São Paulo, e se prolongando mais tarde por outras regiões do país, em especial, o Nordeste, o Modernismo mostrou como principal característica uma liberdade de criação e expressão, que vinha de encontro ao que era produzido no âmbito das artes até então, "tendo como finalidade principal superar a literatura vigente, formada por restos do Naturalismo, do Parnasianismo e do Simbolismo" (CANDIDO \& CASTELLO, 1968, p. 7). A estética do Modernismo, nem sempre bem delineada ou unificada, trazia novos conceitos de literatura e de escritor, e o período, que se estendeu entre as décadas de 1920 e 1940, apresentou duas fases mais proeminentes: a primeira, considerada mais “dinâmica e agressiva”, até 1930, e a segunda, de "maturação", até o ano de 1945 (p. 7).

Castello propõe ainda a divisão do movimento em três fases, prolongando-o até os anos 1960, definindo as etapas da seguinte forma: uma "fase heroica", por volta dos anos 1920; uma "fase áurea", a partir dos anos 1930, "de equilíbrio construtivo com novas formulações, inclusive a contribuição da chamada 'geração de 45 ' e o engajamento ideológico como atividade militante"; e uma fase final, "pelos anos 1950 e 1960" (CASTELLO, 1999, p. 71).

Em sua fase inicial, o movimento modernista manifestava-se como uma resposta às transformações da sociedade, coincidindo com o centenário da Independência do Brasil, com os ecos da Primeira Guerra, com os resultados da grande imigração que ocorrera anos antes, especialmente nos estados do Sudeste e Sul, e com da fundação do Partido Comunista Brasileiro. Para Candido \& Castello, "a arte e a literatura modernas - antes postas à margem e consideradas caprichos de alguns iconoclastas irresponsáveis" eram então "reconhecidas como expressão legítima da nossa sensibilidade e da nossa mentalidade". De acordo com os autores, "ocorre uma intensa radicalização política, tanto para a esquerda quanto para a direita. E a comoção

\footnotetext{
98 Embora a Semana de Arte Moderna - ou Semana de 22 - seja considerada marco inicial do Modernismo, é consenso entre os críticos literários que já havia, anos antes, uma "corrente modernista" ou "prémodernista", definida por Bosi como "tudo o que, nas primeiras décadas do século, problematiza a nossa realidade social e cultural (BOSI, 1990, p. 343).
} 
das velhas estruturas sociais favorece o desenho de descrever e esquadrinhar a realidade social e espiritual do País" (CANDIDO \& CASTELLO, 1968, p. 7-9).

Outro importante traço do movimento foi a "liberdade criadora" com que os artistas - tanto na literatura como nas artes plásticas - se propuseram a retratar em suas obras a "alma" e os problemas nacionais.

De acordo com Candido \& Castello,

o Modernismo revela, no seu ritmo histórico, uma adesão profunda aos problemas da nossa terra e da nossa história contemporânea. De fato, nenhum outro momento da literatura brasileira é tão vivo sob este aspecto; nenhum reflete com tamanha fidelidade, e ao mesmo tempo com tamanha liberdade criadora, os movimentos da alma nacional (CANDIDO \& CASTELLO, 1968, p. 9).

Não é objetivo desta pesquisa reiterar essas considerações ou apresentar outros vieses no que se refere às discussões sobre o Modernismo, mas apenas contextualizar as obras que serão analisadas neste capítulo dentro das circunstâncias em que foram concebidas, uma vez que o intervalo de tempo entre elas coincide com o período marcado pela maturação do movimento.

Embora não tenha tido inicialmente a mesma repercussão comparada à poesia e às artes plásticas, a prosa também sofreu transformações de extrema relevância após a Semana de Arte Moderna, tanto na ficção como nos manifestos e textos elucidativos do próprio movimento (CANDIDO \& CASTELLO, 1968, p. 25). Esse novo panorama reflete-se em obras como Memórias sentimentais de João Miramar (Oswald de Andrade, 1924); O estrangeiro (Plínio Salgado, 1926); Brás, Bexiga e Barra Funda (Antônio de Alcântara Machado, 1927) e Macunaíma (Mario de Andrade, 1928), entre outras (p. 25-26). 
De acordo com Bosi, "com o advento da prosa revolucionária do grupo de 22 [...], abriu-se caminho para formas mais complexas de ler e de narrar o cotidiano". Ainda, segundo o autor, houve "sobretudo, uma ruptura com certa psicologia convencional que mascarava a relação do ficcionista com o mundo e com seu próprio eu" (1990, p. 436). Para o autor,

o Modernismo, e num plano histórico mais geral, os abalos que sofreu a vida brasileira em torno de 1930 (a crise cafeeira, a Revolução, o acelerado declínio do Nordeste, as fendas nas estruturais locais) condicionaram novos estilos ficcionais marcados pela rudeza, e pela captação direta dos fatos, enfim por uma retomada do naturalismo, bastante funcional no plano da narração-documento que então prevaleceria (BOSI, 1990, p. 436).

Antonio Candido (1967) reitera a importância dos anos 1930 para a prosa modernista, tanto no que se refere a textos não ficcionais, como, por exemplo, o ensaio histórico e sociológico, a crônica polêmica e a análise, quanto para o romance e o conto. Segundo o autor,

a prosa, liberta e amadurecida, se desenvolve no romance e no conto, que vivem uma de suas quadras mais ricas. Romance fortemente marcado de neonaturalismo e de inspiração popular visando aos dramas contidos em aspectos característicos do país: decadência da aristocracia rural e formação do proletariado (José Lins do Rego); poesia e luta do trabalhador (Jorge Amado, Armando Fontes); êxodo rural, cangaço (José Américo de Almeida, Rachel de Queiroz, Graciliano Ramos); vida difícil nas cidades em rápida transformação (Érico Veríssimo) (CANDIDO, 1967, p.145).

Candido \& Castello também citam os anos 1930 como importante marco para os rumos da literatura brasileira, sobretudo na prosa, acreditando que "o decênio de 1930 teve como característica própria um grande surto do romance, tão brilhante quanto o que se verificou entre 1880 e 1910 [...]" (CANDIDO \& CASTELLO, 1968, p. 26). 
De acordo com os autores, apesar de não estarem necessariamente vinculadas à estética modernista, essas obras teriam sido mais bem aceitas devido ao "entusiasmo" inerente às transformações estéticas que aconteciam de maneira geral na poesia e nas outras formas de arte. Desse modo, a partir da década de 1930,

com brusca rapidez, as orientações modernistas vão-se generalizando, impondo-se como legítimas, transformando-se em padrões que enquadram a criação. [...] Há no campo da prosa a entrada na cena literária dos regionalistas nordestinos, e um surto geral de ficção renovada por todo o País. Desses prosadores, alguns representam uma espécie de modernização do Naturalismo; outros enriquecem o romance com preocupações psicológicas e sociais; quase todos aspiram a uma expressão vigorosa e simples, a um estilo liberto do academismo, e por aí coincidem com a atitude dos modernistas. Neste sentido, mesmo quando não provêm da sua doutrinação, beneficiam-se dela, ao aproveitarem a limpeza de horizontes que ela trouxe e impôs (CANDIDO \& CASTELLO, 1968, p. 26).

Assim, embora reconhecendo os importantes precursores desde Franklin Távora, ainda no século XIX, é a partir dos anos 1930 que o regionalismo nordestino entra em uma nova fase, provida de "liberdade temática, atenção ao concreto e vigor estilístico" (CANDIDO \& CASTELLO, 1968, p. 27).

De acordo com Candido,

Távora foi o primeiro "romancista do Nordeste", no sentido em que ainda hoje entendemos a expressão; e deste modo abriu caminho a uma linhagem ilustre, culminada pela geração de 1930 [...]. A virtude maior de Távora foi sentir a importância literária de um levantamento regional; sentir como a ficção é beneficiada pelo contato de uma realidade concretamente demarcada no espaço e no tempo, que serviria de limite e em certos casos, no Romantismo, de corretivo à fantasia (CANDIDO, 1975, p. 300). 
Ainda, segundo o autor, a literatura de Távora - especialmente em obras como O cabeleira (1876) e O matuto (1878) - configura, "sem dúvida, o modesto precursor do agudo senso ecológico de Gilberto Freyre ou, no romance, José Lins do Rego e Graciliano Ramos" (CANDIDO, 1975, p. 301). Na obra de Távora, “a região não era apenas motivo de contemplação, orgulho ou enlevo; mas também complexo de problemas sociais [...]" (p. 303).

Já no século XX, a ficção regionalista nordestina ganhou novos representantes, primeiramente com José Américo de Almeida (A Bagaceira, 1928) e Rachel de Queiroz (O Quinze, 1930). A partir dos anos 1930, entram em cena outros importantes autores, como Jorge Amado, José Lins do Rego e Graciliano Ramos ${ }^{99}$.

Para Candido \& Castello, a ficção regionalista nordestina representou, nos anos 1930-40, "uma das correntes mais poderosas da nossa literatura" (CANDIDO \& CASTELLO, 1968, p. 28), por meio de uma série de obras de cunho regional e social e abordando problemas como a seca e a miséria. Além dos elementos rurais, os autores criaram sua própria identidade e seus traços divergem entre si desde os aspectos da linguagem até os diferentes estilos e ritmos narrativos adotados em cada obra.

Desse modo, segundo os autores, os regionalistas nordestinos:

[...] são bastante diversos uns dos outros, quanto ao estilo e em virtude da multiplicidade de experiência de cada um, conforme suas respectivas áreas de origem, desde o seco e lapidar Graciliano Ramos até o lírico Jorge Amado, passando pela irregularidade pujante de José Lins do Rego, cujo ritmo criador parece esposar a inspiração popular da sua zona (CANDIDO \& CASTELLO, 1968, p. 28).

Não por acaso os três romances que analisaremos ao longo dos próximos capítulos são de autoria desses três grandes representantes da ficção regionalista nordestina, contemporâneos entre si: Menino de engenho (1932), de José Lins do Rego,

\footnotetext{
${ }^{99}$ Jorge Amado com a publicação de O país do carnaval, 1931, e Cacau, 1932; José Lins do Rego com Menino
} de engenho, 1932, e Doidinho, 1933; e Graciliano Ramos com Caetés, 1933. 
por meio do qual acompanhamos a infância do menino Carlinhos; Capitães da areia (1937), de Jorge Amado, no qual analisaremos alguns aspectos da infância dos meninos de rua da Bahia; e, por fim, o livro Infância (1945), de Graciliano Ramos, que nos favorece uma interpretação acerca da reconstrução desse período da vida a partir de fragmentos da memória de seu narrador.

Em nosso estudo, procuraremos mostrar como cada autor cria suas próprias representações de infância e como certos elementos aparecem revelados em suas obras, especialmente no que se refere às heranças de uma sociedade patriarcal e escravocrata. Analisaremos ainda outros aspectos, como o diálogo entre as obras, a inserção da criança na família e suas experiências com a educação formal e informal, com a sua sexualidade e maturação, relacionando cada texto a um importante substrato memorialístico de seus autores, caracterizados ora por sentimentos de perda, ora de reconstrução.

Antes disso, porém, revisitaremos o conto "Negrinha", de Monteiro Lobato, que precede as demais obras, e distancia-se delas tanto na forma (trata-se de um conto, não de um romance) como no período e no contexto político, artístico e social em que foi divulgado, dois anos antes da Semana de 22.

Publicado no mesmo ano em que se inauguraria a literatura infantil de Lobato100, "Negrinha" traz a representação da infância na pele de uma personagem construída por ausências: uma menina sem nome, sem pais, sem lugar, sem esperança, uma contraposição com as crianças do idílico e festivo Sítio do Picapau Amarelo, onde tudo se torna possível por meio da fantasia e da imaginação.

100 LOBATO, M. A menina do narizinho arrebitado. 1920. 
"A criança que mais se diverte com as minhas histórias é a que subsiste ou está renascendo dentro de mim".

Monteiro Lobato (1926) 
Capítulo 2

Lobato, literatura e infância 


\section{Capítulo 2}

\section{Lobato, literatura e infância}

“[...] vou fazer mais livros infantis. As crianças sei que não mudam. São em todos os tempos e em todas as pátrias as mesmas. As mesmas aí, aqui e talvez na China. Que é uma criança? Imaginação e fisiologia; nada mais".

Monteiro Lobato (1930)101

\subsection{0 neto do Visconde}

Infância e literatura são temas intrinsicamente ligados a Monteiro Lobato. Não apenas porque o escritor paulista foi aquele que primeiro se empenhou em engendrar uma literatura infantil genuinamente nacional ${ }^{102}$, mas porque a infância sempre ocupou seu pensamento e suas ideias, mesmo antes que se apresentasse ao Brasil e ao mundo como escritor de sucesso, criador de um conhecido rol de personagens que vão do Jeca Tatu à questionadora boneca Emília. Paralelamente ao ofício de escritor, Lobato mostrava-se um editor auspicioso, um empreendedor pioneiro e determinado, apostando na tecnologia, no ferro e no petróleo como grandes propulsores da modernização do Brasil. Mas é quando se dedica a criar a saga do Sítio do Picapau Amarelo que o autor paulista dá seu tiro mais certeiro.

101 LOBATO, Monteiro. A barca de Gleyre. São Paulo, Globo, 2010, p. 537.

102 Antes de Lobato, Olavo Bilac e Figueiredo Pimentel eram algumas das referências de literatura para crianças. Em 1919 surge o livro Saudade, de Thales de Andrade, mas, de acordo com Lajolo, "toda esta produção pré-lobatiana, quer pelo predomínio do tom didático e moralizante, quer por constituir mera tradução e cópia de modelos europeus, não chega a configurar uma literatura infantil nacional" (LAJOLO, 1983 , p. 46). 
Na área de literatura infantil brasileira, falar de Monteiro Lobato é voltar a dizer o que tantos já disseram antes, uma vez que o universo produzido pelo autor é um dos mais lidos, comentados e estudados. Em uma época em que o que havia para a recepção infantil no país eram algumas traduções e uns poucos contos folclóricos ou exemplares, que mais tinham o ensejo de ditar normas comportamentais do que despertar o interesse da criança para a leitura e para a literatura, o espírito vanguardista de Lobato foi essencial.

Apaixonado pelo progresso e pelas mudanças culturais, políticas e ideológicas que se avolumavam no início do século XX, José Bento Monteiro Lobato (1882-1948)103 deixou-se conhecer por meio de suas obras críticas e literárias, mas também se revelou pelas cartas particulares que vieram a público especialmente a partir dos anos 1940 . Inicialmente relutante à "absurda" ou "sinistra ideia" da publicação de sua correspondência particular, conforme confessa em algumas ocasiões (LOBATO, 2010, p. 378,440 ), o autor cede a pedidos e expõe seu lado mais íntimo para seu público por meio das centenas de cartas que escreveu a amigos e conhecidos ao longo de mais de quarenta anos. Entre elas, as cartas mais conhecidas são aquelas que o autor paulista trocou com Godofredo Rangel (1884-1951), escritor e tradutor mineiro que conviveu com Lobato e com ele se correspondeu até a morte do amigo paulista. E é com ele que o criador do Sítio do Picapau Amarelo compartilha suas impressões sobre a infância, primeiramente observando seus próprios filhos e, mais tarde, sua neta, chegando à conclusão de que a infância brasileira estava maltratada, abandonada à própria sorte, carente de sonhos e de novas perspectivas, tanto na educação como na literatura.

O universo do Sítio de Dona Benta, gestado pouco a pouco e criado ao longo de mais de vinte anos, desde as primeiras ideias até os seus últimos episódios, vem suprir esse vazio, abrindo um caminho a ser seguido por outros autores, instaurando um novo panorama literário para as crianças brasileiras. E a semente desse projeto fora plantada quando Lobato era ainda um menino, o "neto do Visconde", o "Juca Tigre" ou "Juca Zebra", como gostava de assinar suas cartinhas endereçadas à mãe (CAVALHEIRO, 1955, p. 45-46). É para esse período que voltaremos, então, com a ajuda de Edgard

\footnotetext{
103 Seu nome de batismo era José Renato Monteiro Lobato. De acordo com sua biografia (CAVALHEIRO, p. 26), a mudança ocorreu quando o escritor era ainda criança e desejou herdar a bengala de seu pai (José Bento Marcondes Lobato), que tinha as iniciais JBML, alterando por isso seu nome para José Bento.
} 
Cavalheiro ${ }^{104}$, biógrafo de Lobato, que, por meio de sua obra, nos permite conhecer o criador de Emília quando ainda tão jovem.

Em um breve parêntese, é preciso dizer que, dos quatro escritores que serão analisados a partir deste capítulo, Monteiro Lobato foi o único que não escreveu de modo mais explicitamente autobiográfico sobre a própria infância ${ }^{105}$, talvez pela ausência dos dramas necessários a uma boa narrativa. Porém vários elementos de sua meninice aparecem transpostos nas histórias criadas por ele anos depois, entre os cenários e as aventuras dos personagens que habitam o inusitado Sítio do Picapau Amarelo. Para fazer esse paralelo, recorremos à sua biografia.

De acordo com Cavalheiro, o menino Juca, filho de Dona Olímpia e José Bento Lobato, neto do Visconde de Tremembé, teve uma infância feliz, sem intercorrências graves ou outras turbulências. Para o biógrafo, "tudo lhe correra bem":

a infância fora esplêndida, sem nenhuma nuvem a turvá-la. Vida de Fazenda, em casa farta, cercado de carinhos e, principalmente, de compreensão; nenhum choque traumatizar-lhe-ia a sensibilidade infantil. Faziam-lhe as vontades; era senhor de um pequeno reino no qual as vassalas - as irmãs e as crias da casa-grande - em nada o contrariavam [...]. Juca tivera uma infância feliz (CAVALHEIRO, 1955, p. 37).

As memórias mais antigas de Lobato criança constituem um cenário bucólico que, mais tarde, seria rememorado quando o autor decidisse embrenhar-se no campo da literatura infantil. Segundo Cavalheiro,

\footnotetext{
104 Edgard Cavalheiro (1911-1958), escritor, editor e crítico literário, é considerado o mais importante biógrafo de Monteiro Lobato.

105 José Lins do Rego revisitou sua infância em Menino de Engenho e em Meus Verdes Anos, enquanto Jorge Amado e Graciliano Ramos narraram fragmentos da tenra idade em $O$ menino grapiúna e Infância, respectivamente.
} 
a mais antiga lembrança do menino está ligada à natureza e remonta aos cinco anos de idade: da varanda da casa grande, por cima do parapeito, ele descortinava, diariamente, os terreiros de café, cercados pelo muro de taipa que num quadrado fechava o recinto daquele castelo. 0 portão abria-se para a estrada das Sete Voltas, que demandava Taubaté. Depois da estrada o terreno descia íngreme até o ribeirão. Transposto este, começava outro morro. Um morro coberto de escura e misteriosa mata virgem. Da varanda, o pequeno olhava a floresta como um fantástico ninho de onças e de índios (CAVALHEIRO, 1955, p. 18).

Não é difícil associar a descrição desse lugar ao entorno do Sítio de Dona Benta; o ribeirão real, àquele que na ficção abrigaria o Reino das Águas Claras; a mata virgem - em que o próprio escritor aventurou-se a explorar uma vez, acompanhando o pai numa caçada de jacus ${ }^{106}$-, ao cenário de Caçadas de Pedrinho (1933).

A chácara do avô, o Visconde de Tremembé107, que o escritor herdaria e para onde se mudaria com a família anos depois ${ }^{108}$, também serviu a Lobato como inspiração. Na descrição de Cavalheiro,

a chácara do Visconde... Um largo portão dando acesso ao bucólico recanto. Por entre dois renques de mangueiras, avistava-se ao fundo a casa branca, enorme, acolhedora (CAVALHEIRO, 1955, p. 18).

A visão da "casinha branca" do Sítio de Dona Benta é o que se oferece ao leitor na primeira linha escrita por Lobato tanto em A menina do Nariz Arrebitado, de 1920, como em Reinações de Narizinho, de 1932.

\footnotetext{
${ }^{106} 0$ episódio é narrado em CAVALHEIRO, 1955, p. 18-19.

107 José Francisco Monteiro, Barão e depois Visconde de Tremembé, pai de Olímpia Monteiro, mãe do menino Juca.

108 Monteiro Lobato herdou a fazenda do avô em 1911, mudando-se para lá com a família, onde viveria até 1917.
} 
Também o título "Visconde" do avô, associado a suas brincadeiras infantis com sabugos de milho, certamente lhe serviram de argumento para a criação de um de seus personagens mais icônicos e originais: o Visconde de Sabugosa. De acordo com Cavalheiro, "naqueles tempos, nas fazendas, as crianças costumavam brincar com bonecos de sabugo. Tomavam sabugos de milho e os vestiam como se fossem bonecas". Segundo o próprio Lobato, em reflexão já tardia, as crianças

desadoram os brinquedos que dizem tudo, preferindo os toscos onde a imaginação colabore. Entre um polichinelo e um sabugo, acabam conservando o sabugo. É que este ora é um homem, ora uma mulher, ora é carro, ora é boi - e o polichinelo é sempre um raio de polichinelo (CAVALHEIRO, 1955, p. 25).

A cartola do sábio sabugo - que serviu de morada para Emília, em A chave do tamanho (1942) ${ }^{109}$-, provavelmente também fora inspirada por imagens colhidas por Lobato na infância. Em relato de Cavalheiro com trecho transcrito do próprio escritor, o criador do Sítio do Picapau Amarelo revela o deslumbramento que a visão da imponente cartola lhe causou, quando criança:

Dos mestres, o que lhe causou mais viva impressão foi o Dr. Quirino. Muitos anos depois, recorda-o numa página de comovente tributo: "Eu era bem criança quando o vi pela primeira vez: um homem alto, de cartola. A cartola impressionou-me profundamente por ser novidade para mim. E eu corria de onde estivesse, para "ver" a singular estranheza daquele homem alto, desempenado, sempre de preto e de cartola. De cartola! Era a última em uso em Taubaté - em uso diário, porque meu avô possuía uma, mas só para enterros, ou dias de grande gala. O Doutor Quirino usava habitualmente aquela chaminé preta que os ingleses inventaram.

\footnotetext{
109 Nessa história, os personagens do Sítio ficam todos pequenos, devido a uma infelicidade de Emília, que tentava ajudar a acabar com a guerra e acaba mexendo na "chave do tamanho", reduzindo as medidas de todos os seres humanos. Quando volta ao Sítio, a boneca passa a morar na cartola do Visconde.
} 
No mesmo trecho em que descreve a cartola do Dr. Quirino110, Lobato recorda a provável inspiração para escrever, tempos depois, Emília no País da Gramática (1934):

Um dia fui parar em seu Colégio, onde ele era o professor de gramática [...]. 0 que mais tarde me fez escrever Emília no País da Gramática talvez fosse a lembrança do muito que naquele tempo me martirizou a tal "arte de falar e escrever corretamente" (CAVALHEIRO, 1955, p. 25).

Lobato alfabetizou-se cedo, antes dos seis anos, ensinado pela própria mãe. Embora se tenha tornado um escritor de linguagem elaborada, a gramática sempre foi vista por ele com certa ressalva, inclusive em cartas endereçadas ao amigo Godofredo Rangel, para o qual, algumas vezes, solicita ajuda111. A insegurança com relação à gramática vem de quando frequentava o Colégio e fora reprovado em um exame oral de Português. De acordo com Cavalheiro, esse foi o "primeiro choque realmente sério" na vida do menino Juca, quando já tinha treze anos de idade:

É, pois, como um impacto, a princípio incompreensível, que o deixa estatelado, com vontade de morrer, que recebe a terrível, a estonteante notícia de que fora reprovado no exame de Português [...]. Fora um choque brutal para ele [...]. Sente-se arrasado. A vergonha enrubesce-o. Que diriam em Taubaté? Mais tarde se vingará da gramática e dos gramáticos. Agora o que o domina é o desejo de sumir, desaparecer (CAVALHEIRO, 1955, p. 38).

\footnotetext{
${ }^{110}$ Dr. Quirino, professor de gramática, era avô daquela que seria sua futura esposa.

111 "Que bela gramática és, amigo! Recebi o cartão e graças a ele tirei do lombo o peso duma dúvida horrenda. Como o que me pareceu asneira vinha logo no começo do artigo do Estado, corei e tremi ante a hipótese de 50 mil risinhos de mofa gramatical. Quis consultar uma gramática; só encontrei na minha biblioteca uns pedaços da gramática francesa Sevene dos meus tempos de escola [...]. Por fim resolvi consultar-te. Recebi a resposta e respirei. Renasci como se houvesse recebido na testa um beijo de Minerva. Obrigado, generoso amigo". Carta escrita por Lobato em janeiro de 1917 (LOBATO, 2010, p. 387).
} 
Apesar de todo o dissabor causado por esse episódio, o interesse de Juca pelos livros sempre foi grande, e seu apreço pela literatura e pela arte se perpetuaria ao longo de toda a sua vida. Sua lembrança de menino cercado por outras crianças a degustar os livros "que lhe caíam nas mãos" nos remete à figura de Dona Benta, rodeada pelos netos e demais moradores do Sítio, a narrar fábulas e outras histórias.

Segundo Cavalheiro, os divertimentos preferidos do menino Juca

inclinavam-se, cada vez mais, para o garatujar incessante e o incessante debruçar-se sobre os poucos livros que lhe caíam nas mãos. Não havia muitos volumes para crianças naquele tempo. Ele conseguira reunir uns poucos, que lia e relia: três obras de Laemmert, adaptadas por Jansen Müller, e dois álbuns de cenas coloridas - "O Menino Verde" e o "João Felpudo". Havia ainda o "Robinson" resumido e certo livro de narrativas ingênuas intitulado "Dez contos", incansavelmente lidos e relidos [...]. Um quadro de que Monteiro Lobato guardava nítida imagem era o dele entre a criançada humilde, crias da casa em geral, e as irmãs, todos a rodearem-no, enquanto folheava as páginas desses livros, mostrando-lhes as figuras e lendo-lhes os dizeres (CAVALHEIRO, 1955, p. 26).

Essas leituras infantis retornaram à sua memória em 1926, quando Lobato, então já um senhor de quarenta e quatro anos, morando no Rio de Janeiro e autor de sucesso, retomava a ideia de escrever para crianças. Reclamando do calor do Rio e da "primavera eterna" em que tudo é sempre verde, o autor lembra seu álbum de infância e compartilha com o amigo:

Não ficarei muito tempo nesta terra. [...] Verde, verde o ano inteiro! Tudo verde, como o Menino Verde, um álbum colorido com que me diverti em criança, companheiro do João Felpudo: lembra-te disso? Pobres das crianças daquele tempo! Nada tinham para ler. Ando com ideias de entrar por esse caminho: livros para crianças. De escrever para adultos já me enjoei. Bichos sem graça. Mas para as crianças, um livro é todo um mundo. Lembro-me de como vivi dentro do Robinson Crusoe do Laemmert. Ainda acabo fazendo livros onde as nossas crianças possam morar (LOBATO, 2010, p. 513)112.

112 Carta de Lobato a Rangel, maio de 1926. 
Desse modo, Lobato fez da sua própria infância fonte de inspiração não para escrever suas memórias, mas para colocar a literatura infantil brasileira em outro patamar, criando uma obra singular e oferecendo às nossas crianças livros de leitura repletos de imaginação e fantasia, fugindo dos modelos europeus que vigiam até então. Para isso, valeu-se das lembranças de menino, da ausência de uma literatura infantil de qualidade que pudesse interessar às crianças e da vontade que tinha em mudar esse cenário nacional.

Em uma de suas últimas cartas a Rangel, datada de março de 1943, em que Lobato contava ao amigo que, com as tiragens do ano, seus livros infantis passariam de um milhão de cópias vendidas, recorda o Robinson lido aos onze anos de idade e discorre sobre a diferença entre a criança e o adulto:

Ah, Rangel, que mundos diferentes, o do adulto e o da criança! Por não compreender isso e considerar a criança "um adulto em ponto pequeno" é que tantos escritores fracassam na literatura infantil e um Andersen fica eterno (LOBATO, 2010, p. 555).

Antes disso, constatava:

Estou condenado a ser o Andersen desta terra - talvez da América Latina [...]. E isso não deixa de me assustar, porque tenho bem viva a recordação das minhas primeiras leituras. Não me lembro do que li ontem, mas tenho bem vivo o Robinson inteirinho - o meu Robinson dos 11 anos. A receptividade do cérebro infantil ainda limpo de impressões é algo tremendo [...] (LOBATO, 2010, p. 554).

Essa consciência de que a infância deveria ser vista com outros olhos e que fez Monteiro Lobato passar à história da literatura brasileira como um marco - não apenas por inaugurar uma literatura infantil nacional, mas por abrir caminhos por onde, depois dele, outros pudessem seguir - revela-se bem antes, porém, como se pode depreender por meio da leitura de suas cartas mais antigas. 


\subsection{Revelações e impressões de Lobato sobre a infância}

De acordo com Cavalheiro,

há, dizia Lobato, lembranças da meninice que jamais se apagam do cérebro adulto, mesmo quando esse receptor de impressões não consegue, por fraqueza senil, reter as da véspera (CAVALHEIRO, 1955, p. 28).

Por certo as lembranças do menino Juca perseveraram na memória do escritor maduro ao longo de sua carreira, porém outros elementos foram somando-se a essas percepções da meninice, fazendo com que o escritor vislumbrasse na recepção infantil brasileira um alvo em que valeria a pena investir. Muitas das impressões de Lobato sobre a infância podem ser testemunhadas na leitura de suas cartas.

Para Marisa Lajolo, “cartas, campanhas e livros são alguns dos caminhos que podem nos conduzir à pessoa do escritor Monteiro Lobato". Mas logo em seguida ela mesma se pergunta: "Será que conduzem mesmo?" (2000, p. 10). E assim justifica sua dúvida:

[...] nem todas as veredas ao longo das quais Monteiro Lobato viveu sua vida dão conta dela. Pois que caminhos dão conta da vida de uma pessoa? Mas são, pelo menos, rastros de um caminho que, na paixão com que foram impressos, delineiam a figura do nativo de Áries: voluntarioso e volúvel, obcecado, que, como seu signo, baixa a cabeça e vai dando marradas pela vida afora (LAJOLO, 2000, p. 10).

Pois foi na busca desses "rastros de um caminho" que estudamos a correspondência que Lobato nos deixou, especialmente no volume intitulado $A$ barca de Gleyre, coletânea que reúne cartas a Godofredo Rangel, escritas durante mais de quatro 
décadas (de 1903 a 1948113) e tornadas públicas em 1944. Nesse acervo, é possível encontrar o criador do Sítio do Picapau Amarelo mais próximo de suas reais convicções, de seus ideais e de seu pensamento sobre a vida e sobre o mundo; sem as restrições do "politicamente correto" ou a maquiagem da literatura. Para Lobato, "língua de cartas é língua em mangas de camisa e pé no chão - como a falada", ou seja, não requer o rigor gramatical nem a autocensura que outros escritos públicos exigiriam (LOBATO, 2010, p. 76). 0 próprio autor assim explicaria esse "desnudamento" aflorado por meio da publicação de sua correspondência particular, que o fez refletir muito antes de divulgar algo que lhe era essencialmente privado e pessoal:

O gênero "carta" não é literatura, é algo à margem da literatura... Porque literatura é uma atitude - é a nossa atitude diante desse monstro chamado Público, para o qual o respeito humano nos manda mentir com elegância, arte, pronomes no lugar e sem um só verbo que discorde do sujeito. [...] Mas cartas não... Carta é conversa com um amigo, é um duo - e é nos duos que está o mínimo de mentira humana" (LOBATO, 2010, p. 31).

Para o poeta e crítico literário Cassiano Nunes ${ }^{114}$, que se dedicou ao estudo das cartas de Lobato, "a correspondência constitui uma das formas mais legítimas e palpitantes de expressão do humano" (NUNES, 1982, p. 4). Para justificar a inclusão da epistolografia como matéria-prima para pesquisa, o autor relembra "diálogos imortais" que ficaram "gravados perenemente" em cartas, citando como exemplo, entre outras ${ }^{115}$, a correspondência entre Goethe e Schiller ${ }^{116}$ e entre George Sand e Gustave Flaubert ${ }^{117}$,

\footnotetext{
113 Inicialmente, as cartas contemplavam até o ano de 1943; na edição de 2010 foram incluídas cartas até a última, de 1948.

114 Cassiano Nunes (1921-2007). Poeta, escritor e crítico literário.

$115 \mathrm{O}$ autor se refere ainda aos epistolários de Hemingway, Thomas Wolfe, Thomas Mann, Brecht, Virgina Woolf, Joyce, Gorrferied Benn, entre outros escritores, além de cartas de compositores, como Berlioz, Debussy e Schönberg; de pintores, como Van Gogh, Césanne, Kandisnsky, Paul Klee, e ainda de filósofos, políticos e teólogos, entre os quais, Karl Barth, que vêm sendo publicadas.

116 A correspondência inclui 136 cartas trocadas entre os autores alemães Johann Wolfgang von Goethe e Johann Christoph Friedrich von Schiller, de 1794 a 1803.

117 Correspondência trocada entre o romancista Gustave Flaubert e a escritora francesa George Sand, no período de 1863 a 1876, durante 13 anos, até a morte da escritora em 1876, perfazendo um total de 422 cartas.
} 
datando a valorização do gênero a tempos da "mais remota antiguidade" (NUNES, 1982, p. 4-7).

Para Nunes, em ensaio publicado nos anos 1980, o estudo de cartas é "um dos melhores meios de analisar e interpretar a literatura e a História" (NUNES, 1983, p. 5). Em seu texto, o crítico avalia essa espécie de pesquisa no Brasil, mostrando-se descontente com o desinteresse pelo gênero (1983, p. 5-6).

Para o historiador Cauby Dantas118, cartas são, em essência, "documentos íntimos" (DANTAS, 2015, p. 23). Para ele, diferentemente do que ocorre em textos públicos, nas cartas, os interlocutores colocam-se em uma relação "eivada de afeto, circundada de privacidade" e "o despojamento e a informalidade do tom" se dão "em nome da confiança mútua" (p. 23).

A fim de validar seus dizeres, Dantas cita o filósofo e crítico literário italiano, Antonio Gramsci ${ }^{119}$, para quem "há uma diferença de estilo entre os escritos dedicados ao público e os demais, como, por exemplo, entre as cartas e as obras literárias". Para Gramsci, ao estudar textos públicos e privados de um mesmo indivíduo,

parece estarmos a tratar com dois escritores diversos, tão grande é a diferença. Nas cartas [...], nas memórias e geralmente em todos os escritos dedicados a um público pequeno e a si mesmo, predomina a sobriedade, a simplicidade, a imediaticidade, ao passo que nos demais escritos predomina a retórica, o estilo oratório, a hipocrisia estilística (GRAMSCI, 1986 apud DANTAS, 2015, p. 23-24).

0 próprio Monteiro Lobato demonstra compartilhar esse mesmo pensamento, quando repreende Rangel duramente e mostra seu desapontamento com o amigo depois de o escritor mineiro tornar públicos trechos de cartas suas, muito antes que se cogitasse a ideia de se divulgar a correspondência entre os dois. A expressão

\footnotetext{
118 Cauby Dantas estudou, em seu mestrado, o diálogo entre a obra sociológica de Gilberto Freyre e a literatura de José Lins do Rego, valendo-se inclusive da "intensa e prolixa correspondência" trocada entre ambos no período de 1924 a 1957. As cartas utilizadas em sua pesquisa (238, no total: 116 escritas por Gilberto Freyre, 122 por José Lins) fazem parte do acervo do Museu José Lins do Rego, da Fundação Espaço Cultural da Paraíba (FUNESC) (DANTAS, 2015, p. 23).

${ }^{119}$ Antonio Gramsci (1891-1937).
} 
latina "tu quoque"120 usada pelo autor paulista exprime a indignação e o sentimento de "traição" experimentados por ele:

Tu quoque! Até você a publicar trechos de cartas minhas! Não há nada que me desaponte tanto, porque sou um perante o Respeitável Público e outro na intimidade (LOBATO, 2010, p. 529).

Assim, a leitura das cartas em A barca de Gleyre permite-nos extrair de Monteiro Lobato revelações, reflexões e pensamentos que, em suas obras críticas ou literárias, talvez jamais se depreendessem, especialmente porque, nessa correspondência entre o autor paulista e o mineiro, há muito mais do que uma mera interlocução entre dois amigos que permutam confidências sobre cenas cotidianas de seu contexto familiar e privado; há comentários, análises e divagações sobre a história do Brasil, do clima social da época e da literatura brasileira moderna que, passo a passo, estava sendo construída.

Desse modo, a epígrafe que abre este capítulo, retirada de uma carta de Lobato a Rangel escrita em junho de 1930, quando o autor vivia em Nova York ${ }^{121}$, revela seu pensamento mais íntimo sobre a criança, especialmente sobre a criança brasileira, a quem se destinaria a literatura que seria produzida por ele a partir de então.

Portanto, diferentemente do que atestaria Philippe Ariès anos mais tarde ${ }^{122}$ para quem as diferentes concepções de infância são moldadas pela sociedade de acordo com cada época e contexto -, para Lobato, criança era criança em qualquer lugar do mundo, "aqui e talvez na China" (LOBATO, 2010, p. 537). Talvez por isso sua convicção de que a literatura infantil talvez fosse o caminho "mais seguro" a seguir para retomar

\footnotetext{
120 "Tu quoque", expressão latina que demonstra indignação, e remonta à célebre frase dita pelo Imperador Júlio César ao seu filho adotivo, Bruto, enquanto era apunhalado pelas costas: "tu quoque Brutus fili mi?", que significa, literalmente, "Até tu, Bruto, filho meu?".

121 Monteiro Lobato viveu em Nova York de 1927 a 1930.

122 Philippe Ariès publicou o célebre História social da criança e da família em 1960, doze anos, portanto, após a morte de Lobato.
} 
sua carreira de escritor e empreendedor, uma vez que, fora do Brasil, em uma época em que a comunicação era precária, já perdia de vista as tendências literárias do país.

Nesse sentido, cabe uma rápida contextualização sobre as circunstâncias em que essa carta foi escrita.

Distante de sua terra natal e ambientado em uma cultura diferente, Lobato vivenciava um período de grandes mudanças e transformações. Observava em seu cotidiano americano um futuro que, no Brasil, lhe parecia longínquo tanto no tempo como no espaço. Segundo suas próprias palavras, sentia-se "desambientado" e já não sabia "qual o gosto" da "sua" gente. Nestes excertos, extraídos de cartas escritas entre 1927 e 1928, o escritor exprime seu entusiasmo pelo progresso que encontrara na "América" e pela modernidade que experimentava morando na cidade de Nova York:

Sinto-me encantado pela América. 0 país com que sonhava. Eficiência! Galope! Futuro! Ninguém andando de costas! [...] Eu sou um peixe que esteve fora d'água desde 1882, quando nasci, e só agora caio nela. [...] Tudo como quero, como sempre sonhei. [...] Isto é tão imenso, tão desmarcado, tão fora de proporções com o nosso mundinho aí, que é tolice querer dar uma ideia. Teatros, beleza feminina... os arranhacéus... o orçamento da cidade... o perpétuo Amazonas de automóveis... [...] 0 rush deste país rumo ao futuro é um fenômeno [...]! [...] 0 sonho que localizei em séculos futuros encontro realizado aqui (LOBATO, 2010, p. 521-527).

Já em 1930, Lobato revela certo incômodo com sua "vida americana", mostrando-se desiludido por investimentos equivocados na Bolsa, nostalgia pelo tempo que passou e que não voltaria mais, e por um tempo do qual, apesar de tudo, tinha saudades. O trecho abaixo mostra como o autor se sentia longe da Pátria, em comparação com o amigo, que permanecera no Brasil:

Você ficou no mesmo canteirinho onde te plantaram. Permaneceu árvore e por isso dás lindos frutos e em cada estação uma safra. Eu virei nem sei o que - cigano, jumping bean, "tudo quer e nada pega" e acabei expatriado neste mundo tão avesso do nosso mundinho afro-latino. [...] 
Tenho receio de indicar livros [...]. Já me sinto desambientado daí e não sei qual o gosto da nossa gente hoje. Gosto é coisa que muda muito e depressa. [...] 0 nosso Brasil anda tão fora do mundo moderno, tão aparte de tudo [...] (LOBATO, 2010, p. 535-537).

Essa ausência de conexão com o Brasil, aliada à vontade de voltar a escrever ("a famosa comichão vem vindo") e à necessidade de aumentar sua fonte de renda ("quando o bolso se esvazia") serviram-lhe de estímulo para que Lobato se sentisse "ressuscitando literariamente", voltando seus esforços justamente para retomar sua obra infantil, semente lançada dez anos antes, com a publicação de $A$ menina do narizinho arrebitado (1920). Afastado do mercado editorial brasileiro e do consequente "gosto" do povo, o autor acreditava ser um investimento mais garantido apostar na literatura infantil, com a convicção de que "as crianças não mudam" (LOBATO, 2010, p. 535-537). Além disso, acabara de ser avô, e, em convivência com sua neta, Joyce, aprendia a admirar a infância sem os olhos preocupados e inexperientes dos pais. De acordo com ele, os avós, por serem "mais vividos" e provarem um maior distanciamento da mocidade e da "criancice", podem apreciar melhor "o milagre que é a criança" (p. 536).

Um ano depois de registradas essas impressões e considerações sobre a infância, estava publicado o livro que marcaria o renascimento de Lobato na literatura - Reinações de Narizinho -, que ampliava a narrativa original de 1920, mas ainda seria modificado mais uma vez dois anos depois, para atender à demanda de seu criador, com o acréscimo de vários episódios e personagens, dando nova vida ao Sítio do Picapau Amarelo. A coleção de obras que viria em seguida, e que se tornaria "um verdadeiro Rocambole infantil", nas palavras de seu autor, estabeleceria um marco definitivo na história da literatura infantil brasileira.

Assim, em outubro de 1934, Lobato mostrava ao amigo Rangel toda a sua empolgação e o seu entusiasmo pelo seu ambicioso projeto que crescia em sua mente e ganhava novos rumos: 
Tenho em composição um livro absolutamente original, Reinações de Narizinho - consolidação num volume grande dessas aventuras que tenho publicado por partes, com melhorias, aumentos e unificações num todo harmônico. Trezentas páginas em corpo 10 - livro para ler, não para ver, como esses de papel grosso e mais desenhos do que texto. Estou gostando tanto, que brigarei com quem não gostar. Estupendo, Rangel! E os novos livros que tenho na cabeça ainda são mais originais. Vou fazer um verdadeiro Rocambole infantil, coisa que não acabe mais. Aventuras do meu pessoalzinho lá no céu, de astro em astro, por cima da Via Láctea, no anel de Saturno, onde brincam de escorregar... E a pobre da tia Nastácia metida no embrulho, levada sem que ela o perceba... A conversa da preta com Kepler e Newton, encontrados por lá medindo com a trena certas distâncias astronômicas para confundir o Albert Einstein, é algo prodigioso de contraste cômico. Pela primeira vez estou a entusiasmar-me por uma obra (LOBATO, 2010, p. 542).

A ideia de criar uma literatura para a infância, no entanto, surgira quase duas décadas antes, quando Lobato ainda vivia na Fazenda Buquira e observava o interesse com que seus próprios filhos ouviam as histórias que a mãe ${ }^{123}$ lhes contava. Desse modo, em setembro de 1916, enquanto se ocupava com pesquisas sobre lendas brasileiras, entre as quais, a do saci, Lobato confidencia a Rangel a vontade de "vestir à nacional" as fábulas de Esopo e La Fontaine, na tentativa de tornar a literatura algo mais "palatável” para as crianças brasileiras. No trecho abaixo o autor explicita bem o projeto:

Ando com várias ideias. Uma: vestir à nacional as velhas fábulas de Esopo e La Fontaine, tudo em prosa e mexendo nas moralidades. Coisa para crianças. Veio-me diante da atenção curiosa com que meus pequenos ouvem as fábulas que Purezinha lhes conta. Guardam-nas de memória e vão recontá-las aos amigos [...]. Ora, um fabulário nosso, com bichos daqui em vez dos exóticos, se feito com arte e talento dará coisa preciosa. As fábulas em português que conheço, em geral traduções de La Fontaine, são pequenas moitas de amora-do-mato - espinhentas e impenetráveis (LOBATO, 2010, p. 370).

123 Maria Pureza da Natividade, com quem Lobato se casou em 28 de março de 1908 e a quem o autor chama de Purezinha. Seus filhos: Marta (1909), Edgard (1910), Guilherme (1912) e Rute (1916). 
Ao final da carta, Lobato critica a ausência de uma literatura infantil brasileira, que pudesse interessar a seus filhos:

Fábulas assim seriam um começo da literatura que nos falta. Como tenho um certo jeito para impingir gato por lebre, isto é, habilidade por talento, ando com ideia de iniciar a coisa. É de tal pobreza e tão besta a nossa literatura infantil, que nada acho para a iniciação de meus filhos. Mais tarde só poderei dar-lhes o Coração de Amicis - um livro tendente a formar italianinhos... (LOBATO, 2010, p. 370).

Porém, na perspectiva de Lobato, não era somente a literatura que faltava às crianças brasileiras. A descrença do autor acerca da educação e da política aparecem descritas em outras cartas desse mesmo período, como é possível depreender dos trechos abaixo, em correspondências de 1916 e 1917, em que o autor questiona a educação no Brasil:

Ainda não cuidei de ensinar a ler aos meus pequenos, que aliás já conhecem todas as letras. Valerá a pena neste país saber ler? (1916). Dói-me ter filhos, Rangel. Como educá-los nesta terra? Em que princípios? Que moral ensinar-lhes? Nossa ascensão como povo é ladeira abaixo. (1917) (LOBAT0, 2010, p. 370 e 415).

No final de 1917, Lobato começa a planejar uma temporada na Europa, com o intuito de analisar o Brasil de fora, para entendê-lo melhor. De acordo com suas palavras, ele poderia "de lá ver bem e bem estudar este Brasil"; e para isso era necessário colocar-se longe, "para olhar e ver se o Brasil é coisa que mereça consideração" (LOBATO, 2010, p. 417). 0 plano afinal não se concretizou, devido à guerra, mas nessa carta é curioso o modo irônico com que o autor se refere à educação brasileira: "Pretendo ir sem prazo de volta. Deixo os filhos num colégio, estudando o Padre Feijó e outras beterrabas" (p. 417). 
O ano de 1917 ainda seria decisivo para Lobato e no curso que sua vida tomaria a partir daí, com a venda da fazenda e a mudança para São Paulo. Em 1918 seria publicado seu primeiro livro de contos, Urupês, e Lobato inauguraria sua carreira como editor. Mas a ideia da literatura infantil retorna como tema novamente em 1919, em carta datada de abril:

Tive ideia do livrinho que vai para experiência do público infantil escolar, que em matéria fabulística anda a nenhuma. Há umas fábulas de João Kopke, mas em verso - e diz o Correia que os versos do Kopke são versos do Kopke, isto é, insultos e de não fácil compreensão por cérebros ainda tenros. Fiz então o que vai. Tomei de La Fontaine o enredo e vesti-o à minha moda, ao sabor do meu capricho, crente como sou de que o capricho é o melhor dos figurinos. A mim parecem boas e bem ajustadas ao fim - mas a coruja sempre acha lindos os filhotes (LOBATO, 2010, p. 436).

Porém o livro a que Lobato se refere (Fábulas, 1922) seria lançado somente três anos mais tarde. Antes disso, ele investe na história que daria origem a toda a saga do Sítio do Picapau Amarelo: A menina do narizinho arrebitado, em que pela primeira vez, vem a público a personagem título, em uma narrativa ainda bem distante daquela que ficaria conhecida em Reinações de Narizinho, publicada doze anos mais tarde. Em fevereiro de 1921, envia o exemplar a Rangel, solicitando sua aprovação:

Mando-te o Narizinho escolar. Quero tua impressão de professor acostumado a lidar com crianças. Experimente nalgumas, a ver se se interessam. Só procuro isso: que interessem às crianças (LOBATO, 2010, p. 462).

Em abril do mesmo ano, Lobato anuncia a publicação de mais um livro - O Saci - e de "novos na bica", Fábulas de Narizinho (1921) e O marquês de Rabicó (1922) (LOBATO, 2010, p. 463). Seu sucesso como editor e escritor era traduzido em números nunca antes vistos no mercado editorial brasileiro. 
A preocupação com a literatura infantil, porém, não se limitava à publicação de obras próprias. Em junho de 1921, Lobato convida Rangel a participar de uma nova empreitada: adaptações de clássicos infantis em uma linguagem mais atraente para as crianças. Segundo ele, livros escritos em língua mais "desliteraturizada":

Quem sabe pode e quer você empreitar um serviço de que precisamos? Pretendemos lançar uma série de livros para crianças, como Gulliver, Robinson etc., os clássicos, e vamos nos guiar por umas edições do velho Laemmert, organizadas por Jansen Müller. Quero a mesma coisa, porém com mais leveza e graça de língua. Creio até que se pode agarrar o Jansen como "burro" e reescrever aquilo em língua desliteraturizada porque a desgraça da maior parte dos livros é sempre o excesso de "literatura" (LOBATO, 2010, p. 466-467).

Interessante a notar é que, nesse mesmo período, de 1917 a 1921, em meio a toda essa incessante profusão de ideias e projetos para a recepção infantil, que inclui o lançamento de sua obra inaugural para crianças, $A$ menina do narizinho arrebitado (1920), Lobato encontra espaço e oportunidade para publicar seus primeiros livros de contos: Urupês (1918), Cidades mortas (1919) e Negrinha (1920). Neste último, chamanos atenção o conto homônimo justamente por trazer uma criança como protagonista, porém em uma abordagem totalmente oposta àquela que o autor procura criar em seu universo infantil. 


\subsection{Um filhote de livro}

Desde a publicação de seus primeiros textos, Monteiro Lobato já apresentava uma originalidade peculiar, que se mostrou indiscutível mais tarde, nas suas obras destinadas às crianças.

De acordo com Marisa Lajolo, em obra biográfica sobre o autor (2000), os primeiros contos ficcionais de Lobato nasceram, de fato, quando, assumindo a fazenda de seu avô, o jovem empreendedor mostrou-se revoltado com as impropriedades da política econômica que não favorecia à lavoura. Por meio de seus escritos, era possível perceber sua intrepidez em criticar o "coro patriótico e ufanista" em voga nos anos 1910-1920, ressoando "toda a insatisfação dos velhos fazendeiros paulistas que [...] consideravam-se lesados pela política em vigor" (LAJOLO, 2000, p. 25-26).

Com o texto intitulado "Velha Praga" (1914)124, uma crítica às queimadas propositais, praticadas nas matas no entorno às fazendas, Lobato ganhou "projeção nacional". Para Zelia Cardoso ${ }^{125}$, o escritor, "que durante anos a fio escrevera em surdina", com artigos e contos publicados sob pseudônimo, "alça seu voo para tornarse um dos expoentes mais importantes da literatura brasileira da época" (CARDOSO, 1983, p. 28).

0 artigo publicado em seguida, "Urupês", que integraria mais tarde o livro homônimo (Urupês, 1918), tornou a figura do Jeca Tatu conhecida em todo o Brasil, evidenciando o caráter regionalista de Lobato. Construída a partir da própria observação do autor nos tempos em que morou na Fazenda Buquira, a "imagem do caipira, numa fotografia sem retoque" vem substituir "a ideia romântica do caboclo forte e audaz", sendo "produto de longa convivência com o homem da zona rural" (CARDOSO, 1983, p. 28-29).

Para Alfredo Bosi, apesar das controvérsias, Lobato foi "um intelectual participante que empunhou a bandeira do progresso social e mental de nossa gente"

\footnotetext{
124 Texto publicado originalmente no jornal O Estado de São Paulo.

125 Zelia de Almeida Cardoso, Doutora em Letras Clássicas e Livre-Docente em Literatura Latina (USP), autora do livro O romance paulista no século XX (1983).
} 
(BOSI, 1990, p. 242). 0 crítico discorre sobre o "pendor" do autor paulista "para a militância", afirmando que:

na medida em que a cultura do imediato pós-guerra refletia o aprofundamento de um filão nacionalista, o criador do Jeca mantinha bravamente a vanguarda; com efeito, depois de Euclides e de Lima Barreto, ninguém melhor do que ele soube apontar as mazelas físicas, sociais e mentais do Brasil oligárquico e da I República, que se arrastava por trás de uma fachada acadêmica e parnasiana. Nessa perspectiva, Lobato encarnou o divulgador agressivo da Ciência, do progressismo, do "mundo moderno", tendo sido um demolidor de tabus, à maneira dos socialistas fabianos, com um superávit de verve e de sarcasmo (BOSI, 1990, p. 242, grifos do autor).

Lajolo também destaca em Lobato o "espírito empreendedor moderno e vigoroso que ao longo de toda a sua vida vai marcar sua atividade de empresário da cultura" (2000, p. 28), retratando da seguinte forma como o primeiro livro de contos do autor (Urupês, 1918) foi recebido pelo público:

O lançamento de Urupês é um sucesso sem precedentes. Tem excelente aceitação, esgota em um ano milhares de volumes e confirma a importância de um esquema alternativo de distribuição de livros, uma vez que a rede de livrarias do país era [...] muito precária (LAJOLO, 2000, p. 30).

João Luís Ceccantini126 exalta ainda o impacto de Urupês no cenário editorial e literário brasileiro do início do século, tornando a obra inaugural de Lobato um "estrondoso fenômeno", sem precedentes em nossa literatura:

\footnotetext{
126 João Luís Ceccantini. Professor Assistente Doutor da UNESP; especialista em Literatura Brasileira, desenvolvendo pesquisa em literatura infantil e juvenil, leitura, formação de leitores, literatura e ensino, Monteiro Lobato e literatura brasileira contemporânea em geral.
} 
Desde seu lançamento, Urupês configurou-se como um estrondoso fenômeno editorial e cultural, para o qual é difícil encontrar equivalente no universo literário de nosso país. 0 brutal impacto de Urupês à sua época, a maneira espetacular como mobilizou a opinião pública e a intelectualidade brasileira, a quantidade de artigos sobre a obra publicados nos mais variados veículos da imprensa e as polêmicas que criou fizeram história. Do mesmo modo, a extraordinária vendagem alcançada pela obra, objeto de altas tiragens, atípicas para os padrões de seu tempo, e de edições as mais variadas, utilizando-se de recursos gráfico-editoriais inovadores (capas coloridas, ilustrações, paratextos etc.), constituiu um divisor de águas do mercado editorial brasileiro (CECCANTINI, 2014, p. 44).

Dois anos mais tarde, em 1920, Monteiro Lobato viria a publicar Negrinha, livro composto inicialmente por seis $\operatorname{contos}^{127}$ e assim definido pelo próprio autor, em carta a Rangel:

Lanço meu agora um verdadeiro filhote de livro - Negrinha, para fazer uma experiência: se vale mais a pena lançar "livros inteiros" a 4 mil-réis ou "meios livros" a 2.500 réis. A simples lógica do raciocínio não vale em casos desses; temos de experimentar (LOBATO, 2010, p. 456).

Na carta, Lobato parece mais interessado no seu viés empreendedor de editor do que propriamente no aspecto literário de seu livro. De qualquer modo, o conto "Negrinha" tornou-se um "clássico" da literatura brasileira não apenas por trazer como protagonista uma criança, como já ocorrera antes em Urupês e Cidades Mortas ${ }^{128}$, mas sobretudo por retratar uma criança negra, quando os resquícios do regime monárquico e a herança escravocrata ainda eram bastante evidentes em nossa sociedade.

\footnotetext{
127 A primeira edição de Negrinha (1920) era composta dos seguintes contos: "Negrinha"; "Fitas da vida"; "O drama da geada"; "O bugio moqueado"; "O jardineiro Timóteo" e "O colocador de pronomes". Embora publicado somente em 1920, o conto "Negrinha” teria sido escrito por Lobato em 1917. 128 Os personagens infantis nas obras adultas de Lobato serão descritos mais à frente.
} 
Bosi define a obra como "um livro heterogêneo onde reponta com maior insistência o documento social acompanhado do costumeiro sentimento polêmico e da vontade de doutrinar e reformar" (BOSI, 1990, p. 243).

De acordo com Milena Martins ${ }^{129}$, a primeira e a segunda edições de Negrinha "esgotaram-se rapidamente, somando 12 mil exemplares". E, "apesar do sucesso comercial, a ideia de um livro pequeno foi pouco a pouco deixada de lado" (MARTINS, 2014, p. 118), uma vez que, na segunda edição, foram acrescentados novos contos, e assim ocorreu também nas edições sucessivas, chegando a conter 22 contos na edição de 1946.

Para Cardoso, "Negrinha é uma coletânea onde se alinham narrativas de alto teor dramático, como o conto-título". Para a autora, considerando apenas a obra adulta do escritor, Negrinha, Urupês e Cidades Mortas "compõem aquilo que a crítica especializada tem considerado a melhor contribuição de Monteiro Lobato para a ficção brasileira, em geral, e para a paulista, em particular" (CARDOSO, 1983, p. 30). Desse modo, no plano da narrativa ficcional, os contos contidos nessas obras "representam não só uma das primeiras tentativas de novidade no âmbito da renovação literária", mas também "revelam o escritor sagaz que vê e relata e que, assim procedendo, atinge o grande público sem cair na trivialidade e nas concessões" (p. 32).

No texto intitulado "A modernidade em Monteiro Lobato", Marisa Lajolo afirma que, nos contos de seus três livros inaugurais, "Lobato desanca com humor violento a literatice acadêmica, o alambicado parnasiano, a importação de modelos do escrever e do fazer literatura" (LAJOLO, 1983, p. 47). Para a autora,

sua narração oraliza-se e, não raras vezes, é emitida por um narrador participante ou testemunha dos casos narrados. $\mathrm{O}$ ambiente popular em que se movem tais narrativas afiança, nesta situação de oralidade na narrativa, sua desliteralização (LAJOLO, 1983, p. 47).

\footnotetext{
129 Milena Martins é Mestre em Letras e Doutora em Teoria e História Literária (Unicamp). É professora do curso de Letras e do Programa de Pós-Graduação em Estudos Literários da Universidade Federal do Paraná.
} 
Já no ensaio "Lobato: um homem da República Velha", ao contrário do retrocesso que o título sugere, Carlos Jorge Appel ${ }^{130}$ apresenta-nos um autor dividido: "passadista e conservador", por um lado, e "revolucionário, destruidor de falsos ídolos e ideias", "empreendedor moderno, ligado às exigências de seu tempo", por outro. Para o crítico, no conto "Bugio moqueado", por exemplo, presente na coletânea Negrinha, descobre-se "outro escritor, em sintonia com os ideais do progresso tecnológico", mostrando-se uma grande diferença de estilo de linguagem entre esse livro e seus antecessores, Urupês e Cidades Mortas. Para ele,

nos contos de Negrinha, a linguagem é ágil, lembrando o movimento dos diálogos cinematográficos. 0 humor combate o sentimentalismo da obra anterior, e o descritivismo cede lugar a um processo narrativo tenso e dramático (APPEL, 1983, p. 29).

No conto "Negrinha" estão presentes a ironia e o sarcasmo, além da agilidade linguística. Para Lajolo, o "diálogo" presente no conto se estabelece desde o seu princípio, entre o narrador e seus leitores:

a protagonista é apresentada por um narrador que parece estar em diálogo constante com seus leitores, antecipando-lhes expectativas, alimentando-as, satisfazendo ou não a elas (LAJOLO, 2011, p. 239).

Curiosamente, a publicação de Negrinha, "filhote de livro", ocorre no mesmo ano em que o livro precursor de toda a obra infantil de Lobato também seria publicado: A menina do narizinho arrebitado (1920). Ambas as narrativas apresentam em seus primeiros parágrafos uma órfã de sete anos, e as duas protagonistas são tratadas por

${ }^{130}$ Carlos Jorge Appel, escritor e crítico literário. 
apelidos $^{131}$. Porém as coincidências param por aí: enquanto a neta de Dona Benta desfruta no ilusório universo do Sítio do Picapau Amarelo a infância de brincadeiras e imaginação que toda menina sonhadora gostaria de ter, à personagem Negrinha essa mesma infância é simplesmente negada.

Negrinha não é, porém, a única personagem criança encontrada nas obras adultas de Monteiro Lobato. Antes dela teríamos Anica ("Bucólica”), Pingo d'Água ("A colcha de retalhos") 132 e Pernambi ("A vingança da peroba"), em Urupês, e Pedrinho ("Pedro Pichorra"), em Cidades Mortas. Encontraríamos ainda o aspirante a engraxate também Pedrinho - em "O fisco"133, além do menino Luisinho, fruto da imaginação do narrador, em "Duas cavalgaduras"134, contos incluídos posteriormente na coletânea Negrinha.

No entanto, os personagens infantis das obras adultas de Lobato encerram em suas curtas trajetórias uma grande desesperança, ao contrário do que encontramos nas crianças representadas em suas obras infantis.

Em uma análise comparativa das personagens infantis dos contos para adultos e das histórias para crianças de Monteiro Lobato, Cilza Bignotto ${ }^{135}$ revela algumas semelhanças e diferenças entre os protagonistas dos contos e de toda a obra infantil do escritor. Entre as semelhanças, “destacam-se a faixa etária, o cenário das narrativas e o papel fundamental da imaginação infantil, tanto nas histórias dirigidas para adultos como naquelas produzidas para crianças” (BIGNOTTO, 1999, p. 7). Já as diferenças são bem mais acentuadas. Utilizando como corpus para a obra adulta de Lobato os já citados contos de Urupês, Cidades Mortas e Negrinha, a autora afirma que,

\footnotetext{
${ }^{131}$ Embora à personagem-título do livro infantil seja primeiramente atribuído um nome próprio, Lúcia, a personagem fica conhecida mesmo pelo apelido "Narizinho". Cabe ressaltar a diferença quanto à afetividade dos apelidos: enquanto "Narizinho" revela-se uma forma carinhosa de tratamento, "Negrinha" parece configurar desprezo.

${ }^{132}$ Em "Colcha de retalhos", aparece a menina Maria das Dores, apelidada de Pingo d'Água, já com seus catorze anos. Como a personagem é apenas mencionada e não tem ações significativas na trama, esse conto não será analisado.

133 "O fisco" foi composto em 1918 e publicado primeiramente na Revista do Brasil, com o título de "O imposto único" (POLINESIO, Julia Marchetti. O conto e as classes subalternas. São Paulo, Annablume, 1994, p. 59). Ainda com o título "O imposto único", passou a integrar a segunda edição de Negrinha, de 1922. Com o título "O fisco", só apareceu na edição de 1946.

${ }^{134}$ Esse conto foi inicialmente publicado na coletânea $O$ macaco que se fez homem (1923), que teve uma única edição. Posteriormente os contos dessa coletânea foram distribuídos nas edições de Cidades Mortas e Negrinha, tendo esse conto passado a fazer parte do último (MARTINS, 2014, p.118-121).

${ }^{135}$ Cilza Carla Bignotto. Mestre e Doutora em Teoria e História Literária (UNICAMP). É professora de Teoria Literária e Literatura Brasileira na Universidade Federal de Ouro Preto (MG).
} 
"enquanto na obra escrita para adultos as personagens infantis têm destinos trágicos são espancadas, torturadas, mortas", nos livros dirigidos às crianças "as personagens infantis são protegidas, amadas e, principalmente, incentivadas a brincar e a utilizar a imaginação para descobrir e interpretar o mundo" (p. 7).

Assim, na obra infantil,

a situação inicial de Pedrinho e Narizinho é a melhor possível: possuem uma família amorosa, são bem alimentados, brincam e estudam. 0 espaço da ação é bonito e as personagens infantis podem mexer em tudo: plantam flores, erguem mastro de São João, quebram cegonha de louça, fazem bolinhos. Finalmente, a individualidade das crianças é respeitada, e no Sítio do Picapau Amarelo cada uma tem seu próprio quarto (BIGNOTTO, 1999, p. 117).

Enquanto isso, na obra adulta, a situação é bem diferente: Anica, de "Bucólica”, é uma menina de sete anos, assim como Narizinho. Porém é uma criança com deficiência, tratada pelo narrador por "aleijadinha”, "passarico enfermo". Quando aparece na trama, já está morta. 0 pai, “um bobo que anda pelo cabresto", alcoólatra, está cuidando do enterro. A mãe, Nhá Veva, "papuda" de "ruim fama", não demonstra qualquer emoção pela morte da filha. De acordo com Inácia, ama que cuidava da menina, a mãe era "má como a irara", e não perdia oportunidade de rogar pragas à criança. De acordo com uma testemunha, o moleque Zico, Anica morrera de sede na véspera, no único dia em que Inácia não pôde ir trabalhar devido a um temporal. Quando a ama chegou, a menina jazia já sem vida em uma esteirinha na cozinha (LOBATO, 2004b, p. 102-105).

Protagonista de "O fisco", Pedrinho, "nove anos, franzino, doentio, sempre mal alimentado e vestido com os restos das roupas do pai", que nasceu "sem ser consultado", em nada lembra o personagem homônimo ${ }^{136}$ do Sítio do Picapau Amarelo. Talvez apenas na idade e na sua aptidão para menino sonhador, por imaginar que conseguiria, com uma caixa de engraxate nas mãos, resolver toda a situação financeira da família.

136 Pedrinho, primo de Narizinho. Não figurava na primeira versão de A menina do narizinho arrebitado (1920). Apareceu pela primeira vez em Reinações de Narizinho (1932). 
Após ouvir à noite o desabafo dos pais, que já projetavam dias melhores quando o primogênito pudesse trabalhar, resolve fazer-lhes uma surpresa e antecipar sua entrada no mercado, tomando o rumo como engraxate. Naquela noite mesmo já imaginava os níqueis a pingar em seu bolso, o espanto da mãe, a "cara admirada do pai, o regalo da criançada com a perspectiva da ração em dobro". No dia seguinte, ao finalizar a caixa "tosca e mal ajambrada", sentiu um "apogeu de felicidade vitoriosa". De acordo com o narrador, "era como um sonho - e sonhando saiu para a rua". Porém o sonho não durou nem um dia. Após a tentativa frustrada de Pedrinho ${ }^{137}$, que trouxe mais dívidas à família do que a esperada recompensa, no desenlace do conto, enquanto a mãe raspa as economias do pote para pagar a propina do fisco, o menino acaba levando uma violenta surra do pai (LOBATO, 1959b, p. 53-65).

No conto "Duas cavalgaduras", o narrador constrói todo um "drama infantil" para tentar entender a presença de um coelhinho de pelúcia na vitrine de um sebo. $\mathrm{Na}$ imaginação do narrador, aquele coelhinho pertencera a Luisinho, "um menino de poucos anos, filho de pais miseráveis", pai, alcoólatra, e mãe, tísica. A família passa fome, é preciso vender tudo para comprar pão. E "a triste criança, sempre de olhos assustados, a criar-se um mundinho de sonhos para refúgio da almazinha que teima em ser alma”. Quando o pai desaparece e a mãe cai doente, a saída é vender o único brinquedo do menino. "A criança relutou, mas cedeu ao cabo de muitas lágrimas. A fome impunha-lhe aquele sacrifício: trocar o seu tesouro por um pão". O narrador imagina toda essa trama, porém a fictícia história de Luisinho esconde na verdade outro triste acontecimento: a morte do enjeitado Antoninho, vítima de uma gripe, com apenas sete anos de idade. 0 coelhinho fora seu último brinquedo (LOBATO, 1959c, p. 189-200).

Outros personagens infantis de Lobato, os meninos Pedrinho, de "Pedro Pichorra" e Pernambi, de "A vingança da peroba", nada têm de infantil. Desde pequenos são tratados pelos respectivos pais como homens: fumam, bebem, usam "faca de ponta".

Antes de ser dono de uma "sitioca pitoresca" e pai de nove "Pichorrinhas", Pedro Pichorra era apenas Pedrinho. Aos onze anos, já trabalhava duro o menino, debulhando espigas no milharal e atrelando a égua. Também já fumava, preferindo, "em matéria de fumo, o forte, bem melado". E tinha acabado de realizar "o sonho de toda

\footnotetext{
${ }^{137}$ Sem que houvesse conseguido nem mesmo um freguês, o menino é pego pelo "fisco" por trabalhar sem licença e a família precisa pagar uma alta multa.
} 
criança da roça - a faca de ponta". Recebera-a do próprio pai, como "diploma de virilidade" (LOBATO, 1981b, p. 29-33).

Já Pernambi, apelido de José Benedito, um "passarico desta alturinha, apesar de bem entrado nos sete anos", não teve a mesma "sorte", pois nem chegou a atingir a idade adulta. Como único menino em um lar só de mulheres, o franzino garoto era tratado como homem. Pertencia o Nunes, o pai, "à classe dos que decaem por força de muita cachaça na cabeça e muita saia em casa". Sua família era "um rosário de oito mariquinhas de saia comprida”. "Tanta mulher em casa amargava o ânimo do Nunes, que nos dias de cachaça ameaçava afogá-las na lagoa como se fossem uma ninhada de gatos". A saída era mimar Pernambi, o único filho homem. Desde pequeno, o menino "bebia e fumava muito sorna, com ares palermas de quem não é deste mundo. Também usava faca de ponta à cinta". Porém um dia, embebedado pelo pai - que também estava alcoolizado -, acidenta-se no monjolo da família e morre sob o pilão (LOBATO, 2004c, p. 55-69).

Desse modo, percebe-se que o drama familiar e a tragédia são motes para todos os contos adultos de Lobato em que personagens infantis têm destaque, ao menos no que se refere às obras citadas ${ }^{138}$.

Anica, Negrinha e Pernambi não chegam à vida adulta: morrem por negligência e falta de cuidados. Todos têm sete anos. 0 conto "O fisco" termina com o menino Pedrinho levando uma surra do pai, quando seu maior erro foi tentar ajudar a família. Luisinho, personagem da imaginação do narrador, precisa se desfazer do coelhinho de pelúcia, seu único companheiro, para poder comer e alimentar a mãe doente. No mesmo conto, o verdadeiro dono do brinquedo, Antoninho, havia morrido de gripe. Já o "companheiro" de Pedro Pichorra não era um inofensivo coelhinho de pelúcia, mas uma faca de ponta, que lhe fora dada aos onze anos e tomada dias depois. 0 "diploma de virilidade" foi confiscado como uma forma de humilhar o menino, que havia demostrado medo de saci em uma viagem à noite sozinho a cavalo, o que lhe rendeu para toda a vida a zombaria e a alcunha "Pichorra", atribuída a ele pelo próprio pai.

138 Aos contos das coletâneas Urupês, Cidades mortas e Negrinha. 
De acordo com Bignotto, “a miséria está presente em todas as famílias das personagens infantis dos contos para adultos" de Lobato (1999, p. 120):

a mãe de Negrinha é escrava, os pais de Pedrinho (O Fisco) são "escravizados". As crianças passam fome, são "doentias", "atrofiadas", "mal vestidas". Moram em casebres e não estudam. Negrinha e Pedrinho Pichorra trabalham. Os pais de Pernambi e de Pedrinho (O Fisco) esperam o momento em que seus filhos irão trabalhar. Anica, por não poder trabalhar, é rejeitada pela mãe. A miséria não deixa espaço para brincadeiras, tanto que Luisinho precisa vender o único brinquedo para comprar comida (BIGNOTTO, 1999, p. 120).

Para Lajolo,

as histórias do pica-pau amarelo parecem fazer do sítio de Dona Benta um modelo social para o Brasil posterior a 1930, o que de certa forma dá à obra infantil lobatiana papel de relevo no projeto de formação, reconstrução ou modernização do país em que se empenha o escritor. Fica, por isso, sugestivo observar como a presença de crianças em obras não infantis do mesmo Lobato muda de registro e traz para o texto lobatiano uma tecla amarga de desesperança [...] (LAJOLO, 2011, p. 239).

É o que procuraremos atestar a seguir, com a análise do conto "Negrinha". 


\section{4 "Negrinha", a menina que desconhecia a infância}

Sem qualquer introdução contextualizando época ou local ou mesmo descrevendo o ambiente ou ação prévia, o narrador do conto "Negrinha"139 propõe a apresentação da personagem-título de maneira bem direta, sem rodeios ou atenuações:

Negrinha era uma pobre órfã de sete anos. Preta? Não; fusca, mulatinha escura, de cabelos ruços e olhos assustados (LOBATO, 1959, p. 3).

Nota-se no curto parágrafo sua preocupação em declarar rapidamente a orfandade e a idade da protagonista, e em seguida revelar sua cor de pele, estabelecida em seu próprio nome - "Negrinha" - e caracterizada pelos vocábulos "fusca" e "mulatinha escura". 0 uso do adjetivo "pobre" associado ao termo "órfã" nos fornece sua dupla conotação: aquela que é digna de piedade e ao mesmo tempo desprovida de recursos ou riquezas. E o advérbio "não" anuncia diretamente ao leitor o tom que permeará toda a narrativa: a negação.

A caracterização física da menina é realizada ao longo do texto por meio de adjetivos e expressões, tais como "magra, atrofiada, com os olhos eternamente assustados" (p. 4), com o corpo "tatuado de sinais, cicatrizes, vergões" (p. 5); "carnezinha de terceira - uma miséria, trinta quilos mal pesados" (p. 12). Como oposição à magreza, à pobreza e à insignificância de Negrinha, o narrador apresenta a opulência, a fartura e a abundância de dona Inácia, valendo-se muitas vezes da ironia e do sarcasmo para descrever tanto seus aspectos físicos como morais:

139 Usaremos para fins de citação esta edição de 1959, 9a edição das Obras completas de Monteiro Lobato, Vol. 3. Em todas as citações da obra a ortografia foi atualizada conforme o acordo ortográfico de 2009. 
Excelente senhora, a patroa. Gorda, rica, dona do mundo, amimada dos padres, com lugar certo na igreja e camarote de luxo reservado no céu. Entaladas as banhas no trono (uma cadeira de balanço na sala de jantar), ali bordava, recebia as amigas e o vigário, dando audiências, discutindo o tempo. Uma virtuosa senhora em suma - "dama de grandes virtudes apostólicas, esteio da religião e da moral”, dizia o reverendo. Ótima, a dona Inácia (LOBATO, 1959, p. 3).

0 enredo todo se desenvolve nos aposentos de uma casa grande ${ }^{140}$, de propriedade de dona Inácia, onde a menina vivia "de favor" ou "caridade"141, e era castigada gratuitamente, "por ação ou omissão" (LOBATO, 1959, p. 4), apenas pelo fato de existir. Além de Negrinha e da patroa, outros moradores ali também viviam, bem como empregados, porém não configuram personagens nem mesmo secundários na trama; são apenas citados no discurso do narrador como os "grandes" ou "os da casa", ou ainda têm sua presença deduzida pelas conjugações que ocorrem na terceira pessoa do plural ${ }^{142}$.

A época em que a trama se passa não é precisamente delimitada pelo narrador, mas estima-se que ocorra em um período relativamente curto após a abolição da escravatura, e, desse modo, próximo daquele em que o próprio conto é escrito ${ }^{143}$, no que se refere especialmente contexto político e social brasileiro. Ou seja, entre os séculos XIX e XX, quando já não havia escravos, mas ex-escravos, filhos de escravos e intensos resquícios da escravatura. Essa constatação pode ser feita logo no início da narrativa, quando se apresenta a menina como nascida "na senzala, de mãe escrava" (LOBATO, 1959, p. 3), ou um pouco adiante, quando o narrador sarcasticamente

\footnotetext{
${ }^{140}$ Embora não haja uma descrição detalhada, a casa mostra-se espaçosa, com citações de quintal, jardim e senzala. As ações desenvolvem-se principalmente na cozinha e na sala, e no final do conto, também no jardim/quintal. A própria dona Inácia define a casa como "grande" em uma fala às sobrinhas: "Mas brinquem, filhinhas, a casa é grande, brinquem por aí afora" (LOBATO, M. Negrinha, p. 8).

1410 termo "caridade" está empregado no sentido irônico, uma vez que a patroa não nutre nenhum sentimento pela menina além do desprezo e do ódio; porém o mesmo termo é usado pela própria dona Inácia, ao apresentar a menina às sobrinhas (Negrinha, p. 8) e pelo padre que a visita, ao saber da patroa "a trabalheira" que dá criar uma órfã (p. 7).

142 "Não compreendia a ideia dos grandes"; [...] não tinha conta o número de apelidos com que $a$ mimoseavam"; "Batiam nele os da casa todos os dias, houvesse ou não houvesse motivo" (LOBATO, 1959, p. 4-5, grifos nossos).

${ }^{143}$ Embora publicado em 1920, o conto foi escrito em 1917, ou seja, aproximadamente 30 anos após a abolição da escravatura.
} 
descreve o desejo de dona Inácia em saciar sua "gana" de dona de escravos que não media esforços para fazer valer sua condição "superior" e não aceitava com naturalidade o "novo regime" então vigente, após a abolição:

\begin{abstract}
A excelente dona Inácia era mestra na arte de judiar de crianças. Vinha da escravidão, fora senhora de escravos - e daquelas ferozes, amigas de ouvir cantar o bolo e estalar o bacalhau. Nunca se afizera ao regime novo - essa indecência de negro igual a branco e qualquer coisinha: a polícia! "Qualquer coisinha": uma mucama assada ao forno porque se engraçou dela o senhor; uma novena no relho porque disse "Como é ruim, a sinhá!"... 013 de Maio tirou-lhe das mãos o azorrague, mas não lhe tirou da alma a gana. Conservava Negrinha em casa como remédio para os frenesis. Inocente derivativo. "Ai! Como alivia a gente uma boa roda de cocres bem fincados!” (LOBATO, 1959, p. 5).
\end{abstract}

Apesar de situar tempo e espaço da narrativa - ainda que indiretamente no caso do tempo -, o narrador faz questão de criar um "não lugar" e um "não espaço" para Negrinha, denotando-os por meio de expressões como "cantos escuros"; "trapos imundos"; "desvão da porta":

Nascera na senzala, de mãe escrava, e seus primeiros anos vivera-os pelos cantos escuros da cozinha, sobre velha esteira e trapos imundos. [...] Órfã aos quatro anos, por ali ficou feito gato sem dono, levada a pontapés. [...] Aprendeu a andar, mas quase não andava. Com pretexto de que às soltas reinaria no quintal, estragando as plantas, a boa senhora punha-a na sala, ao pé de si, num desvão da porta. [...] Negrinha imobilizava-se no canto, horas e horas. [...] Cruzava os bracinhos a tremer, sempre com o susto nos olhos (LOBATO, 1959, p. 3-4).

Desse modo, a menina - que não pertence à casa grande ou à senzala - ocupa esses "não lugares" na narrativa, não lhe cabendo ambientes mais dignos, como quarto, aposento, casa, ou mesmo leito, cama, berço; vocábulos que não lhe dizem respeito. 
Além do "não lugar", Negrinha vive com a condição de "não ser", a começar pela ausência de nome - e sobrenome. A alcunha "Negrinha", empregada durante todo o texto pelo narrador, só é usada também pela própria personagem, no único momento em que lhe perguntam o nome:

- Como é boba, disseram. E você como se chama?

- Negrinha.

As meninas novamente torceram-se de riso [...].

(LOBATO, 1959, p. 9).

Durante toda a narrativa, porém, a protagonista nunca é chamada, no discurso direto, nem mesmo pelo apelido "Negrinha". Nas falas de dona Inácia, no decorrer do conto, os prosônimos utilizados pela senhora para designar a menina são "peste", "pestinha" e "diabo":

- Quem é a peste que está chorando aí?

- Braços cruzados, já, diabo!

- Diga nomes feios aos mais velhos outra vez, ouviu, peste?

- Já para o seu lugar, pestinha! Não se enxerga?

(LOBATO, 1959, p. 3-8).

O narrador ainda faz questão de enumerar vários outros apelidos usados para identificá-la. Nota-se sua ironia declarada na escolha do verbo "mimosear" para referirse à forma como "as pessoas" criavam alcunhas pejorativas para chamar a menina, entre elas, diversos nomes de animais acompanhados ou não de adjetivos que intensificam suas qualidades negativas, além de referências a "sujeira" e "lixo" e termos ligados a espíritos do mal:

Que ideia faria de si essa criança que nunca ouvira uma palavra de carinho? Pestinha, diabo, coruja, barata descascada, bruxa, pata choca, pinto gorado, mosca morta, sujeira, bisca, trapo, cachorrinha, coisa ruim, lixo - não tinha conta o número de apelidos com que a mimoseavam (LOBATO, 1959, p. 9). 
Até sua própria mãe, em sua única fala em todo o texto, não a trata por um nome próprio, ou simplesmente por "filha", ou mesmo por uma palavra carinhosa. Ela ouve da mãe, ainda pequena, a mesma palavra que ouvirá da patroa: "diabo"144.

Para Lajolo, o diminutivo "negrinha" guarda, "no contexto das relações interétnicas da sociedade brasileira, várias e conflituosas conotações, da afetividade ao menosprezo" (LAJOLO, 2011, p. 240). No caso do conto de Lobato, fica claro o último significado, uma vez que não havia qualquer afetividade por parte das pessoas com quem Negrinha convivia que justificasse um apelido carinhoso.

Outro aspecto relevante com relação às negações relacionadas à infância de Negrinha é a sua "não educação". Não nos referimos, neste caso, nem mesmo a uma educação formal, em seus aspectos sociais e cognitivos, como a convivência com outras crianças e o aprendizado das letras e dos números, mas ao desenvolvimento físico inerente ao ser humano, como andar, movimentar-se, falar.

De acordo com o narrador, Negrinha "aprendeu a andar, mas quase não andava" (LOBATO, 1959, p. 4). Ficava sentada, parada, de braços cruzados, nos seus "não lugares", esperando o tempo passar. Também mal falava, seguindo as ordens da patroa: "Sentadinha aí e bico, hein?" (p. 4).

A única faceta da educação que Negrinha conhecia eram os castigos, os beliscões, os puxões de orelha, os "cocres", e as palavras duras, que não lhe serviam de correção ou aprendizado, pois ela "não compreendia a ideia dos grandes", uma vez que "a mesma coisa, o mesmo ato, a mesma palavra provocava ora risadas, ora castigos" (LOBATO, 1959, p. 4). Nem mesmo as mais severas punições - como o ovo fervendo a lhe queimar a boca ${ }^{145}$ - eram aplicadas no intuito de educá-la. De fato, no episódio do ovo, o "erro" de Negrinha foi chamar uma empregada de "peste", alcunha que sempre ouvia dos "grandes" e que, para ela, não configurava erro.

\footnotetext{
${ }^{144} \mathrm{Na}$ única fala atribuída a Cesária, mãe de Negrinha, ela diz: “Cale a boca, diabo!” (p. 4). Poderíamos interpretar o termo "diabo", neste caso, como uma interjeição, e não propriamente um vocativo. Porém a ideia que se passa é a de vocativo, especialmente devido às outras falas presentes no texto.

145 No episódio, uma das cenas mais cruéis relatadas no conto, dona Inácia coloca um ovo fervendo na boca da menina para que ela aprenda a não falar "nomes feios" aos mais velhos. 0 "nome feio" a que se refere a patroa é "peste", alcunha com que a menina era comumente chamada na casa. Na narrativa, Negrinha chamara de "peste" a criada que lhe roubara um pedaço de carne de seu prato de comida.
} 
O narrador cita o crochê como única ocupação que teriam dado à menina, porém a atividade em si não traz qualquer significado ou pretensão de instruí-la a produzir algo, mas é destinada apenas a preencher seu ócio com um "nada palpável" as trancinhas - que, à medida que se espichavam, alongavam também o seu tempo perdido, em que nada de útil ou prazeroso lhe era permitido fazer: "Puseram-na depois a fazer crochê, e as horas se lhe iam a espichar trancinhas sem fim" (LOBATO, 1959, p. 4). Porém o que a divertia no passar das horas do seu "não tempo" não eram as trancinhas, mas o relógio da parede que, de quando em quando, abria e fechava a janela, deixando aparecer o cuco com sua "bocarra vermelha, arrufando as asas" (p. 4).

De fato, a observação do cuco a cada hora de vida que lhe era tolhida tornavase o único "consolo" da menina: "Sorria-se então por dentro, feliz um instante" (p. 4), como se por um momento pudesse se distanciar da vida que diariamente e continuadamente lhe era negada.

Porém no seu rol de negações - não lugar, não tempo, não ser, não aprender, não brincar - ainda caberia uma, que talvez fosse a mais cruel: o "não pertencimento".

A noção de "não pertencimento" começa já no início do conto, com relação à sua etnia: embora seu nome fosse Negrinha, a menina não era negra; muito menos branca: era "fusca", "mulatinha escura", mestiça. Ou seja, na verdade, não pertencia a etnia alguma.

Para Marisa Lajolo, em análise sobre o mesmo conto lobatiano, a negação do narrador à pergunta retórica que ele mesmo faz e responde ("Preta? Não") inscrevem Negrinha "numa identificação à deriva", prolongada e acentuada pelo "ruço do cabelo" (LAJOLO, 2011, p. 240, grifo da autora).

Quanto à sua condição social, Negrinha não era escrava, nem livre, uma vez que não fazia parte da senzala, e tampouco da casa. Era uma "agregada desagregada", sem pertencer a lugar algum, nem mesmo ao universo da humanidade, uma vez que não era criança; era "coisa”, bicho, "gato sem dono"; "peste”, "pestinha”, "diabo".

Para Lajolo, a personagem é toda "construída pela enumeração dos atributos que ela não tem", ou seja, caracterizada especialmente por suas "carências" e "ausências", e não por suas qualidades, por suas ações ou reações. A autora afirma que "a apresentação de Negrinha pelo que ela não tem já se prefigura no adjetivo atrofiada" 
(LAJOLO, 2011, p. 240, grifo da autora), sendo-lhe acrescentadas pouco a pouco pelo narrador outras limitações e privações, como "não andar" e "não compreender".

Negrinha, no entanto, não tem consciência de sua infância negada até conhecer a infância aceita, autorizada e permitida encarnada pelas sobrinhas de dona Inácia, "lindas meninas, louras, ricas, nascidas e criadas em ninho de plumas" (LOBATO, 1959, p. 7):

Do seu canto na sala do trono Negrinha viu-as irromperem pela casa como dois anjos do céu - alegres, pulando e rindo com a vivacidade de cachorrinhos novos. [...] No enlevo da doce ilusão, Negrinha levantouse e veio para a festa infantil, fascinada pela alegria dos anjos (LOBATO, 1959, p. 8).

O "gato sem dono" pela primeira vez na vida vê os "cachorrinhos novos" - e se encanta. Nesta primeira aparição das meninas, quando se compara a outras pessoas de sua idade e de seu tamanho - a outras crianças -, Negrinha se apercebe de que há algo além do "não ser", do "não lugar" do "não viver". Essa consciência, porém, lhe chega aos poucos: primeiro, nota a diferença de acolhimento e recepção de dona Inácia, que agora ri e permite o divertimento das sobrinhas, incentivando-as a brincar, inclusive, contrariando todas as expectativas da órfã de que as visitantes teriam o mesmo tratamento impiedoso que a ela era oferecido:

Mas abriu a boca: a sinhá ria-se também... Quê? Pois não era crime brincar? Estaria tudo mudado - e findo o seu inferno - e aberto o céu? [...] "[...] Brinquem, filhinhas, a casa é grande, brinquem por aí afora. "Brinquem!" Brincar! Como seria bom brincar! - refletiu com suas lágrimas, no canto, a dolorosa martirzinha, que até ali só brincara na imaginação com o cuco (LOBATO, 1959, p. 8). 
Depois do susto inicial que a chegada das meninas e a reação da patroa lhe proporcionaram, Negrinha percebe que existe uma diferença entre as meninas louras e ela - "elas podem; eu não" -, quando, ao tentar aproximar-se para compartilhar a brincadeira e a alegria de ser criança, é colocada pela patroa em seu "devido lugar", por meio de agressões físicas e verbais:

\begin{abstract}
Mas a dura lição da desigualdade humana lhe chicoteou a alma. Beliscão no umbigo, e nos ouvidos o som cruel de todos os dias: "Já para o seu lugar, pestinha! Não se enxerga?" Com lágrimas dolorosas, menos de dor física que de angústia moral - sofrimento novo que se vinha acrescer aos já conhecidos - a triste criança encorujou-se no cantinho de sempre (LOBATO, 1959, p. 8).
\end{abstract}

A essa percepção o narrador dá o nome de "desigualdade humana" (e não apenas social) que "chicoteia a alma" da menina, ferindo ainda mais que o castigo físico. É o início da consciência do não pertencer.

Apesar da primeira reação de dona Inácia frente à possibilidade de ver a "pestinha" feliz a brincar com suas sobrinhas, a piedade enfim encontra lugar no coração da senhora, e Negrinha tem a oportunidade de experimentar, ainda que por pouco tempo, uma infância plena, com direito a carregar uma boneca como se carregasse "um filhinho de anjo":

Negrinha olhou para os lados, ressabiada, com o coração aos pinotes. Que aventura, santo Deus! Seria possível? Depois, pegou a boneca. E muito sem jeito, como quem pega o Senhor Menino, sorria para ela e para as meninas, com assustados relanços d'olhos para a porta. Fora de si, literalmente... Era como se penetrara no céu e os anjos a rodeassem, e um filhinho de anjo lhe tivesse vindo adormecer no colo. Tamanho foi o seu enlevo que não viu chegar a patroa, já de volta. [...] Mas era tal a alegria das hóspedes ante a surpresa estática de Negrinha, e tão grande a força irradiante da felicidade desta, que o seu duro coração afinal bambeou. E pela primeira vez na vida foi mulher. Apiedou-se. [...] 0 que sobreveio foi a coisa mais inesperada do mundo - estas palavras, as primeiras que ela ouviu, doces, na vida: "Vão todas brincar no jardim, e vá você também, mas veja lá, hein?” (LOBAT0, 1959, p. 9-10). 
Há de fato dois tipos diferentes de infância retratadas nesta obra: a infância plena, representada pelas sobrinhas de dona Inácia, e a infância negada, de Negrinha.

Assim, depois de experimentar a infância plena e perceber que "tinha uma alma", Negrinha jamais poderia voltar a ser a mesma "coisa", o mesmo "gato sem dono" de antes. Após viver uma "experiência humana" de infância, "sentia-se outra, inteiramente transformada":

\begin{abstract}
Negrinha, coisa humana, percebeu nesse dia da boneca que tinha uma alma. Divina eclosão! Surpresa maravilhosa do mundo que trazia em si e que desabrochava, afinal, como fulgurante flor de luz. Sentiu-se elevada à altura de ente humano. Cessara de ser coisa - e doravante serlhe-ia impossível viver a vida de coisa. Se não era coisa! Se sentia! Se vibrava! (LOBATO, 1959, p. 11).
\end{abstract}

$\mathrm{Na}$ brincadeira com as sobrinhas de dona Inácia, especialmente ao lhe ser concedido o direito de carregar a boneca, Negrinha deu-se conta de que poderia "ser alguém" diferente daquele "não ser" a que estava habituada. Provou ser humana; provou ser mãe; provou ser mulher. 0 próprio narrador se incumbe de explicitar essa questão:

Varia a pele, a condição, mas a alma da criança é a mesma - na princesinha e na mendiga. E para ambas é a boneca o supremo enlevo. Dá a natureza dois momentos divinos à vida da mulher: o momento da boneca - preparatório, e o momento dos filhos - definitivo. Depois disso, está extinta a mulher (LOBATO, 1959, p. 10).

Assim, no episódio da boneca, Negrinha tem pela primeira vez a oportunidade de experimentar o "jogo da representação". E é por meio desse "jogo" que sua infância - anteriormente negada - se revela. 
Para Johan Huizinga146, mesmo em suas formas mais simples, o jogo é "mais do que um fenômeno fisiológico ou um reflexo psicológico". É uma "função significante, isto é, encerra um determinado sentido", transcendendo as "necessidades imediatas da vida" e "conferindo sentido à ação" (HUIZINGA, 2001, p. 3-4). Em seu estudo sobre inúmeras as formas de jogo, ele define desta maneira o jogo da representação:

A criança representa alguma coisa diferente, ou mais bela, ou mais nobre, ou mais perigosa do que habitualmente é. Finge ser um príncipe, um papai, uma bruxa malvada ou um tigre. A criança fica literalmente "transportada" de prazer, superando-se a si mesma a tal ponto que quase chega a acreditar que realmente é esta ou aquela coisa, sem contudo perder inteiramente o sentido da "realidade habitual" (HUIZINGA, 2001, p. 17).

Desse modo, com a boneca no colo, Negrinha não tinha apenas um brinquedo nas mãos, mas transportava-se ao universo da representação. Com um anjo nos braços, a lhe dizer "mamã", nada mais justo que se imaginasse também anjo, também digna de uma infância completa, como aquela que as meninas louras usufruíam.

Por meio da representação, Negrinha percebeu que tinha uma alma; que tinha desejos e vontades. Porém, sem a boneca, sem o encantamento, sem o brinquedo e a ilusão, não seria mais capaz de viver como antes.

Walter Benjamin ${ }^{147}$, analisando a obra de Karl Gröber sobre uma história do brinquedo, faz importantes reflexões sobre o brinquedo e o brincar. Em uma de suas revelações, Benjamin afirma que a grande lei que rege o mundo da brincadeira, sobretudo para a criança, é a "lei da repetição".

Sabemos que a repetição é para a criança a essência da brincadeira, que nada lhe dá tanto prazer como "brincar outra vez". A obscura compulsão de repetição não é menos violenta nem menos astuta na brincadeira que no sexo. Não é por acaso que Freud acreditava ter descoberto nesse impulso um "além do princípio do prazer". Com

146 Johan Huizinga (1872-1945). Professor e historiador holandês.

147 Walter Benjamin (1892-1940). Ensaísta, crítico literário, filósofo e sociólogo. 
efeito, toda experiência profunda deseja, insaciavelmente, até o fim de todas as coisas, repetição e retorno, restauração de uma situação original, que foi seu ponto de partida. "Tudo seria perfeito, se pudéssemos fazer duas vezes as coisas": a criança age segundo essas palavras de Goethe. Somente, ela não quer fazer a mesma coisa apenas duas vezes, mas sempre de novo, cem e mil vezes! (BENJAMIN, 1994, p. 252-253).

No conto lobatiano, quando as férias terminam e as sobrinhas de dona Inácia partem levando consigo a boneca, a repetição da brincadeira torna-se impossível para Negrinha. Assim, a "essência da brincadeira" e o "brincar outra vez" morrem na ausência do brinquedo, o que acaba desencadeando frustração, melancolia e desassossego na alma da menina.

Mesmo que dona Inácia já não a incomodasse tanto e mesmo que a nova criada lhe amenizasse a vida, a tristeza e a nostalgia tomaram conta de Negrinha, tirando-lhe a fome, as expressões, e até o "susto nos olhos". Conforme o próprio narrador descreve, "aquele dezembro de férias, luminosa rajada de céu trevas adentro do seu doloroso inferno, envenenara-a" (LOBATO, 1959, p. 11).

No delírio que precedeu sua morte, Negrinha estava rodeada de bonecas louras e anjos, numa "farândola do céu". E sentia-se querida, amada, "abraçada, rodopiada". Não à toa a última imagem que a menina teria visto em seu devaneio (ou não) era a do cuco, seu único companheiro na fantasia e na brincadeira. Porém na derradeira visão, a ave não mais batia as asas, e lhe desbotava a cor da garganta, denotando o desaparecimento simultâneo tanto da menina como da sua ilusão. Corpo e alma se esvaindo em trevas.

A morte de Negrinha, no desenlace do conto, sem motivo aparente de enfermidade física, é explicada pelo próprio narrador: "essa consciência a matou". Consciência de que poderia ter uma infância, e não tinha. Consciência de uma infância negada. 
"É o menino que revela o homem".

Gilberto Freyre (1921) 
Capítulo 3

"Verdes anos": reminiscências de um menino de engenho 


\section{CAPÍTULO 3}

\section{"Verdes anos": reminiscências de um menino de engenho}

Chamei de verdes anos os tempos da minha primeira infância. E em livros de memórias procurei reter tudo o que ainda me resta daquela "aurora", que para o poeta Casimiro fora a das saudades, dos campos floridos, das borboletas azuis. Em meu caso as borboletas estiveram misturadas a tormentos de saúde, a ausência de mãe, a destemperos de sexo. E tantos espantos alarmaram os meus princípios que viriam eles me arrastar as tristezas que não deviam ser as de um menino ${ }^{148}$.

José Lins do Rego

\subsection{José Lins do Rego: infância e memória}

Considerado por estudiosos e críticos um dos mais importantes romancistas brasileiros do século XX, José Lins do Rego (1901-1957) integrou o grupo de autores regionalistas nordestinos que despontaram no período de maturação do Modernismo, a partir dos anos $1930^{149}$.

148 Trecho do prefácio do autor à primeira edição do romance autobiográfico Meus verdes anos, (REGO, 1956, p. 5).

149 De acordo com Candido \& Castello, "a ficção regionalista nordestina, cujas raízes sobem a Franklin Távora, passando por Rodolfo Teófilo e Domingos Olímpio, entra numa fase nova em 1928 com $A$ bagaceira, de José Américo de Almeida [...]. Em 1930 aparece e tem grande êxito O Quinze, de Rachel de Queiroz. Ambos possuíam cunho regional e social, voltando-se para problemas como a condição e os costumes do trabalhador rural, a seca, a miséria. Na mesma linha, surgem [...] Os Corumbas, de Amando Fontes, e Cacau, de Jorge Amado [...], Menino de Engenho, de José Lins do Rego, e Caetés, de Graciliano Ramos. E estava lançada uma das correntes mais poderosas da nossa literatura, que chamamos de regionalista para simplificar e nos conformamos ao uso, mas que em muitos dos seus produtos se desprende completamente dos elementos pitorescos, do dado concreto, da vivência social e telúrica da 
A epígrafe que abre este capítulo, retirada do prefácio da sua última obra, Meus verdes anos (1956), publicada um ano antes de sua morte, facilmente poderia ser atribuída a Menino de engenho (1932), seu romance de estreia, tal a consonância entre a infância do autor, revisitada em seu livro de memórias ${ }^{150}$, e a do personagem Carlinhos, protagonista e narrador do seu livro inaugural.

Acerca dessa correspondência, Ivan Junqueira ${ }^{151}$, em estudo crítico sobre a vida e obra do romancista paraibano, ratifica essa percepção, alertando o leitor, contudo, que não tome a afirmação de modo literal, "ao pé da letra":

Já se disse - e não sem alguma razão - que Lins do Rego teria escrito "duas vezes" o mesmo livro, a cuja primeira versão deu ele o título de Menino de engenho, batizando a segunda de Meus verdes anos. É claro que o leitor não deverá jamais tomar esta afirmação ao pé da letra, tanto assim que tivemos o cuidado de aspeá-la. Mas o fato é que os dois livros se tangenciam intimamente enquanto florações quase contíguas de uma única e mesma matriz memorialística, induzindo-nos à suposição de que o escritor agenciou aqui um curioso processo de desdobramento da reminiscência, entretecendo como que duas formas de discurso confessional: uma que parte do registro da memória e cria, liricamente, todo um universo ficcional, alongando assim "o passado no presente"; $\mathrm{e}$ outra que se elabora ao nível de uma decodificação operada a partir de texto anterior cuja matéria-prima lhe é comum (JUNQUEIRA, 1981, p. 424).

Entretanto, apesar da existência de um consciente diálogo aberto entre Menino de engenho e Meus verdes anos, o crítico chama a atenção para a diferença na intencionalidade de cada obra: a primeira, um romance ficcional, que emprega a memória "a serviço da imaginação", e a segunda, "uma memória que se pretende apenas enquanto testemunha ocular da história, de uma história que ela apenas registra, mas não reinventa" (JUNQUEIRA, 1981, p. 424):

região. Na maioria dos livros, porém, esta existe como enquadramento expressivo, dando um peso de realidade e um elemento de conviç̧ão". CANDIDO \& CASTELLO, 1968, p. 28.

1500 próprio autor coloca entre parênteses o subtítulo "Memórias", após o título "Meus verdes anos".

${ }^{151}$ Ivan Junqueira (1934-2014). Jornalista, poeta, ensaísta e crítico literário. 
se é verdade que Lins do Rego escreveu "duas vezes" o mesmo livro, também o é a circunstância de que os haja escrito com intenções inteiramente distintas. A Meus verdes anos falta por completo qualquer indício de autêntica urdidura ficcional, ao passo que, no Menino de engenho, se o ponto de partida é a memória, decerto não será ela o ponto de chegada (JUNQUEIRA, 1981, p. 424).

Também na análise de Luciano Trigo ${ }^{152}$, José Lins conta, “a partir de uma matéria-prima comum, duas vezes a mesma história” (TRIGO, 2002, p. 33). Para ele, "Meus verdes anos é prova cabal de que os três primeiros romances do açúcar153 constituem uma autobiografia disfarçada do autor" (p. 32):

há trechos inteiros que são quase uma repetição de Menino de engenho, e certamente os dois livros são movidos pelo mesmo ímpeto de passar a limpo a infância e a adolescência, fazendo um resgate proustiano do passado (TRIGO, 2002, p. 32).

A infância é, de fato, fase de grande importância na vida e na carreira do homem e do escritor José Lins do Rego. Não por acaso seu primeiro romance aborda essa temática, narrando a história de um menino que - assim como ocorrera com o próprio autor - foi levado a viver no engenho do avô após a morte da mãe.

Para José Aderaldo Castello, em um de seus mais completos estudos sobre a vida e obra de José Lins do Rego ${ }^{154}$, avaliando o fato de o romancista ter sido criado pelo avô materno - um "senhor de engenho" - e pela tia Maria, "que lhe substituiu a afeição da mãe perdida muito cedo", é "nessas condições que se fixam", durante a fase da infância do autor

\footnotetext{
${ }^{152}$ Luciano Trigo. Escritor, crítico literário, jornalista, tradutor e editor. Venceu o prêmio José Lins do Rego da Academia Brasileira de Letras em 2002.

1530 autor refere-se a Menino de Engenho (1932), Doidinho (1933) e Banguê (1934).

${ }^{154}$ CASTELLO, J. A. José Lins do Rego: Modernismo e Regionalismo. São Paulo, Edart, 1961.
} 
os elementos e valores fundamentais que dão origem à sua obra de ficção. [...] Podemos afirmar [...], em generalização inicial, que a fonte do conteúdo psicológico de sua obra é a experiência acumulada nos seus "tristes verdes anos", na condição peculiar em que se encontrou junto aos avós e tios maternos, com o regime de vida que lhe foi imposto em virtude da asma, que o atormentava frequentemente, e com as antecipações sexuais, dolorosas (CASTELLO, 1961, p. 71-72).

Para o crítico, o citado prefácio de Meus verdes anos, apesar das restrições que a afirmação requer, "vale como o mais franco reconhecimento, pelo próprio autor, da origem indicada de sua obra de ficção". Desse modo, embora a "matéria humana de Menino de Engenho" já fornecesse, inicialmente, "uma visão panorâmica da experiência fundamental do romancista", ela se amplia "com detalhes por ele fixados em páginas de crônicas [...] como a atestar uma presença avassaladora na memória, forçando-o, sem cessar, a idas e vindas", o que justificaria "as repetições frequentes na obra que escreveu" (CASTELLO, 1961, p. 72-74).

Porém, além dos aspectos memorialísticos que emanam de Menino de engenho e de outros romances do autor ${ }^{155}$, Castello também atribui como um marco diferencial em suas obras e em sua carreira a intensa amizade que ele desenvolve desde muito jovem com o sociólogo Gilberto Freyre, e as consequentes e inevitáveis influências literárias e políticas que dele recebe.

De acordo com Castello, bem antes de se tornar romancista, é por meio de Freyre que José Lins "redescobre as cidades do Recife e Olinda, seus arredores, o que havia de mais expressivo e característico em sua paisagem [...]. Com ele vai à capital da Paraíba [...] e daí seguem em passeio pelos engenhos e banguês de parentes" (CASTELLO, 1961, p. 88-89). Com o novo amigo, José Lins estuda a língua inglesa "ao mesmo tempo

\footnotetext{
155 Aspectos memorialísticos são encontrados não apenas em Menino de engenho, mas em todos os romances que compõem o "Ciclo da cana-de-açúcar" (CASTELLO, 1961). De acordo com Candido \& Castello, fazem parte desse ciclo os romances Menino de engenho (1932); Doidinho (1933); Banguê (1934), Usina (1936) e Fogo morto (1943). Alguns autores - como Bosi e o próprio Castello - incluem no ciclo também a obra $O$ Moleque Ricardo (1935).
} 
que é iniciado no conhecimento mais aprofundado da literatura correspondente" (p. 89):

as experiências da infância e da adolescência, os estudos no Recife e os contatos com Gilberto Freyre e seu grupo, além dos reencontros posteriores com a região de origem, são os fatores decisivos na formação do romancista e explicam, em termos de memória e regionalismo, a obra que escreveu (CASTELLO, 1961, p. 95).

Em análise referente a Menino de engenho e aos romances que integram o "ciclo da cana-de-açúcar", Castello enaltece a influência de Freyre:

Com Menino de engenho, perfeitamente dentro da orientação de Gilberto Freyre, José Lins do Rego lançava os fundamentos de outros romances que formariam o que o próprio autor denominou "Ciclo da Cana-de-Açúcar" (CASTELLO, 1961, p. 92).

Desse modo, antes de evoluirmos nosso estudo para a análise da infância representada em Menino de engenho, vale a pena explorar um pouco mais essa amizade que viria a influenciar mutuamente os dois escritores, e avaliar como Gilberto Freyre nos apresenta esse "menino" do ponto de vista sociológico, antes de o encontrarmos representado e imortalizado na literatura de José Lins. 


\subsection{Gilberto e José: um encontro de "meninos de engenho" em uma "tarde de Recife"}

Dez anos haviam passado após a Semana de 22, quando José Lins do Rego, nome até então ainda pouco conhecido dos grandes círculos literários do Sudeste, publicou seu primeiro romance, Menino de engenho (1932), em edição custeada pelo próprio autor, no Rio de Janeiro. A aclamada obra de estreia abriu as portas para uma profícua carreira, interrompida pela morte precoce do romancista. Porém a história do futuro escritor começara a delinear-se nove anos antes, mais precisamente em 1923, logo após a eclosão do movimento modernista em São Paulo, quando o autor paraibano, recém-formado pela Faculdade de Direito do Recife, conhece Gilberto Freyre ${ }^{156}$, e com ele inicia uma amizade que mudaria os cursos de sua vida, e perduraria até seus últimos dias.

Abre-se aqui um breve parêntese para situar as infâncias desses dois jovens promissores talentos que despontavam como importantes personagens do cenário brasileiro nordestino do século XX.

José Lins do Rego nasceu no município de Pilar, na Paraíba, em junho de 1901. Gilberto Freyre nascera em Recife, em março do ano anterior. Os meninos seguiram rumos bem diferentes: enquanto o primeiro, com a morte da mãe, foi criado no Engenho do Corredor, propriedade do avô materno, o Coronel José Lins Cavalcanti de Albuquerque, o segundo crescia na capital pernambucana. Esse fato, porém, não evitou que Gilberto Freyre, ainda criança, também tivesse vivenciado "experiências rurais como menino de engenho". 0 episódio aconteceu em 1908, após a morte da avó, quando, então com sete para oito anos de idade, Gilberto foi levado com seus irmãos a passar uma temporada no Engenho São Severino do Ramo, propriedade dos Souza Mello, parentes da família ${ }^{157}$. No curto relato, semelhanças com a prosa de José Lins do Rego em Menino de engenho, Banguê e Meus verdes Anos podem ser aferidas em algumas citações, como o cultivo da cana, as cantigas entoadas pelos "negros velhos", histórias de "almas de outro mundo" e lobisomens, remédios caseiros, banhos de rio, os longos

\footnotetext{
156 Gilberto Freyre (1900-1987).

1570 episódio é relatado pelo próprio autor no capítulo "Santos e quase santos", de Pessoas, coisas \& animais (1979), volume de ensaios e artigos reunidos.
} 
passeios pelo engenho, entre outras (FREYRE, 1979, p. 11-13). De acordo com o próprio Freyre,

em São Severino do Ramo nossa meninice se familiarizou com a vida de engenho. Vimos fazer mel e açúcar, tudo explicado aos nossos olhos arregalados pelos primos velhos; bebemos garapa; e os banhos de rio nos pareceram melhores que os de Caxangá (FREYRE, 1979, p. 11).

No entanto, apesar dessas vivências como "menino de engenho"158, as infâncias de José Lins do Rego e Gilberto Freyre seguiram caminhos diversos: enquanto o primeiro permanece no engenho do avô, sem demonstrar o menor interesse pelas letras e pelos estudos, até os doze anos de idade, quando é então encaminhado para o Internato de Itabaiana, o segundo destaca-se como estudante no Colégio Americano Gilreath ${ }^{159}$, em Recife. Com catorze anos, Freyre "toma parte ativa nos trabalhos da sociedade literária da Instituição" e "torna-se redator-chefe do jornal impresso do colégio, O lábaro"160. Partindo para os Estados Unidos a fim de completar seus estudos, e, depois, para a Europa, volta ao Brasil somente em 1923, ano em que conheceria o romancista paraibano.

Nessa época, o jovem estudante José Lins do Rego vinha sendo influenciado literariamente pela amizade com o conterrâneo José Américo de Almeida ${ }^{161}$, e a vocação para as letras tornava-se emergente no aspirante a bacharel. Antes mesmo de concluir a Faculdade de Direito, o futuro romancista já era responsável por uma seção literária intitulada "Ligeiros traços" no Diário do Estado da Paraíba, além de ter fundado, juntamente com Osório Borba ${ }^{162}$, o periódico panfletário Dom Casmurro. Também

\footnotetext{
158 Poderia ainda citar como semelhança entre os meninos certa dificuldade com o aprendizado formal, apresentado por ambos, e a perda de uma pessoa querida - no caso de Gilberto Freyre, a avó; no caso de José Lins, a mãe, assassinada pelo pai, e a prima Lili, que morreu ainda criança.

${ }^{159}$ Fundado em 1906 por um missionário americano, hoje recebe o nome de Colégio Americano Batista.

${ }^{160}$ De acordo com a biobibliografia do autor (FONSECA, E. N. "Biobibliografia" in FREYRE, G. De menino a homem: de mais de trinta e de quarenta, de sessenta e mais anos. São Paulo, Global, 2010, p. 191-193).

161 José Américo de Almeida (1887-1980), romancista, poeta, ensaísta, crítico literário, autor de $A$ bagaceira (1928), romance considerado como inaugural do movimento regionalista moderno.

162 José Osório Borba (1900-1960), jornalista, político e escritor.
} 
escrevia crônicas semanais no Jornal do Recife (CASTELLO, 1961, p. 85-87). Mas é no encontro e na amizade com Gilberto Freyre que, segundo o próprio José Lins, estabelecese uma importante mudança nos rumos de sua vida.

Em uma entrevista, o romancista descreve como foi seu primeiro contato com o sociólogo, em uma "tarde de Recife":

Gilberto descia a Rua Nova. Eu já o conhecia de vista. Disse-lhe apenas: "Chamo-me José Lins do Rego". E apertei-lhe a mão. Desde então ficamos amigos ${ }^{163}$.

Em outro depoimento, publicado no prefácio que compôs para Região $e$ Tradição (1941), obra de Freyre, o escritor paraibano reitera a importância do amigo e a determinante influência que exerceu para sua "existência literária":

Conheci Gilberto Freyre em 1923. Foi numa tarde de Recife, do nosso querido Recife, que nos encontramos, e de lá para cá, a minha vida foi outra, foram outras as minhas preocupações, outros os meus planos, as minhas leituras, os meus entusiasmos. Pode parecer um romance, mas foi tudo realidade. [...] Para mim tivera começo naquela tarde de nosso encontro a minha existência literária. 0 que eu havia lido até aquele dia? Quase nada. Talvez que nem um livro sério do princípio até o fim. [...] Mas escrevia, por instinto, crônicas e contos. [...] Gilberto Freyre pediume para ler os meus retalhos de jornal. Leu as crônicas, os contos, e criticou-os, falando-me de alguns com interesse. Havia nos meus modos de dizer qualquer coisa que o interessou. $\mathrm{E}$ a minha aprendizagem com o mestre da minha idade se iniciava sem que eu sentisse as lições (REGO, 1941 apud CASTELLO, 1961, p. 89).

163 Declaração de José Lins do Rego em entrevista a Francisco de Assis Barbosa (TRIGO, 2002, p. 51). 
Já para Gilberto Freyre, a amizade com José Lins do Rego tornou-se "um complexo fraternalmente simbiótico" desde o seu princípio, prolongando-se durante mais de trinta anos. Em um de seus ensaios sobre o autor paraibano, o sociólogo relembra a época em que o conheceu e confidencia:

Os dois - José Lins e eu - nos completamos em várias das atividades que desenvolvemos e em diversas das tendências que desde 1923 - o ano em que começou nossa amizade - exprimimos com maior ou menor gosto ou ênfase, conforme o temperamento de cada um. [...] Completamo-nos através das influências que eu recebi dele e das que ele recebeu de mim. Sua vida e a minha tornaram-se, desde que nos conhecemos, duas vidas difíceis de ser consideradas à parte uma da outra, um complexo fraternamente simbiótico, de tal modo se interpenetraram, sem sacrifício do temperamento de um ao do outro (FREYRE, 1991, p. 95-96).

Três dias após a morte do amigo, Freyre publicaria no Diário de Pernambuco um texto bastante sentimental, em que revela toda a dor pela perda do companheiro, "o escritor brasileiro de sua época que mais intensamente admirou", e declara a grande cumplicidade que havia entre eles. Diz o texto:

A notícia da morte de José Lins do Rego chega-me aos ouvidos como o mais brutal dos absurdos. Nunca me pareceu que ele pudesse ser senão vida. Transbordamento de vida. [...] Sua vida transbordou de tal maneira na minha que desde que o conheci deixei de ser um só para ser quase dois. Nunca ninguém foi mais meu amigo. Nunca ninguém, sendo do meu sexo, mas não do meu sangue, me deu mais compreensão e mais afeto. [...] Sempre que nos reuníamos sua voz era uma festa para mim. Sua voz, sua palavra, suas risadas, seus gestos - tudo nele era festa para mim. [...] era uma presença que me completava. [...] Devo-lhe muito. Devo-lhe tanto que, sabendo-o morto, sinto-me como que ferido de morte. E com certeza, incompleto. Com ele morto, sou um vivo incompleto (FREYRE, 2010, p. 159-161) ${ }^{164}$.

164 Trecho de texto publicado no Diário de Pernambuco, em 15 de setembro de 1957. 
De acordo com entrevistas, ensaios e cartas, a afinidade que se estabeleceu entre os dois, logo após o primeiro contato, foi imediata. Embora tivessem até ali percorrido caminhos bastante distintos, incluindo a formação de Freyre no exterior ${ }^{165}$, aquele encontro em Recife permitiu que uma sólida amizade começasse a se desenvolver e influências mútuas fossem se revelando por meio de suas cartas e de suas obras. Eram "meninos de engenho" que se encontravam depois de crescidos, e se descobriam em um momento político e cultural favorável entre os círculos intelectuais nordestinos, especialmente na Paraíba, em Pernambuco e em Alagoas (CHAGURI, 2009, p. 35), estados onde se engendrava a renovação cultural da região Nordeste166.

A amizade entre o romancista e o sociólogo e a correlação entre suas obras foram tema de pesquisa de Cauby Dantas ${ }^{167}$, professor da Universidade Federal da Paraíba, que, para complementar seu trabalho, estudou - além de obras selecionadas as cartas trocadas entre eles durante mais de trinta anos. Em seu livro, Gilberto Freyre $e$ José Lins do Rego: diálogos do senhor da casa-grande com o menino de engenho, o pesquisador revela mais sobre o encontro dos "dois jovens aspirantes à condição de escritor", que ocorreu em momento de "efervescência cultural", no "entrechoque de dois projetos de renovação intelectual do país - o 'modernismo' paulista e o 'regionalismo' nordestino":

Os dois jovens aspirantes à condição de escritor se conheceram nesse contexto de efervescência cultural. Gilberto Freyre confessa [...] o seu débito para com José Lins do Rego, por lhe haver apresentado a vários dos autores "novos", citando, entre outros, Mário e Osvaldo de Andrade e Alceu Amoroso Lima. Nesse mesmo período, José Lins do Rego

\footnotetext{
165 Após concluir o curso do Colégio Americano Gilreath, Gilberto Freyre segue para os Estados Unidos, onde cursa o bacharelado em Artes na Universidade de Baylor e de Ciências Públicas, na Universidade de Colúmbia, onde também cursa o mestrado e defende tese intitulada Social life in Brazil in the middle of 19th Century (1922). Finalizados os cursos, parte para a Europa, conhecendo França, Alemanha, Bélgica e Inglaterra, antes de se fixar em Portugal. Volta ao Brasil somente em 1923. (FONSECA, E.N. "Biobibliografia" (FREYRE, 2010, p. 191-193).

166 "O regionalismo ganharia contornos claros a partir de 1924 com a fundação do Centro Regionalista do Nordeste e em 1926 com a realização do Primeiro congresso regionalista do Nordeste" (CHAGURI, 2009, p. 35).

167 De acordo com o autor, “Gilberto Freyre e José Lins do Rego mantiveram uma intensa e prolixa correspondência, iniciada em 1924, e que se estendeu praticamente até a morte do romancista, em 1957. São, no total, 238 cartas. Destas, 116 foram escritas por Gilberto Freyre, enquanto que José Lins do Rego mandou-lhe 122". Essas cartas são "parte do acervo do Museu José Lins do Rego da Fundação Espaço Cultural da Paraíba (FUNESC)" e contêm "valiosas informações, indo da política à reiteração da velha amizade; pesquisas e livros em andamento; muitos comentários sobre livros e autores; assuntos íntimos, relacionados a filhos e esposas; mudanças; questões financeiras" (DANTAS, 2015, p. 23).
} 
aprendia inglês, com Gilberto Freyre. Estava iniciado o diálogo intelectual que o passar dos anos apenas aprofundaria. Definitivamente inscrito na memória de ambos, esse primeiro encontro será posto em relevo em cartas íntimas e em artigos para jornais. Mais tarde, já consagrados, lembrarão aquele alvorecer em seus significados afetivos, existenciais e intelectuais (DANTAS, 2015, p. 18-19).

Segundo Dantas, "nem só por leituras é marcado o início do diálogo" entre José Lins do Rego e Gilberto Freyre. Assim como Castello, o pesquisador paraibano também cita os passeios e viagens como determinantes para a consolidação de um relacionamento que perduraria por muitos anos, e como fonte de inspiração para ambos:

a amizade será consolidada, também, nos passeios que fazem juntos, nas visitas a museus, a rios, a escombros de casas-grandes que lhes sugerem um vasto campo de observação que se revelará bastante profícuo na elaboração futura de ensaios e romances. Numa dessas viagens, à Paraíba, em 1924, José Lis do Rego apresenta ao amigo os engenhos do seu avô, José Lins Cavalcanti de Albuquerque [...](DANTAS, 2015, p. 55).

O próprio romancista revela, anos depois, em carta a Gilberto no fim de 1924, a importância da viagem à Paraíba e o apreço que cultivava pelo amigo:

Quase que não respondo a sua carta. Vivi dela uma porção de dias. Você, meu querido Gilberto, tem feito de mim gente. Por você eu teria a grande vitória sobre eu próprio. Fugi de muitas das minhas afinidades, curei-me de vários vícios. A minha melhor recordação, de mais intensa saudade, é daquela nossa primeira viagem à Paraíba. Nunca vivi dias mais inteligentes $[\ldots]^{168}$.

168 Carta de José Lins do Rego a Gilberto Freyre (1924) transcrita por Freyre no ensaio "Recordando José Lins do Rego" (COUTINHO \& CASTRO, 1991, p. 101). 
Nos anos que se seguem, e em que os amigos se separam fisicamente, o apreço mútuo continua por meio das cartas. De acordo com Dantas, essa correspondência "atravessa um período de 32 anos, sendo a primeira carta [...] datada de 17 de janeiro de 1925, e a última, de 14 de dezembro de 1956, ambas escritas por Gilberto" (DANTAS, 2015, p. 94). É por meio dessas cartas e também de obras pontuais dos dois autores que o pesquisador tenta alcançar os objetivos de sua pesquisa, entre os quais, "indagar quanto à presença, na obra de José Lins do Rego, das variáveis fundamentais atribuídas por Gilberto Freyre à sociedade tradicional brasileira: o patriarcalismo, o latifúndio, [...] a monocultura e o regime escravocrata", e investigar as "coincidências" expressas "no tratamento conferido a conceitos como região, decadência, triângulo rural (casaengenho-capela), entre outros" (p. 20).

Não caberá a nós tarefa semelhante, uma vez que nosso propósito é o de analisar a infância representada literariamente na obra de estreia do romancista. No entanto, por se tratar de Menino de engenho, e em vista da declarada influência mútua entre o romancista e o sociólogo, torna-se interessante percebermos como essa infância "não-literária" foi descrita pelo segundo, sobretudo com relação aos "meninos de engenho", e para isso nos valeremos de algumas passagens de duas de suas mais significativas obras: Casa-grande e senzala (1933) e Sobrados e mucambos (1936), publicadas na mesma época em que José Lins lançava seus primeiros romances.

0 período abordado por Freyre em ambas as obras precede aquele que limitamos como recorte para esta pesquisa - as primeiras décadas do século XX -, porém muitas das características que ele retrata em seus estudos acerca das constituições familiares e do tratamento dispensado à criança ainda configuraram heranças remanescentes de uma sociedade patriarcal e escravocrata, encontradas no início do século passado, especialmente no que se refere à sociedade rural nordestina.

Assim, em Sobrados e mucambos, no capítulo destinado a analisar a relação entre pais e filhos em uma sociedade patriarcal ${ }^{169}$, Gilberto Freyre discorre sobre a diferença entre homens e meninos, ou entre adultos e "párvulos" (para manter a expressão portuguesa, como o autor a utilizou), que, segundo ele, era "tão grande como a que separa os sexos [...]; tão grande como a que separa as classes" (FREYRE, 1996, p.

${ }^{169}$ FREYRE, G. “O pai e o filho” IN: Sobrados e Mucambos. 9. ed., Rio de Janeiro, Record, 1996, p. 67-92. 
67). De acordo com o autor, tamanho era o prestígio do "homem feito", nas sociedades patriarcais,

\begin{abstract}
que o menino, com vergonha da meninice, deixa-se amadurecer, morbidamente, antes do tempo. Sente gosto na precocidade que o liberta da grande vergonha de ser menino. Da inferioridade de ser párvulo. Tamanho é o prestígio da idade grande, avançada, provecta, naquelas sociedades, que o rapaz imita o velho desde a adolescência. E trata de esconder por trás de barbas de mouro, de óculos de velho, ou simplesmente, de uma fisionomia sempre severa, todo o brilho da mocidade, toda a alegria da adolescência, todo o resto de meninice que lhe fique dançando nos olhos ou animando-lhe os gestos (FREYRE, 1996, p. 67).
\end{abstract}

Ainda, de acordo com Freyre, há uma grande distância entre a primeira infância, marcada pelos primeiros seis ou sete anos de vida, quando a criança era identificada como um verdadeiro "anjo", e os anos vindouros, os anos de "meninodiabo", "criatura estranha, cheia do instinto de todos os pecados, com a tendência para a preguiça e a malícia" (FREYRE, 1996, p. 68):

É verdade que a meninice, nas sociedades patriarcais, é curta. Quebramse logo as asas do anjo. E desse modo se atenua o antagonismo entre $o$ menino e o homem, entre o pai e o filho. [...] (FREYRE, 1996, p. 67).

O sociólogo acrescenta à sua análise sobre essa sociedade o domínio do pai na "administração da justiça e família”, o que lhe concedia o direito de castigar e até matar ou mandar matar, "não só os negros como os meninos e as moças brancas, seus filhos" (FREYRE, 1996, p. 69). Assim, falando sobre o "menino", ele afirma que

[...] seu corpo era o mais castigado dentro de casa. Depois do corpo do escravo, naturalmente. Depois do corpo do moleque leva-pancada, que às vezes apanhava por ele e pelo menino branco. Mas o menino branco também apanhava. Era castigado pelo pai, pela mãe, pelo avô, pela avó, 
pelo padrinho, pela madrinha, pelo tio-padre, pela tia solteirona, pelo padre-mestre, pelo mestre-régio, pelo professor de Gramática. Castigado por uma sociedade de adultos em que o domínio sobre o escravo desenvolvia, junto com as responsabilidades de mando absoluto, o gosto de judiar também com o menino (FREYRE, 1996, p. 68-69).

Essa "autoridade" em nome de um "interesse real ou ostensivo da educação, ou da moralização do menino", de acordo com Freyre, tomou muitas vezes um caráter "sádico", que passou da família para os colégios, uma vez que os "pais autorizavam mestres e padres a exercerem sobre os meninos o poder patriarcal de castigá-los a vara de marmelo e a palmatória" (p. 70). Para o autor,

através de processo tão cru de ensinar ao aluno o latim, a gramática, a doutrina, as boas maneiras, conservou-se enorme a distância social entre o homem e o menino. Nos colégios de padre, aprimorou-se o princípio de ser a meninice, dos seis aos dez ou aos doze anos, idade teologicamente imunda, durante a qual o indivíduo, sem as virtudes do adulto, adquiridas a custo, apenas se fazia tolerar [...]. Essa distância, quando não conservada pelo próprio menino, lhe era imposta por todos os jeitos, mesmo os mais cruéis (FREYRE, 1996, p. 70-71).

Já em Casa-grande \& senzala (1933), Gilberto Freyre propõe mais que uma análise da sociedade brasileira desde o período de colonização, considerando a contribuição dos diferentes povos que participaram da sua formação, mas uma minuciosa descrição da estrutura familiar vigente nessa época, pautada no regime patriarcal. Nesse contexto, o autor analisa desde as práticas e os cuidados para com a criança indígena como a rotina dos meninos e moleques dos engenhos.

Sobre a criança indígena, Freyre revela a forma como era tratada, destacando tanto os costumes com relação ao asseio e à higiene como as superstições que a rodeavam, desde o seu nascimento, fosse para afastar "espíritos ou influências 
malignas", fosse para sujeitá-la à autoridade "dos grandes"170. Descreve ainda as danças e brincadeiras e os rituais de iniciação a que os curumins eram submetidos ao chegar à puberdade. Para a criança branca e para a criança negra, o autor dedica mais espaço, quando retrata os "meninos de engenho" e os moleques, crias da casa, referindo-se, neste caso, a crianças escravas ou filhas de escravas, consideradas "agregadas" da família.

As causas da alta mortalidade infantil da época também são abordadas pelo autor: problemas com o "mau tratamento do cordão umbilical, vestuário impróprio, [...], alimentação desproporcional, insuficiente ou imprópria, desprezo no princípio das moléstias da primeira infância [...], desproporção na idade dos cônjuges; [...] aleitamento por escravas nem sempre em condições higiênicas de criar" (FREYRE, 2005, p. 450), entre outras. Freyre atribui a essa alta taxa de mortalidade infantil o conformismo e até "certa felicidade" com a morte de uma criança, que se transformaria, segundo as crenças, em "anjos do céu" (p. 450). Segundo o autor,

perder um filho pequeno nunca foi para a família patriarcal a mesma dor profunda que para uma família de hoje. Viria outro. 0 anjo ia para o céu. Para junto de Nosso Senhor, insaciável em cercar-se de anjos (FREYRE, 2005, p. 450).

Outra característica da época descrita pelo sociólogo era o sadismo com que uma criança tratava outras e também era tratada, especialmente no caso de meninos brancos, filhos dos senhores, maltratando as "crias da casa". 0 autor credita aos castigos recebidos pela própria criança essa dose de crueldade em suas brincadeiras futuras, que faziam jus à alcunha de "menino-diabo", tão bem citada por Machado de Assis, em Brás Cubas $^{171}$. Para Freyre,

\footnotetext{
${ }^{170}$ FREYRE, G. "O indígena na formação da família brasileira” IN: Casa-grande \& senzala, 50ª ed. São Paulo, Global, 2005, p. 156-232.

${ }^{171}$ Conforme já comentado no Capítulo 1 desta tese (ver páginas 42-43).
} 
o menino do tempo da escravidão parece que descontava os sofrimentos da primeira infância - doenças, castigos por mijar na cama, purgante uma vez por mês - tornando-se dos cinco aos dez anos verdadeiro menino-diabo. Seus jogos e brincadeiras acusam nele [...] tendências acremente sadistas. E não era só o menino de engenho, que em geral brincava de bolar carro, de matar passarinho e de judiar com moleque: também o das cidades [...] (FREYRE, 2005, p. 451-452).

O autor também relata as contradições com que o menino era criado: às vezes cercado de mimos exagerados; às vezes solto em demasia, sem que houvesse controle por parte do adulto sobre a sua liberdade. Para ele,

era essa atitude dos pais, tolerando nos filhos a estupidez e a malvadeza e até estimulando-os a bravatas, que o padre Lopes Gama ${ }^{172}$ não compreendia nem perdoava. Não compreendia que deixassem os meninos de família viver pelos telhados como gatos e pelas ruas empinando papagaio; jogando a pedrada e o pião "com a rapaziada mais porca e brejeiral [...]" (FREYRE, 2005, p. 451-452).

Acrescenta ainda nas citações do "padre-mestre" o comportamento dos "filhos dos senhores de engenho", que, em vez de aprenderem a ler e escrever, praticavam "desumanidades" com os filhos de escravos e se divertiam com brincadeiras infames, como perseguir aves, matá-las e destruir ninhos, além de adquirir "linguagem viciosa" e o maléfico hábito de comer terra (p. 453-455).

Outro aspecto destacado pelo sociólogo é a precocidade sexual do menino, atribuída em grande parte pela convivência com os moleques (escravos ou filhos de escravos) e com as escravas, que muitas vezes eram as responsáveis por iniciá-los na vida sexual. Em suas palavras,

172 Padre Lopes Gama (1791-1852), jornalista, político e fundador e redator do jornal O Carapuceiro (1832-1847). 
em outros vícios escorregava a meninice dos filhos do senhor de engenho; nos quais um tanto por efeito do clima e muito em consequência das condições de vida criadas pelo sistema escravocrata, antecipou-se sempre a atividade sexual, através de práticas sadistas e bestiais. As primeiras vítimas eram os moleques e animais domésticos; mais tarde é que vinha o grande atoleiro da carne: a negra ou a mulata. Nele é que se perdeu, como em areia gulosa, muita adolescência insaciável [...] (FREYRE, 2005, p. 451-452).

\section{Em outro trecho o autor complementa:}

Nenhuma casa-grande do tempo da escravidão quis para si a glória de conservar filhos maricas ou donzelões. 0 folclore da nossa antiga zona de engenhos de cana e de fazendas de café quando se refere a rapaz donzelo é sempre em tom de debique: para levar o maricas ao ridículo. 0 que sempre se apreciou foi o menino que cedo estivesse metido com raparigas. Raparigueiro, como ainda hoje se diz. Femeeiro. Deflorador de mocinhas. E que não tardasse em emprenhar negras, aumentando o rebanho e o capital paternos (FREYRE, 2005, p. 456).

Em suma, Freyre considera a precoce iniciação sexual do menino brasileiro como um dos "vícios de educação" decorrentes desse sistema escravocrata e da falta de constância na sua criação - ora com excesso de mimos, ora com liberdade desenfreada que lhe era concedida. Acrescenta ainda o destempero dos pais ou parentes mais velhos, abreviando a infância dos meninos e apresentando-lhes logo a vida adulta, entregandolhes facas de ponta e incentivando-os nos prazeres do sexo. Para o autor,

tanto o excesso de mimo de mulher na criação dos meninos e até dos mulatinhos, como o extremo oposto - a liberdade para os meninos brancos cedo vadiarem com os moleques safados na bagaceira, deflorarem negrinhas, emprenharem escravas, abusarem de animais constituíram vícios de educação, talvez inseparáveis do regime de economia escravocrata, dentro do qual se formou o Brasil. Vícios de educação que explicam melhor do que o clima, e incomparavelmente melhor que os duvidosos efeitos da miscigenação sobre o sistema do mestiço, a precoce iniciação do menino brasileiro na vida erótica [...]. 
Imagine-se um país com meninos armados de faca de ponta! Pois foi assim o Brasil do tempo da escravidão. [...] A verdade, porém, é que o hábito da faca de ponta deve datar dos primeiros tempos da colonização, quando meninos e gente grande deviam estar sempre prontos a enfrentar surpresas de índios e de animais selvagens. Daí, em grande parte, certa precocidade nas crianças coloniais, cedo chamadas a participar das angústias e preocupações dos adultos. E também dos prazeres ou gozos, que eram principalmente os do sexo" (FREYRE, 2005, p. 459-462).

É interessante notar como várias dessas citações de Gilberto Freyre extraídas de Casa-grande \& senzala sobre a infância "do menino" na sociedade patriarcal casamse harmoniosamente com o texto literário de José Lins do Rego, especialmente em Menino de engenho. Embora Casa-grande \& senzala tenha sido publicado após o romance de estreia de José Lins, o próprio romancista confessa ao amigo ter usado seus estudos sociológicos como fonte de "inspiração" para compor seu primeiro romance. De acordo com Freyre, em 1933 José Lins escreveu-lhe do Rio de Janeiro a respeito da publicação do livro,

do qual já me lera trechos durante uma manhã inteira, dizendo-o inspirado em meu projeto de uma reconstituição da vida de menino no Brasil - nos engenhos e nas cidades. Projeto já esboçado por mim em certos trechos de Vida social no Nordeste (publicado em 1925) (FREYRE, 2005, p. 459-462).

Desse modo, na obra de José Lins, vamos pouco a pouco sendo apresentados literariamente ao senhor do engenho, aos trabalhadores do eito, às mulatas, aos moleques da bagaceira, aos meninos, aos "vícios de educação", todo esse universo rural e herdeiro de uma sociedade escravocrata, representado na ficção. 
Para Cauby Dantas, em Menino de engenho o romancista dedica-se a introduzir o leitor no universo do Engenho Santa Rosa, "flagrado em sua dimensão cotidiana", revelando "a forte presença [...] da visão freyriana, inscrita nos textos da década 1920, acerca do pretenso caráter ameno, de antagonismos equilibrados, da escravidão nos engenhos de açúcar" (DANTAS, 2015, p. 128). Para o pesquisador,

o leitor é gradativamente apresentado aos seus habitantes, aos seus costumes, suas festas, sua fauna e sua flora, suas relações de trabalho, e a sua economia, pautadas na plantação de cana para a fabricação de açúcar. Estamos em um universo rural, agrário, com claros resquícios dos tempos da escravidão, presentes não apenas nos restos da antiga senzala - chamada pelos negros de "rua" - mas personificados nos vários descendentes do antigo regime (DANTAS, 2015, p. 127).

De acordo com Dantas, "com a abolição de 1888 e sem muitas alternativas, muitos dos ex-escravos continuaram morando na casa-grande, gravitando em torno de sua cozinha ou prestando pequenos serviços em troca de um prato de comida, como agregados [...]." (DANTAS, 2015, p. 128). Em sua prosa, José Lins revela literariamente todos os aspectos sociológicos da vida no engenho e da sua hierarquia, mostrando o papel de cada um dentro desse sistema:

além dos ex-escravos, aparecem os trabalhadores do eito que, de sol a sol, em jornadas que chegam a mais de doze horas por dia, limpando os partidos e plantando e colhendo os produtos agrícolas - a cana, o algodão e, também, o gado - que fazem a riqueza material do engenho. [...] 0 quadro é completado pela aparição, aqui e ali, de vários meninos, os "moleques da bagaceira", ocupados em tarefas de menor significado como banhar os cavalos, conduzir o gado aos currais, levar e trazer recados, etc. Acima de todos situa-se o coronel José Paulino, o patriarca e proprietário de nove engenhos. Elemento ativo, de sua vontade e ação, dependem a vida e a morte dos habitantes do Santa Rosa (DANTAS, 2015, p. 128). 
Desse modo, passemos à análise de Menino de engenho e do contexto sociocultural em que foi publicado, e assim, poderemos nos aprofundar em todos os aspectos aqui citados, encontrando as pontas que um dia uniram "numa tarde de Recife" vida e obra de José Lins e Gilberto Freyre.

\subsection{Uma literatura "cheirando a canavial e melaço da terra"}

Em uma crônica sobre José Lins do Rego, publicada em 1936 com o título “Ciclo da cana-de-açúcar”, o poeta Manuel Bandeira (1886-1968) menciona o espanto com que recebeu e conheceu o romancista, "primeiro exemplo de pura prosa brasileira, cheirando a canavial e melaço da terra do Nordeste" (BANDEIRA, 1991, p. 310).

Que surpresa esse José Lins do Rego! Já tinha mais de vinte e cinco anos quando apareceu pela primeira vez no Rio, falando feito cabra de engenho, gaguejando muito, sempre com ar aperreado, e escrevendo esporadicamente umas notas críticas meio bambas e meio erradas. Eu não tinha fé no matuto. Nunca que ninguém tivesse fé, a não ser, talvez, o mestre do Karrapicho, o modesto sociólogo de Casa-grande e senzala (BANDEIRA, 1991, p. 310).

Em análise dos cinco primeiros romances do escritor paraibano, o poeta revela toda a sua admiração pelo romancista, cobrindo-o de elogios. Para Bandeira, os romances que formam o chamado "ciclo da cana-de-açúcar" revelam uma 
prosa de uma naturalidade, de uma espontaneidade, de uma força que fazem esquecer tudo o que carregam de imperfeições, de desmazelo, de incúria estilística. Porque o estilo de José Lins do Rego é um estilo de cheia de rio - barrento, libidinoso, arrastando tudo que encontra na cabeça de água; troços de mocambo, porteiras de engenho, árvores derrubadas, gado afogado, o diabo. Não tenho a menor dúvida em afirmar que aqui, nestes cinco livros do romancista paraibano, está o ponto de partida da verdadeira prosa brasileira (BANDEIRA, 1991, p. 310 ).

No final da crônica, faz uma interessante contraposição entre o homem José Lins do Rego e o menino que habita em sua memória. Para ele, o romancista compõe sua obra com simplicidade e sem pretensões, "com aquele ar de quem está fazendo apenas uma crônica de família, de quem está tão-somente desafiando lembranças da meninice" (BANDEIRA, 1991, p. 311). E complementa:

O menino José Lins do Rego é quem explica o milagre de emoção que são estes cinco volumes. 0 homem foi quem escreveu a vida, paixão e morte dos banguês, mas quem sentiu tudo isso foi o menino de engenho que fazia safadezas nas casas-grandes dos engenhos da Paraíba. E que sorte tivemos que este menino possuísse tão rara sensibilidade e a rara memória dessa sensibilidade! (BANDEIRA, 1991, p. 311).

Vinte e dois anos depois, em julho de 1958, no discurso de posse de Afonso Arinos na Academia Brasileira de Letras, que sucedeu a José Lins após sua morte, Bandeira lembra não só o consagrado romancista, mas o narrador em potencial que era o escritor paraibano. Em suas palavras,

os romances de José Lins encantavam-me duas vezes: quando eu os lia e antes, quando, na fase em que ele os estava escrevendo, me ia narrando os sucessivos episódios. 0 romancista falava, então, não como se me estivesse expondo a sua ficção, mas como se falasse de 
personagens reais de carne e osso. Era uma delícia. E a obra sempre lhe saía da pena com aquele calor humano que fazia esquecer certas falhas do escritor, avesso ao trabalho de reler e emendar [...]. O homem Lins do Rego valia o romancista. Os seus defeitos eram todos defeitos nascidos da generosidade ${ }^{173}$.

Também Carlos Drummond de Andrade (1902-1987), em nota à 80ª edição de Menino de engenho, não poupa elogios ao romance e a seu criador. Para o poeta, “os romances mais autênticos de José Lins, os de sua infância dramatizada, dos quais Fogo morto é como um epílogo magistral, continuam doendo depois de lidos, porque a narrativa foi além da simples diversão aparente”. De acordo com suas palavras,

o romancista colocou largamente sua presença entre os acontecimentos, seja de forma direta, seja através de impressões e modos particulares de ver e sentir; ofereceu-se em confidencia, tocounos. [...] Coube a José Lins nascer e passar a infância num período de crise, isto é, de romance em potencial, em que uma forma de viver se despedia de toda uma região. 0 sentimento agudo do ficcionista captou os conflitos gerados por esse desmoronamento silencioso (a transformação não era revolucionária, mas por desgaste, e poderia mesmo passar despercebida), e construiu com eles alguns livros cuja sorte independe de revisões estéticas, porque são o encontro afortunado de uma situação, de uma experiência e de um dom de narrador. Se José Lins se debruçasse mais sobre si mesmo do que sobre as coisas, se fosse mais sutil ou requintado, como desejariam alguns, esse ajustamento espontâneo não seria talvez possível, e nossa literatura teria perdido um de seus monumentos (ANDRADE, 2001, $\mathrm{s} / \mathrm{p})$.

Rachel de Queiroz (1910-2003), autora que também despontou na década de 1930 na ficção nordestina, nos revela como a obra de estreia de José Lins do Rego foi recebida no cenário da literatura brasileira174:

\footnotetext{
173 Discurso de Manuel Bandeira IN: MONTELLO, J. “Culto da imortalidade: o romancista José Lins do Rego" - Conferência proferida na ABL, em 15.5.2001, encerrando o ciclo Centenário de José Lins do Rego (http://www.academia.org.br/abl/media/imortalidade15.pdf).

174 Ensaio publicado originalmente na 17ạ edição de Menino de engenho, de 1972, quando se comemoravam 40 anos da primeira edição do romance.
} 
Menino de engenho destacava-se especialmente importante naquela safra de 1931-1932 porque não era, como os livros de alguns de nós, obra primeira de menino precoce, marcada pelas falhas da estreia juvenil. [...] José Lins, na casa dos trinta, começava como romancista, mas era nome feito nas rodas intelectuais do Recife e até do Rio, autor de artigos, ensaios e estudos de crítica; já tinha bem afiada a sua ferramenta e completara a sua formação literária; e, com Menino de engenho, o romancista José Lins do Rego praticamente nos mostrava a sua face definitiva (QUEIROZ, 2013, p. 18).

A autora ainda atribui à espontaneidade de "Zé Lins" o seu "principal encanto, a sua força maior", e explica o modo como o "ciclo" se introduziu ao autor, acreditando que, "obedecendo às injunções da época", ele tenha simplesmente "consentido" que se "seriassem os seus primeiros romances num ciclo, segundo a moda". Para ela, José Lins

queria simplesmente fazer romances, desabafar o seu vulcão de memórias, de criações, de personagens e vivências. Coincidia que essas memórias, personagens e vivências eram as da sua meninice e mocidade, passadas na zona da cana-de-açúcar; e daí nasceu a ideia do ciclo da cana-de-açúcar, que praticamente lhe foi imposta pelos críticos. E ele se submeteu a aparente rotulagem, lisonjeado como fica todo artista criador quando atribuem um sistema, uma ideologia diretora, ao que ele sabe muito bem que é fruto nascido dentro dele, e não por ele fabricado (QUEIROZ, 2013, p. 19).

A autora declara ainda que Menino de engenho "era um marco, uma voz nova e clara a dar o seu recado como ainda não se dera" - e, ao mesmo tempo, uma "obra de arte da melhor" (QUEIROZ, 2013, p. 17).

De acordo com Alfredo Bosi, foi a partir de José Lins do Rego, com os romances do ciclo da cana-de-açúcar, que a região canavieira da Paraíba e de Pernambuco encontrou "a sua mais alta expressão literária" (BOSI, 1990, p. 446). Para o crítico, o romancista paraibano "soube fundir numa linguagem de forte e poética oralidade" as recordações da sua infância e da adolescência "com o registro intenso da vida nordestina colhida por dentro, através dos processos mentais de homens e mulheres que representam a gama étnica e social da região" (BOSI, 1990, p. 446-447). 
Bosi exalta ainda o fato de a "riqueza no plano do relacionamento com o real" refletir na composição de José Lins "maior força de estruturação literária”, constituindo marca indissociável do autor uma narrativa essencialmente memorialista. Para Bosi, embora tenha levado algum tempo para que o romancista "se desapegasse do material de base, feito de obsessões pessoais" e assim conseguisse "transcender aquela fusão de escritor e criança, escritor e adolescente, peculiar à sua obra inicial", seu fluxo narrativo e sua linguagem característica alinham-se aos "cantares de origem popular, que acumulam episódios, trechos descritivos e notações morais", equiparando-se ao substrato pertencente ao "reino imenso da memória" (BOSI, 1990, p. 448-449).

Também para Candido \& Castello, em toda a obra de José Lins "sente-se a presença do telúrico nostálgico da infância e da adolescência”, justificando-se, assim, o "caráter predominantemente memorialista" de sua ficção (CANDIDO \& CASTELLO, 1968, p. 251). Para os autores, por meio das narrativas, o autor evidencia os contrastes entre a exuberância da casa-grande e a "promiscuidade e a miséria das senzalas", revelando o declínio de uma era de tradições oriundas do século XVI (p. 251). Desse modo,

a visão dessa humanidade em ruína e dessa sociedade decadente, presa à experiência da infância e da adolescência do romancista, sofre a deformação determinada pelo orgulho íntimo que gera o processo do seu próprio reconhecimento, como se desse vida a fantasmas, que se fazem permanentemente presentes, ao mesmo tempo emoldurados pelos relatos orais (CANDIDO \& CASTELLO, 1968, p. 251).

Os autores ainda comparam o romancista a um "verdadeiro aedo popular, com o privilégio do poder de visão total", refletindo a "memória coletiva através dos seus processos narrativos" (CANDIDO \& CASTELLO, 1968, p. 251).

Para Castello, "toda a obra de ficção de José Lins do Rego exprime [...] o homem profundamente identificado com a sua terra, o seu povo, a sua região e por extensão o seu país e a humanidade" (CASTELLO, 1966, p. 24). De acordo com o crítico, “a parte de sua obra mais intimamente ligada à terra e à sua própria experiência individual é aquela constituída pelo ciclo da cana-de-açúcar", exprimindo a sua natureza "essencialmente telúrica e primitivista" (p. 23). Ainda para Castello, o regionalismo não atua em sua obra como algo meramente figurativo, dispensável ou superficial, mas "manifesta-se como a 
expressão lírica de um nordestino a evocar sua terra [...], de dentro para fora" (p. 94), revelando-se como "depoimento sentido, profundamente humano e lírico da própria natureza e das condições humanas sob contingências telúricas e sob os efeitos de transformações econômicas e sociais" (p. 94). Para o autor, porém, mais abrangente que o regionalismo em sua obra é a condução de sua narrativa para o "drama humano", matéria prima de seus romances. Assim,

tal compreensão mais uma vez justifica a atitude do memorialista - o segredo da criação de José Lins do Rego - corroborando aquela exigência interior de revelar o seu sentimento de simpatia e compreensão do pedaço de humanidade de que fez parte. E de tal forma que nunca se libertará de sua experiência dentro dos limites humanos e sociais da paisagem açucareira do Nordeste (CASTELLO, 1966, p. 9495).

Ainda nos dizeres de Castello, "todo romancista é um memorialista, no sentido em que o romance é a libertação de um estado interior profundo, soma de experiências observadas e vividas" (CASTELLO, 1966, p. 84). Desse modo, Menino de engenho tornase uma das obras de referência em que a fusão do memorialista e do romancista se fortalece para compor uma narrativa que, ao mesmo tempo que evoca as angústias e experiências vividas por um menino em sua tenra infância, revela o início da decadência da oligarquia dos senhores de engenho - refletida na figura de seu avô - como uma metáfora de uma série de transformações por que já passava a sociedade brasileira, no início do século XX.

No entanto, por mais que Menino de engenho apresente esse evidente cunho autobiográfico - declarado pelo próprio autor e já exaustivamente analisado e explorado por aqueles que se dedicaram a estudar sua obra -, não se pode deixar de ressaltar que, a partir do momento em que a "realidade" se traduz em ficção, passam a valer as regras que determinam o caráter ficcional do texto, isto é, a deformação natural por que passam os "fatos reais" pelo inexorável filtro da arte.

Para Antônio Carlos Villaça175 "há em Menino de engenho a vitória do romancista sobre o memorialista". Para o crítico, o livro

175 Antônio Carlos Villaça (1928-2005). Escritor, jornalista e memorialista. 
é uma evocação nostálgica, um depoimento veraz e espontâneo, incontrolado, uma catarse. E plenamente se aplica a José Lins do Rego o que ele escreveu a respeito de Jorge Lima, seu amigo - "O Nordeste não aparece ali como tema ou imposição doutrinária, mas se manifesta como a expressão lírica de um nordestino a evocar a sua terra. Não é uma atitude de fora para dentro, mas de dentro para fora." A fusão de regionalismo e universalidade dá ao romance de Lins do Rego a sua força impressionante e perene. Menino de engenho venceu o tempo. Ouçamos Valdemar Cavalcanti176: "Foi em Maceió, fins de 1931. Íamos andando pela rua, quando José Lins de repente me pegou pelo braço e confessou - vou escrever um livro, uma espécie de memória..." (VILLAÇA, 2001, s/p).

O fato de José Lins do Rego ter alterado o título original do livro - "Memórias de um menino de engenho" -, conforme é possível depreender do fac-símile do primeiro caderno em que o autor escrevia à mão seu romance (Figura 1), subtraindo justamente o termo "memórias", pode denotar uma proposital desvinculação entre escritor e personagem, dando a Carlinhos suas próprias pernas para que ele seguisse seu caminho, como um verdadeiro herói a desafiar suas feras e a enfrentar seu destino.

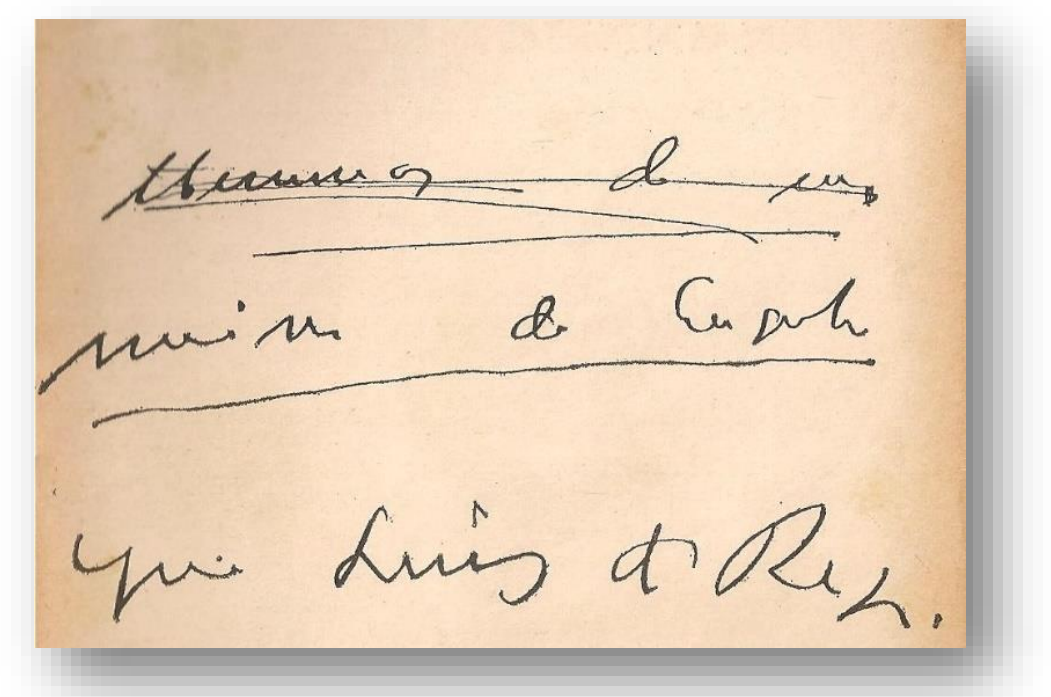

FIGURA 1 - Fac-símile (detalhe) da capa do primeiro dos três cadernos manuscritos de Menino de Engenho. 0 título original do romance: "Memórias de um menino de engenho", alterado pelo próprio autor (reproduzido em REGO, 1966).

\footnotetext{
176 "Valdemar Cavalcanti, no transcurso do quadragésimo aniversário da publicação do primeiro romance do Ciclo da Cana-de-Açúcar, publicou no Jornal do Brasil (28 de abril de 1972) uma crônica evocativa, que nos permite surpreender o Menino de engenho no instante de seu fiat genésico" in: MONTELLO, J. "O romancista José Lins do Rego". Conferência proferida na ABL, em 15.5.2001, encerrando o ciclo Centenário de José Lins do Rego, p. 14.
} 
Para Ivan Cavalcanti Proença177, em ensaio publicado na 105a edição do livro, há algo de lírico, dramático e mesmo épico na saga de Carlinhos. 0 autor considera Menino de engenho não apenas obra inaugural do romancista, mas "a mais significativa no ciclo da cana-de-açúcar e fora dele" (PROENÇA, 2013, p. 9). Para ele, o romance

\begin{abstract}
é tão lírico como dramático, e há nele ainda sinais de epicidade [...]. Ali, planejada ou não, aquela consciência crítica social resultante de literalidade maior - artesanato de escrita simples e profunda, a criação de personagens típicos e indivíduos, a força do meio sobre as gentes do engenho: o patético, o lírico e o pungente tensionados. [...] Zé Lins desenvolve a única, e trabalhada, narrativa possível, adequada e verossímil, àquela presença telúrica e sinestésica da cana-de-açúcar, das negras quentes e exuberantes, dos moleques amigos, do sexo, das angústias e, muito das sucessivas sensações de perda do menino (PROENÇA, 2013, p. 9-10).
\end{abstract}

E é buscando essas sensações de perda de um menino em seus mais amplos sentidos - a começar pela perda dos pais e a terminar pela "perda" do engenho e da liberdade inerente a essa época da sua vida - que tentaremos seguir os passos dessa "infância perdida" por meio da análise de Menino de Engenho.

177 Ivan Cavalcanti Proença, escritor e professor de literatura. 


\subsection{A infância de um "menino perdido"}

"Menino perdido, menino de engenho". Com essa frase, o narrador e protagonista de Menino de engenho encerra sua narrativa, despedindo-se melancolicamente tanto do leitor como da sua própria infância ${ }^{178}$. Porém, para se compreender o que levou o personagem Carlos de Melo (ou apenas Carlinhos) a essa autodenominação - "menino perdido" -, é necessário voltar ao início do enredo, quando ele era apenas um garotinho de aproximadamente quatro anos de idade e presencia um fato que mudaria para sempre sua história: a morte prematura da mãe, assassinada pelo próprio pai. É desta forma que a narrativa tem início:

Eu tinha uns quatro anos no dia em que minha mãe morreu. Dormia no meu quarto, quando pela manhã me acordei com um enorme barulho na casa toda. Eram gritos e gente correndo para todos os cantos. 0 quarto de dormir de meu pai estava cheio de pessoas que eu não conhecia. Corri para lá, e vi minha mãe estendida no chão e meu pai caído em cima dela como um louco. A gente toda que estava ali olhava para o quadro como se estivesse em um espetáculo (REGO, 2013, p. 25).

A falta de exatidão da sua idade ("uns quatro anos"), embora pudesse ser estimada com mais rigor, favorece a ideia de que tudo o que será contado está no plano das impressões, qualidade inerente à imprecisão da memória. Por outro lado, a narração em primeira pessoa promove um caráter de intimidade com o leitor, como se ele fosse conduzido para dentro daquela casa, e testemunhasse com seus próprios olhos a cena do crime, classificada pelo narrador como "quadro" e "espetáculo", vocábulos comumente associados ao contexto da arte e do teatro, tornando-nos também espectadores e, de certa forma, cúmplices da tragédia que se abateu sobre ele.

\footnotetext{
1780 personagem Carlos de Melo (Carlinhos, em Menino de engenho) voltaria a protagonizar ainda outros romances: Doidinho (1933) e Banguê (1934). Nesta tese, analisaremos apenas Menino de engenho, que narra a infância do personagem no período situado entre sua orfandade, aos quatro anos, até seu encaminhamento ao colégio interno, aos doze.
} 
Assim, desde o primeiro capítulo, é possível depreender a carga emocional com que o narrador reconstruirá o seu passado, trazendo à tona os momentos mais marcantes de sua vida, exacerbados pelo sentimento de perda que o acompanhará durante toda a sua infância e será resgatado por diversas vezes durante a narrativa.

A ausência prematura dos pais transforma para sempre a vida de Carlinhos, levando-o da cidade ao Santa Rosa, engenho do avô, onde a maior parte do enredo se desenvolverá, a partir do terceiro capítulo do livro. Logo na sua chegada, o menino é apresentado à sua nova realidade e às pessoas que farão parte dela: a tia Maria, que será para ele como uma "segunda mãe", a tia Sinhazinha, por quem o personagem tem aversão desde o princípio, como a uma "madrasta", o tio Juca e o avô, José Paulino, os primos que eventualmente aparecem, e os "moleques" e trabalhadores que vivem nos arredores. E é entre olhares enviesados, ora cheios de piedade, ora de desconfiança ${ }^{179}$, que se construirá nesse novo espaço - o engenho - a infância do menino. A transição entre a vida que o menino tinha antes e a vida que terá depois dá-se pela viagem de trem:

Três dias depois da tragédia levaram-me para o engenho do meu avô materno. Eu ia ficar ali morando com ele. Um mundo novo se abrira para mim. Lembro-me da viagem de trem e de uns homens que iam conosco no mesmo carro. [...] Todos olhavam para mim com um grande pesar. [...] 0 trem era para mim uma novidade. Eu ficava na janelinha do vagão a olhar os matos correndo, os postes do telégrafo, e os fios baixando e subindo. [...] E na primeira parada deixamos o trem, com grande saudade para mim (REGO, 2013, p. 31).

É natural que a criança órfã se apegue à primeira pessoa que lhe dê um pouco de afeto e ternura. Para Carlinhos, essa substituta natural da mãe ele encontrou em tia Maria, cuja atenção, mimos e cuidados de certo modo amenizaram o vazio causado pela orfandade.

179 Piedade devido à situação vivida pela criança, sendo ainda tão pequena e já órfã; desconfiança por carregar uma herança genética de seu pai, "um louco". 
A moça que se parecia com a minha mãe, e que era sua irmã mais nova, me levou para mudar a roupa: "Agora vou ser a sua mãe. Você vai gostar de mim. Vamos, agora não chore. Seja homem". E me abraçou e me beijou, com uma ternura que me fez lembrar os beijos e abraços de minha mãe (REGO, 2013, p. 31).

Por outro lado havia a tia Sinhazinha, tia-avó de Carlinhos, por quem o menino nutria um sentimento ruim. Não fazendo uso de meias palavras, foi desta forma que o narrador primeiro a descreveu:

\begin{abstract}
Era um temperamento esquisito e turbulento. [...]. Era ela quem tomava conta da casa do meu avô, mas com um despotismo sem entranhas. Com ela estavam as chaves da despensa, e era ela quem mandava nas negras no serviço doméstico. Em tudo isso, como um tirano. Meu avô, que não se casara em segundas núpcias, tinha, no entanto, esta madrasta dentro de casa. Logo que a vi pela primeira vez, com aquele rosto enrugado e aquela voz áspera, senti que qualquer coisa de ruim se aproximava de mim. Esta velha seria o tormento da minha meninice. Minha tia Maria, um anjo junto daquele demônio, não tinha poderes para resistir às suas forças e aos seus caprichos. As pobres negras e os moleques sofriam dessa criatura uma servidão dura e cruel (REGO, 2013, p. 36).
\end{abstract}

Os termos com que ele se refere à tia, como "despotismo", "tirano", "madrasta", "tormento”, “demônio”, “criatura”, associados à descrição de duas características físicas típicas de uma "bruxa" - "rosto enrugado" e "voz áspera" - revelam a imagem assustadora que o menino tivera ao se deparar com essa figura, que agora faria parte da sua meninice. Esse contraste entre a "fada boa" e a "fada má" - a tia Maria, "um anjo", e a tia Sinhazinha, "um demônio" - é um ingrediente a mais para alimentar os sentimentos ambíguos que despontarão ao longo dos anos no coração do menino.

Assim, mesmo cercado de carinhos e mimos pela tia Maria, Carlinhos não se despoja facilmente da tristeza e da revolta que a tragédia familiar lhe causara, e que se 
transformariam, ao longo do tempo, em melancolia e ceticismo, dois traços de personalidade revelados pelo próprio personagem, que o acompanham durante toda a sua história.

Caracterizada por um estado de abatimento e tristeza proveniente na maioria das vezes por um sentimento de perda, a melancolia está associada, muitas vezes à perda da alegria, de um ente querido, de uma situação favorável, ou ainda relacionada a circunstâncias de extremo estresse. O Dicionário Houaiss traz as seguintes definições para o termo:

(1) Estado mórbido caracterizado pelo abatimento mental e físico que pode ser manifestação de vários problemas psiquiátricos, hoje considerado mais como uma das fases da psicose maníaco-depressiva;

(2) Estado de grande tristeza e desencanto geral; depressão; (3) Derivação, por extensão de sentido: sentimento de vaga e doce tristeza que compraz e favorece o devaneio e a meditação. ${ }^{180}$

Carlinhos descreve seu estado de melancolia e tristeza em diversas passagens de sua história, sendo a primeira delas bem no início da narrativa, quando discorre sobre a morte da mãe e a amargura de pensar em sua figura "angelical" integrando as cruas páginas policiais dos jornais:

O seu destino fora cruel: morrer como morreu, vítima de um excesso de cólera do homem que tanto amara; e depois, ela, cheia de pudor e de recato, a encher as folhas de sensação com o seu retrato, com histórias mentirosas de sua vida íntima. A morte de minha mãe me encheu a vida inteira de uma melancolia desesperada (REGO, 2013, p. 28).

180 Dicionário Houaiss eletrônico. 
Assim, desde pequeno o personagem já demonstra ter noção do sentimento que o invade nessa época para se manifestar muitas vezes depois, já no engenho, em seus devaneios pela horta e pelo pomar, ou em seus longos "passeios de carneiro":

Era um menino triste. Gostava de saltar com os meus primos e fazer tudo o que eles faziam. Metia-me com os moleques por toda parte. Mas, no fundo, era um menino triste. Às vezes dava para pensar comigo mesmo, e solitário andava por debaixo das árvores da horta, ouvindo sozinho a cantoria dos pássaros (REGO, 2013, p. 86).

A carência afetiva do menino faz-se notar em diversas passagens do texto, reveladas em situações de "apego e abandono", e que são responsáveis, respectivamente, por fechar e abrir as feridas que a orfandade precoce lhe proporcionara, alimentando seu sentimento de solidão, melancolia e isolamento. Um exemplo dessa sensação de apego e abandono é o episódio que narra a visita das primas da cidade, filhas de tio João, ao engenho ${ }^{181}$, quando Carlinhos, então com apenas oito anos de idade e com seu "verde coração de menino", encanta-se por Maria Clara:

O meu coração de oito anos agora se arrebatava com mais violência. Estavam no engenho passando uns tempos umas parentas do Recife. Era uma gente que não tirava as meias da manhã à noite, falava francês [...]. Para mim a visita viera me aperrear o coração de menino. Maria Clara, mais velha que eu, andava comigo pela horta. Menina da cidade, encontrara um bedéquer amoroso para mostrar-lhe os recantos do Santa Rosa. [...] E o meu amor crescia, dilatava o meu verde coração de menino (REGO, 2013, p. 112-115).

${ }^{181}$ Capítulo 34, p. 112-116. 
Foram dias de "conversas compridas" e exageradas à sombra das gameleiras $^{182}$ e dos cajueiros, e até um beijo roubado, da primeira namorada. Porém, quando a prima retorna com sua família para Recife, após a temporada no engenho, o menino sofre sua primeira desilusão amorosa:

As meninas do tio João já estavam em despedidas. Para a semana voltariam para Recife. [...] De manhã, o carro de boi saía com o povo para a estação. [...] Para menino não havia lugar. Maria Clara nem parecia que me queria bem, toda satisfeita, sentada no carro. Pensava que ela estivesse triste como eu. Mas qual! Alegre com a viagem, bem contente no meio do alvoroço das despedidas [...] Quando cheguei, de volta, não sei quem, na cozinha: "Ficou sem namorada, hein?" As lágrimas chegaram-me aos olhos, e disparei num choro que não contive (REGO, 2013, p. 115-116).

Mais do que a simples dor pelo amor perdido, a diferença de intensidade entre o seu sentimento e o de Maria Clara ("Pensava que ela estivesse triste como eu"), e a zombaria com a qual seu martírio foi tratado ("Ficou sem namorada, hein?") acentuam o sofrimento de Carlinhos, tornando o menino ainda mais triste e melancólico. 0 próprio narrador classifica esse episódio como "a primeira angústia” da sua vida:

Dormi à noite, com Maria Clara junto de mim. Os sonhos de um menino apaixonado são sempre os mesmos. Acordei-me, porém, com a primeira angústia de minha vida. Os pássaros cantavam tão alegres no gameleiro, porque talvez não soubessem da minha dor. Senti nesse meu despertar de namorado um vazio doloroso no coração. Tinha perdido a minha companheira dos cajueiros. E chorei ali entre os meus lençóis lágrimas que o amor faria ainda muito correr dos meus olhos (REGO, 2013, p. 116).

1820 autor usa o termo "gameleiros". 
Esse capítulo isolado ${ }^{183}$, que narra a estada das filhas de tio João no engenho Santa Rosa, nos remete, em alguns aspectos, ao episódio da visita das sobrinhas de dona Inácia à casa da tia, em "Negrinha". Em ambas as ocasiões, a rotina da casa é alterada com a chegada das "visitas", levando os protagonistas de ambas as narrativas a conhecerem um sentimento ainda não experimentado antes: uma felicidade sublime. No caso de Carlinhos, isso se revela na descoberta do amor; no caso de Negrinha, na descoberta de ser criança, de ser humana, pelo ato de brincar. Porém quando a temporada acaba, e as visitas retornam a seus lares, o vazio proporcionado por sua ausência torna-se insuportavelmente maior do que a rotina previamente instalada, causando profunda desilusão aos protagonistas. No caso da personagem lobatiana, a decepção gera uma depressão tão grande que se torna irreversível, causando-lhe a morte. Para Carlinhos, a partida de sua "primeira namorada" reconduz o personagem ao seu estado natural de melancolia e solidão.

Outra perda significativa de Carlinhos, que contribui para acentuar seu isolamento, é a privação de sua liberdade, quando ele começa a sofrer de "puxado"184, doença que o deixava por longos dias afastado das brincadeiras ao ar livre com os primos ou os "moleques" do engenho. Enclausurado dentro de casa, o menino se fecha ainda mais dentro de si, perdido em seus pensamentos:

Já estava maior, quando comecei a sofrer de puxado. Uma moléstia horrível que me deixava sem fôlego, com o peito chiando, como se houvesse pintos sofrendo dentro de mim. Tenho uma impressão de terror das minhas noites de asmático, dos meus dias compridos em cima da cama, dos vomitórios abomináveis que me davam. Eram acessos de mais de três dias. Depois a convalescença, sem poder pisar no terreiro, sem ir ao alpendre por causa do mormaço, do sereno, dos chuviscos. [...] Mandavam ao meu quarto, para brincar comigo, os moleques menores, mas eles se enjoavam daquela companhia de enfermo e me deixavam sozinho, me abandonavam. E, sozinho, começava a vencer o tempo com as minhas cismas de menino. [...] As noites pareciam-me uma eternidade. [...] Essas noites de puxado envelheciam a minha meninice [...] (REGO, 2013, p. 99-101).

${ }^{183}$ Capítulo 34, p. 112-116.

${ }^{184}$ Nome usado pelo narrador para designar a asma, doença de que sofria o personagem. 
Desse modo, sua consciência sobre o "envelhecimento de sua meninice" no auge da infância mostra como o personagem vai despedindo-se precocemente desse período da vida, que deveria ter como características mais marcantes a alegria, o desprendimento, a ausência de preocupações.

Por outro lado, morte e doença - situações que também são comumente associadas ao sentimento de melancolia - acompanham a história de Carlinhos desde o seu princípio. 0 assassinato da mãe e a loucura do pai, deflagrados já no primeiro capítulo da narrativa, não são os únicos exemplos de situações de morte e doença às quais o menino será exposto ao longo de sua infância. Logo após chegar ao engenho, Carlinhos testemunha outras mortes, como a da prima Lili ${ }^{185}$, e a de trabalhadores do engenho, seja por doença186 ou facada187. A "matança de porcos e carneiros" para o casamento de tia Maria, incluindo o sacrifício de seu carneiro de estimação, também é motivo para tristeza e abatimento ("Saí da matança com a alma doente", p. 125). A linha entre as enfermidades do corpo e as da alma é muito tênue em sua descrição, e revelase tanto em seu "puxado" e na doença venérea que contrai mais tarde, como nos momentos de profunda depressão e no receio de ser "doente mental", como seu pai:

Destes problemas de hereditariedade me aproximava com pavor. Também tinha um pai a quem podia puxar. E todos no engenho pensavam nisto, porque me cercavam de cautela e precauções. [...] Os meus pensamentos vinham assim, de fontes envenenadas de pessimismo. Menino, e pingando em cima da minha infância este ácido corrosivo que me secava a alegria de viver. [...] Os pensamentos ruins principiavam a fazer ninho no meu coração. [...] Por debaixo dos sapotizeiros, nas sombras amigas destas árvores, à espera dos canários, só pensava pensamentos maus. Criava assim dentro de mim uma pessoa que não era a minha. As reclusões forçadas, a que submetiam o menino que precisava de ar e de sol, iam perdendo mais a minha alma que salvando o meu corpo [...] (REGO, 2013, p. 120-121).

\footnotetext{
185 Morte da prima Lili. Capítulo 8, p. 37-38.

186 Morte do trabalhador do engenho (sem nome). Capítulo 25, p. 87-88.

187 Morte do negro Gonçalo. Capítulo 38, p. 132.
} 
Esses "pensamentos maus" acompanham Carlinhos na maior parte de seus momentos de solidão, exacerbando sua depressão e afastando-o lentamente da alegria inerente à infância. Isso fica mais claro no relato de seus passeios de carneiro, que poderiam ser usados para aguçar sua imaginação de menino, transportando-o a um mundo fantástico de cavaleiros e soldados em suas montarias, desbravando terras inexploradas rumo ao desconhecido... Porém o que acontece é justamente o contrário; uma viagem para dentro de si mesmo, percorrendo um terreno fertilizado pela depressão e pela tristeza, onde o menino só encontra lugar para meditações e "pensamentos de melancólico":

Esses passeios, sozinho, pela estrada, montado no meu Jasmim penteado, arrastava-me aos pensamentos de melancólico. Deixava a dócil cavalgadura a rédeas soltas, e fugia para dentro do meu íntimo. Pensava em coisas ruins [...](REGO, 2013, p. 93-94).

As "coisas ruins" a que o narrador se refere nesse trecho eram especialmente pensamentos sobre a morte, em lucubrações sobre uma possível ausência de seu avô, que deixaria desamparadas muitas famílias que viviam no engenho ou em seu entorno, sob a sua proteção - preocupações estas que geralmente são típicas de adultos, e não de crianças.

Outra angústia revelada durante os passeios era o iminente e inevitável distanciamento de sua querida tia Maria, que em breve se casaria, deixando-o "órfão" mais uma vez. Desse modo, a despedida da sua "segunda mãe", sua "fada boa", proporcionando-lhe um vazio que seria provavelmente preenchido pela sombra daquela que infernizava sua infância, a Tia Sinhazinha, a "bruxa má", são mais ingredientes que marcam negativamente, com esse sentimento de perda, a infância do menino:

A casa estava cheia de gente. Era um zum-zum por toda parte. Buliam comigo: "Vai ficar sozinho, hein? Quem vai tomar conta dele agora é a velha Sinhazinha". Não quis ver o casamento. Corri chorando para a minha cama. [...] Fui dormir. Minha tia Maria me beijou chorando. E de 
manhã, quando me acordei, ainda a música tocava para a dança. [...] Maria Menina dava os seus adeuses... [...] E me beijou, me abraçou não sei quantas vezes, enquanto eu chorava num pranto desesperado. [...] No outro dia amanheceu chovendo, e o Santa Rosa a coisa mais triste do mundo. Tudo vazio para mim, tudo oco, sem os cuidados, os beijos e as cavilações da minha tia Maria (REGO, 2013, p. 127).

Além da melancolia, uma característica que também se manifestou desde cedo em Carlinhos foi o ceticismo. Na acepção do termo por extensão de sentido, ceticismo pode ser entendido como "falta de crença; descrença, incredulidade, dúvida" 188.

Apesar do fato de as crianças apresentarem geralmente grande facilidade para aderir às fantasias, ao encantamento, ao mundo do faz de conta, Carlinhos mostrou-se desde cedo bastante cético com relação ao mundo, ao destino, à “justiça divina”. Logo no início da narrativa ele deixa clara essa sua visão:

A morte de minha mãe me encheu a vida inteira de uma melancolia desesperada. Por que teria sido com ela tão injusto o destino, injusto com uma criatura em que tudo era tão puro? Esta força arbitrária do destino ia fazer de mim um menino meio cético, meio atormentado de visões ruins (REGO, 2013, p. 28).

Apesar de ter aprendido "algumas rezas" e o "padre-nosso" com tia Maria, além daquilo que já sabia sobre religião, fruto das lembranças de conversas antigas com sua mãe, Carlinhos não se desenvolvera espiritualmente, conhecendo apenas esporádicas passagens bíblicas e tradições religiosas católicas, mas nunca se aprofundando no catecismo. Por outro lado, alimentava fantasias das histórias que lhe contavam, especialmente aquelas de lobisomem ou de zumbis que encarnavam almas de animais, e ficavam rondando pelo engenho. E porque lhe contavam as histórias com tantos detalhes e tanta credulidade, Carlinhos acreditava nelas "com mais convicção do que acreditava em Deus" (p. 69):

${ }^{188}$ Dicionário Houaiss eletrônico. 
O lobisomem existia, era de carne e osso, bebia sangue de gente. Eu acreditava nele com mais convicção do que acreditava em Deus. Ele ficava tão perto da gente, ali na Mata do Rolo, com as suas unhas de espetos e os seus pés de cabra! Deus fizera o mundo somente. Era distante dos nossos medos [...] (REGO, 2013, p. 70).

Assim, além da exacerbada melancolia que tomou conta de boa parte da sua infância, e do ceticismo que o afastava de Deus ao mesmo tempo que o aproximava das "trevas", outra característica que se revelará ao longo da narrativa é a perda prematura da inocência e do encantamento típicos da infância, dando lugar ao que o protagonista chama de "porcaria", "coisa ruim", "vício visguento". Para o narrador, sua "ausência perigosa de religião" e a "miséria de sentimentos religiosos" não o levavam "a temer os pecados" (p. 121).

As primeiras experiências mais "sensuais" ou mesmo "sexuais" de Carlinhos são muito precoces e estão associadas a duas pessoas que, curiosamente e de maneiras bem distintas, fizeram parte de sua "educação". A primeira, uma mulher "morena e bonita", chamada Judite, que fora designada para ensiná-lo a ler, provocando no menino mais curiosidade para o despertar da sua libido do que propriamente pelas letras:

Botaram-me para aprender as primeiras letras em casa dum dr. Figueiredo [...]. Tinha o meu mestre uma mulher morena e bonita, que me beijava todas as vezes que eu chegava, que me fazia as vontades: chamava-se Judite. Gostava dela diferente do que sentia pela minha tia Maria. Ela sempre que me ensinava as letras debruçava-se por cima de mim. E os seus abraços e os seus beijos eram os mais quentes que eu já tinha recebido. [...] E meu coração sentiu-se cheio de uma afeição estranha pela sua mulher. Era tão terna para mim, me punha no colo para me agradar, para me dizer que me queria um bem de mãe" [...] Foi ali com ela, sentindo o cheiro de seus cabelos pretos e a boa carícia de suas mãos morenas, que aprendi as letras do alfabeto. Sonhava com ela de noite, e não gostava dos domingos, porque ia ficar longe de seus beijos e abraços (REGO, 2013, p. 54). 
O segundo, um "moleque" do engenho de seu avô, chamado Zé Guedes, que, incumbido de acompanhar o menino à escola, no caminho ensinava-lhe mais do que os professores, contando particularidades das experiências suas e alheias com as mulheres da vida, além de iniciá-lo nos "mistérios do sexo" na teoria e na prática, com "aulas públicas de amor" no curral:

O outro mestre que eu tive foi o Zé Guedes, meu professor de muita coisa ruim. Levava-me e trazia-me da escola todos os dias. E na meia hora que ficava com ele, de ida e volta, aprendi coisas mais fáceis de aprender que a tabuada e as letras. Contava-me tudo que era história de amor, sua e dos outros. "Ali mora Zefa Cajá". E lá vinha com os detalhes, com as coisas erradas da vida desta mulher. Às vezes parava na porta, era uma conversa comprida, cheia de ditos e de semvergonhices. [...] Eu gostava mesmo de ouvir o bate-boca imundo. [...] Eram assim as minhas lições de porcaria com aquele mestre que não se contentava com o lado teórico de seu magistério e também dava as suas lições de coisas (REGO, 2013, p. 55-56).

O lado prático do "aprendizado" eram as experiências libidinosas com cabras e vacas, de que Carlinhos era levado a participar pelos moleques e primos mais velhos:

Tínhamos as nossas cabras e as nossas vacas para encontros de lubricidade. A promiscuidade selvagem do curral arrastava a nossa infância às experiências de prazeres que não tínhamos idade de gozar. Era apenas uma buliçosa curiosidade de menino [...]. Uma tarde o primo Silvino me disse: "Hoje vamos fazer porcaria no curral". De fato, à boca da noite, quando o gado chegado do pastoreador descansava, uns deitados e outros parados a olhar o chão, eu vi o primo Silvino trepado na cerca, procurando pôr-se por cima de uma vaca mansinha. Nós todos ficávamos de longe, mudos e sôfregos, como se fôssemos cúmplices de um crime (REGO, 2013, p. 56-57). 
Desse modo, Carlinhos ia perdendo sua inocência e viciando-se nas conversas "picantes sobre as coisas do sexo", e nas diversas atividades a que era convidado a participar ou assistir, primeiro no curral, depois nos arredores da casa grande, na "bagaceira", onde se instalava um verdadeiro "lupanar para jardim de infância": "a nossa doce inocência perdia-se assim nessas conversas bestas, o contato libidinoso com os moleques da bagaceira" (p. 77).

O exemplo de seu tio Juca no seu relacionamento com mulheres também ajudou a despertar em Carlinhos seu lado mais obsessivo pela sexualidade. Em trechos de conversas ouvidas e em episódios esporádicos que o menino testemunhava, não era difícil perceber o envolvimento do tio com mulheres da senzala e prostitutas. 0 episódio em que o menino espia conteúdos pornográficos no quarto do tio é também determinante para aguçar sua curiosidade acerca dos mistérios e das contradições do sexo, uma vez que os postais obscenos, "objeto da proibição", lhe causam ao mesmo tempo sentimentos contraditórios, como repulsa e atração:

Num dia que ele me deixou sozinho, corri sôfrego para o objeto da proibição; uma coleção de mulheres nuas, de postais em todas as posições da obscenidade. Não sei para que meu tio guardava aquela nojenta exposição de porcarias. Sempre que sucedia ficar sem ele no quarto, era para os postais imundos que me botava. Sentia uma atração irresistível por aquelas figuras descaradas de meu tio Juca. [...] Mas ficava-me de seus aposentos uma saudade ruim daquelas mulheres e daqueles homens indecentes (REGO, 2013, p. 121).

Assim, do mesmo modo que os postais causavam-lhe um sentimento de repugnância e aversão - "nojenta exposição de porcarias"; "postais imundos"; "figuras descaradas"; "mulheres e homens indecentes" -, tornavam-se objeto de desejo e sedução: "atração irresistível"; "saudade ruim".

Para completar a iniciação sexual de Carlinhos, haveria ainda a negra Luísa, "uma espécie de anjo mau" da sua infância, que o arrastava para "coisas ignóbeis" na hora de dormir: 
A moleca me iniciava, naquele verdor de idade, nas suas concupiscências de mulata incendiada de luxúria. Nem sei contar o que ela fazia comigo. Levava-me para os banhos do rio, sujando minha castidade de criança com os seus arrebatamentos de besta. [...] Só pensava nos meus retiros lúbricos com o meu anjo mau, as masturbações gostosas com a negra Luísa. E comecei a querer-lhe um bem esquisito. [...] Era um vício absorvente o meu pegadio com a negra Luísa. O sexo impunha-me essa escravidão abominável (REGO, 2013, p. 121).

E, por fim, após as suas aulas teóricas e práticas com as vacas e cabras do curral, da manipulação de conteúdos pornográficos de seu tio, e da iniciação sexual e pedófila com a negra Luísa, Carlinhos teve sua primeira experiência "como homem", aos doze anos de idade, quando começou a frequentar a casa da prostituta Zefa Cajá, numa “ânsia misturada de medo e de vergonha” para "fazer coisa ruim” (p. 134):

Ela me acariciava com uma voracidade animal de amor: dizia que eu tinha gosto de leite na boca e me queria comer como uma fruta de vez. [...] Era mesmo um vício visguento aquele dos afagos de Zefa Cajá (REGO, 2013, p. 134).

A experiência sexual com a rapariga, além de contribuir de vez para a perda de sua infância e da castidade que ainda lhe restava, trouxe como consequência o infortúnio de que ele viesse a conhecer de perto - e cedo demais - uma "doença do mundo", a sífilis ${ }^{189}$, que o transformou de criança em homem, sem outras etapas intermediárias, tanto para a imagem que ele fazia de si mesmo, como para os olhos dos outros:

189 No texto a doença venérea não é citada com esse nome: é referida sempre como "doença do mundo" ou "doença de homem" e uma vez, com o termo "gálico". 
A doença do mundo me operara uma transformação. Via-me mais alguma coisa que um menino; e mesmo já me olhavam diferente. Já não tinham para mim as condescendências que se reservam às crianças. As negras faziam-me de homem (REGO, 2013, p. 136).

Desse modo Carlinhos despede-se de sua infância, já fragilizada pelas perdas que tivera ao longo do caminho: a perda da alegria, causada especialmente pela orfandade precoce e pelo cultivo da melancolia; a perda da fé, vinculada ao despreparo religioso, somada à revolta pela triste "peça" que o destino lhe reservou, e a perda da inocência, do encantamento, da castidade, que geralmente fazem da criança um ser ingênuo e puro, atributos que fora perdendo aos poucos, em sua curta vida de menino:

O sexo vestira calças compridas no seu Carlinhos. E o coração de um menino depravado só batia ao compasso de suas depravações. [...] Corria os campos como um cachorro no cio, esfregando a minha lubricidade por todos os cantos. [...] Perdera a inocência, perdera a grande felicidade de olhar o mundo como um brinquedo maior que os outros. Olhava o mundo através dos meus desejos e da minha carne (REGO, 2013, p. 137).

Assim, a partir do penúltimo capítulo do livro, em que revela a experiência vivida com a prostituta Zefa Cajá e se autointitula "homem", para referir-se a si mesmo, o narrador passa a usar e repetir uma série de adjetivos vinculados ao termo "menino", exemplos de expressões que comumente agora ouvia dos adultos, das negras, das pessoas que vinham a saber de sua doença, da sua vida depravada. Dessa forma, "menino enxerido", "menino danado", "menino safado" e "menino vadio" precedem o "menino perdido", denominação que o próprio protagonista usa para atribuir a si, na frase derradeira de sua narrativa. 


\subsection{Menino de Engenho e a jornada do herói ${ }^{190}$}

Apesar da tragédia que mudou radicalmente sua vida, ao menino Carlinhos a infância não lhe fora subtraída ou simplesmente "negada", como ocorre com a personagem Negrinha, analisada no capítulo anterior. Após a chegada ao engenho do avô, o protagonista de José Lins do Rego tem a oportunidade de desfrutar de momentos de prazer e alegria, com o carinho de sua tia Maria, com as brincadeiras com os meninos no pomar e no rio. Porém a melancolia que aos poucos toma conta de seu coração, os pensamentos que o levam para divagações insalubres, sua doença respiratória e sua vida desregrada no engenho fazem com que ele mesmo se considere uma criança "perdida”, sem referências, sem sossego.

Como ocorre em vários contos de fadas e contos populares, a orfandade tornou-se para Carlinhos o seu "chamado para a aventura"191. A viagem de trem transforma o menino em "herói", transportando-o da sua "zona de conforto" para o lugar onde ele precisará passar por provas para sobreviver.

Ao chegar ao engenho, com apenas quatro anos de idade, o protagonista é logo levado para um "batismo", um ritual de iniciação: "Você precisa ficar matuto!" (REGO, 2013, p. 32). Em sua nova vida, o menino tem a proteção da "fada boa" - a tia Maria - e a perseguição da "fada má" - a tia Sinhazinha. Passa por provações, como seu isolamento e seu "puxado". Vive intensamente um amor, com sua prima, Maria Clara. Pratica atos de heroísmo, quando, por exemplo, consegue salvar o trem repleto de passageiros de uma iminente colisão com uma pedra ${ }^{192}$. Trafega por terrenos desconhecidos, como as florestas e campos da imaginação em que habitam zumbis e lobisomens. Como Pinóquio, é levado por "maus elementos" a experimentar os "prazeres" da vida, mas em vez de ganhar orelhas e rabo de burro193, é punido com sua “doença de mundo". Ao final de sua

\footnotetext{
190 Um estudo mais aprofundado sobre a 'Jornada do Herói' e suas relações com a orfandade representada na literatura pode se depreender da leitura de minha dissertação de mestrado intitulada "Percurso do órfão na literatura infantil/juvenil, da oralidade à era digital: a trajetória do herói solitário" (CARDOSO, 2006).

191 Para Joseph Campbell, o "chamado para a aventura" significa que o destino convocou o herói e transferiu-lhe o centro de gravidade do seio da sociedade para uma região desconhecida. (CAMPBELL, J. O herói de mil faces, 7. ed., São Paulo, Cultrix, 2002, p. 66).

192 Capítulo 19, p. 66-67.

193 Na história de Collodi, Pinóquio é levado por más influências ao País das diversões ("Paese dei balocchi"), um lugar de divertimento só para crianças de oito a catorze anos, onde, depois de um tempo, todos se transformavam em burrinhos.
} 
saga, despede-se do menino, para então pegar o trem de volta, que o levará para uma nova aventura, desta vez no colégio interno ${ }^{194}$. A jornada do herói se completa: partida, iniciação, retorno ${ }^{195}$.

Muitas leituras podem ser depreendidas de Menino de Engenho. 0 romance inaugural de José Lins do Rego traz elementos sociais importantes, como o iminente declínio dos engenhos de cana-de-açúcar, o papel e lugar dos negros após a abolição da escravatura, o poder autoritário e patriarcal do "senhor do engenho", o convívio entre as crianças da casa grande e os "moleques da bagaceira", o cangaço, o relacionamento entre as "negras da senzala" e os trabalhadores do eito, entre outros. Nesta análise, porém, procuramos desvelar a representação da infância por meio do sentimento de perda, do "menino perdido", da infância perdida.

No romance, o equilíbrio entre humanismo e crítica social, associado à saga de uma criança órfã que desde muito cedo precisa enfrentar a dureza do mundo, podem ter sido os elementos responsáveis pela ampla divulgação e aceitação do livro196, não apenas no auge do movimento modernista, mas em todo o período que se sucedeu. Dessa forma Menino de engenho tornou-se uma referência do romance regionalista no século XX197, e Carlinhos, "menino perdido", anti-herói solitário, o protagonista que "Zé Lins inscreveu para sempre na galeria de personagens inesquecíveis da literatura brasileira"198.

\footnotetext{
${ }^{194}$ A história de Carlinhos continua no romance Doidinho (1933), em que são relatados seus anos de internato.

195 Para Joseph Campbell, a jornada do herói completa-se com três fases: partida, iniciação e retorno. (CAMPBELL, 2002, p. 57-249).

196 De acordo com o jornalista Marcos de Castro, Tristão de Ataíde teria dito, certa vez que as obras de José Lins do Rego seriam "as mais lidas de nossas letras modernas" "A emoção e a glória de um escritor" in: REGO, J.L. Menino de engenho. 105ª ed. Rio de Janeiro, José Olympio, 2013)

197 O livro está em sua 105a edição (Cia. das Letras, 2013).

${ }^{198}$ CASTRO, M. “A emoção e a glória de um escritor" in: REGO, 2013, p. 16.
} 
"Esqueceram de tudo e foram iguais a todas as crianças, cavalgando os ginetes do carrossel".

Jorge Amado (1937) 
Capítulo 4

Entre meninos e homens: infância e sociedade em Capitães da Areia 


\title{
Capítulo 4
}

\section{Entre meninos e homens: infância e sociedade em Capitães da Areia}

\begin{abstract}
"A criança e o adolescente têm direito a proteção à vida e à saúde, mediante a efetivação de políticas sociais públicas que permitam o nascimento e o desenvolvimento sadio e harmonioso, em condições dignas de existência. [...] É dever da família, da comunidade, da sociedade em geral e do poder público assegurar, com absoluta prioridade, a efetivação dos direitos referentes à vida, à saúde, à alimentação, à educação, ao esporte, ao lazer, à profissionalização, à cultura, à dignidade, ao respeito, à liberdade e à convivência familiar e comunitária".
\end{abstract}

Estatuto da Criança e do Adolescente ${ }^{199}$

"[...] children in the English sense do not exist in Brazil. The smallest girls had bangles and bracelets, and boys at eight have their cigarettes. I came across a batch of boys returning from school one afternoon. One little fellow, apparently about seven years of age, turned out of his pockets a collection of sweets, oranges, and cigarettes, in which he indulged by turns. No one seemed to express the slightest disapproval of so small a boy smoking. The language some of these little boys use is appalling, though I must admit I consider that [...] they are for the most part unconscious that they are using bad language at all. Games seem to be unknown to them. The only sort of play they ever take part in is leap-frog, and in this but occasionally".

E. R. Pearce Edgcumbe 200

199 Estatuto da Criança e do Adolescente. Lei Federal № 8.069, de 13 de julho de 1990, Art. 7oㅡ, Capítulo 1 e Art. 4ํㅜㄴ, Título 1. Presidência da República, Casa Civil, Subchefia para Assuntos Jurídicos.

200 EDGCUMBE, E. R. P. Zephyrus: A holiday in Brazil and on the River Plate. London, Chatto \& Windus, Piccadilly, 1887, p. 49-50. “[...] Crianças, no sentido literal da palavra, não existem no Brasil. Meninas bem novas usam pulseiras e braceletes e meninos de oito anos já fumam. Uma tarde, passei por um grupo de rapazinhos voltando da escola. Um garoto de aparentemente sete anos de idade tirou do bolso uma porção de coisas: doces, laranjas e cigarros, regalando-se sucessivamente. Ninguém demonstrou qualquer sinal de desaprovação pelo fato de um menino tão novo estar fumando. A linguagem de alguns desses meninos é deplorável, embora eu deva admitir que [...] eles talvez não se deem conta de que estão usando expressões chulas. Brincadeiras ou jogos não lhes são familiares. 0 único tipo de brincadeira que parecem conhecer é "pular sela" (também conhecida como "pular carniça"), e, mesmo assim, brincam apenas esporadicamente". 


\subsection{Sociedade e infância no Brasil: a rua como lar}

As citações que abrem este capítulo pertencem a tempos e contextos bastante distintos. A primeira delas, composta por dois excertos retirados do Estatuto da Criança e do Adolescente (1990), dista mais de cem anos da segunda, extraída do livro de viagens Zephyrus: a holiday in Brazil and on the River Plate (1887), escrito por Sir Edward Robert Pearce Edgcumbe 201 , no fim do século XIX. Entretanto, apesar de 130 anos separarem os dias atuais da publicação desse texto - anos em que, vale ressaltar, muito se discutiu sobre a questão da infância no Brasil e no mundo ${ }^{202}$-, é interessante perceber como a cena retratada pelo viajante inglês poderia ser facilmente flagrada ainda hoje, nas ruas de uma grande cidade brasileira.

Analisando estudos sobre a infância no Brasil no final do século $\mathrm{XX}$, a antropóloga Miriam Moreira Leite ${ }^{203}$ revela a existência de uma grande mobilização nacional nos debates acerca dessa faixa etária, incluindo a participação de vários setores da sociedade. Segundo a autora, nesse período "a infância tornou-se uma questão candente para o Estado e para as políticas não governamentais, para o planejamento econômico e sanitário, para legisladores, psicólogos, educadores e antropólogos, para a criminologia e para a comunicação em massa" (LEITE, 2011, p. 19). Para justificar a importância que se passou a dar à infância, especialmente à "infância desvalida", cita como exemplo os trabalhos apresentados na 20aㅡ Reunião Brasileira de Antropologia, ocorrida em Salvador, em 1996, em que, à exceção de alguns estudos "sobre família e educação formal”, "a maioria focalizou os 'meninos de rua', o trabalho infantil, a pobreza, a delinquência e a violência, a exclusão da cidadania e as políticas públicas", e as implicações que toda essa situação apresenta (p. 19).

O drama das crianças de rua no Brasil, porém, não é uma exclusividade do nosso tempo. Embora aponte o final do século XX como um período profícuo de reflexão

\footnotetext{
201 Sir Edward Robert Pearce Edgcumbe (1851-1929), autor inglês.

202 Foi ao longo do século XX que se concentraram as discussões sobre os direitos da criança, e sobre a importância da intervenção do Estado em sua proteção, a regulamentação do trabalho infantil e o estabelecimento de parâmetros específicos para essa faixa etária, por meio de decretos, estatutos e leis. 203 Miriam Lifchitz Moreira Leite (1926-2013), antropóloga. Integrante do GRAVI - Grupo de Antropologia Visual (USP). Formada em História Econômica, com pós-doutorado pela Eastman Foundation, foi membro da assessoria em fotografia histórica do Laboratório de Imagem e Som em Antropologia e Professora doutora do grupo de pesquisa em imagem do Laboratório de Imagem e Som em Antropologia.
} 
e estudo acerca da criança, Leite admite que muitos dos problemas apontados "não são nem novos, nem menos trágicos do que em séculos anteriores" (LEITE, 2011, p. 20), citando o abandono de crianças e o infanticídio como "práticas encontradas entre índios, brancos e negros em determinadas circunstâncias", e a entrega de crianças em "rodas de expostos" (p. 20), como costume existente no Brasil desde o século XVIII.

Maria Rosilene Alvim²04 e Licia do Prado Valladares ${ }^{205}$, pesquisadoras das áreas de Antropologia e Sociologia Urbana, também avaliam o problema da infância desvalida ou do menor abandonado como assunto proveniente de longa data, citando o século XIX como aquele que, devido ao processo de industrialização europeu, especialmente na França e na Inglaterra, trouxe à tona questões acerca tanto das crianças exploradas pelas fábricas e indústrias, como das abandonadas.

Em ensaio publicado em 1988 - escrito, portanto, na efervescência das discussões mundiais acerca da infância206 -, as autoras afirmam que "a presença marcante de crianças e jovens no atual cenário das grandes cidades brasileiras se faz acompanhar da proliferação de textos sobre a questão do menor", fazendo supor que estaríamos "diante de um fenômeno recente, seguido de perto pelo olhar arguto do cientista social". As autoras alertam, porém, que "um exame cauteloso e detalhado da produção intelectual voltada para a análise da infância" indica tratar-se de "um tema presente desde o século XIX, tanto no Brasil como no exterior", como é possível depreender de diversos documentos escritos por "médicos, juristas, políticos, cronistas, jornalistas e escritores em geral”, preocupados com as possíveis intervenções sobre a chamada "questão social".

Para as autoras, basta "um olhar para o passado" para entender que a presença de crianças nas ruas das grandes cidades "foi um fenômeno recorrente em contextos de rápida industrialização e desenvolvimento urbano acelerado" (ALVIM \& VALLADARES, 1988, p. 3):

\footnotetext{
${ }^{204}$ Maria Rosilene Alvim, Professora Associada da UFRJ, Doutora em Antropologia Social.

${ }^{205}$ Licia do Prado Valladares, pesquisadora visitante do PPCIS (Programa de pós-graduação em Ciências Sociais) da UERJ. Doutora em Sociologia pela Universite de Toulouse I (Sciences Sociales). Fundadora do URBANDATA e Professora emérita da Universidade de Lille.

206 A Convenção sobre os Direitos da Criança adotada pela Assembleia Geral das Nações Unidas seria realizada no ano seguinte, em novembro de 1989, sendo oficializada como lei internacional em 1990 e ratificada por 196 países.
} 
Na França e na Inglaterra do século XIX as crianças faziam parte da reflexão sobre as condições de vida das camadas populares no contexto do capitalismo emergente. Tanto se falava das crianças exploradas pelo trabalho industrial como de crianças abandonadas, vadias, mendigas, que integravam o universo cruel da grande cidade e que foram retratadas com grande realismo por escritores famosos da época (ALVIM \& VALLADARES, 1988, p. 3).

Ainda de acordo com Alvim \& Valladares, em afirmação baseada em estudos do sociólogo francês Jacques Donzelot (1980), o debate sobre a questão da criança abandonada já se fazia presente "desde meados do século XVIII", quando

a pauperização e a miséria se associam na geração do abandono; a criança nascida de relações ilegítimas, num quadro de péssimas condições de habitação, num ambiente onde a promiscuidade e o vício predominam, tem como destino "natural" o mundo dos despossuídos, dos desordeiros [...]. Em oposição a este mundo da desorganização social e como a tábua possível de "salvação" da infância da classe trabalhadora, é apresentado o universo fabril, simbolizando o trabalho, a disciplina e a ordem (ALVIM \& VALLADARES, 1988, p. 4).

Desse modo, para as autoras, surgem para a criança "duas realidades possíveis": a primeira, pautada pela família e pela fábrica; a segunda, pela criminalidade, pela ausência de trabalho e pelo abandono do lar. Desse modo, em vista desta segunda realidade, "a rua aparece como o principal agente de socialização" desses menores (ALVIM \& VALLADARES, 1988, p. 4).

Fabiana Tavares ${ }^{207}$, analisando historicamente as concepções de infância na sociedade britânica, volta ainda um século atrás para lembrar que

207 Fabiana Tavares, Doutora em Letras (Estudos Comparados de Literaturas de Língua Portuguesa), estudou em sua tese de doutorado representações de infância da classe trabalhadora na literatura infantil e juvenil. 
a presença de crianças de rua, vagabundos e pobres é antiga conhecida da sociedade britânica, e foi, em várias ocasiões, objeto de discussão do governo, de industriários e de grupos filantrópicos. Com o aumento da oferta de mão de obra e a diminuição dos salários, a mendicância passou a ser praticada como forma de complementar a renda familiar dos pobres. Ainda no século XVII, a densidade demográfica de jovens pobres, cujos destinos eram a criminalidade ou a inatividade, do ponto de vista utilitário, era pauta de discussão para os governantes. Quando a situação das grandes cidades, como Londres e Manchester, tornou-se insuportável, a saída foi enviar as crianças e jovens dos pobres para a colônia norte-americana (TAVARES, 2014, p. 15).208

Voltando ao Brasil e ao final do século XX, em estudo sobre meninos e meninas em situação de risco, Carlos Nelson dos Reis e Jane Cruz Prantes 209 afirmam que "a rua inspirou muitos poetas, revolucionários, sanitaristas e, há aproximadamente duas décadas, vem fomentando trabalhos acadêmicos ávidos por descreverem seus mistérios" (REIS \& PRANTES, 1999, p. 54). Nessa pesquisa cujo objetivo declarado é "abordar o cotidiano da infância e juventude em situação de risco", os autores relembram que o problema da desigualdade social no Brasil "tem origem na nascente do seu processo histórico", não se tratando, portanto, "de nenhum fenômeno contemporâneo" (p. 45). De acordo com a pesquisa,

a historiografia econômica brasileira mostra que as origens das desigualdades remontam ao período colonial: uma agricultura de exportação composta de grandes propriedades dedicadas à monocultura, o que tinha como resultante um modelo de crescimento concentrador. Logo as origens da concentração da renda no país encontram-se no período colonial. $\mathrm{E}$ as mudanças no cenário político e na estrutura produtiva ocorridas nas fases seguintes vão acentuar o padrão de desigualdade, isso, tanto no Império como no período Republicano (REIS \& PRANTES, 1999, p. 45).

208 Estudo baseado em Cunningham, H. The Invention of Childhood. London: BBC, 2006.

209 Carlos Nelson dos Reis, Diretor do Instituto de Pesquisa e Desenvolvimento da PUCRS, Professor do Departamento de Economia da Faculdade de Administração, Contabilidade e Economia da Universidade; Jane Cruz Prantes, Doutora em Serviço Social pela PUCRS; Pós-doutoranda em Serviço Social da PUCSP, Professora e Coordenadora do Programa de Pós-Graduação em Serviço Social da PUCRS - PPGSS, pesquisadora do Núcleos de Pesquisa em Economia e Políticas Sociais. 
Para Maria Filomena Gregori210, "descrever as experiências, a situação e o modo de vida de meninos de rua no Brasil" é uma tarefa que impõe desafios, pois é preciso "enfrentar um problema de definição: [...] a tendência de associar a carência material à ausência de proteção familiar e, não raras vezes, à adoção de condutas infratoras" (GREGORI, 2016, p. 90). Para a autora,

os meninos de rua foram sendo tratados como a expressão emblemática da vulnerabilidade e da violência. De fato, eles são os filhos das famílias que, expostas a uma situação de carência, deslocam-se de seus núcleos domésticos, buscando mais chances para sobreviver. Trata-se de um velho problema (GREGORI, 2016, p. 90).

Citando o livro A alma encantadora das ruas (1910), de João do Rio²11, Gregori afirma que a ideia do cronista de que "a rua agasalha a miséria" traz outros sentidos implícitos. Para a autora, nesse conceito, "a desigualdade social se torna visível e problemática, bem como a noção de que no país a sociedade, em vez de tirar os miseráveis da vista, desenvolve em relação a eles não a tolerância, mas uma familiaridade desconcertante". Desse modo, eles passam a fazer parte "de nossas fronteiras simbólicas e de nossa identidade, ainda que com imenso desconforto (GREGORI, 2016, p. 90).

Brasilmar Ferreira Nunes ${ }^{212}$ reitera essa questão da desigualdade social e da herança de uma sociedade escravocrata como fatores associados diretamente na gênese

\footnotetext{
210 Maria Filomena Gregori. Professora Livre-Docente do Departamento de Antropologia, Doutora em Antropologia Social. Pesquisadora associada do Pagu - Núcleo de Estudos de Gênero (UNICAMP).

211 João Paulo E. C. S. C. Barreto (1881-1921). Cronista, contista, tradutor e romancista. Obra citada: RIO, João do. A alma encantadora das ruas. São Paulo, Cia. das Letras, 2008. "[...] a rua é um fator da vida das cidades, a rua tem alma! Em Benares ou em Amsterdão, em Londres ou Buenos Aires, sob os céus mais diversos, nos mais variados climas, a rua é a agasalhadora da miséria. Os desgraçados não se sentem de todo sem o auxílio dos deuses enquanto diante dos seus olhos uma rua abre para outra rua. A rua é o aplauso dos medíocres, dos infelizes, dos miseráveis da arte. [...]. A rua é generosa. 0 crime, o delírio, a miséria não os denuncia ela. [...]. A rua resume para o animal civilizado todo o conforto humano. Dá-lhe luz, luxo, bem-estar, comodidade e até impressões selvagens no adejar das árvores e no trinar dos pássaros".

212 Brasilmar Ferreira Nunes, falecido em 2016, foi professor titular do Departamento de Sociologia da Universidade de Brasília (UnB) e pesquisador na área de sociologia urbana.
} 
de uma infância em situação de risco. Em seu estudo sobre sociedade e infância no Brasil, o autor afirma que,

numa sociedade escravocrata, de relações sociais extremamente rígidas, com o senhor tendo controle absoluto sobre os escravos, inclusive sobre seus corpos, a estrutura social era evidente: as diferenças entre brancos e negros não deixavam dúvidas sobre o lugar social de cada um (NUNES, 2003, p. 57).

O autor cita como exemplo para se compreender as relações sociais a "sociedade patriarcal nos termos de Gilberto Freyre, em que casa-grande e senzala eram imagens complementares, mas opostas, de uma realidade cultural que caracterizaria a sociedade brasileira ao longo dos séculos" (NUNES, 2003, p. 58).

Reis e Prantes também evocam o período da escravidão, sob o ponto de vista da infância. Citando uma pesquisa de Katia Queiroz Mattoso ${ }^{213}$, os autores discutem sobre a idade em que o filho da escrava deixa de ser criança e passa ser percebido como escravo. Segundo eles, a pesquisa de Mattoso $^{214}$ revela que

as fases que correspondem à infância, à adolescência, à idade adulta e à velhice são as mesmas para a população livre e para a população escrava, mas diferem diante da função social desempenhada pelas categorias de idade. As crianças livres, independentemente da cor, poderiam ter seu prazo de ingresso na vida ativa protelado, ao passo que a criança escrava, quando atingisse os oito anos, ingressava no mundo do trabalho (REIS \& PRANTES, 1999, p. 56).

213 Katia Mytilineou de Queirós Mattoso (1931-2011). Formada em Ciência Política na Universidade de Lausanne e Doutorado na Universidade de Genebra. Primeira professora da cátedra de História do Brasil da Universidade Sorbonne, de Paris.

214 MATTOSO, Kátia de Queirós. “O filho da escrava (em torno da Lei do Ventre Livre)”. In: PRIORE, M.D. (org.). História da criança no Brasil. São Paulo. Contexto. 1991, p. 76-97. Também publicado na Revista Brasileira de História, n. 16 (1988), p. 37-55. 
Fazendo um inventário sobre as preocupações do Estado e de organizações não governamentais acerca da proteção à criança, os autores afirmam que todas as ações, desde a Constituição de 1824, além de serem "muito tímidas", ficaram apenas no "campo da formalidade da Lei". Conforme os autores, "as desigualdades se acentuaram e proliferaram de acordo com as distintas regiões onde ocorreram os diferentes ciclos econômicos no País" e "a orientação de políticas sociais somente passa a ser uma prioridade do Governo a partir dos anos 30 deste século ${ }^{215}$, quando do início da reversão do modelo de crescimento rural agrário-exportador para urbano industrial" (REIS \& PRANTES, 1999, p. 45-46).

Para Nunes, já no final do século XIX a infância começa a surgir como preocupação para o Estado, que passa a se ocupar de

crianças pobres, por meio de uma prática repressiva, via legislação própria: a criação de instituições sobretudo para o "menor infrator'". Substituía-se, assim, a categoria infância pela de "menor", com uma enormidade de leis, códigos e instituições que se sucediam, especialmente a partir da República (NUNES, B. 2003, p. 58-59).

Cabe aqui, então, um breve retrospecto para analisar esse conjunto de decretos e leis, visando à proteção e à educação de crianças no Brasil, especialmente considerando como escopo a primeira metade do século $\mathrm{XX}$, período em que se situam os textos literários que estudamos nesta tese.

De acordo com Nunes, "a infância como objeto da ação pública estatal esteve sempre presente nas decisões do Estado voltadas ao ordenamento social". Porém, ao se considerar que "o Estado brasileiro só começou a estruturar-se no século XIX", concluise "não ser muito antiga a regulação estatal sobre as crianças" (NUNES, B. 2003, p. 57). Nos dizeres do autor,

${ }^{215} \mathrm{O}$ autor se refere ao século XX. 
a estruturação do Estado é fenômeno relativamente recente entre nós, situável entre o fim do século XIX e o início do século XX, com a liberação dos escravos e a Proclamação da República, culminando com os primeiros passos para se formar um mercado livre da força de trabalho (NUNES, B. 2003, p. 104).

No entanto, algumas medidas relacionadas à infância começaram a aparecer antes mesmo da Proclamação da República, uma vez que em $1824^{216}$ já se tem o registro do "direito do cidadão à instrução primária gratuita" (NUNES, 2003, p. 112) em uma lei brasileira ${ }^{217}$. Apesar de esse direito ter sido novamente declarado na Assembleia Nacional de $1891^{218}$, de acordo com Nunes, "essas duas leis não vigoraram”, uma vez que isentavam os "extremamente pobres" e excluíam "boa parcela da sociedade" (p. 112-113) ${ }^{219}$. Também em 1891 surge o primeiro decreto regulamentando o trabalho infantil nas fábricas do Rio de Janeiro, que era prática já comum desde o século XIX e, por esse motivo, justificava uma jurisprudência específica (p. 113) 220 .

De acordo com Irma Rizzini221, "a extinção da escravatura foi um divisor de águas no que diz respeito ao debate sobre trabalho infantil; multiplicaram-se, a partir de então, iniciativas privadas e públicas", com o objetivo de preparar a criança e o adolescente para o trabalho, na indústria e na agricultura (RIZZINI, 2013, p. 376). Para a autora,

\footnotetext{
${ }^{216}$ Dois anos após a Proclamação da Independência, foi outorgada a primeira Constituição Brasileira, por D. Pedro I, em 25 de março de 1824. Entre as principais características, a constituição garantia o sistema monárquico, concentrando o poder na figura do Imperador. Os demais representantes do governo eram escolhidos pelos nobres e aristocratas - apenas os ricos podiam votar. A Igreja estava subordinada ao Estado.

217 O direito está exposto no artigo 179, parágrafo 32.

${ }^{218}$ Data da segunda Constituição, que tinha como contexto a Proclamação da República (1889). Artigo 72, parágrafo 6 (p. 112).

${ }^{219}$ De acordo com o autor, a exclusão de "boa parcela da sociedade" deve-se ao regime de trabalho escravo vigente em 1824 (p. 112-113).

220 Decreto-Lei no. 1313, assinado pelo então Presidente da República, Marechal Deodoro da Fonseca. Foram incluídos no decreto itens como "fiscalização, limite de idade, fixação da jornada de trabalho", entre outras (p. 113).

${ }^{221}$ Irma Rizzini. Mestre em Psicologia Social e Doutora em História Social pela UFRJ. Professora Associada da Faculdade de Educação da UFRJ e do Programa de Pós-Graduação em Educação-PPGE/UFRJ. Pesquisadora na área da História da Educação.
} 
o debate sobre a teoria de que o trabalho seria a solução para o "problema do menor abandonado e/ou delinquente" começava, na mesma época, a ganhar visibilidade (RIZZINI, 2013, p. 376-377).

Do mesmo modo, “o advento da República inaugura uma era de novas preocupações", uma vez que o país em crescimento "dependia de uma população preparada para impulsionar a economia nacional" (RIZZINI, 2013, p. 378). Segundo a autora,

asilos de caridade foram transformados em institutos, escolas profissionais, patronatos agrícolas. Surgem novas instituições, algumas fundadas por industriais, visando à adequação do menor às necessidades da produção artesanal e fabril, formando desde cedo a futura mão de obra da indústria (RIZZINI, 2013, p. 378-379).

Em 1902, em uma reforma do Serviço Policial Federal, pela primeira vez se percebe uma mobilização da esfera estatal acerca de "crianças infratoras" - que recebem, na época, a denominação "menores viciosos". Nessa ocasião, segundo Nunes, foi proposta a criação de "colônias correcionais" visando à "reabilitação, pelo trabalho e instrução", dessas crianças (NUNES, 2003, p. 113-114). Para o autor,

a reforma indicava certa preocupação em amenizar riscos de uma reprodução social via mendicidade e criminalidade. Entretanto, não havia certeza sobre a denominação "menores viciosos". Crê-se que filhos de ex-escravos, portanto negros e pobres, estariam mais enquadrados nessa categoria. De qualquer forma, o tratamento do menor pela estrutura estatal existente dá sinais de se tratar de "caso de polícia”, postura comum ao longo do século (NUNES, 2003, p. 114). 
Quatro anos mais tarde, em 1906, "foi apresentado e (ao mesmo tempo) rejeitado na Câmara Federal o primeiro projeto para criação de um Juizado de Menores" (NUNES, 2003, p. 114). De acordo com o autor,

vislumbrava-se ser necessária uma esfera no Judiciário para lidar com o problema da "infância desvalida", como era tratada. A preocupação com o menor pobre - ou transgressor, como se traduzia e se traduz - e a natureza do tratamento a ele imposto, observada desde fins do século XIX, repetir-se-ão pelo século XX (NUNES, 2003, p. 114-115).

Em 1921, definiu-se juridicamente o termo "menor abandonado"222, como aquele "sem moradia certa, sem meios de subsistência, órfão, ou cujos responsáveis eram julgados incapazes de sua guarda”. Segundo Nunes, "a lei marcou a entrada direta do Judiciário no tratamento da criança pobre, meninos não absorvidos pelo mercado de trabalho industrial ou de prestação de serviços". Para o autor, a legislação "induzia as famílias pobres a controlar com maior atenção seus filhos; caso contrário, estariam sujeitas a perdê-los (NUNES, 2003, p. 115).

De acordo com Rizzini, ainda nos anos 1920,

a falta de braços para a agricultura levou à criação de colônias agrícolas no Brasil, respaldadas pela ideia de que "a criança é o melhor imigrante". Em todo o Brasil, por iniciativa do Departamento Nacional de Povoamento, funcionaram vinte patronatos agrícolas, colônias que albergavam e atendiam crianças recolhidas nas ruas, visando exatamente à formação do trabalhador nacional (RIZZINI, 2013, p. 379).

${ }^{222}$ Lei no. 4242 que modificava o Código Civil de 1917. 
Dessa forma, os patronatos recebiam o "limbo da sociedade", isto é, "garotos que perambulavam pela cidade". Para a autora essa manobra configurava "uma política voltada para o ordenamento do espaço urbano e de sua população, por meio do afastamento dos indivíduos indesejáveis para transformá-los nos futuros trabalhadores da nação" (RIZZINI, 2013, p. 379-380)223. Porém o fato é que não se esperava que a criança crescesse para ocupar seu lugar no mercado de trabalho:

\begin{abstract}
A história desses institutos mostra que o preparo do jovem tinha mais um sentido político-ideológico do que de qualificação para o trabalho, pois o mercado (tanto industrial como agrícola) pedia grandes contingentes de trabalhadores baratos e não qualificados, porém dóceis, facilmente adaptáveis ao trabalho (RIZZINI, 2013, p. 380).
\end{abstract}

E a criança de rua - pobre, órfã ou desvalida - preenchia todos os requisitos para desempenhar esse papel.

Em 1923 criou-se o Juizado de Menores do então Distrito Federal, no Rio de Janeiro, consolidando-se "a primeira intervenção direta e sistemática do Estado na questão da infância pobre no Brasil", culminando, em 1927, com o primeiro Código de Menores que definiu leis de assistência e proteção a crianças ${ }^{224}$. De acordo com Nunes, o termo "menores" passa a ser utilizado no vocabulário corrente como uma "categoria classificatória da infância pobre" (NUNES, 2003, p. 116).

A Constituição de 1934 trouxe algumas alterações no que se refere à regulamentação do trabalho infantil, limitando-o a maiores de catorze anos ${ }^{225}$, e proibindo o trabalho noturno a menores de dezesseis anos. A Lei apresentou ainda como novidade a normatização para empresas de médio e grande porte, responsabilizandoas "na alfabetização dos filhos de seus empregados". Questionada, essa prática não

${ }^{223}$ De acordo com a autora, os patronatos foram extintos uma década depois, por terem se tornado "centros indesejáveis, verdadeiros depósitos de menores" (RIZZINI, 2013, p. 380).

${ }^{224}$ Decreto no. 17.943, de 1927, promulgado pelo Poder Judiciário (NUNES, p. 116).

225 A Lei no. 1801 de 1911, promulgada na Assembleia Nacional já definia a idade mínima de 14 anos para o trabalho infantil. Foram estabelecidas ainda algumas condições para se admitir o menor, como apresentação de atestado médico, escolarização mínima, vacinação e jornada de trabalho de seis horas (NUNES, 2013, p. 115). 
vigorou, ficando posteriormente a cargo do Estado a educação das crianças, eximindose os empresários desse "custo social" (NUNES, 2003, p. 116).

A quarta Constituição Brasileira226, ainda inserida no contexto da "Era Vargas”, retomou “a obrigatoriedade dos ensinos primário e pré-vocacional gratuitos para crianças pobres". Para Nunes, "especialmente no pré-vocacional, novidade na Constituição de 1937, evidenciou-se a preocupação do Estado de incorporar no mercado de trabalho a infância pobre e delinquente, crescente nas grandes capitais" (NUNES, 2003, p. 117) e a parceria das indústrias e sindicatos na normatização da educação profissional para aprendizes.

Em 1940 foi criado o Serviço de Assistente ao Menor (SAM), subordinado ao Ministério da Justiça, apontando seus objetivos para o combate e prevenção à criminalidade infanto-juvenil ${ }^{227}$. A partir de então, "a infância passou a ser tratada como problema nacional, não mais fenômeno regional ou específico da capital federal" (NUNES, 2003, p. 117). Nesse contexto, em 1942 surge a LBA - Legião Brasileira de Assistência, com o propósito de oferecer amparo a filhos dos integrantes da Força Expedicionária Brasileira que participariam da Segunda Guerra. "Tradicionalmente dirigida por esposas de presidentes da República em exercício", conforme Nunes, o programa "evoluiu para centro de assistência a mães grávidas e a suas crianças em primeira infância (zero a seis anos)" e a função assistencialista prevaleceu durante toda a sua existência (p. 117-118) 228 .

Em 1942, as Escolas de Aprendizes e Artífices passaram a funcionar como Escolas Industriais e Técnicas, oferecendo formação profissional em nível equivalente ao do secundário. A partir desse ano, iniciou-se, formalmente, o "processo de vinculação do ensino industrial à estrutura do ensino do país, uma vez que os alunos formados nos

\footnotetext{
${ }^{226}$ A Constituição brasileira de 1937 foi a primeira a tratar especificamente de ensino técnico, profissional e industrial. No Art. 129 lê-se: "O ensino pré-vocacional e profissional destinado às classes menos favorecidas é, em matéria de educação, o primeiro dever do Estado. Cumpre-lhe dar execução a esse dever, fundando institutos de ensino profissional e subsidiando os de iniciativa dos Estados, dos Municípios e dos indivíduos ou associações particulares e profissionais. É dever das indústrias e dos sindicatos econômicos criar, na esfera de sua especialidade, escolas de aprendizes, destinadas aos filhos de seus operários ou de seus associados. A lei regulará o cumprimento desse dever e os poderes que caberão ao Estado sobre essas escolas, bem como os auxílios, facilidades e subsídios a lhes serem concedidos pelo poder público" (portal.mec.gov.br).

227 De acordo com Nunes, o SAM derivou-se da Casa do Jornaleiro, programa criado dois anos antes para atender menores carentes, que teria sido "gestado lentamente" a partir da década de 20 (Nunes, p. 117). ${ }^{228}$ Após denúncias de desvio de verbas durante o governo Collor (1990-1992), o programa foi extinto em 1995, pelo então Presidente da República Fernando Henrique Cardoso.
} 
cursos técnicos ficavam autorizados a ingressar no ensino superior em área equivalente à da sua formação" 229 .

No ano seguinte, o trabalho infantil voltaria a ser tema das leis trabalhistas brasileiras ${ }^{230}$, estabelecendo-se o "menor aprendiz" como aquele com idade entre doze e dezoito anos. De acordo com o decreto, o trabalho passa a ser proibido a menores de doze anos e o trabalho noturno, a menores de dezoito anos de idade 231 . Três anos mais tarde, em 1946, juntamente com a instauração da nova Constituição, é criado o SENAI Serviço Nacional de Aprendizagem Industrial, buscando-se regulamentar o trabalho do aprendiz 232 .

A partir da segunda metade do século XX, outras ações bastante significativas foram implementadas por meio de estatutos, leis e decretos, culminando com a regulamentação do ECA - Estatuto da Criança e do Adolescente, em julho de 1990, documento que visa à proteção integral da criança e do adolescente ${ }^{233}$, ratificando a Declaração Universal dos Direitos da Criança, promulgada pela Assembleia Nacional das Nações Unidas, em 1989. Uma das novidades do documento foi substituir a terminologia "menor" por "criança” e "adolescente”, uma vez que o termo "menor" adquiriu, com o decorrer do tempo, uma ideia de diminuição e desprestígio, além de uma associação direta à delinquência e ao crime.

No que se refere aos atos ilícitos cometidos por menores de idade, o Estatuto prevê "medidas socioeducativas" em vez de "punitivas", e, em casos de abusos contra a criança ou o adolescente, a instauração de um Conselho Tutelar, encarregado de zelar pelo cumprimento dos seus direitos. De acordo com Nunes,

o Estatuto reserva tratamento especial à regulamentação de atos infracionais praticados por menores [...]. O menor está protegido pela lei até os 18 anos, e quaisquer punições que venha a sofrer estão regulamentadas pelo Estado (NUNES, 2013, p. 125).

\footnotetext{
${ }^{229}$ Decreto no 4.127, de 25 de fevereiro de 1942. Ministério da Educação e da Cultura (portal.mec.gov.br). 230 Decreto Lei 5452/43, Consolidação das Leis do Trabalho, 1943.

231 Artigos 80, 403 e 404. (Nunes, p. 118).

232 De acordo com Nunes (2013, p. 118), "o Senai foi exemplo para o Serviço Social da Indústria (Sesi), o Serviço Social do Comércio (Sesc) e o Serviço Nacional de Aprendizado Comercial (Senac), instituições oriundas da iniciativa privada, responsáveis por um importante segmento da política social da Era Vargas".

233 De acordo com o ECA, é considerada criança a pessoa com idade inferior a doze anos, e adolescente, de doze a dezoito.
} 
Do mesmo modo com que aborda a questão do menor infrator, o Estatuto regulamenta as ações abusivas e agressivas cometidas contra a criança ou o adolescente, seja ele infrator ou não. Para Nunes, "um dos mais importantes avanços do Estatuto refere-se a crimes e a infrações contra criança e adolescente e à fiscalização do cumprimento da lei". Desse modo,

em contraposição à completa omissão do Código e da Política do Menor a esse respeito, o Estatuto estabelece penas para abuso do pátrio poder por autoridades e por responsáveis de crianças e adolescentes, bem como prevê participação ativa da comunidade, que por meio de mecanismos de defesa e proteção de interesses coletivos pode levar autoridades ao banco dos réus (NUNES, 2013, p. 129).

Encerrando este percurso histórico, enfatizamos a dualidade com que Nunes conclui seus estudos, afirmando que "o contexto brasileiro tem dois universos distintos": de um lado, "pobres e excluídos"; de outro, "classe média e ricos", contexto que engloba também a questão da infância. Para o autor, "nas relações entre infância e sociedade estão impregnadas diferentes concepções de cidadania, distintas práticas sociais" (2013, p. 156). Em suas palavras,

é na relação entre as funções de representação (sociedade) e as de regulação (Estado) que se estruturam as dinâmicas sociais dirigidas à infância (NUNES, 2013, p. 156).

No Brasil, o olhar para a criança, especialmente para a criança desamparada, não é exclusividade de pesquisas acadêmicas, como já citava Gregori234 e aqui reafirma Nunes.

${ }^{234}$ A autora cita a crônica de João do Rio, em que o autor aponta o problema dos moradores de rua. 
No capítulo de seu livro intitulado "O imaginário social sobre a infância no Brasil"235, o autor chama a atenção para diferentes formas de representação sobre a criança e o adolescente brasileiro, especialmente por meio da arte. $\mathrm{O}$ autor cita as artes plásticas, o cinema e a literatura como suportes que "veiculam símbolos da realidade infantil, representando e formando ao mesmo tempo um imaginário social" (NUNES, 2013, p. 67) desse universo chamado infância.

Considerando as artes plásticas no período colonial, o autor destaca a produção de Debret ${ }^{236}$, “como a que mais se ocupou de nosso cotidiano". Revela ainda a figuração da criança em sua "dupla dimensão: de um lado o menino branco bem vestido, que frequentemente fica sob os olhares de uma escrava a vigiá-lo; de outro lado o menino negro de pouca roupa, em clara alusão ao clima dos trópicos, gozando de liberdade plena para brincar" (p. 67-68). Para o autor, "a paisagem de Debret fornece características precisas de relacionamentos e hábitos dos quais se deduzem mecanismos de socialização" (p.68-69).

Referindo-se ao cinema nacional e ao protagonismo infantil, o autor cita como exemplos os filmes Rio 40 graus (1955), de Nelson Pereira dos Santos, e Pixote (1980), de Hector Babenco, definindo-os como "obras lapidares na denúncia de questões estruturais" relativas à infância, mostrando "crianças abandonadas no 'inferno' urbano, jogadas numa rotina de transgressões contínuas, em que a lei as coloca na marginalidade definitiva" (p. 74) 237.

Quanto à representação da infância na literatura, entre as obras citadas por Nunes, que incluem Vidas secas (Graciliano Ramos, 1937) e Menino de engenho (José Lins do Rego, 1932), o autor faz uma breve porém incisiva menção a Capitães da Areia, romance que analisaremos em seguida. Para o autor, nessa obra

Jorge Amado olha o mundo do ponto de vista das crianças excluídas, construtoras de uma realidade com códigos de comportamento específicos. Mesmo reproduzindo comportamentos adultos, as crianças constroem um universo particular, cujos valores são determinados por uma lógica a partir delas (NUNES, 2013, p. 72).

235 NUNES, 2013, p. 57-94.

236 Jean-Baptiste Debret (1768-1848). Pintor francês.

237 Central do Brasil (1998) e Cidade de Deus (2002) são filmes mais recentes que poderiam fazer parte deste rol de obras cinematográficas que abordam a questão da infância. 
Escrito nos anos 1930, em uma época em que as discussões acerca das "crianças em situação de risco", das "crianças de rua", do "menor abandonado" ou do "menor infrator" estavam apenas começando, como pudemos demonstrar neste preâmbulo, em Capitães da Areia Jorge Amado

lança o debate sobre um futuro fenômeno nas grandes cidades brasileiras: o menino de rua, o trabalho infantil, o menor transgressor, causador de espanto e indignação às famílias de classe média urbanas. Num universo dominado por crianças que dia a dia têm de garantir a sobrevivência, os códigos repetem, no essencial, códigos maiores da sociedade, em aparente simbiose entre o mundo da criança e o mundo do adulto (NUNES, 2013, p. 72-73).

Nunes conclui, afirmando que "a evolução dessa realidade" demonstra que não somente o fenômeno dos meninos de rua generaliza-se "como assume níveis de problema social amplo sob efeitos da miséria, da violência e do desamparo a que estão sujeitos os 'capitães da areia' no fim do século XX" (NUNES, 2013, p. 73). 


\subsection{0 menino grapiúna, um contador de histórias}

Em outubro de 1996, então aos 84 anos de idade, Jorge Amado concedeu uma longa entrevista para o terceiro volume da coleção Cadernos de Literatura Brasileira, do Instituto Moreira Salles, no qual seria o autor homenageado. Nesse colóquio, por meio de mais de uma centena de perguntas e respostas, o percurso do escritor baiano no cenário da nossa literatura, inaugurado ainda quando muito jovem, com a publicação de O país do carnaval (1931), foi amplamente revisitado. Ao final do encontro, com a modéstia que lhe era característica, Jorge Amado define-se da seguinte maneira:

Eu sou um contador de histórias, não sou outra coisa. Eu venho e conto a minha história. Aquilo que eu sei e como sei. Isso é o que importa (IMS, 1997, p. 57).

Infelizmente, o escritor baiano - que se tornou ao longo do século XX um dos maiores expoentes da literatura brasileira moderna ${ }^{238}$ - não teria muito mais tempo para contar suas histórias ${ }^{239}$. Após a veiculação da entrevista, em março de 1997, apenas um livro de sua autoria ainda seria publicado, 0 milagre dos pássaros, e, assim mesmo, embora inédito ao público, não se tratava de seu romance derradeiro, uma vez que havia sido escrito quase duas décadas antes ${ }^{240}$.

\footnotetext{
238 Suas obras alcançaram no final do século XX a marca de vinte milhões de cópias vendidas somente no Brasil, além de dezenas de traduções por todo o mundo. Foram ao todo 32 romances, totalizando - até agosto de 2001 - 20,7 milhões de cópias vendidas (números que não incluem obras em parceria). Seu romance mais vendido é Capitães da Areia, com 4,3 milhões de cópias, de acordo com reportagem veiculada pela Folha de S. Paulo, por ocasião de sua morte (http://www1.folha.uol.com.br/folha/ ilustrada/ult90u16304.shtml). Seus romances foram traduzidos para 48 idiomas, totalizando 52 diferentes nações, de acordo com a Fundação Casa de Jorge Amado APUD Cadernos, p. 5.

239 Jorge Amado viria a falecer cinco anos depois, em agosto de 2001, quatro dias antes de completar 89 anos.

240 De acordo com informações da Fundação Casa de Jorge Amado, "O milagre dos pássaros foi escrito em 1979, por encomenda, para ser distribuído como presente de fim de ano de uma instituição financeira". Porém a primeira edição comercial seria publicada apenas em 1997. Assim, o último romance escrito por Jorge Amado teria sido A descoberta da América pelos turcos (1992). Ainda houve duas publicações póstumas, Hora da guerra (2008), uma coleção de crônicas escritas entre os anos 1942 e 1945, e Toda a saudade do mundo (2012), uma coletânea de cartas trocadas entre Jorge Amado e Zelia Gattai, por ocasião de seu exílio em Paris, em 1948.
} 
A carreira do romancista, no entanto, prenunciou-se bem cedo, quando ele ainda era um "menino grapiúna"241. Enclaustrado em um colégio interno jesuíta em Salvador - que ele considerava uma verdadeira "prisão" -, aos onze anos Jorge Amado já revelaria sua vocação para escrever. O episódio, narrado em seu romance autobiográfico, O menino grapiúna (1981), revela como o padre Cabral, que substituía com novidades metodológicas o então efetivo professor de português, descobriria o talento do jovem escritor por meio de uma redação de sua autoria, intitulada "O mar". A cena está contida no último capítulo do livro:

O mar de Ilhéus foi o tema de minha descrição. Padre Cabral levara os deveres para corrigir em sua cela. Na aula seguinte, entre risonho e solene, anunciou a existência de uma vocação autêntica de escritor naquela sala de aula. Pediu que escutassem com atenção o dever que ia ler. Tinha certeza, afirmou, que o autor daquela página seria no futuro um escritor conhecido. Não regateou elogios. Eu acabara de completar onze anos (AMADO, 1982, p. 118).

Padre Cabral, esse religioso português de sobrenome homônimo ao do descobridor do Brasil, não seria responsável pela descoberta de uma nova terra, mas de um "terreno fértil”, que certamente frutificaria, se cultivado. Assim, não se contentando em tornar o jovem prodígio conhecido e respeitado no internato ("passei a ser uma personalidade, segundo os cânones do colégio"), o padre nada ortodoxo apresentou ao menino o mundo da literatura infantil e juvenil, que o estudante até então desconhecia, emprestando-lhe para leitura, entre outras obras, As viagens de Gulliver, "clássicos portugueses e traduções de ficcionistas franceses e ingleses", como Charles Dickens, por exemplo, por quem o autor baiano até o fim da vida demonstrava profunda reverência (AMAD0, 1982, p. 118-119).

Ainda com relação a esse episódio, o autor credita ao mar de Ilhéus sua salvação, e à descoberta das Viagens de Gulliver, os "caminhos da libertação", que o conduziriam, anos depois, para fora do internato. Atribui, também, ao erudito e

\footnotetext{
241 "Designação dada pelos sertanejos aos habitantes do litoral" (Houaiss eletrônico). Jorge Amado atribui a expressão "menino grapiúna" a si mesmo em romance autobiográfico homônimo ( $O$ menino grapiúna, 1981).
} 
"herético" Padre Cabral todos os méritos por tê-lo iniciado nem tanto na arte da escrita, que já lhe pertencia, mas no "amor pelos livros", que nele ainda hibernava (p. 119). Nas palavras do narrador de $O$ menino grapiúna,

no colégio dos jesuítas, pela mão herética do padre Cabral, encontrei nas "Viagens de Gulliver" os caminhos da libertação, os livros abriramme as portas da cadeia. [...] Dos estreitos limites do internato, fui salvo pelo mar - o mar de Ilhéus, a praia do Pontal, as marés mansas e a tempestade. [...] Em lugar de nos fazer analisar "Os Lusíadas", tentando descobrir o sujeito oculto e dividir as orações, reduzindo o poema a complicado texto para as questões gramaticais, fazendo-nos odiar Camões, o padre Cabral, para seu deleite e nosso encantamento, declamava para os alunos episódios da epopeia. [...] As aulas de português adquiriram outra dimensão. [...] Recordo com carinho a figura do jesuíta português erudito e amável. Menos por me haver anunciado escritor, sobretudo por me haver dado o amor dos livros, por me haver revelado o mundo da criação (AMADO, 1982, p. 103-119).

Além desse relato sobre a descoberta de sua vocação para a escrita, é possível depreender de outras passagens narradas ou descritas no livro interessantes conexões entre as experiências do menino e o substrato utilizado para compor a criação literária do escritor Jorge Amado. 0 próprio autor revela, tanto na citada entrevista como no romance autobiográfico, o caminho traçado entre suas memórias e as experiências vividas, transportadas depois para a sua ficção.

Desse modo, ao ser questionado, durante a entrevista, sobre a relação entre a ideia de insubordinação diante da morte em Quincas Berro d'Água ${ }^{242}$, e um "certo grau" de autobiografia nesse romance, o autor afirma:

[...] eu não diria que Quincas tenha algo de autobiográfico, embora, como em tudo o que escrevo, haja no livro alguma influência do que eu vivi e conheci (IMS, 1997, p. 49).

${ }^{242}$ A morte e a morte de Quincas Berro d'Água (1961). 
Também quando indagado sobre seu método de trabalho para compor um romance, o autor confidencia: "Eu nunca tomo notas. Como escrevo sobre aquilo que vivi, aquilo que conheço, uso muito minha memória" (IMS, 1997, p. 45).

Em O menino grapiúna, o escritor-narrador confessa compor seus personagens de romances com a "soma de figuras" que a ele se impuseram durante a vida, que fizeram parte "de sua experiência vital". Dessa maneira, revela ser o tio paterno, Álvaro Amado, sua principal fonte de inspiração na criação de grande parte de seus coronéis:

Os personagens das obras de ficção resultam da soma de figuras que se impuseram ao autor, que fazem parte de sua experiência vital. Assim são os coronéis do cacau nos livros onde trato de região grapiúna, nos quais tentei recriar a saga da conquista da terra e as etapas de construção de uma cultura própria. Creio que em todos esses coronéis há um pouco do meu tio Álvaro Amado (AMADO, 1982, p. 71-72).

Assim, do mesmo modo que José Lins do Rego usa suas memórias para elaborar as narrativas que compõem o "ciclo da cana-de-açúcar"243, as reminiscências do menino grapiúna também vão criando o substrato para que o escritor Jorge Amado construa, mais tarde, seus personagens e muitas das situações por eles vividas na ficção, permeando suas narrativas com fragmentos de realidade da sua própria experiência de vida.

Um exemplo é o contato do autor com a varíola, moléstia geralmente mortal no início do século XX, narrado nos primeiros capítulos de $O$ menino grapiúna ${ }^{244}$. No livro, é relatado um episódio ocorrido no ano de 1914, quando a família do escritor baiano precisou se refugiar no lazareto, local "habitualmente reservado a leprosos e bexigosos"245. Para ele, o fato de ter "convivido" com o vírus nessa época tornou-o imune à doença:

\footnotetext{
243 Ver Capítulo 3, "Verdes anos": reminiscências de um menino de engenho.

${ }^{244}$ Capítulos 2 e 3 (AMADO, 1982, p. 15-25).

245 Narrado no segundo capítulo do livro, o episódio relata uma enchente do rio Cachoeira, em 1914, que desalojou a família, obrigando-os a seguir viagem ao povoado de Ferradas, e a refugiar-se no lazareto, único local disponível (AMADO, 1982, p. 18).
} 
Quem sabe devo a essa amedrontadora hospedaria de minha primeira infância o fato de ter permanecido imune à varíola até hoje [...]. Todo mundo de braço inchado, febril, sentindo-se mal. Permaneci impávido, a subir pelas árvores, a correr na praia. A bexiga fazia parte de meu sangue (AMADO, 1982, p. 18-19).

A varíola - ou bexiga, como é geralmente tratada em seus romances - é tema presente, por exemplo, tanto em Capitães da Areia (1937) como em Tereza Batista cansada de guerra (1972) ${ }^{246}$. Em O menino grapiúna, o autor detalha a doença, seus sintomas, suas marcas, o caminho muitas vezes sem volta dos enfermos ao lazareto, cenas registradas por seus olhos de criança:

Por milagre um bexigoso se curava, regressava com as marcas no rosto e nas mãos. Macabra visão de infância a me fazer estremecer até hoje: os bexigosos, metidos em sacos de aniagem, sendo levados para o lazareto, carregados pelos miraculados [...]. Caminhando lado a lado com a morte, incorporado ao reduzido grupo de familiares, acompanhei de longe o transporte de um colega de escola primária até que o carregador, com o saco às costas, desapareceu no caminho, nos limites da cidade. A bexiga e os bexigosos povoam meus livros, vão comigo pela vida afora (AMADO, 1982, p. 24-25).

Desse modo, ao mesmo tempo que lhe estremecem a infância com a "macabra visão", os fatos funestos alimentam o repertório do romancista.

A bexiga, porém, é apenas uma das "visões de morte" que se manifestariam ao menino grapiúna durante esses primeiros anos de vida. Contatos com jagunços, pessoas feridas a bala, tocaias, cangaço, doença e miséria, várias são as situações vividas e relatadas pelo autor, em seu romance autobiográfico. E essas peripécias do menino,

\footnotetext{
${ }^{246}$ Em Capitães da Areia, a descrição da doença é feita no capítulo "Alastrim", nome também dado à "bexiga branca", uma forma menos grave da varíola, mas também mortal. Dois meninos do bando adoecem; um morre, outro se cura. A doença também é responsável pela orfandade de Dora. Já em Tereza Batista, a protagonista ajuda a combater uma epidemia de varíola, na cidade de Buquim, ajudando os doentes da "bexiga negra".
} 
embora em outra escala, nos remetem, em algumas situações, ao personagem Carlinhos, de Menino de Engenho.

De fato, há algo de "menino de engenho" no menino grapiúna. Um exemplo é a liberdade com que ambos foram criados, cerceada ao final da infância com a partida para o colégio interno. Os excertos que seguem - o primeiro, extraído da obra de estreia de José Lins do Rego; o segundo, do romance autobiográfico de Jorge Amado - nos revelam a semelhança do contexto:

No dia seguinte tomaria o trem para o colégio. [...] Acordei com os pássaros cantando no gameleiro. Tocavam dobrados ao meu bota-fora. E uma saudade antecipada do engenho me pegou em cima da cama. Vieram-me acordar. Há tempo que estava de olhos abertos na companhia de meus pensamentos. Uma outra vida ia começar para mim.

“Colégio amansa menino!". Em mim havia muita coisa precisando de freios e de chibata. [...] Agora o colégio iria consertar o desmantelo desta alma descida demais para a terra. [...] Cortava-me a alma a saudade do meu engenho (REGO, 2013, 138-140).

Para o menino grapiúna - arrancado da liberdade das ruas e do campo, das plantações e dos animais, dos coqueirais e dos povoados recémsurgidos -, o internato no colégio dos jesuítas foi o encarceramento, a tentativa de domá-lo, de reduzi-lo, de obrigá-lo a pensar pela cabeça dos outros. A intenção do pai era apenas educá-lo no melhor colégio, o de maior renome. Não se dava conta de como violentava o filho (AMADO, 1982, p. 101-102).

"Amansar" e "domar" são os termos usados, respectivamente, pelos narradores de Menino de engenho e $O$ menino grapiúna. Como se a liberdade infantil da mesma forma que cavalos selvagens - precisasse agora de "freios e chibata". Para ambos os meninos, a ida ao colégio marca o fim de uma época, o fim da liberdade, o começo de uma “outra vida”. É a despedida da infância. 
Outro fato coincidente no relato dos dois narradores é a precocidade com que ambos foram expostos à sexualidade. Carlinhos fora iniciado nos caminhos para a escola, na companhia de Zé Guedes, moleque do engenho que, além de ministrar aulas teóricas e práticas sobre sexo, foi responsável por lhe apresentar as casas das prostitutas, que muito em breve fariam parte da sua vida. Já o menino grapiúna ampliava "seu universo" nas viagens a Pirangi, na companhia de trabalhadores e jagunços, em particular Argemiro e Honório:

0 menino teve que esperar alguns anos para conhecer e frequentar as salas de jogatina nos fundos do bar [...] Mas as casas de mulher-dama, essas lhe foram familiares desde a meninice [...]. Enquanto esperava, o menino ia de mão em mão, de ternura em ternura, de afago em afago, de rapariga em rapariga, cada qual mais maternal. [...]. Em minha infância e adolescência, as casas de mulheres-da-vida, em vilas e povoados, em pequenas cidades, nas ladeiras da Bahia, significaram calor, agasalho e alegria. De certa maneira, nelas cresci e me eduquei, parte fundamental de minhas universidades (AMADO, 1982, p. 51-56).

E do mesmo modo que a negra Luísa iniciara Carlinhos dentro da sua própria casa nos prazeres do sexo e da masturbação, para o menino grapiúna a tarefa ficou por conta da "solteirona" Marocas, e não, como se haveria de supor, dos prostíbulos que frequentava:

$\mathrm{Na}$ roça, na hora do banho, Marocas, solteirona devota e carente, examinava ansiosa o sexo do menino, nele encostava o rosto, suspirando - foi quem primeiro o masturbou. Nas casas de rapariga, quando Argemiro ou Honório entregava o menino aos cuidados das mulheres, nenhuma delas, jamais, teve gesto ou anelo que não fosse puro e maternal (AMADO, 1982, p. 56-57). 
Assim, diferentemente do que ocorrera com Carlinhos em Menino de Engenho, que experimentou precocemente os prazeres da carne com a prostituta Zefa Cajá, o espírito "maternal" com que o menino grapiúna era tratado nos prostíbulos transformou-se em respeito e consideração pelas mulheres da vida, que, "despidas de todos os direitos, renegadas por todas as sociedades, perseguidas, enganadas, degradadas, possuíam imensas reservas de ternura, incomensurável capacidade de amor" (AMAD0, 1982, p. 57). E dessa forma povoaram muitos dos romances de Jorge Amado, não apenas como meras figurantes, mas muitas vezes, como personagens da maior importância.

De fato, ao nos aproximarmos da obra de Jorge Amado, é possível perceber como muitas vezes o autor oferece o protagonismo de seus romances aos "vilões da sociedade", apresentando a luta de classes, de raças e ideologias muitas vezes pelo lado do "mais fraco". Para o crítico literário Fábio Lucas247, “a maior contribuição de Jorge Amado ao debate sobre as relações raciais do Brasil consiste no registro que perpetrou da cultura mestiça, com agregação positiva ao nosso processo histórico" (LUCAS, 1997, p. 110). Ainda, para Lucas,

na visão crítica do Brasil, Jorge Amado trabalha com a contraposição histórica do branco perante o preto e oferece, como resposta positiva, o imenso estuário da miscigenação. E mitiga os diferentes jogos opositivos [...] com a força do progresso, a astúcia do amor, a alegria de viver, a ruptura das regras e o sincretismo religioso (LUCAS, 1997, p. 108).

Ainda de acordo com Lucas, “dentro de seu engajamento político, Jorge Amado não omite a dignidade do negro e a força da contribuição africana ao projeto de formação do brasileiro" (1997, p. 110). Para o autor,

${ }^{247}$ Fábio Lucas (1931). Escritor e crítico literário brasileiro. 
Jorge Amado retoma o projeto de identidade nacional, que vinha sendo elaborado ao longo de nossa história. E o faz incorporando as personagens que Roger Bastide, em prefácio à novela $A$ morte e a morte de Quincas Berro d'água (1961), chamou de os "vagabundos da liberdade", assim como a camada de negros e mestiços que emprestam novo colorido à arte de viver" (LUCAS, 1997, p. 110).

Em $O$ menino grapiúna, o autor relata sua experiência com o que ele chama de "vagabundos". Desse contato se criariam figuras recorrentes em suas narrativas, como os marinheiros, os gatunos, os capoeiristas, os jogadores, as mães-de-santo, os aventureiros, as mulheres da vida, os jagunços, os "Capitães da Areia":

Os vagabundos ainda demorariam a fazer parte de meu universo, do meu cotidiano. Com eles comecei a tratar quando, aos treze anos, fugi do internato dos jesuítas e atravessei o sertão para chegar a Sergipe, à casa de meu avô. Depois fiz-me amigo de tantos e tantos na minha livre adolescência na cidade de Salvador da Bahia de Todos os Santos. Amigo dos vagabundos, dos mestres de saveiro, dos feirantes, dos capoeiristas, do povo dos mercados e dos candomblés. Mais que isso, fui um deles (AMADO, 1982, p. 65-66).

Desse modo, a proximidade do então jovem escritor com a "escória" da sociedade trouxe-lhe substrato para que ele desenvolvesse importante contribuição para a literatura que então surgia, nos anos 1930.

De acordo com Candido \& Castello,

a importância de Jorge Amado veio do caráter seco, participante e todavia lírico dos seus primeiros livros, que descrevem a miséria e a opressão do trabalhador rural e das classes populares. [...] Um dos traços característicos da sua maturidade foi a mistura de realismo e romantismo, de poesia e documento, voltando-se para os pobres, para a humanidade da gente de cor da sua terra, que apresenta com uma simpatia calorosa, um vivo senso do pitoresco, e, sempre, um imperativo de justiça social sobrepairando a narrativa (CANDIDO \& CASTELLO, 1968, p. 277). 
Assim, ao mesmo tempo que sua experiência de vida o aproximou do "trabalhador rural e das classes populares", afastou-o dos "heróis" e líderes, tornando sua literatura sempre mais voltada "para a humanidade da gente de cor da sua terra":

Na literatura e na vida, sinto-me cada vez mais distante dos líderes e dos heróis, mais perto daqueles que todos os regimes e todas as sociedades desprezam, repelem e condenam. Os líderes e os heróis são vazios, tolos, prepotentes, odiosos e maléficos. Mentem quando se dizem intérpretes do povo e pretendem falar em seu nome [...]. 0 humanismo nasce daqueles que não possuem carisma e não detêm qualquer parcela de poder. Se pensarmos em Pasteur e em Chaplin, como admirar e estimar Napoleão? (AMADO, 1982, p. 58-62).

É a partir desse ponto de vista, do ser socialmente excluído, da infância roubada dos meninos de rua, que se constrói a narrativa que analisaremos a seguir: Capitães da Areia, sexto romance publicado pelo autor, após o sucesso de público e crítica de seus primeiros livros, especialmente O país do carnaval (1931), Cacau (1933) e Suor (1934) 248 .

Escrito durante uma viagem pelas Américas ${ }^{249}$, Capitães da Areia traz uma temática que, quase oitenta anos depois, continua atual e em evidência, não só na Bahia nem no Brasil, mas em todo o mundo: a situação dos menores abandonados, que muitas vezes são abduzidos pela criminalidade e passam a viver de pequenos furtos ou mesmo de crimes maiores, para sobreviver ${ }^{250}$.

\footnotetext{
${ }^{248}$ Na ordem de publicação: O país do carnaval (1931), Cacau (1933), Suor (1934), Jubiabá (1935), Mar Morto (1936), Capitães da Areia (1937).

${ }^{249}$ De acordo com informações da Casa Fundação Jorge Amado, o romance teria sido escrito "em Estância, Sergipe, em março de 1937, e concluído em junho, a bordo do navio Rakuyo Maru, no Pacífico, às costas da América do Sul, rumo ao México". Foi lançado em 1a edição pela Livraria José Olympio Editora, Rio de Janeiro, em setembro de 1937. Considerado um livro de apologia ao comunismo, o romance foi banido e incinerado em praça pública. Uma reportagem publicada no Jornal do Estado da Bahia, de 17 de dezembro de 1937, explica o motivo da queima de livros, com a manchete: "Incinerados vários livros considerados propagandistas do credo vermelho" e o subtítulo: "Os livros de Jorge Amado e José Lins do Rego foram os mais atingidos". De acordo com o jornal, o romance Capitães da Areia foi o mais visado, com 808 unidades apreendidas e incineradas.

${ }^{250}$ Situação que vem sendo amplamente discutida no cenário político atual, inclusive no que se refere à diminuição da maioridade penal no Brasil.
} 
Para Milton Hatoum²51, em posfácio à 2ª edição do livro (2008),

é surpreendente a atualidade dos temas de Capitães da Areia. 0 assunto e as questões sociais que o livro explora em profundidade são, em larga medida, os mesmos da "cidade da Bahia" e de muitas outras cidades, do Brasil e da América Latina. Lido hoje, este romance ainda comove e faz pensar nas crianças desvalidas, nas crianças de rua, nas crianças abandonadas, quase todas órfãs de pai e mãe, filhos da miséria e do abandono. Atiradas à marginalidade, elas roubam e cometem outros delitos para sobreviver. Detidas, são submetidas à humilhação, ao castigo, à tortura (HATOUM, 2008, p. 273).

Em estudo de Eduardo de Assis Duarte ${ }^{252}$, publicado pela Universidade Federal de Minas Gerais ${ }^{253}$, o pesquisador afirma que a viagem de Jorge Amado pelas Américas (incluindo Uruguai, Argentina, Chile, Peru e México) trouxe uma experiência ao mesmo tempo literária e pessoal ao escritor. Citando Roger Bastide, o pesquisador defende a ideia de que Jorge Amado, "ao penetrar nas raízes da injustiça que imperava nas relações de trabalho figuradas em seus textos, transformava o Nordeste brasileiro numa categoria universal" (DUARTE, 2002, p. 233). Isso explicaria, segundo ele, a grande aceitação da sua obra no exterior.

Ainda, segundo Duarte,

há de se ressaltar que a internacionalização da obra não fará dela uma literatura cosmopolita ao pé da letra. É fato que Capitães da areia foi quase todo composto durante a viagem de que falamos [...]. Mas é fato também que isto não interfere no localismo retratado, nem impede a obra amadiana de prosseguir cada vez mais (DUARTE, 2002, p. 233234).

251 Milton Hatoum (1952), escritor, tradutor e professor.

252 Eduardo de Assis Duarte, Doutor em Teoria da Literatura e Literatura Comparada pela USP Pesquisador da UFMG, atua como professor colaborador do Programa de Pós-graduação em Letras: Estudos Literários.

253 Publicado na revista Aletria - 2002234. Disponível em: http://www.letras.ufmg.br/poslit (acesso em 20/04/2015). 
Para Milton Hatoum, Capitães da Areia é uma obra atemporal e continua atual, especialmente devido à sua temática que evoca "um drama humano que ainda perdura":

Mais de setenta anos depois da primeira edição, Capitães da Areia continua a ser lido não apenas como um registro social de uma época e de um lugar específico, mas também como uma obra literária que habilmente soube evocar um drama humano que ainda perdura (HATOUM, 2008, p. 278).

Com traduções para o alemão, árabe, croata, espanhol, francês, grego, húngaro, inglês, italiano, japonês, libanês, norueguês, russo, tcheco e ucraniano (Figura 2) ${ }^{254}$, Capitães da Areia é o romance de Jorge Amado mais vendido no Brasil entre todas as obras do autor 255 .
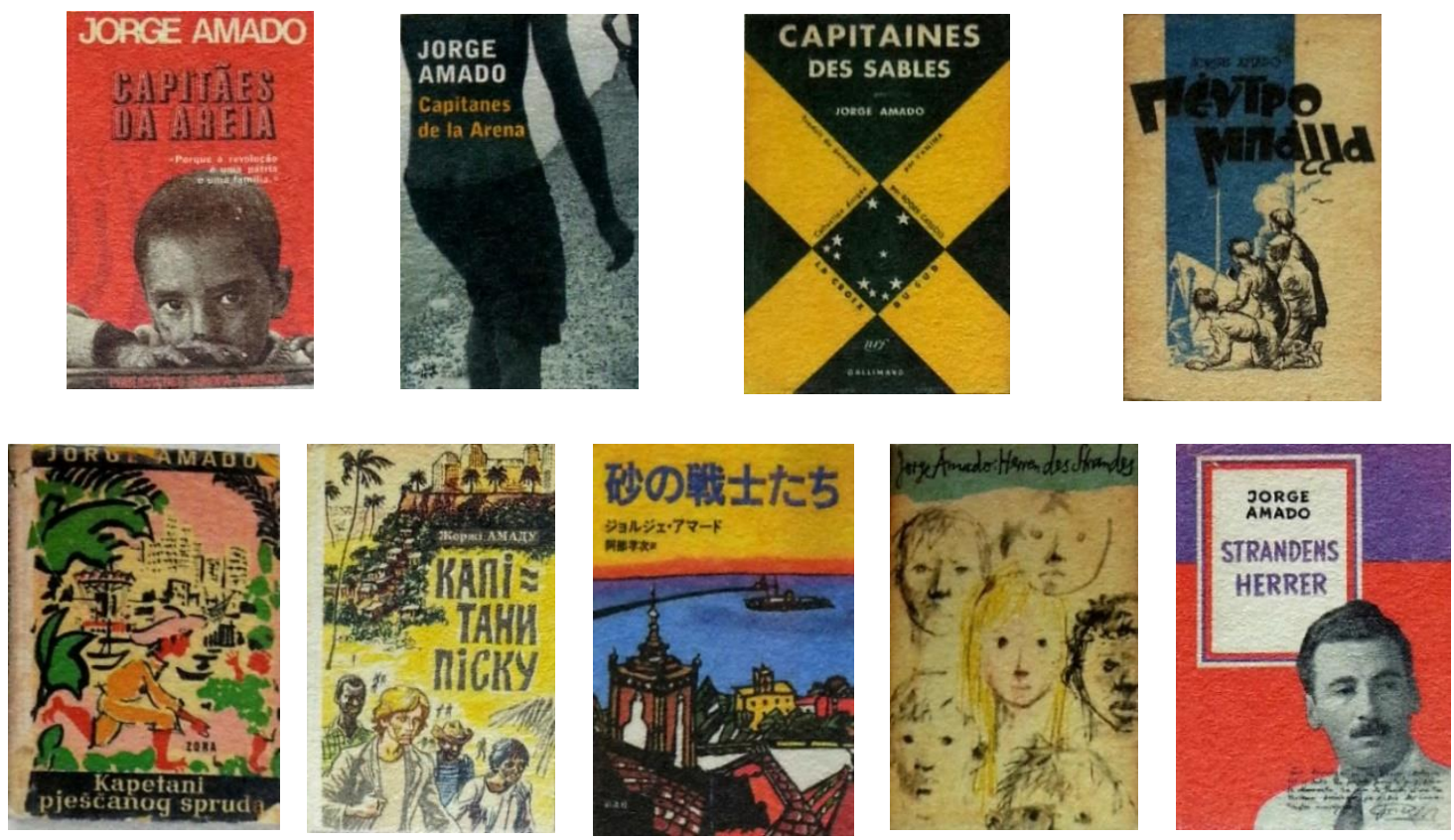

FIGURA 2 - Capas de traduções de Capitães de Areia pelo mundo. Na ordem, da esquerda para a direita, de cima para baixo, edições portuguesa, espanhola, francesa, grega, croata, ucraniana, japonesa, alemã e norueguesa ${ }^{256}$.

254 De acordo com informações da Casa Fundação Jorge Amado (jorgeamado.org.br; acesso em 21/04/2015).

255 Segundo dados publicados pela Folha de S. Paulo, em agosto de 2001, por ocasião da morte de Jorge Amado, Capitães da Areia, seu romance mais vendido, teria contabilizado ao longo dos anos 4,3 milhões de cópias.

${ }^{256}$ Fonte: Acervo Fundação Casa de Jorge Amado. In: AMADO, J., 2008 (Apêndice). 
Para Zelia Gattai, o fato de Jorge Amado ter partido de suas experiências reais - vividas na infância e na juventude - para compor sua obra contribui para o seu sucesso e para grande aceitação do público:

\begin{abstract}
A temática das crianças que vivem nas ruas continua bastante atual. Para escrever Capitães da Areia, Jorge Amado foi dormir no trapiche com os meninos. Isso ajuda a explicar a riqueza de detalhes, o olhar de dentro e a empatia que estão presentes na história. ${ }^{257}$
\end{abstract}

De fato, mesmo apresentando o distanciamento da terceira pessoa, o narrador de Capitães da Areia consegue conduzir o leitor para dentro do trapiche onde os meninos vivem e se escondem, para que ele, leitor, também possa vivenciar de perto a pobreza, a miséria, o abandono, a dor e a dura realidade dos meninos de rua.

Iniciado de forma inusitada, com a apresentação de excertos de reportagens de jornal, denúncias, cartas e réplicas sobre o grupo de crianças criminosas que atormenta e amedronta a cidade da Bahia ${ }^{258}$ com seus furtos e "aventuras sinistras", o romance primeiramente nos revela a realidade do ponto de vista da sociedade "distinta" e "aristocrática" assustada, que se apavora frente à audácia dos Capitães da Areia, para depois nos apresentar o areal e o cais, a fim de que possamos imitar o autor, e "dormir no trapiche com os meninos".

Desse modo, a frase que inaugura a narrativa de Capitães da Areia - "Sob a lua, num velho trapiche abandonado, as crianças dormem" - fornece desde o princípio indícios de como se direcionará a saga desses personagens, menores abandonados que encontram, no crime e na mendicidade, a garantia de sua subsistência. Para o narrador, são apenas "crianças", cujas infâncias foram roubadas.

${ }^{257}$ AMADO, Zelia Gattai (citação) in: AMADO, 2008, p. 271.

${ }^{258}$ A capital Salvador, por muitas vezes mencionada como "cidade da Bahia". 


\section{3 "Sob a lua, num velho trapiche abandonado"}

"Crianças Ladronas" é o título da reportagem que abre o primeiro capítulo de Capitães da Areia, intitulado "Cartas à redação". Ainda sem a presença do narrador, o romance oferece ao leitor, nessas primeiras páginas, um minucioso relato jornalístico sobre um grupo de meninos de rua, pequenos larápios que "infestam" a cidade de Salvador, conhecidos como "Capitães da Areia". Diz um dos "recortes":

Já por várias vezes o nosso jornal, que é sem dúvida o órgão das mais legítimas aspirações da população baiana, tem trazido notícias sobre a atividade criminosa dos Capitães da Areia, nome pelo qual é conhecido o grupo de meninos assaltantes e ladrões que infestam a nossa urbe. [...] Esse bando que vive da rapina se compõe, pelo que se sabe, de um número superior a cem crianças das mais diversas idades, indo desde os oito aos dezesseis anos. Crianças que, naturalmente devido ao desprezo dado à sua educação por pais pouco servidos de sentimentos cristãos, se entregaram no verdor dos anos a uma vida criminosa. São chamados de Capitães da Areia porque o cais é o seu quartel-general. E têm por comandante um molecote dos seus catorze anos, que é o mais terrível de todos [...] (AMADO, 2008, p. 11).

Após apresentar um breve panorama do que viria a ser esse "grupo de meninos assaltantes e ladrões", o jornal - de cunho sensacionalista - delonga-se na exposição pormenorizada dos fatos ocorridos no mais recente assalto praticado pelo bando na mansão de um comendador.

Ao analisar essa "reportagem jornalística", é importante perceber o tom declaradamente tendencioso das descrições, no uso de expressões e nos termos empregados para qualificar tanto o local do assalto como os assaltantes. Assim, temos, para o primeiro, atribuições como "bela vivenda"; "palacete" de "arquitetura colonial"; "remanso de paz e trabalho honesto". Já para o grupo de meninos, são usadas expressões como "bando de demônios", "molambos", "incômodos visitantes". 
Desse modo, apesar de abster-se de um "narrador" nesse primeiro momento, o romance atribui ao jornal um caráter folhetinesco, provendo-lhe de voz para apresentar a "sua" visão no relato dos fatos, fornecendo ao leitor o ponto de vista dos "moradores do aristocrático bairro", assustados com essa "malta de jovens bandidos" (AMAD0, 2008, p. 12-13).

Outro significativo fragmento da reportagem do qual se pode apreender a parcialidade jornalística no relato dos fatos é quando se faz a descrição do menino Raul Ferreira, neto do comendador, que visitava o avô no momento do assalto:

Aconteceu que no jardim a linda criança que é Raul Ferreira, de onze anos, neto do comendador, que se achava de visita aos avós, conversava com o chefe dos Capitães da Areia, que é reconhecível devido a um talho que tem no rosto. Na sua inocência, Raul ria para o malvado, que sem dúvida pensava em furtá-lo (AMADO, 2008, p. 13).

Nota-se o uso das expressões "linda criança" e "na sua inocência" para revelar a beleza e a fragilidade típicas da infância presentes no menino Raul, enquanto, para o chefe dos Capitães da Areia, apenas três anos mais velho - definido pelo próprio jornal como "um molecote dos seus catorze anos" -, é usado o termo "malvado", além de se registrar um pré-julgamento acerca de suas prováveis intenções ao abordar o abastado menino: "sem dúvida pensava em furtá-lo".

Em outro trecho, mais adiante, a reportagem divulga fragmento de uma entrevista com o menino Raul, revelando a sua conversa com o "desalmado" chefe da quadrilha, sem perder a oportunidade de novamente qualificar de modo positivo a "exemplar criança":

A nossa reportagem ouviu também o pequeno Raul, que, como dissemos, tem onze anos e já é dos ginasianos mais aplicados do Colégio Antônio Vieira. Raul mostrava uma grande coragem, e nos disse acerca da sua conversa com o terrível chefe dos Capitães da Areia (AMADO, 2008, p. 14). 
Assim, mais uma vez é possível perceber a contraposição criada pela reportagem: de um lado uma criança "idealizada”, um dos "ginasianos mais aplicados do Colégio", que demonstra "grande coragem", apesar da inocência; do outro lado, o "terrível" delinquente.

Porém, do mesmo modo que insiste em criar uma imagem deplorável e agressiva dos meninos de rua, o jornal oferece ao leitor, como contraste, o "ingênuo" ponto de vista da criança, na fala do menino Raul, que não vê senão aventura e liberdade no modo de vida do outro, tomando-o como um "personagem de cinema":

Ele disse que eu era um tolo e não sabia o que era brincar. Eu respondi que tinha uma bicicleta e muito brinquedo. Ele riu e disse que tinha a rua e o cais. Fiquei gostando dele, parece um desses meninos de cinema que fogem de casa para passar aventuras (AMADO, 2008, p. 14).

Uma visão sociopolítica também pode ser depreendida nessa inocente fala de Raul: de um lado o capitalismo, representado por "uma bicicleta e muito brinquedo"; de outro o socialismo - "a rua e o cais". Nota-se mais uma vez a contraposição de ideias e de diferentes realidades, que extrapolam a questão envolvendo apenas os aspectos econômicos - ricos versus pobres -, mas revelam, ainda que de forma velada, uma ideologia que aflora pouco a pouco na obra, desde o seu princípio.

Outra dualidade que pode ser lida nesse mesmo trecho é a de liberdade versus confinamento, representada também pela fala do chefe dos ladrões: "Ele riu e disse que tinha a rua e o cais". Como se dissesse: "não trocaria a minha liberdade pelos seus brinquedos e sua bicicleta". Essa questão sobre a liberdade dos meninos de rua ainda seria retomada outras vezes durante o romance, por isso a ela voltaremos no final desta análise. Porém o diálogo entre o menino rico e o chefe dos Capitães da Areia chama a atenção do jornalista também para "outro delicado problema": o "perigo" da influência do cinema para a infância, responsável por infundir "ideias erradas" acerca da vida na cabeça das crianças: 
Ficamos então a pensar neste outro delicado problema para a infância que é o cinema, que tanta ideia errada infunde às crianças acerca da vida. Outro problema que está merecendo a atenção do dr. juiz de menores (AMADO, 2008, p. 14).

Assim, com essa crítica explícita ao cinema - que no início do século XX avançava a passos largos para tornar-se um grande setor de entretenimento e, consequentemente, de disseminação de ideias e de formação de opiniões, tanto para adultos como para crianças -, finda-se a reportagem, abrindo-se espaço para, em seguida, apresentarem-se algumas "cartas à redação", publicadas nos dias subsequentes à veiculação da notícia, nas quais se comenta o assunto. Desse modo, divulgam-se as cartas de um secretário do chefe de polícia, um juiz de menores, uma mãe, um padre e um diretor de reformatório, oferecendo ao leitor diferentes pontos de vista sobre a situação dos meninos de rua da cidade de Salvador e sobre a criminalidade, de modo geral. Nos documentos, são abordadas desde questões políticas e sociais, até o papel dos problemáticos reformatórios, locais para os quais as crianças abandonadas eram levadas e que, de acordo com os relatos, abusavam dos castigos corporais como métodos de correção.

Após municiar o leitor com os fatos e acontecimentos relatados no preâmbulo das cartas e reportagens que integram o primeiro capítulo do romance, entra em cena o narrador.

Diferentemente do tom acusatório deflagrado no excerto jornalístico contra os malfeitores, o narrador propõe um discurso bem mais apaziguador, conduzindo o leitor diretamente ao trapiche para que ele possa presenciar de perto o modo de vida dos meninos infratores. Assim, em sua primeira aparição, em vez de usar termos como "ladrões", "molambos", "delinquentes" ou "bando de demônios" para designar os menores, o narrador refere-se a eles apenas como "crianças", sem qualquer adjetivo que as qualifique como criminosas ou perversas. Pelo contrário, o lirismo se faz presente nessa voz onisciente do narrador em grande parte dos relatos e representações 
envolvendo os meninos. A apresentação das crianças dormindo e iluminadas pela luz da lua confere aos Capitães da Areia uma aparência ainda mais pueril:

Sob a lua, num velho trapiche abandonado, as crianças dormem. Antigamente aqui era o mar. [...] A água passava por baixo da ponte sob a qual muitas crianças repousam agora, iluminadas por uma réstia amarela de lua (AMADO, 2008, p. 27).

Para descrever as crianças, o narrador faz uso de termos inócuos, como "meninos, moleques de todas as cores e de idades as mais variadas". Já para relatar suas atividades ilícitas e os "objetos", resultado dos roubos e furtos praticados, são usadas as expressões "trabalho do dia" e "estranhas coisas", respectivamente:

Logo depois transferiram para o trapiche o depósito dos objetos que o trabalho do dia lhes proporcionava. Estranhas coisas entraram então para o trapiche. Não mais estranhas, porém, que aqueles meninos, moleques de todas as cores e de idades as mais variadas, desde os nove aos dezesseis anos, que à noite se estendiam pelo assoalho e por debaixo da ponte e dormiam [...] (AMADO, 2008, p. 27).

Após contextualizar a história da formação do grupo dos Capitães da Areia e de identificar seu atual chefe, Pedro Bala, o narrador vai intercalando relatos dos acontecimentos envolvendo o grupo com descrições de situações recuperadas em flashback da vida daqueles que formam a base do núcleo principal do bando, juntamente com o protagonista. Desse modo, são apresentados os personagens João Grande, SemPernas, Professor, Pirulito, Gato, Boa-Vida, Volta Seca, além de outros integrantes secundários, como Almiro e Barandão. Cada história de vida é acompanhada por uma breve exposição envolvendo uma tragédia particular, uma fatalidade ou um 
acontecimento que mudaria para sempre a vida daquelas crianças e daqueles adolescentes: um pai morto a bala, um atropelamento, um padrasto cruel, uma mãe assassinada... ${ }^{259} \mathrm{E}$, assim, os meninos de histórias de vida variadas, mas semelhantes, vão se encontrando no trapiche para, juntos, formarem uma grande família:

\begin{abstract}
Ali estavam mais ou menos cinquenta crianças, sem pai, sem mãe, sem mestre. Tinham de si apenas a liberdade de correr nas ruas. Levavam vida nem sempre fácil, arranjando o que comer e o que vestir, ora carregando uma mala, ora furtando carteiras e chapéus, ora ameaçando homens, por vezes pedindo esmola. [...] Nenhuma delas reclamava. [...] Nunca, porém, era como um menino que tem sua casa. [...] Todos procuravam um carinho [...] (AMADO, 2008, p. 46-47).
\end{abstract}

\title{
4.4 As luzes do carrossel e o resgate da infância
}

Embora, segundo o narrador, as crianças tivessem apenas entre nove e dezesseis anos de idade, a maioria já mostrava comportamento de homens feitos, como se constatará nas descrições que se avolumam no decorrer do romance. Desse modo, eles fumam cigarros ou pontas de charutos, fazem uso de bebidas alcoólicas, organizam e praticam crimes, e mostram intensa intimidade com a sua própria sexualidade, falando de mulheres, experimentando os prazeres do sexo com os companheiros ou "derrubando negrinhas" no areal. Porém, além dessas atividades típicas da vida adulta, em algumas passagens revela-se ainda o oculto desejo de proteção e de um carinho

\footnotetext{
${ }^{259}$ No início da trama, quando apresenta os personagens, o narrador revela a idade e a história de alguns integrantes do grupo: assim, Pedro Bala, quinze anos, vivia nas ruas há dez. Desde os cinco anos, quando ficou órfão de pai; não conhecera a mãe. João Grande, treze anos, engajou aos nove anos no grupo; órfão de pai, atropelado por um caminhão. Sem-Pernas, dezesseis anos, nunca tivera família; vivia com um padeiro que o surrava. Fugiu, sofreu de fome, e foi preso. Na cadeia apanhou ainda mais. Gato, catorze anos, viera do bando dos Î́ndios Maloqueiros. E assim por diante.
} 
parental, bem como a vontade de ser apenas criança, manifestada nos sonhos e nas brincadeiras dos meninos.

Um exemplo de como a infância poderia lhes ser restituída por meio do lúdico é o capítulo "As luzes do carrossel”, que narra a passagem do "Grande Carrossel Japonês"260 pela cidade da Bahia. No episódio, dois integrantes dos Capitães da Areia são convidados pelo proprietário do brinquedo a ajudar no seu funcionamento: Volta Seca, vendendo os bilhetes, e Sem-Pernas, operando o motor. Na primeira noite em que trabalham na montagem do carrossel, os meninos convidam os demais companheiros para vê-lo funcionar. A descrição do narrador quando a "velha música" da pianola começa a tocar é a seguinte:

O sertanejo trepou no carrossel, deu corda na pianola e começou a música de uma valsa antiga. [...] Escutavam religiosamente aquela música que saía do bojo do carrossel na magia da noite da cidade da Bahia só para os ouvidos aventureiros e pobres dos Capitães da Areia. Todos estavam silenciosos. [...] Então a luz da lua se estendeu sobre todos, as estrelas brilharam ainda mais no céu, o mar ficou de todo manso (talvez que Iemanjá tivesse vindo também ouvir a música) e a cidade era como que um grande carrossel onde giravam em invisíveis cavalos os Capitães da Areia. Nesse momento de música eles sentiramse donos da cidade. E amaram-se uns aos outros, se sentiam irmãos, porque eram todos eles sem carinho e sem conforto e agora tinham o carinho e conforto da música (AMADO, 2008, p. 68).

Nesse primeiro momento, é somente a música que faz o papel dos genitores, nutrindo seus filhos de carinho e conforto, unindo-os como uma grande família.

Depois, o narrador apresenta as emoções individuais de Volta Seca e SemPernas ao experimentarem pela primeira vez o carrossel. 0 primeiro, que sonhava em ser cangaceiro e participar do grupo de Lampião, consegue materializar na sua passagem pelo brinquedo o seu sonho de menino, que se concretizaria mais tarde, sem que ele ainda o soubesse:

\footnotetext{
260 De acordo com o narrador, o "grande carrossel japonês não era senão um pequeno carrossel nacional, que vinha de uma triste peregrinação pelas paradas cidades do interior naqueles meses de inverno, quando as chuvas são longas e o Natal está muito distante ainda" (AMADO, 2008, p. 63).
} 
[...] o menino toma o cavalo que serviu a Lampião. E enquanto dura a corrida, vai pulando como se cavalgasse um verdadeiro cavalo. E faz movimentos com o dedo, como se atirasse nos que vão na sua frente, $\mathrm{e}$ na sua imaginação os vê cair banhados em sangue, sob os tiros da sua repetição. E o cavalo corre e cada vez corre mais, e ele mata a todos, porque são todos soldados ou fazendeiros ricos. Depois possui nos bancos a todas as mulheres, saqueia vilas, cidades, trens de ferro, montado no seu cavalo, armado com seu rifle (AMADO, 2008, p. 70).

Já Sem-Pernas, definido pelo narrador como um dos mais sarcásticos e ressentidos do grupo - o que se atribui, em parte, ao seu defeito físico (a perna coxa, que lhe rendeu o apelido), à sua triste história de orfandade e fome, e ainda à terrível experiência vivida na cadeia, quando fora agredido sem piedade pelos soldados -, por um momento se esquece de todo o sofrimento e vive apenas a alegria de ser criança, como "aqueles meninos que têm pai e mãe, e uma casa e quem os beije e quem os ame":

\begin{abstract}
Depois vai o Sem-Pernas. Vai calado, uma estranha comoção o possui. Vai como um crente para uma missa, um amante para o seio da mulher amada, um suicida para a morte. Vai pálido e coxeia. Monta um cavalo azul que tem estrelas pintadas no lombo de madeira. Os lábios estão apertados, seus ouvidos não ouvem a música da pianola. Só vê as luzes que giram com ele e prende em si a certeza de que está num carrossel, girando num cavalo como todos aqueles meninos que têm pai e mãe, e uma casa e quem os beije e quem os ame. Pensa que é um deles e fecha os olhos para guardar melhor esta certeza. Já não vê os soldados que os surraram, o homem de colete que ria. Volta Seca os matou na sua corrida. O Sem-Pernas vai teso no seu cavalo. É como se corresse sobre o mar para as estrelas, na mais maravilhosa viagem do mundo. Uma viagem que Professor nunca leu nem inventou. Seu coração bate tanto, tanto, que ele o aperta com a mão (AMADO, 2008, p. 70).
\end{abstract}

Desse modo, uma única experiência de "brincadeira" proporciona aos dois meninos sensações opostas: para Volta Seca, a viagem no carrossel transporta-o na sua fantasia para o futuro, em que ele já se vê como integrante do grupo de Lampião, fuzilando soldados e fazendeiros, saqueando trens e cidades, possuindo mulheres. Já 
para Sem-Pernas, o carrossel é apenas um brinquedo a que ele agora tem direito, como uma criança "que tem pai e mãe", além de uma casa, carinho e afeto. No fundo, o carrossel o transporta para seu passado ideal, um passado que nunca houve e nunca haverá, senão na sua imaginação. E a ideia desse passado fictício faz com que ele - pelo menos no espaço de tempo em que gira o carrossel e o sonho se traduz em realidade se esqueça totalmente dos pesadelos que o assombram e perseguem, transportando-o "sobre o mar para as estrelas" nessa "mais maravilhosa viagem do mundo".

Após descrever as sensações particulares de cada um dos dois meninos que trabalham no carrossel e podem vivenciar mais de uma vez a emoção de ver o mundo rodar, o narrador conta como foi a experiência coletiva dos demais componentes dos Capitães da Areia, que tiveram para si uma madrugada de glória e esplendor, "cavalgando os ginetes" e "girando com as luzes". É esse, sem dúvida, no romance, o momento mais sublime dos menores enquanto "família", agora não mais travestidos de homens feitos e de ladrões temidos, que aterrorizam com sua audácia a cidade da Bahia, mas em uma noite em que puderam ser apenas "iguais às demais crianças":

Pela madrugada os Capitães da Areia vieram. O Sem-Pernas botou o motor para trabalhar. Eles esqueceram que não eram iguais às demais crianças, esqueceram que não tinham lar, nem pai, nem mãe, que viviam de furto como homens, que eram temidos na cidade como ladrões. [...] Esqueceram tudo e foram iguais a todas as crianças, cavalgando os ginetes do carrossel, girando com as luzes. As estrelas brilhavam, brilhava a lua cheia. Mas, mais que tudo, brilhavam na noite da Bahia as luzes azuis, verdes, amarelas, roxas, vermelhas do Grande Carrossel Japonês (AMADO, 2008, p. 82).

O capítulo "As luzes do carrossel" também traz novamente à tona a discussão sobre a liberdade dos meninos de rua, já apresentada na reportagem "Crianças ladronas", quando o neto do comendador, Raul, revela a conversa que tivera com o chefe dos Capitães da Areia, Pedro Bala, comparando-o àqueles "meninos de cinema que fogem de casa para passar aventuras" (AMADO, 2008, p. 14); ou ainda nas divagações 
de Sem-Pernas enquanto observa as crianças dormirem no trapiche, e conclui que "a alegria daquela liberdade era pouca para a desgraça daquela vida" (p. 46).

Nesse capítulo entra em cena novamente o Padre José Pedro, já apresentado previamente em uma das cartas publicadas pelo jornal, logo no início do romance, em que o religioso faz graves denúncias sobre a violência praticada contra as crianças internas, conduta testemunhada por ele no reformatório de menores. 0 narrador recupera então em flashback o momento em que o padre se aproxima de Boa-Vida para tentar, por meio dele, chegar até os líderes dos Capitães da Areia, fato com que sonhava desde que tomou conhecimento do grupo:

Seu maior desejo era conhecer os Capitães da Areia. 0 problema dos menores abandonados e delinquentes, que quase não preocupava a ninguém em toda a cidade, era a maior preocupação do padre José Pedro. Ele queria se aproximar daquelas crianças não só para trazê-las para Deus, como para ver se havia algum meio de melhorar sua situação (AMADO, 2008, p. 74).

Ganhando a confiança das crianças, o padre almejava tirá-las daquela vida de "fome e abandono", destinando-os a lares de algumas "beatas velhas e religiosas que poderiam tratar de educá-los e alimentá-los". Porém, ao conhecer mais de perto os meninos e sua "filosofia de vida", percebeu que isso não seria possível e que seria perda de tempo insistir nessa opção:

Numa coisa se enganou, a princípio, o padre José Pedro: em lhes oferecer, em troca do abandono da liberdade que gozavam, soltos na rua, uma possibilidade de vida mais confortável. [...] isso seria o abandono de tudo de grande que tinha a vida deles: a aventura da liberdade nas ruas da mais misteriosa e bela das cidades do mundo, nas ruas da Bahia de Todos-os-Santos. E logo que, por intermédio de BoaVida, o padre José Pedro fez relações com os Capitães da Areia, viu que se lhes fizesse essa proposta perderia toda a confiança que já depositavam nele [...] (AMADO, 2008, p. 75). 
Assim, o padre não abandonou sua ideia inicial de ajudar as crianças, sem, contudo, interferir demais no seu modo de vida. Afinal, como registrado na conversa divulgada no jornal, eles não precisavam de brinquedos e bicicletas; pois tudo o que eles tinham eram "as ruas, e o cais".

Ainda nesse capítulo, o narrador descreve uma cena em que o padre, em companhia de Pedro Bala e outros integrantes dos Capitães da Areia, é abordado por uma senhora, a viúva Margarida Santos, que lhe questiona sobre sua proximidade com os pequenos marginais, travando-se o seguinte diálogo:

- O senhor não se envergonha de estar nesse meio, padre? Um sacerdote do Senhor? Um homem de responsabilidade no meio dessa gentalha...

- São crianças, senhora. [...] Cristo disse: "Deixar vir a mim as criancinhas...".

- Criancinhas... Criancinhas... - cuspiu a velha. [...] Isso não são crianças, são ladrões. Velhacos, ladrões. Isso não são crianças. São capazes até de ser dos Capitães da Areia. Ladrões (AMADO, 2008, p. 81).

Nesse diálogo, o leitor volta a se deparar com o tom acusatório que, no início do romance, foi propagado pela reportagem jornalística, quando os meninos são tratados por "bando", "ladrões", "delinquentes" e "assaltantes". Aqui, a figura da viúva é construída com antipatia pelo narrador, como sinônimo de opulência e arrogância, descrita como uma "velha magra" portando um lorgnon de ouro e, em seu peito, um "barret custosíssimo" que "brilhava à luz do sol".

Por meio desse episódio, é possível voltar à questão da identidade dos menores: afinal, os Capitães da Areia eram crianças ou ladrões? Para a viúva Margarida, eram "ladrões", "gentalha", "imundície". Para o padre, apenas crianças. Crianças cujas infâncias foram "roubadas". 


\subsection{Infâncias roubadas}

Dois personagens do romance podem ser citados para exemplificar a dualidade adulto-criança que permeia a vida dos Capitães da Areia: Sem-Pernas e Gato.

O primeiro, de acordo com o narrador, nunca tivera família. Criado por um padeiro que o surrava, fugiu "logo que pôde compreender que a fuga o libertaria" (AMADO, 2008, p. 38). Porém, antes de se juntar aos Capitães da Areia, Sem-Pernas viveu nas ruas, passou fome e foi preso. Na cadeia, foi humilhado e apanhou. Logo que incorporado ao grupo, passou a ser um dos líderes, e era comumente usado como "isca" para atrair a simpatia e a solidariedade das pessoas, enganando senhoras que se compadeciam de sua dor. E embora fosse um dos mais "temidos" no grupo, era também um dos mais carentes, e almejava ser amado, não por uma mulher, como outros, mas por uma mãe, por uma família:

Ele queria uma coisa imediata, uma coisa que pusesse seu rosto sorridente e alegre, que o livrasse da necessidade de rir de todos e de rir de tudo. Que o livrasse também daquela angústia, daquela vontade de chorar que o tomava nas noites de inverno. [...] Queria alegria, uma mão que o acarinhasse, alguém que com muito amor o fizesse esquecer o defeito físico e os muitos anos (talvez tivessem sido apenas meses ou semanas, mas para ele seriam sempre longos anos) que vivera sozinho nas ruas da cidade, hostilizado pelos homens, empurrado pelos guardas, surrado pelos moleques maiores. Nunca tivera família (AMADO, 2008, p. 38).

Não por acaso é no capítulo intitulado "Família” que Sem-Pernas vive seu principal dilema: escolhido por Pedro Bala para entrar em uma rica mansão, passandose por um pobre órfão aleijado em busca de trabalho, Sem-Pernas deveria em poucos dias observar onde estavam os objetos de valor da casa para então dar o relatório aos Capitães da Areia, facilitando o assalto. Porém ele não imaginava que a rica senhora, dona Ester, que perdera recentemente o filho, se afeiçoasse tanto a ele, dando-lhe não somente o de comer e o de vestir, mas também o carinho com que ele tanto sonhara. 
Muitas vezes já fizera aquilo: penetrar em casas de uma família como um menino pobre, órfão e aleijado e neste título passar os dias necessários para fazer um reconhecimento completo da casa, dos lugares onde guardavam os objetos de valor, das saídas fáceis para uma fuga [...] Mas desta vez estava sendo diferente. Desta vez não o deixaram na cozinha com seus molambos, não o puseram a dormir no quintal. Deram-lhe roupa, um quarto, comida na sala de jantar (AMADO, 2008, p. 124-125).

Depois de conversar com o marido e acertar a permanência de Sem-Pernas na família, dona Ester despediu-se do menino com afeto, colocando-o para dormir, e dizendo "Boa noite, meu filho". A reação de Sem-Pernas é de paralisação e perplexidade diante da demonstração de carinho:

O Sem-Pernas ficou parado, sem um gesto, sem responder sequer o boanoite, a mão no rosto, no lugar em que dona Ester o beijara. Não pensava, não via nada. Só a suave carícia do beijo, uma carícia como nunca tivera, uma carícia de mãe. Só a suave carícia no seu rosto. Era como se o mundo houvesse parado naquele momento do beijo e tudo houvesse mudado. Só havia no universo inteiro a sensação suave daquele beijo maternal na face do Sem-Pernas (AMADO, 2008, p. 127128).

Desse modo, Sem-Pernas decide postergar o plano, para vivenciar por mais tempo aquela "infância idealizada" que nunca tivera antes, com brincadeiras com um gato no jardim, livros ilustrados, roupa de qualidade e comida na mesa, além de ida ao cinema, sorvete, carinho a todo momento. Porém o contato com Pedro Bala o traz de volta à realidade: ele então se lembra dos outros meninos do trapiche e sente-se mal pelos privilégios que os outros não tinham. Assim, no grande dilema entre trair dona Ester e seu marido, que lhe deram tudo como a um filho, e trair os Capitães da Areia, sua verdadeira família, ele opta pelo primeiro, sem, contudo, deixar de sentir-se 
terrivelmente insidioso e desleal. Por isso chora, e é prontamente consolado por sua "mãezinha", que mal suspeitava do real motivo de sua tristeza:

Dona Ester o beijou na face onde as lágrimas corriam: "Não chore, que sua mãezinha fica triste". Então os lábios do Sem-Pernas se descerraram e ele soluçou, chorou muito encostado ao peito de sua mãe. E enquanto a abraçava e se deixava beijar, soluçava porque a ia abandonar e, mais que isso, a ia roubar. E ela talvez nunca soubesse que o Sem-Pernas sentia que ia furtar a si próprio também. Como não sabia que o choro dele, que os soluços dele eram um pedido de perdão (AMADO, 2008, p. 132).

Esse seu pensamento, de que “ia furtar a si próprio também”, era a consciência da sua infância roubada; e que poderia, de certo modo, voltar a ter, mas não teria.

O segundo personagem que vive a dualidade adulto-criança é Gato, que também nunca tivera família, e chegou à Bahia na "rabada de um trem", vindo do meio dos Índios Maloqueiros, "crianças que vivem sob as pontes de Aracaju” (AMADO, 2008, p. 40). Logo que chegou mostrou que era um dos mais ágeis e exímios trapaceadores do grupo. Era também o mais elegante, e gostava de sair à noite para conquistar mulheres. Logo se encantou pela prostituta Dalva, tornando-se seu amante, apesar de ter apenas catorze anos. Nas ruas da Bahia, as mulheres o chamam de "frangote" e zombam da sua audácia. Porém até o mulherengo e namorador Gato tem a sua noite de criança. É quando entra em cena a figura de Dora, uma menina órfã encontrada por João Grande e Professor, e adotada pelo grupo, juntamente com o irmão pequeno, Zé Fuinha. A chegada de Dora ao trapiche inicialmente não foi bem recebida pelo bando e trouxe alguns conflitos, porém logo Pedro Bala convenceu-se de que a menina poderia ficar. A presença de uma menina no grupo mudou o comportamento e o sentimento de alguns integrantes. Em uma das cenas mais ternas narradas do romance, Gato pede um favor à menina: ajudá-lo a enfiar a linha na agulha, atividade para a qual não tinha a menor habilidade. Seu desejo era remendar o bolso de um paletó rasgado, e uma camisa. Dora faz além do pedido do menino; oferece-se para ajudá-lo a costurar: 
A camisa estava rasgada de cima a baixo. Dora mandou que ele sentasse começou a coser no corpo dele mesmo. Quando os dedos dela tocaram pela primeira vez nas costas de Gato, ele sentiu um arrepio. Como quando Dalva passava as unhas crescidas e tratadas, arranhando suas costas [...]. Mas Dalva não cosia suas roupas, talvez nem soubesse enfiar uma linha no fundo de uma agulha. E Dora [...] não queria excitar, ou arrepiar. Passava como a mão de uma mãe que remendava camisas do filho (AMADO, 2008, p. 179).

O episódio faz com que Gato se lembre da sua própria mãe, que morrera cedo, e do hábito que ela também tinha, de coser suas camisas sem que ele as tirasse do corpo, devolvendo-lhe a sensação de cuidado e carinho que há muito não sentia. Assim, o pequeno malandro, que à primeira vista poderia ter tido um arrepio de prazer ao toque da mão de Dora - como sentia com Dalva, sua mulher, que o arranhava de propósito com suas "unhas crescidas e tratadas" -, percebeu logo a diferença, e desfrutou aqueles instantes como um momento sublime, em que a criança volta a ocupar seu lugar de direito, nas mãos delicadas de "unhas maltratadas e sujas, roídas a dente" de uma mãe postiça, também criança, mas mãe:

Dora está por detrás dele, ele não vê. Imagina então que é sua mãe que voltou. Gato está pequenino de novo, vestido com um camisolão de bulgariana e nas brincadeiras pelas ladeiras do morro o rompe todo. $\mathrm{E}$ sua mãe vem, faz com que ele se sente na sua frente e suas mãos ágeis manejam a agulha, de quando em vez o tocam e lhe dão aquela sensação de felicidade absoluta. Nenhum desejo. Somente felicidade. Ela voltou, remenda as camisas do Gato. Uma vontade de deitar no colo de Dora e deixar que ela cante para ele dormir, como quando era pequenino. Se recorda que ainda é uma criança. Mas só na idade, porque no mais é igual a um homem, furtando para viver, dormindo todas as noites com uma mulher da vida, tomando dinheiro dela. Mas nesta noite é totalmente criança, esquece Dalva, suas mãos que o arranham, lábios que prendem os seus em beijos longos, sexo que o absorve. [...] Esquece tudo, é apenas um menino de catorze anos com uma mãezinha que remenda suas camisas. [...] Os cabelos loiros dela tocam no ombro do Gato. Mas ele não tem outro desejo senão que ela continue a ser sua mãezinha. Sua felicidade naquele momento é quase absurda. É como se não houvesse existido toda a sua vida depois da morte da sua mãe. É como se tivesse se conservado uma criança igual a todas (AMADO, 2008, p. 180). 
Desse modo, o malandro, aprendiz de cafetão, jogador desonesto, portador de baralho de cartas marcadas, pequeno ladrão de joias, volta a ser apenas uma criança, cuja infância - como as carteiras que ele surrupia com agilidade descomunal -, fora sutilmente roubada.

Conforme foi possível demonstrar, Sem-Pernas e Gato vivem experiências distintas de maternidade, que os fazem esquecer, ainda que por pouco tempo, a vida de homens que levavam, roubando, fumando, bebendo e dormindo com mulheres: para Sem-Pernas, o encontro da figura materna se dá com dona Ester, que o acolheu como filho e lhe deu o carinho que ele nunca conhecera; para Gato, no gesto de Dora, por meio do qual ele pôde reviver um momento de intimidade que repousava em sua lembrança, reavivando em sua memória a confortante sensação de ser amado por uma mãe.

Outros episódios poderiam ser aqui analisados, uma vez que, no fundo, cada integrante dos Capitães da Areia traz uma história diária de luta pela sobrevivência em um mundo desigual, em que crianças sem recursos não desfrutam do direito de ser crianças, devendo agir e viver como homens, e encontrando na criminalidade uma das principais saídas, senão a única, para a sua subsistência.

Para o professor e pesquisador João Clemente Souza Neto 261 , o desenvolvimento de hábitos de furto e agressão são uma resposta das crianças e dos adolescentes que vivem nas ruas ao sofrimento causado pela rejeição e privação dos direitos a que são expostos diariamente. $\mathrm{O}$ autor define essa prática como "estratégialimite de sobrevivência dessa população" 262 :

Crianças e adolescentes que sofrem rejeição e privação dos direitos acabam por desenvolver hábitos de furto e agressão, como parte do seu cotidiano. Essa prática, mais do que um mecanismo de sobrevivência ou uma prática antissocial, é uma estratégia-limite de sobrevivência dessa população (SOUZA NETO, 2001, p. 148).

\footnotetext{
261 João Clemente de Souza Neto. Professor Adjunto, pesquisador e orientador no Programa de PósGraduação em Educação, Arte e História da Cultura e no Curso de Graduação em Pedagogia da Universidade Presbiteriana Mackenzie. Membro do Centro de Investigação em Sociologia Económica e das Organizações de Lisboa, do Grupo de Pedagogia Social da USP e líder do Grupo de Pedagogia Social da UPM.

2620 autor relata sua experiência como educador e coordenador técnico do Lar de Menores São José, em Diadema, Grande São Paulo. A pesquisa, que resultou em sua tese de doutorado, foi publicada em SOUZA NETO, João Clemente. Crianças e adolescentes abandonados: estratégias de sobrevivência. São Paulo, Arte Impressa, 2001.
} 
O autor ainda afirma que "as chamadas práticas antissociais" - como os furtos, roubos e a agressividade - não devem ser vistas somente como um desvio, mas como um "grito de socorro daqueles que tiveram destruída toda a esperança" (SOUZA NETO, 2001, p. 149). Complementa, explicando que, "na trajetória da criança abandonada",

é possível compreender um pouco a fúria avassaladora do desejo não satisfeito, das promessas não cumpridas e a omissão das políticas sociais que deveria atuar, com mais eficiência e eficácia, junto a essas tragédias (SOUZA NETO, 2001, p. 149).

A revolta de Sem-Pernas em seu derradeiro capítulo - "Como um trapezista de circo" - denota essa "fúria avassaladora", seu ódio pelos desejos não satisfeitos, pelas promessas não cumpridas:

Os guardas vêm nos seus calcanhares. [...] Não deixará que o peguem, não tocarão a mão no seu corpo. Sem-Pernas os odeia como odeia a todo mundo, porque nunca pôde ter um carinho. E no dia que o teve foi obrigado a o abandonar porque a vida já o tinha marcado demais. Nunca tiver a uma alegria de criança. Se fizera homem antes dos dez anos para lutar pela mais miserável das vidas: a vida de criança abandonada [...] Quando os corações das demais crianças ainda estão puros de sentimentos, o do Sem-Pernas já estava cheio de ódio. Odiava a cidade, a vida, os homens (AMADO, 2008, p. 25-251).

Por outro lado, Souza Neto afirma que esse sentimento de perda e abandono pode ajudar a criança ou o adolescente a desenvolver sua criatividade e seu talento:

A perda pode auxiliar o indivíduo a desenvolver sua capacidade criativa, a buscar novos espaços para construir a esperança. [...] Quando reconduzido à redescoberta dos objetos, supera a desesperança e adquire a vitalidade da esperança (SOUZA NETO, 2001, p. 151). 
É o que se revela, por exemplo, na figura de João José, o "Professor", personagem que desvia para sua habilidade no desenho, na pintura e na leitura as frustrações geradas pelo abandono. Descrito pelo narrador como "franzino, magro e triste", era um dos mais respeitados entre os Capitães da Areia por ser "o único que lia correntemente entre eles" e talvez o "único que tivesse uma certa consciência do heroico das suas vidas" (AMADO, 2008, p. 32). Antecipando os rumos finais do personagem, o narrador afirma já no início do livro que seria ele, o Professor, "quem haveria de contar em quadros que assombrariam o país a história daquelas vidas e muitas outras histórias de homens lutadores e sofredores" (p. 32).

Quando o grupo dos Capitães da Areia é apresentado ao leitor, algumas histórias de vida são reveladas com mais detalhes; outras, não. De acordo com o narrador, o grupo era composto por crianças de oito a dezesseis anos de idade, porém o próprio narrador afirma que Pedro Bala está na rua desde os cinco. Bem novo também é Zé Fuinha, irmão de Dora, que passa a integrar o bando com apenas seis anos.

No romance, os motivos que levam as crianças a ganharem as ruas são vários; a maior parte deles, a orfandade. Para João Grande, a orfandade somada ao desejo de ser livre; para Sem-Pernas, a orfandade somada a maus-tratos.

Na pesquisa de Souza Neto, o autor revela que,

nessa faixa etária (entre três e doze anos), a criança já reage aos maustratos e começa a ir para a rua. Quando localizadas por policiais, as mais novas não sabem dizer onde moram ou onde estão os pais, e as maiores, muitas vezes, não querem dar informações. Outras crianças são simplesmente abandonadas ou expulsas de casa. Pré-adolescentes e adolescentes, quando já assimilaram os hábitos da rua e adquiriram independência, apresentam dificuldades para o convívio na entidade e com uma família substituta (SOUZA NETO, 2001, p. 147-148).

Essa dificuldade para o convívio com uma família substituta é o que o Padre José Pedro constata, após conhecer de perto os Capitães da Areia e seu particular modo de viver. De acordo com as palavras do narrador, após algumas experiências 
desastrosas, o padre "viu que era absurdo" colocar um integrante do grupo para ser criado em casas de famílias de beatas, porque "a liberdade era o sentimento mais arraigado nos corações os Capitães da Areia" (AMADO, 2008, p. 77).

Desse modo, o encarceramento dos meninos de rua em reformatórios é algo ainda mais violentador. De acordo com Gregori \& Silva ${ }^{263}$, a preocupação social com o "menor" desassistido no Brasil "remonta ao século XIX, com o advento da República, e acompanha todo o processo de urbanização que atinge as grandes cidades brasileiras no início do século XX [...]” (GREGORI, 2000, p. 11). Segundo as autoras, "o primeiro código de menores é criado em 1927", ou seja, apenas uma década antes da publicação de Capitães da Areia, procurando enquadrar os "delinquentes e abandonados" com menos de 18 anos de idade, introduzindo a categoria "menor", que seria utilizada pela legislação "até fins da década de 1970". Ainda, segundo as autoras, "na década de 1920 surgem as primeiras experiências de institucionalização e internação dos 'menores' em estabelecimentos oficiais, bem como o controle sobre o trabalho praticado por meninos nas ruas"264.

A questão do reformatório é suscitada no romance já nas cartas publicadas no primeiro capítulo, em que uma mãe identificada como Maria Ricardina denuncia os maus-tratos sofridos pelo filho na instituição ("o menos que acontece pros filhos da gente é apanhar duas ou três vezes por dia”), situação confirmada pelo Padre José Pedro ("As crianças são tratadas como feras, essa é a verdade") e contestada veementemente pelo diretor do instituto, que atribui como função do reformatório apenas "a santa missão de educar" (AMADO, 2008, p. 18-21).

O assunto é retomado no capítulo "Luzes do carrossel”, durante uma descrição do narrador sobre as divagações do padre ("Ele conhecia demais as leis do reformatório, as escritas e as que se cumpriam. E sabia que não havia possibilidade de nele uma criança se tornar boa e trabalhadora"). Ainda que de forma sutil e colocada despretensiosamente no interior de um capítulo que se dedica sobretudo aos sonhos despertados pelo carrossel japonês, a expressão utilizada sobre as leis do reformatório

\footnotetext{
263 Maria Filomena Gregori e Cátia Aida Silva (Cátia Aida Silva é doutora em Ciência Política pela USP e desenvolve atividades de ensino e pesquisa no Departamento de Ciência Política da UNICAMP).

264 Essas instituições originariam, mais tarde, o SAM (anos 1940), a FUNABEM - depois FEBEM - (anos 1960), atualmente, denominada Fundação CASA (desde 2006).
} 
- "as escritas e as que se cumpriam" - denota a diferença que havia entre o regulamento e o que acontecia na prática.

Os castigos corporais e o abuso da autoridade no trato com as crianças infratoras e abandonadas ficam mais evidentes e pormenorizados no capítulo "Reformatório", que narra a captura e os dias de encarceramento, sofrimento e angústia de Pedro Bala, conduzido ao Instituto para sua regeneração, após ser preso, onde só conheceu a violência. De sua cela, ele ouve uma canção de liberdade, e planeja sua fuga:

\begin{abstract}
Na madrugada, quando Pedro acordou, os presos cantavam. Era uma moda triste. Falava do sol que havia nas ruas, em quanto é grande e bela a liberdade. [...] Pedro Bala sentia o corpo todo doer das pancadas do dia anterior. [...] Lembrava-se da canção que os presos cantavam na madrugada que nascia. Dizia que a liberdade é o bem maior do mundo. Que nas ruas havia sol e luz e nas células havia uma eterna escuridão porque ali a liberdade era desconhecida. [...] Pela liberdade o pai de Pedro Bala morrera. Pela liberdade - pensava Pedro - dos seus amigos, ele apanhara uma surra na polícia. [...] Lá fora, dizia a velha canção, é o sol, a liberdade e a vida. Pela janela Pedro Bala vê o sol, A estrada passa adiante do grande portão do reformatório. Aqui dentro é como se fosse uma eterna escuridão (AMADO, 2008, p. 201-202).
\end{abstract}

Essa necessidade de liberdade que permeia todo o romance, a começar pelo diálogo entre Pedro Bala e o menino Raul publicado no jornal da Bahia - "Ele disse que tinha a rua e o cais" -, tem então seu ápice nesses dois capítulos subsequentes, que não carecem de outra definição senão os nomes das instituições que encarceram a liberdade em nome da educação: "Reformatório" e “Orfanato".

Interessante é notar que Jorge Amado, enquanto menino grapiúna, também revela sua obsessão pela liberdade, quando é matriculado no colégio dos jesuítas, que o priva da alegria de ser criança: 
Para o menino grapiúna - arrancado da liberdade das ruas e do campo, das plantações e dos animais, dos coqueirais e dos povoados recémsurgidos -, o internato no colégio dos jesuítas foi o encarceramento, a tentativa de domá-lo, de reduzi-lo, de obrigá-lo a pensar pela cabeça dos outros (AMADO, 1982, p. 101-102).

Porém, assim como seu herói (ou, no caso de Pedro Bala, talvez seu anti-herói), o autor consegue escapar de seu encarceramento para, a partir de então, dar novos rumos à sua vida:

$\mathrm{Eu}$ acho que aquela fuga teve um papel fundamental na minha vida. Tudo partiu daí. Ela me abriu perspectivas, já que me possibilitou conhecer outros lugares, outras pessoas. As viagens foram sempre uma boa fonte de alimentação da minha obra (IMS, 1997, p. 52).

Para o menino grapiúna, a fuga do colégio interno representou o início das suas "universidades"265, como se o real aprendizado não estivesse nos livros, nos internatos, nos padres jesuítas, mas no mundo, no sertão, na vida que existia somente fora daquela "prisão".

Em Capitães da Areia, essa constante busca pela liberdade que permeia todo o romance, e que fora a motivação de Pedro Bala para fugir do reformatório, pelo resgate de Dora do orfanato, pela opção do menino João Grande pela vida nas ruas; também ela é responsável pelo suicídio de Sem-Pernas. 0 medo de ser novamente preso, confinado, surrado e humilhado faz com que o menino coxo opte pela liberdade eterna. Como um trapezista de circo, lança-se no vazio, porém ele sabe que não há outro trapézio em que se apoiar. A imagem do circo evoca naturalmente o sorriso da criança. Antes de saltar, Sem-Pernas "ri com toda a força do seu ódio" (AMADO, 2008, p. 251), uma risada de escárnio, de deboche, de menosprezo. Diferentemente daqueles dias e noites no

265 "Fugi no início do terceiro ano, atravessei o sertão da Bahia no rumo de Sergipe, iniciando minhas universidades". (AMADO, 1992, p. 120). 
carrossel, quando desfrutou da "suprema felicidade" (p. 67), e pôde proporcionar aos demais meninos, que perderam o direito à infância quando precisaram se converter em homens antes do tempo, uma emoção diferente. Naquela noite, girando com as luzes, ao som de uma valsa antiga, os Capitães da Areia "esqueceram que não tinham lar, que viviam de furto como homens, que eram temidos na cidade como ladrões" (p. 82). Foram apenas crianças.

Para Milton Hatoum, “a brincadeira no carrossel é uma pausa na vida arriscada e marginal, uma entrega à magia e ao sonho da infância", que tem o poder de "irmanar as crianças e de devolver a elas um pouco de alegria" (HATOUM, 2008, p. 278). Magia e alegria que os meninos conheciam apenas nos crimes, nas trapaças, nas noites de lua, na "larga, livre e ruidosa gargalhada dos Capitães da Areia, que era como um hino do povo da Bahia" (AMADO, 2008, p. 62).

Crianças que eram crianças só na idade. Porque fumavam, bebiam, conheciam como homens os prazeres do sexo. E, sobretudo, roubavam. Assaltavam residências de luxo, pessoas na rua; trapaceavam no jogo. Eram trombadinhas, ladrões, trambiqueiros. Ludibriavam famílias, velhas senhoras, outras crianças. Estupravam negrinhas no areal. Mas no fundo, procuravam nos roubos, nas aventuras e na vida desregrada algo que haviam perdido, ou sequer conhecido. Porque a vida há muito já lhes roubara o seu bem mais precioso: sua inocência, sua identidade, sua infância. 
"Julgo que estive meio louco. E amparei-me ansioso às figurinhas de sonho que me atenuavam a solidão. 0 mundo feito caixa de brinquedos, os homens reduzidos ao tamanho de um polegar de criança".

Graciliano Ramos (1942) 
Capítulo 5

Fragmentos de infância em Graciliano Ramos 


\title{
Capítulo 5
}

\section{Fragmentos de infância em Graciliano Ramos}

\begin{abstract}
"Um dia, [...], saí aos tombos, esbarrei com um esteio e ganhei um calombo grosso na testa. Datam desse tempo as minhas mais antigas recordações do ambiente onde me desenvolvi como um pequeno animal. Até então algumas pessoas, ou fragmentos de pessoas, tinhamse manifestado, mas para bem dizer viviam fora do espaço. [...]. Apareceram lugares imprecisos, e entre eles não havia continuidade. Pontos nebulosos, ilhas esboçando-se no universo vazio".
\end{abstract}

Graciliano Ramos

$(1939)^{266}$

\subsection{A imprecisão da memória e as lembranças como "rasgões num tecido negro"}

Graciliano Ramos ${ }^{267}$ nasceu no município de Quebrangulo, em Alagoas, em outubro de 1892. Primogênito de dezesseis filhos do casal Maria Amélia Ferreira Ramos e Sebastião Ramos de Oliveira, passou a maior parte da infância nas cidades de Buíque, em Pernambuco, e Viçosa, no Estado natal. 0 próprio escritor resume assim os primeiros anos de sua história, vividos entre a fazenda e a vila pernambucana:

\footnotetext{
Meu pai, Sebastião Ramos, negociante miúdo, casado com a filha de um criador de gado, ouviu os conselhos de minha avó, comprou uma fazenda em Buíque, Pernambuco, e levou para lá os filhos, a mulher e os cacarecos. Ali a seca matou o gado - e seu Sebastião abriu uma loja na vila. Da fazenda conservo a lembrança de Amaro Vaqueiro e de José Baía.
}

\footnotetext{
266 Embora escrito originalmente em 1939, conforme consta no manuscrito "Nuvens" (Instituto de Estudos Brasileiros - USP), o texto foi publicado no livro de memórias Infância apenas em 1945 (RAMOS, 2008, p. 12).

267 Graciliano Ramos de Oliveira (1892-1953).
} 
Na vila conheci André Laerte, cabo José da Luz, Rosenda Lavadeira, padre José Ignácio, Filipe Benício, Teotoninho Sabiá, seu Batista, dona Marocas, minha professora, mulher de seu Antônio Justino, personagens que utilizei anos depois ${ }^{268}$.

O episódio dessa mudança familiar, da fazenda para a vila em Buíque, é descrito em pormenores por Graciliano em Infância, seu livro de memórias ${ }^{269}$. Diferentemente do estilo direto e sucinto que o excerto acima revela, em Infância a mudança é revisitada vagarosamente, por meio das impressões e sensações de um menino, perturbado com as transformações experimentadas por ele não somente no cenário, que lhe era tão familiar e aprazível, mas em todo o seu entorno, nas pessoas com quem convivia e em seu próprio corpo, em que vestimentas não habituais lhe tolhiam os movimentos. Desse modo, entre brumas e nuvens, fragmentos de pessoas e cenas recortadas, o narrador vai tentando reconstituir e reescrever esse passado distante, por meio das linhas tortas da memória:

[...] os sapatos me incomodavam os dedos, esfolavam os calcanhares. Onde estariam as minhas alpercatas? Na roupa estreita, movia-me com dificuldade. Em geral usava camisa, saltava e corria como um bichinho [...]. A calça, o paletó e os sapatos pressagiavam acontecimentos volumosos. E palavras enigmáticas haviam-me despertado suspeitas vagas, medíocre entusiasmo por aventuras imprecisas e medo. Que iria suceder? Bom que José Baía estivesse comigo, papagueando na sua língua fácil e capenga, livrando-me de sustos (RAMOS, 2008, p. 46).

Por meio do relato do narrador, percebe-se o medo e a ansiedade frente ao desconhecido, fosse ele manifestado pelas "palavras enigmáticas" ou por presságios de "acontecimentos volumosos". Era preferível estar livre, saltar "como um bichinho" e

${ }^{268}$ Este depoimento de Graciliano Ramos está presente em todas as obras do escritor publicadas pela Editora Record. Sem origem e data. Interessante notar a referência que o escritor faz às pessoas que conheceu na mais tenra infância, e que, declaradamente, constituiriam matéria para que ele compusesse, mais tarde, tanto personagens de suas narrativas ficcionais como de suas crônicas e memórias.

${ }^{269}$ RAMOS, Graciliano. Infância. 39. ed. Rio de Janeiro, Record, 2008. 0 episódio é narrado nos capítulos "Chegada à vila" e "A vila" (p. 45-58). 
ouvir a fala acessível de José Baía. A simplicidade diária exposta tanto na linguagem fácil como nas roupas soltas davam lugar a um novo modo de vida que, à primeira vista, assustava o menino.

Desse modo, suas impressões acerca das alterações ocorridas em sua rotina e também daquelas que ainda estariam por vir - dão-se primeiro por meio dos sentidos: inicialmente, as mudanças em seu próprio corpo, irreconhecível, aprisionado nas incômodas roupas de viagem e nos sapatos duros. Em seguida, em seus olhos e ouvidos, que registram sensações novas, incomuns: palavras misteriosas o desorientam; pessoas desconhecidas o constrangem; o menino sente falta daqueles que lhe eram próximos e caros e do vocabulário simples que lhe era familiar: o novo o assusta. Lentamente, os sentidos vão sendo reeducados. 0 narrador então se depara com um cenário totalmente inusitado: a porta da frente e o copiar já não davam para o açude. Um mundo estranho descortina-se à sua frente. Os horizontes alargam-se. Nas palavras do menino, seu espanto:

\begin{abstract}
De repente me vi [...] em abandono completo, num mundo estranho, cheio de casas, brancas ou pintadas, sem alpendres, notáveis. Havia duas maravilhosas: uma de quadrados faiscantes, uma que montava noutra. Avizinhei-me do sobradinho, fugi medroso e confuso: nunca teria podido imaginar uma casa trepada. [...] Procurei Amaro e José Baía, debalde. Longe da fazenda, considerei-me fora da realidade e só. De fato não estava só: várias pessoas transitavam por ali, ruídos vagos quebravam o silêncio. Admirável a casa suspensa, como um garoto erguido em pernas de pau. [...] 0 paletó feria-me os sovacos, os sapatos mordiam-me os pés e tropicavam no tijolo. Senti falta da camisa e das alpercatas (RAMOS, 2008, p. 47).
\end{abstract}

A descrição do sobradinho como uma casa "que montava noutra" - ou então "suspensa, como um garoto erguido em pernas de pau" - mostra o assombro do narrador em sua percepção de menino com a amplitude que avançou sobre seu campo de visão. Para ele, tudo era grande e confuso, gerando uma profunda nostalgia pela pequenez de seu mundo próprio, seu universo particular: 
Queria ouvir histórias, risadas, cantigas. E queria ausentar-me dali, descalçar-me, ver minhas irmãs, entreter-me com o moleque José. Vaguei na calçada, coxeando, os olhos turvos, as virilhas úmidas. Senteime no chão, cansado e infeliz. Encostei-me depois a uma parede e adormeci (RAMOS, 2008, p. 49).

Por meio desses poucos fragmentos de Infância já é possível depreender os diferentes níveis de memória contidos no texto. Se por um lado existe um escritor que revisita suas experiências de menino para compor um livro de memórias, por outro lado há um menino, incomodado com as novidades que lhe são apresentadas, procurando conforto e aconchego em suas lembranças ainda mais remotas, do tempo em que vivia na fazenda.

Assim como os percursos sinuosos e insidiosos da memória, Infância não apresenta uma narrativa linear. Embora publicado somente em 1945 como livro, os 39 capítulos que compõem a obra foram escritos de forma independente ao longo de quase uma década ${ }^{270}$, o que possibilita ao leitor que os episódios sejam lidos como contos isolados, interligados por um fio condutor invisível que tece esse complexo emaranhado formado por pessoas, paisagens, fatos e acontecimentos que marcaram a história e a vida do escritor.

Nos três primeiros capítulos do livro, intitulados "Nuvens", “Manhã" e "Verão", as lembranças do narrador se refazem em cenas esparsas, vozes distantes, versos embalados em cantigas e "fragmentos de pessoas". A epígrafe que abre este capítulo, retirada das primeiras páginas de "Nuvens", demonstra como o autor se refere à dificuldade em resgatar as próprias memórias: "lugares imprecisos", "pontos nebulosos", "ilhas esboçando-se no universo vazio" (RAMOS, 2008, p. 12).

Os capítulos de Infância, porém, não foram escritos na ordem em que figuram no livro. De acordo com os manuscritos do autor, que podem ser encontrados no Arquivo do Instituto de Estudos Brasileiros da Universidade de São Paulo ${ }^{271}$, os primeiros relatos redigidos por Graciliano não são "Nuvens", "Manhã" e "Verão", mas "Samuel Smiles”, “Os astrônomos” e “O menino da mata e seu cão Piloto”, todos datados

\footnotetext{
270 De acordo com Claudio Leitão, autor do posfácio apresentado na 39a edição do livro publicado pela Editora Record, "a concepção e a produção dos relatos abrangem os anos de 1936 a 1944" (LEITÃO, Claudio. "Pósfácio" in RAMOS, 2008, p. 270).

${ }^{271} \mathrm{http}: / /$ www.ieb.usp.br/acervo
} 
de $1938^{272}$. Interessante notar, desse modo, que o autor teria iniciado seu percurso memorialístico resgatando o fio condutor de suas lembranças não pelos acontecimentos cronologicamente mais remotos, mas por episódios centrados nas desilusões e descobertas de uma criança já crescida ${ }^{273}$, e que marcariam, definitivamente, sua entrada no mundo da leitura.

Somente em setembro de 1939 Graciliano escreveria "Nuvens", recuperando no tempo suas lembranças mais antigas. Nesse capítulo, reconhecendo sua incapacidade de precisar aquilo que será relatado - e que aparece de forma nebulosa, como frestas entre nuvens espessas ou "rasgões num tecido negro" -, o narrador declara que a primeira coisa que guardou na memória "foi um vaso de louça vidrada, cheio de pitombas, escondido atrás de uma porta” (RAMOS, 2008, p. 9-11). Em seguida, confessa:

Ignoro onde o vi, quando o vi, e se uma parte do caso remoto não desaguasse noutro posterior, julgá-lo-ia sonho. Talvez nem me recorde bem do vaso: é possível que a imagem, brilhante e esguia, permaneça por eu a ter comunicado a pessoas que a confirmaram. [...] De qualquer modo a aparição deve ter sido real (RAMOS, 2008, p. 9).

Nesse trecho, o uso dos advérbios e de expressões que denotam dúvida "talvez; é possível que; deve ter sido" - vão determinando o tom inicial da narrativa, em que o escritor parece querer se desculpar antecipadamente por memórias incompletas, por sua inaptidão em coligir os fatos na ordem exata, em recriar as cenas com a nitidez e a precisão que almejaria.

Antonio Candido, em ensaio sobre a obra de Graciliano ${ }^{274}$, afirma que "toda biografia de artista contém maior ou menor dose de romance, pois frequentemente ele não consegue pôr-se em contato com a vida sem recriá-la". De acordo com o crítico, Infância pode ser lido como uma obra de ficção, "pois sua fatura convém tanto à

\footnotetext{
272 Samuel Smiles" (18 de outubro), "Os astrônomos" (21 de outubro) e "O menino da mata e seu cão Piloto" (15 de novembro). "Nuvens" é de 14/09/1939; "Manhã", de 24/11/1940 e "Verão", de $12 / 01 / 1941$.

${ }^{273}$ Em "Os astrônomos", o narrador declara sua idade e sua deficiência: "Aos nove anos, eu era quase analfabeto" (RAMOS, 2008, p. 205).

${ }^{274}$ CANDIDO, Antonio. Ficção e confissão: ensaios sobre Graciliano Ramos. 3. ed. Rio de Janeiro, Ouro sobre Azul, 2006, p. 70.
} 
exposição da verdade quanto da vida imaginária". Segundo Candido, no romance "as pessoas parecem personagens e o escritor se aproxima delas por meio da interpretação literária, situando-as como criações". Apesar disso, é possível perceber "um certo esqueleto de realidade escorando os arrancos da fantasia". E complementa:

Em Infância o esqueleto quase se desfaz, dissolvido pela maneira de narrar, simpática e não objetiva, restando apenas uns pontos de ossificação para nos chamar à realidade. Para o leitor que não conhece a zona do autor, creio que esses pontos não passam de alguns nomes de cidade e de gente (CANDIDO, 2006, p. 70-71, grifo do autor).

Para Walter Benjamin, em ensaio sobre o conceito da História 275 , “a verdadeira imagem do passado perpassa, veloz. 0 passado só se deixa fixar, como imagem que relampeja irreversivelmente, no momento em que é reconhecido". Para o autor, "articular historicamente o passado não significa conhecê-lo como ele de fato foi", mas "apropriar-se de uma reminiscência, tal como ela relampeja no momento de um perigo" (BENJAMIN, 1994b, p. 224; grifos do autor).

Desse modo, é interessante notar em Infância como as descrições iniciais do narrador - tanto dos lugares como das pessoas - constroem-se pelos sentidos e pelas sensações, especialmente as que revelam assombro, medo, deslumbramento.

Da primeira viagem do protagonista, de Quebrangulo, Alagoas, à fazenda, no sertão de Pernambuco, chama a atenção a lembrança de uma escola - que servira de pouso durante o percurso - em que meninos cantavam o abecê em uníssono, tarefa que seria tão árdua mais tarde ao narrador, em seu penoso processo de aprendizado da leitura. Sua família nos é apresentada aos poucos e as pessoas são fragmentadas em partes, descritas inicialmente por meio de mãos, expressões faciais e vozes. Assim surgem o pai e a mãe - "entidades próximas e dominadoras" -, duas irmãs, uma "natural" e outra "legítima", além de personagens que mais tarde apareceriam novamente, compondo o quebra-cabeças da memória: sinha Leopoldina, Amaro vaqueiro, José Baía.

275 BENJAMIN, Walter. "Sobre o conceito da História" in: Magia e técnica, arte e política: ensaios sobre literatura e história da cultura. 7. ed. São Paulo: Brasiliense, 1994b, p. 224. 
O medo aparece descrito assim que o narrador reconstrói as lembranças mais antigas dos pais - "dois seres que me impuseram obediência e respeito" (RAMOS, 2008, p. 15): suas primeiras impressões são de seres "grandes, temerosos e incógnitos". Depois o narrador prende-se a detalhes de cada um: mãos grossas e calosas; mãos finas e transparentes; olhos raivosos, bocas irritadas; riso cavernoso; tempestade e calmaria. A descrição dos pais pelos olhos do narrador revela sua visão de criança pequena, recém-chegada ao mundo:

meu pai e minha mãe conservavam-se grandes, temerosos, incógnitos. Revejo pedaços deles, rugas, olhos raivosos, bocas irritadas e sem lábios, mãos grossas e calosas, finas e leves, transparentes. Ouço pancadas, tiros, pragas, tilintar de esporas, baticum de sapatões no tijolo gasto. Retalhos e sons dispersavam-se. Medo. Foi o medo que me orientou nos primeiros anos, pavor. Depois as mãos finas se afastaram das grossas, lentamente se delinearam dois seres que me impuseram obediência e respeito. Habituei-me a essas mãos, cheguei a gostar delas. Nunca as finas me trataram bem, mas às vezes molhavam-se de lágrimas - e os meus receios esmoreciam. As grossas, muito rudes, abrandavam em certos momentos. 0 vozeirão que as comandava perdia a aspereza, um riso cavernoso estrondava - e os perigos ocultos em todos os recantos fugiam, deixavam em sossego os viventes miúdos: alguns cachorros, um casal de moleques, duas meninas e eu (RAMOS, 2008, p. 14-15).

O assombro com as grandes proporções aparece também na descrição dos lugares: uma "vasta sala", um "pátio imenso", "árvores enormes"276. Um bom exemplo são as impressões do menino sobre a construção do açude na fazenda, uma imagem inicialmente marcada pelo temor, depois pelo fascínio:

Homens cavavam o chão, um buraco se abria, medonho, precipício que me encolhia apavorado entre montanhas erguidas nas bordas. Para que estariam fazendo aquela toca profunda? [...] Retraí-me na admiração

\footnotetext{
276 As expressões "vasta sala", um "pátio enorme", "árvores enormes" referem-se à descrição da escola que serviu como pouso em uma viagem; "pátio imenso" é usado para definir o local onde seria, mais tarde, construído o açude na fazenda ("O pátio, que se desdobrava diante do copiar, era imenso. Julgo que não me atreveria a percorrê-lo. 0 fim dele tocava o céu", p. 14) (RAMOS, G. 2008, p. 10-14).
} 
que me causava o extraordinário formigueiro. As formigas suavam, as camisas brancas tingiam-se, enegreciam, ferramentas cravavam-se na terra, outras jogavam para cima o nevoeiro que formava os morros [...].

O que me pasmou foi o açude, maravilha, água infinita onde patos e marrecos nadavam. Surpreenderam-me essas criaturas capazes de viver no líquido. 0 mundo era complicado. 0 maior volume de água conhecido antes continha-se no bojo de um pote - e aquele enorme vaso metido no chão, coberto de folhas verdes, flores, aves que mergulhavam de cabeça para baixo, desarranjava-me a ciência. Com dificuldade, estabeleci a relação entre o fenômeno singular e a cova fumacenta (RAMOS, 2008, p. 14-15).

Essa noção de pequenez frente às pessoas e ao mundo será novamente vivenciada pelo narrador quando o universo conhecido se alargar e a família partir da fazenda para a vila de Buíque, como já descrevemos no início deste capítulo. Antes disso, porém, as lembranças são voltadas para explorar os extremos e as contradições da vida: de um lado, fartura e beleza; de outro aridez e devastação: "trevas densas e claridades ofuscantes"277. Opostos que se construíam tanto no clima e na vegetação como no humor variável das pessoas com quem o narrador convivia, especialmente os pais; oscilações constantes que o menino, ainda pequeno, não podia compreender:

Bem e mal ainda não existiam, faltava razão para que nos afligissem com pancadas e gritos. Contudo as pancadas e os gritos figuravam na ordem dos acontecimentos, partiam sempre de seres determinados, como a chuva e o sol vinham do céu. E o céu era terrível, e os donos da casa eram fortes. Ora, sucedia que minha mãe abrandava de repente e meu pai, silencioso, explosivo, resolvia contar-me histórias. Admiravame, aceitava a lei nova, ingênuo, admitia que a natureza se houvesse modificado. Fechava-se o doce parêntese - e isto me desorientava (RAMOS, 2008, p. 22).

${ }^{277}$ Capítulo "Manhã". 
Conforme a criança cresce e acomodam-se suas impressões sobre o mundo novo da fazenda, o retrato dos pais torna-se mais nítido na memória do narrador:

\begin{abstract}
Nesse tempo meu pai e minha mãe estavam caracterizados: um homem sério, de testa larga, uma das mais belas testas que já vi, dentes fortes, queixo rijo, fala tremenda; uma senhora enfezada, agressiva, ranzinza, sempre a mexer-se, bossas na cabeça mal protegida por um cabelinho ralo, boca má, olhos maus que em momentos de cólera se inflamavam com um brilho de loucura (RAMOS, 2008, p. 16).
\end{abstract}

Surge ainda a memória da vida marital em que, em consonância, os dois "entes difíceis ajustavam-se":

Na harmonia conjugal a voz dele perdia a violência, tomava inflexões estranhas, balbuciava carícias decentes. Ela se amaciava, arredondava as arestas, afrouxava os dedos que nos batiam no cocuruto, dobrados, e tinham dureza de martelos (RAMOS, 2008, p. 16).

Outras aparições vão sendo resgatadas da memória do menino: o avô materno, "alto, magro, de cabelos e barba como pasta de algodão [...]. Homem de imenso vigor". A avó materna, "grave, ossuda", com "protuberâncias na testa e bugalhos severos". Havia ainda "um casal de bisavós: uma santa morena e encarquilhada, um velhinho autoritário que embirrava com meu pai". O moleque José "começava a revelar-se"; a irmã natural se desenvolvia, "recebendo com frequência arranhões nos melindres" (RAMOS, 2008, p. 24-25).

No capítulo intitulado "Verão", o narrador volta a duvidar da veracidade dos fatos que se formam na teia da sua memória. A seca que tomou conta da fazenda naquela estação certamente foi real, porém o narrador confessa ignorar "se as plantas murchas e negras foram vistas nessa época ou em secas posteriores". Em suas palavras, 
desse antigo verão que me alterou a vida restam ligeiros traços apenas. E nem deles posso afirmar que efetivamente me recorde. 0 hábito me leva a criar um ambiente, imaginar fatos a que atribuo realidade. [...] Certas coisas existem por derivação e associação; repetem-se, impõemse - e, em letra de forma, tomam consistência, ganham raízes. Dificilmente pintaríamos um verão nordestino em que os ramos não estivessem pretos e as cacimbas vazias. Reunimos elementos considerados indispensáveis, jogamos com eles, e se desprezamos alguns, o quadro parece incompleto (RAMOS, 2008, p. 27-28).

Desse episódio, o que ficam são as lembranças de um verão derradeiro, em que os sonhos ruíram como "nuvens de poeira", e as conversas e risos deram lugar a "rostos sombrios e rumores abafados". Faltou água em casa e o menino experimentou pela primeira vez a angústia da sede, ignorando o tempo que teria durado o sofrimento: "a boca enxuta, os beiços gretados, os olhos turvos, queimaduras interiores [...] Em redor os objetos se deformavam, trêmulos. Veio a imobilidade, veio o esquecimento". Também pela primeira vez o narrador via a impotência do pai frente ao poder inclemente da natureza:

Espanto, e enorme, senti ao enxergar meu pai abatido na sala, o gesto lento. Habituara-me a vê-lo grave, silencioso, acumulando energia para gritos medonhos. [...] Meu pai era terrivelmente poderoso, e essencialmente poderoso. Não me ocorria que o poder estivesse fora dele, de repente o abandonasse, deixando-o fraco e normal, um gibão roto sobre a camisa curta (RAMOS, 2008, p. 30-31).

A fraqueza do pai, porém, não poupou o menino da violência doméstica. Era preferencialmente nele - e no moleque José - que o homem rude descontava todo o seu desgosto e sua insatisfação. A insignificância da criança frente ao poder do adulto é o assunto que abordaremos a seguir.

Para Antonio Candido, um dos aspectos mais belos de Infância é a "progressiva descoberta do mundo - das pessoas, das coisas, do bem e do mal, da liberdade peada e da tirania da convenção, às quais se choca, ou se adapta a tenra haste da meninice" (CANDIDO, 2006, p. 122). 
No capítulo "Um cinturão", escrito cronologicamente antes de "Nuvens", "Manhã" e "Verão"278, a imprecisão e a nebulosidade da memória - que dão o tom desses relatos iniciais do livro - cedem lugar a uma narrativa repleta de pormenores e de um sentimento de mágoa e tristeza pautado nem tanto pelas dores do castigo físico, mas, principalmente, pela dor moral.

\subsection{Infância, insignificância e justiça: "como as aranhas que trabalham na telha negra"}

Conforme já discutido no Capítulo 3, em Sobrados e Mucambos, analisando o perfil de uma sociedade patriarcal ${ }^{279}$, Gilberto Freyre esclarece que o domínio do pai na administração da justiça e da família concedia-lhe o direito de castigar não somente os escravos e as "crias da casa", mas também as mulheres e os próprios filhos. Desse modo, lembrando a situação que envolve a violência paterna no trato com o "menino branco", Freyre afirma que

seu corpo era o mais castigado dentro de casa. Depois do corpo do escravo, naturalmente. Depois do corpo do moleque leva-pancada, que às vezes apanhava por ele e pelo menino branco. Mas o menino branco também apanhava (FREYRE, 1996, p. 68).

O autor complementa essa tese, lembrando que a criança era castigada "por uma sociedade de adultos em que o domínio sobre o escravo desenvolvia, junto com as responsabilidades de mando absoluto, o gosto de judiar também com o menino" (FREYRE, 1996, p. 68-69).

278 "Um cinturão", de acordo com os manuscritos, escrito em 01/05/1939.

279 O assunto foi abordado no Capítulo 3, no estudo de Menino de engenho; retomamos aqui pela pertinência do tema. 
Desse modo, é até com certa naturalidade que o narrador de Infância revela desde suas mais tenras memórias o destempero dos adultos em relação às crianças da casa, incluindo os dedos da mãe, "que nos batiam no cocuruto, dobrados, e tinham dureza de martelos" (RAMOS, 2008, p. 17) e a violência do pai, que "não economizava pancadas e repreensões" (p. 31).

De acordo com o narrador, porém, até o "episódio do cinturão", seu martírio limitava-se ao castigo físico, isto é, ao sofrimento do corpo, e desaparecia naturalmente, "quando findava a dor", não deixando mágoas ou rancor. Até as sovas mais duras aplicadas contra o menino eram facilmente perdoadas: "Batiam-me porque podiam bater-me, e isto era natural" (p. 33). A dor física, descrita pelo narrador após uma surra memorável que levou da mãe, pode revelar o tamanho da violência que se exercia contra a criança:

Certa vez minha mãe surrou-me com uma corda nodosa que me pintou as costas de manchas sangrentas. Moído, virando a cabeça com dificuldade, eu distinguia nas costas grandes lanhos vermelhos. Deitaram-me, enrolaram-me em panos molhados com água e sal - e houve uma discussão na família. Minha avó, que nos visitava, condenou o procedimento da filha e esta afligiu-se. Irritada, ferira-me à toa sem querer. Não guardei ódio a minha mãe: o culpado era o nó. Se não fosse ele, a flagelação me haveria causado menor estrago (RAMOS, 2008, p. 33-34).

No capítulo "Um cinturão”, porém, o narrador de Infância relata ter figurado pela primeira vez na qualidade de "réu". Apesar de ter apenas "quatro ou cinco anos", o menino fora julgado e condenado por um crime que não cometera, sem direito a defesa ou a recurso, permitindo-nos uma excelente oportunidade de analisar a infância sob o ângulo da "insignificância". 0 termo é usado pelo próprio narrador, pela primeira vez, para qualificar a irmã recém-nascida: “De repente surgiu a terceira irmã, insignificância, nos braços de sinha Leopoldina" (RAMOS, 2008, p. 15). 
Embora "nebuloso" para o narrador, o episódio do cinturão contém detalhes e percepções que se avolumam conforme o drama se desenvolve, tanto na descrição externa da cena - o que o menino observa - como nas sensações internas do narrador o que o menino experimenta, em termos de medo, ansiedade e apreensão.

Na descrição externa da cena, a sensação de pequenez do menino é construída desde a escolha de adjetivos e advérbios que aumentam aquilo a que o narrador assiste: através dos olhos da criança, vemos o pai dormindo na "rede infinita", "armada na sala enorme", com paredes "extraordinariamente afastadas". O mau humor paterno ao despertar fez com que o filho naturalmente se refugiasse, amedrontado. Na descrição das sensações internas, o menino revela o terror que já tomara conta daquele ser indefeso, que parecia adivinhar o que estava por vir:

Meu pai dormia na rede armada na sala enorme. Tudo é nebuloso. Paredes extraordinariamente afastadas, rede infinita, os armadores longe, e meu pai acordando, levantando-se de mau humor, batendo com os chinelos no chão, a cara enferrujada. Naturalmente não me lembro da ferrugem, das rugas, da voz áspera, do tempo que ele consumiu rosnando uma exigência. Sei que estava bastante zangado, e isto me trouxe a covardia habitual. Desejei vê-lo dirigir-se a minha mãe e a José Baía, pessoas grandes, que não levavam pancada. Tentei ansiosamente fixar-me nessa esperança frágil. A força do meu pai encontraria resistência e gastar-se-ia em palavras. Débil e ignorante, incapaz de conversa ou defesa, fui encolher-me num canto, para lá dos caixões verdes. Se o pavor não me segurasse, tentaria escapulir-me: pela porta da frente chegaria ao açude, pela do corredor acharia o pé de turco. Devo ter pensado nisso, imóvel, atrás dos caixões. Só queria que minha mãe, sinha Leopoldina, Amaro e José Baía surgissem de repente, me livrassem daquele perigo (RAMOS, 2008, p. 34).

Para a infelicidade do narrador, ninguém se interpôs no caminho entre o adulto e a criança para amenizar a cólera paterna. Ao descobrir o filho escondido, o pai o inquiriu severamente sobre o paradeiro de um cinturão, atribuindo-lhe culpa pelo desaparecimento da peça. As falhas da memória infantil resultam em suposições do que talvez tenha ocorrido: "imagino os berros do meu pai"; "provavelmente fui sacudido". Porém traumas daquele episódio perdurariam por toda a vida adulta do narrador: 
Situações deste gênero constituíram as maiores torturas da minha infância, e as consequências delas me acompanharam. [...] Hoje não posso ouvir uma pessoa falar alto. 0 coração bate-me forte, desanima, como se fosse parar, a voz emperra, a vista escurece, uma cólera doida agita coisas adormecidas cá dentro. A horrível sensação de que me furam os tímpanos com pontas de ferro (RAMOS, 2008, p. 35).

Durante o interrogatório sobre o cinturão, o menino emudece. A infância naturalmente sem voz - torna-se ainda mais silenciosa. Na condição de réu, em um tribunal em que a única palavra que se ouvia era a da promotoria e da acusação, sem direito a jurados, advogado de defesa ou juiz, o menino de "quatro ou cinco anos" sucumbe perante a cólera do pai:

Onde estava o cinturão? Eu não sabia, mas era difícil explicar-me: atrapalhava-me, gaguejava, embrutecido, sem atinar com o motivo da raiva. Os modos brutais, coléricos, atavam-me: os sons duros morriam, desprovidos de significação. [...] 0 assombro gelava-me o sangue, escancarava-me os olhos. Onde estava o cinturão? Impossível responder. Ainda que tivesse escondido o infame objeto, emudeceria, tão apavorado que me achava. [...] 0 homem não me perguntava se eu tinha guardado a infame correia: ordenava que a entregasse imediatamente. Os seus gritos me entravam na cabeça, nunca ninguém se esgoelou de semelhante maneira [...] Onde estava o cinturão? A pergunta repisada ficou-me na lembrança: parece que foi pregada a martelo (RAMOS, 2008, p. 34-35).

Após a feroz e intensa arguição, o menino apega-se novamente à ilusão de que o acaso poderia salvá-lo: a chegada de alguém na sala, a transferência da fúria para um ser de insignificância ainda maior - os cachorros ou o moleque José -, a aparição de um adulto, qualquer coisa a lhe livrar do martírio que estava por vir: a condenação. Em seu pensamento, um instante de esperança: 
A fúria louca ia aumentar, causar-me sério desgosto. Conservar-me-ia ali desmaiado, encolhido, movendo os dedos frios, os beiços trêmulos e silenciosos. Se o moleque José ou um cachorro entrasse na sala, talvez as pancadas se transferissem. O moleque e os cachorros eram inocentes, mas não se tratava disto. Responsabilizando qualquer um deles, meu pai me esqueceria, deixar-me-ia fugir, esconder-me na beira do açude ou no quintal. Minha mãe, José Baía, Amaro, sinha Leopoldina, o moleque e os cachorros da fazenda abandonaram-me (RAMOS, 2008, p. 35-36).

Porém enquanto pensava em uma possível salvação, o menino não percebeu os movimentos do pai; não o viu aproximar-se do torno e pegar o chicote. 0 julgamento estava concluído: considerado culpado, ao réu cabia cumprir sua sentença e sem direito a apelação. 0 castigo seria imediato: uma surra de chicote. Porém, para o filho, por mais que a dor da carne açoitada fosse grande, a dureza da fala e do olhar do pai durante a inquisição tinha sido um martírio ainda pior:

A mão cabeluda prendeu-me, arrastou-me para o meio da sala, a folha de couro fustigou-me as costas. Uivos, alarido inútil, estertor. Já então eu devia saber que rogos e adulações exasperavam o algoz. Nenhum socorro. José Baía, meu amigo, um pobre-diabo. [...] Junto de mim, um homem furioso, segurando-me um braço, açoitando-me. [...] 0 suplício durou bastante, mas, por muito prolongado que tenha sido, não igualava a mortificação da fase preparatória: o olho duro a magnetizarme, os gestos ameaçadores, a voz rouca a mastigar uma interrogação incompreensível (RAMOS, 2008, p. 36-37).

Durante a descrição da surra que levara, entre os dois parágrafos em que se constroem o tempo e o espaço da narrativa, o pensamento do narrador desloca-se para descrever o lugar ermo e sombrio em que se encontrava; um lugar chamado "infância", no qual sua voz jamais seria ouvida:

Achava-me num deserto. A casa escura, triste; as pessoas tristes. Penso com horror nesse ermo, recordo-me de cemitérios e de ruínas malassombradas. Cerravam-se as portas e as janelas, do teto negro pendiam teias de aranha. Nos quartos lúgubres minha irmãzinha engatinhava, começava a aprendizagem dolorosa (RAMOS, 2008, p. 36). 
Terminado o acesso de fúria do pai, e com ele, o castigo, o menino injuriado foi esconder-se perto dos caixões, gemendo baixinho e lamentando-se das feridas. Do seu canto na sala, antes de adormecer, pôde ver o pai dirigir-se novamente à rede para deitar-se, onde encontrou o "maldito cinturão", que provavelmente se desprendera enquanto ele dormia.

A descoberta do cinturão na rede comprovava de uma só vez a inocência do menino e a dupla falta do pai, tanto no papel de promotor, acusando-o indevidamente, como no de juiz e carrasco, traduzido no julgamento impiedoso e no castigo cruel. Estando a injustiça definitivamente evidenciada, caberia aos olhos da criança um reconhecimento de culpa, um pedido de perdão, uma palavra sincera de arrependimento frente ao fato probatório. Porém nada disso aconteceu. Embora o narrador afirme ter notado uma ponta de dúvida na atitude do pai ao levantar-se da rede com o cinturão nas mãos - "tive a impressão de que ia falar-me" -, o juiz não entendeu ser necessário reparar o erro, ou reconsiderar a decisão. A infância voltava ao seu grau de insignificância e pequenez, "como as aranhas que trabalham na telha negra":

\begin{abstract}
Pareceu-me que a figura imponente minguava - e a minha desgraça diminuiu. Se meu pai se tivesse chegado a mim, eu o teria recebido sem o arrepio que a presença dele sempre me deu. Não se aproximou: conservou-se longe, rondando, inquieto. Depois se afastou. Sozinho, vio de novo cruel e forte, sobrando, espumando. E ali permaneci, miúdo, insignificante, tão insignificante e miúdo como as aranhas que trabalhavam na telha negra. Foi esse o primeiro contato que tive com a justiça (RAMOS, 2008, p. 37).
\end{abstract}

O tema da justiça frente à insignificância humana volta a ser explorado por Graciliano Ramos no capítulo “O moleque José"280, escrito quase três anos após "Um cinturão"281, no qual o narrador, porém, vive um papel diferente: o de algoz. Nesse capítulo, o protagonista revisita o sentimento de inveja que nutria pelo menino negro, "agregado da casa", companheiro de aventuras na sua meninice, e relata com pormenores o episódio que lhe teria marcado "a carne e o espírito". Antes de estabelecer os fatos, descreve o moleque como "uma insignificante mancha trêmula" (RAMOS, 2008, p. 86-88).

\footnotetext{
${ }^{280}$ Capítulo "O moleque José” (RAMOS, 2008, p. 85-91).

281 “Um cinturão", datado de 1ำ de maio de 1939; "O moleque José", de 5 de fevereiro de 1942.
} 
Neto da negra Quitéria ${ }^{282}$, José fora resgatado pelo pai do narrador para não ser vencido pela verminose ou oferecido "como crias de gato" do mesmo modo que ocorrera com seus irmãos. Dócil e ao mesmo tempo sagaz, o moleque conseguia safarse das punições mais severas com humildade e certa dose de malandragem, com promessas não cumpridas juradas "pelas cinco chagas de Nosso Senhor Jesus Cristo". Na definição do narrador, José era "tortuoso, sutil, falava demais, ria constantemente, suave e persuasivo, tentando harmonizar-se com todas as criaturas". Quando repreendido,

baixava a cabeça. Voltava, expunha as suas pequenas habilidades sem se ofender, jeitoso, humilde, os dentes à mostra. Não era alegre. Os olhos brancos ocultavam-se, frios e assustados, os beiços tremiam às vezes, mas isto se disfarçava numa careta engraçada que amolecia a cólera das pessoas grandes. E José se escapulia, escorregava, brado e gelatinoso, das mãos que o queriam agarrar. Apanhado na malandragem, mentia, inocente e sem-vergonha. Juntava os indicadores em cruz, beijava-os [...] Franzino, magrinho, achatava-se. Uma insignificante mancha trêmula (RAMOS, 2008, p. 86).

Apresentando um temperamento bem diferente do moleque, mostrando incapacidade de reagir quando pressionado - como ocorrera no caso do cinturão -, o narrador via em José um exemplo a ser seguido, de não chorar frente às injustiças, de ser submisso e humilde a fim de obter algum benefício próprio. Além disso, o menino não se envergonha em revelar que tomava o moleque por modelo, tentando imitar seu jeito de falar, uma vez que era incapaz de copiar-lhe as ações. Também cobiçava seu conhecimento de mundo e sua esperteza, envergonhando-se quanto à própria estupidez e ignorância, sentindo-se humilhado especialmente quando os garotos se reuniam para tratar de assuntos mundanos, sobre mulheres, e faziam brincadeiras de cunho sexual que ele ainda não compreendia. Talvez por isso o narrador confesse - não sem certa dose de constrangimento - a satisfação que provava ao perceber que José também errava e podia estar sujeito a falhas e enganos.

\footnotetext{
282 Segundo a descrição, escrava que "engendrou vários filhos". Enquanto os machos fugiram e sumiram, as fêmeas, Luísa e Maria, "agregavam-se" à casa. Maria deu continuidade à tradição escrava mesmo após a libertação; teve uma filha, Joaquina, que na falta da mãe a substituiu na cozinha. Já Luísa era considerada pelo narrador "intratável e vagabunda"; aparecia nos momentos de seca para "fomentar a desordem" e "gerar negrinhos", que morriam ainda crianças. 0 moleque José é um dos sobreviventes (RAMOS, 2008, p. 85).
} 
No episódio em que trocou o papel de réu - a que estava habitualmente acostumado - pelo de carrasco, o narrador presenciava uma cena comum: o pai inquiria José sobre algum malfeito. Ao contrário do que se sucedeu no caso do cinturão, porém, não havia no ar "nenhum indício de tempestade e violência", uma vez que a culpa "era leve" e o pai não estava em seu estado colérico: "contentar-se-ia com algumas injúrias" e "disposto a absolver, aceitava facilmente as explicações" (RAMOS, 2008, p. 89). Porém o moleque teimava em mentir, apesar de provas e evidências contra ele, e isso foi arruinando sua tentativa de safar-se ileso. 0 castigo seria aplicado na cozinha, como no caso do cinturão, por meio do chicote. 0 pai arrastou o moleque, que sofreria a pena exemplar pela obstinação em negar o crime. 0 narrador seguiu o réu e o carrasco, "excitado por uma viva sede de justiça". Em suas palavras, não sentia "nenhuma simpatia ao companheiro desgraçado, que se agoniava no pelourinho, aguardando a tortura":

Conservei-me perto da lei, desejando a execução da sentença rigorosa. Não me afligiam receios, porque ninguém me acusava, ninguém me bulia a consciência. Não distinguindo perigos, supunha que eles se haviam dissipado inteiramente (RAMOS, 2008, p. 90).

Assim, não se contentando em observar a execução da pena, quis dela tomar parte como coautor e algoz, procurando auxiliar o pai no castigo do moleque. No entanto, ao perceber as intenções do menino, o pai desiste do castigo a José e conclui a punição transferindo para o próprio filho todas as injúrias, fazendo-o "participar do sofrimento alheio" (RAMOS, 2008, p. 91).

Para Antonio Candido (2006), um dos traços mais constantes presentes em Infância é o "sentimento de humilhação e machucamento":

Humilhação de menino fraco e tímido, maltratado pelos pais e extremamente sensível aos maus-tratos sofridos e presenciados. Por toda parte, recordações doídas de alguma injustiça, de alguma vitória descarada do forte sobre o fraco. Talvez porque ante a sensibilidade do narrador as circunstâncias banais da vida avolumassem como outras tantas brutalidades. [...] E sempre - sempre - a punição é gratuita, 
nascendo daquela desnorteante injustiça com que trava conhecimento certo dia, por causa do cinturão paterno. A consequência natural é o refúgio no mundo interior e o interesse pelos aspectos inofensivos da vida. Inofensivos e, portanto, inúteis. Sonhar, ler, imaginar mundos na escala das baratas (CANDIDO, 2006, p. 71-72).

Também segundo Candido, outra característica presente em toda a obra de Graciliano - tanto na fictícia como na autobiográfica - é a negação "pertinaz dos valores da sociedade e das normas decorrentes" (2006, p. 86). No que se refere a Infância, essa característica revela-se em algumas das suas "experiências fundamentais no conhecimento do mundo", como no caso do cinturão. Para o crítico, uma das experiências mais duras da criança e do adolescente "é o conflito entre a virtude teórica e a conduta como realmente é. Decorrem disso o sentimento de relatividade do bem e das normas em geral", o que resulta na formação de indivíduos "crentes, céticos, conformados ou rebeldes". Para Candido, "Graciliano viveu essa experiência fundamental de maneira dolorosa e se alinhou entre os últimos" (p. 87). Em suas palavras,

o cinturão já famoso na literatura brasileira, que lhe ocasionou o castigo injusto, simboliza as raízes do seu trato com a norma social. Daí lhe parecer gratuita, arbitrária e feita para fazer sofrer. Nem doutro modo avaliou as relações com os pais, a disciplina escolar, o tratamento dispensado aos subordinados e infelizes (CANDIDO, 2006, p. 87).

O capítulo intitulado "Venta-Romba" é um exemplo desse "tratamento dispensado aos infelizes". Sendo um dos últimos episódios escritos por Graciliano ${ }^{283}$, no texto o narrador relembra um triste acontecimento ocorrido em sua casa: a arbitrária prisão de um mendigo conhecido na vila - que tinha por alcunha "Venta-Romba" - e que fora mais uma vítima da supremacia dos "fortes".

283 "Venta-Romba", datado de 30 de maio de 1944, cinco anos após “Um cinturão" (10 de maio de 1939). Apenas dois capítulos seriam escritos depois, "A criança infeliz", de 05/06/1944 e "Seu Ramiro", de 09/06/1944. 
Na introdução ao episódio, o narrador informa o leitor, com certa indignação: "Ofereceram a meu pai o emprego de juiz substituto e ele o aceitou sem nenhum escrúpulo". Em seguida, complementa:

Nada percebia de lei, possuía conhecimentos gerais muito precários. Mas estava aparentado com senhores de engenho, votava na chapa do governo, merecia a confiança do chefe político - e achou-se capaz de julgar (RAMOS, 2008, p. 237).

Para o menino, que sofria em sua própria casa nas mãos de um "juiz" tendencioso e pernóstico - e para isso basta lembrar o caso do cinturão -, a nomeação do pai a um cargo dessa natureza era um disparate, o que se comprovou por meio deste episódio, definido pelo narrador como uma "recordação lastimosa". Antes de relatar o ocorrido no dia em que o mendigo veio à sua casa pedir esmola, porém, o narrador descreve o molambo como um ser "brando", cuja insignificância podia ser notada tanto pela humildade e por seu caráter inofensivo como pelos “andrajos e remendos" que lhe cobriam o corpo:

Humildade serena, insignificância, as mãos trêmulas e engelhadas, os pés disformes arrastando as alpercatas, procurando orientar-se nas esquinas, estacionando junto aos balcões. Restos de felicidade esvaíamse nas feições tranquilas. 0 aió sujo pesava-lhe no ombro; o chapéu de palha esburacado não lhe protegia a cabeça curva; o ceroulão de pano cru, a camisa aberta, de fralda exposta [...] (RAMOS, 2008, p. 238-239).

A descrição de Venta-Romba ultrapassa aquilo que os olhos e os sentidos podem apreender: suas características físicas e vestimentas. 0 narrador interpreta a alma do mendigo e seu estado de espírito; não vê naquele pobre ser senão bondade e simplicidade, restos de uma vida desperdiçada, que dependia unicamente da generosidade alheia para sobreviver: 
A voz corria mansa; as rugas da cara morena se aprofundavam num sorriso constante; o nevoeiro dos olhos se iluminava com estranha doçura. Nunca vi mendigo tão brando. A fome, a seca, noites frias passadas ao relento, a vagabundagem, a solidão, todas as misérias acumuladas num horrível fim de existência haviam produzido aquela paz. Não era resignação. Nem parecia ter consciência dos padecimentos: as dores escorregavam nele sem deixar mossa. [...] Aparecia uma vez por semana, às sextas-feiras, quando se realizava a caridade: um pires de farinha nas casas particulares, um vintém nas lojas e nas bodegas (RAMOS, 2008, p. 238-239).

Porém talvez o maior erro do mendigo tenha sido o de aparecer em hora imprópria, "de supetão", na casa da família, assustando as crianças e as moças. Repelido veementemente pela mãe do narrador, Venta-Romba tenta explicar-se, por meio de seu parco vocabulário, sem obter sucesso. O caso complica-se com a chegada do "juiz substituto", que, sem oferecer ao réu a oportunidade de defender-se ou retirar-se, lhe dá voz de prisão. 0 mendigo, que embora pobre não era desonesto ou criminoso, nem cometera delito grave, não podia acreditar: "Brincadeira de seu major". E, embora consciente do equívoco que cometera, o juiz não pode voltar atrás com sua palavra, com receio de "findar no ridículo" (RAMOS, 2008, p. 241).

"Por quê, seu major?”, perguntava Venta-Romba, querendo entender o motivo da arbitrariedade (p. 241-242). Para o menino, que presenciava a cena, "seu major não saberia manifestar-se":

Assombrara-se, recorrera à força pública e receava contradizer-se. Talvez sentisse compaixão e se reconhecesse injusto. Enraivecia, acusava-se, e despejava a cólera sobre o infeliz, causa do desarranjo. Em desespero, roncou injúrias. O polícia que pigarreava na sala se avizinhou, a blusa desabotoada, faca de ponta à cintura, as reiunas de vaqueta ringindo (RAMOS, 2008, p. 242).

A injustiça cometida pelo pai assombrava o menino, do mesmo modo que ocorrera no caso do cinturão. Para não se desmoralizar perante a família e, neste caso, 
também perante os subordinados, o major - agora juiz - precisava concluir aquilo que começara, dar o exemplo, condenar o réu, mesmo que isso não lhe parecesse o mais justo ou correto. A vida era assim. Mas as perguntas sem respostas ressoavam no interior da criança, enquanto ela testemunhava mais uma violação de direitos, mais um ato arbitrário de força bruta contra um ser fraco e inocente:

Por quê? Como se prendia um vivente incapaz de ação? Venta-Romba movia-se de leve. Não podendo fazer mal, tinha de ser bom. Difícil conduzir aquela bondade trôpega ao cárcere, onde curtiam pena os malfeitores. [...] Venta-Romba sucumbiu, molhou de lágrimas a barba sórdida, extinguiu num murmúrio a pergunta lastimosa. 0 soldado ergueu-lhe a camisa, segurou o cós do ceroulão, empunhou aquela ruína que tropeçava, queria aluir, atravessou o corredor, ganhou a rua (RAMOS, 2008, p. 242).

Para o menino, restou apenas o remorso e a indignação:

Fui postar-me na calçada, sombrio, um aperto no coração. Venta-Romba descia a ladeira aos solavancos, trocando as pernas, desconchavandose como um judas de sábado da Aleluia. [...] Eu experimentava desgosto, repugnância, um vago remorso. Não arriscara uma palavra de misericórdia. Nada obteria com a intervenção, certamente prejudicial, mas devia ter afrontado as consequências dela. Testemunhara uma iniquidade e achava-me cúmplice. Covardia (RAMOS, 2008, p. 243).

Para João Paulo Ayub284, "Venta-Romba" é um dos capítulos "mais desconcertantes de Infância" (2015, p. 16). Segundo o sociólogo, Graciliano apresenta a figura miserável do mendigo como uma "dolorosa trajetória de uma existência insignificante" e, por meio do episódio, o autor alagoano "conta a história de uma palavra negada". De acordo com Ayub,

\footnotetext{
${ }^{284}$ João Paulo Ayub, Doutor em Ciências Sociais - Universidade Federal de Goiás. Pós-doutor em Estudos Literários pela Universidade Federal de Uberlândia (UFU), com experiência nas áreas de Sociologia, Antropologia, Estudos Literários e Ciência Política.
} 
todo o episódio narrado no capítulo intitulado "Venta-Romba" se estrutura em torno do trágico encontro entre o pobre coitado VentaRomba e a mão cega da justiça - ou seria a mão implacável do direito? - encarnada naquele momento pelo pai de Graciliano. Um encontro que deixou perplexa a criança que ainda vive no coração do escritor adulto (AYUB, 2015, p. 17).

O silêncio que se instaurou após a pergunta de Venta-Romba - "Por que, seu major?" - negou ao réu o direito de saber o motivo pelo qual estava sendo preso. Ninguém ousou responder-lhe, apesar de sua insistência. Para Ayub, a resposta à pergunta do mendigo

persiste enquanto questão fundamental que atravessa a memória do escritor. Persiste, ainda, no silêncio que se instaurou no coração da criança, não deixando de constituir-se como uma modalidade da palavra, a palavra que vive em estado de desfalecimento, sentido sufocado. Uma questão que vem de fora, do outro, e que, devido à sua estrangeira procedência, interroga as leis do mesmo e as desestabiliza. Ao contrário daqueles que faziam valer a força da justiça, a sensibilidade do menino não lhe permitiu passar ileso através da infame experiência (AYUB, 2015, p. 16-17).

Ainda para o sociólogo, comentando o episódio com ironia, "a atitude brutal para com o pobre mendigo" não deveria causar espanto, já que Venta-Romba não passava "de um ser desprovido de uma condição social mínima" e, consequentemente, não possuía "a qualidade que o iguala aos demais seres humanos" (2015, p. 18). Porém

para a criança, que diante daquela situação de violência covarde "experimentava desgosto, repugnância, um vago remorso", VentaRomba era ainda um homem. A mestria do escritor está presente, como nunca, na descrição do destino das palavras do mendigo: de um lado, a surdez do poder que o conduz, insensível, ao cárcere; de outro, a dor no peito da criança que assistiu naquelas palavras trôpegas a vaga luz do semblante desolado de um rosto humano (AYUB, 2015, p. 18). 
0 autor complementa, afirmando que "a compreensão da natureza" do mendigo Venta-Romba "exige um esforço do leitor":

\begin{abstract}
é preciso aceitar que estamos - a despeito de uma imensidão de indicações em sentido contrário -, diante de um ser humano que sobrevive nos limites da negação do próprio homem. Seguir o caminho que leva a aceitar a condição desta triste figura nos permitirá encontrar a chave para a compreensão, num âmbito maior, do modo como a palavra, mesmo num estado de desamparo e limitação extremos, resiste e se presta a velar pela humanidade [...]. Venta-Romba, como uma "trouxa de molambos", se movimentava no curtíssimo espaço de sua linguagem minguada, quase incompreensível, murmurante (AYUB, 2015, p. 16).
\end{abstract}

De fato, Venta-Romba tem poucas falas no texto, e em todas elas revela a voz mansa, o jeito brando, submisso: “Como vai, seu major? E a mulher de seu major? Os filhinhos de seu major?". O resto são murmúrios, engasgos, "interjeições roucas e abafadas", lamentos, cochichos, além da questão que fica no ar: "Por que, seu major?". Em vista do silêncio, a pergunta sem resposta incomoda o menino: "era o que eu também desejava saber". Porém mais do que isso, o narrador se revolta com a percepção do próprio silêncio, com sua ausência de atitude, com sua conivência com o crime: "não arriscara uma palavra de misericórdia" (RAMOS, 2008, p. 238-243).

Citando o filósofo franco-lituano Emmanuel Levinas (1906-1995), Ayub lembra que "a justiça é um direito à palavra"285; direito negado ao mendigo pelas autoridades que o prendiam; direito que não fazia parte do cotidiano do menino.

Segundo Antonio Candido (2006), "lendo Infância, concluímos que os livros de Graciliano Ramos se concatenam num sistema literário pessimista. Meninos, rapazes, homens, mulheres; pobres, ricos, miseráveis; inteligentes, cultos, ignorantes - todos obedecem a uma fatalidade cega e má":

\footnotetext{
${ }^{285}$ LEVINAS, Emmanuel. Totalidade e infinito. Lisboa: Edições 70, 1980 APUD AYUB, João Paulo. "VentaRomba' e o silêncio da palavra negada: a escuta das margens em Infância, de Graciliano Ramos" in e-scrita. Revista do Curso de Letras da UNIABEU Nilópolis, v.6, N. 1, jan-abr, 2015, p. 14-23.
} 
a vida é um mecanismo de negaças em que procuramos atenuar o peso inevitável dessas fatalidades: e parecemos ridículos, maus, inconsequentes. Às vezes somos fortes e pensamos esmagar a vida; na realidade, esmagamos apenas os outros homens e acabamos esmagados por ela. [...] 0 narrador de Infância se encarrega de nos ensinar algumas das razões dessa cadeia necessária de sofrimentos. Os castigos imerecidos, as maldades sem motivo, de que são vítimas os fracos, estão na base da organização do mundo (CANDIDO, 2006, p. 7576).

Dessa forma, a infância se mantém no lado da balança em que figuram os fracos, os pobres e oprimidos. Venta-Romba, o moleque José, o próprio narrador: todos marcados pela pequenez e pela insignificância, como as "aranhas que trabalham na telha negra”.

Para Candido, essa "filosofia de vida" característica dos romances de Graciliano "não é nova nem brilhante", mas "isso não importa". Nas palavras do crítico, "um artista nada mais faz do que tomar os lugares-comuns e renová-los pela criação" (CANDIDO, 2006, p. 76). 


\subsection{0 barão de Macaúbas e a mosca que caiu no fogo}

Em sua dissertação de mestrado em que estudou a arte literária de Graciliano Ramos em duas versões - adulta e infantil 286 -, o escritor Ricardo Ramos Filho ${ }^{287}$ referese à infância do avô da seguinte maneira:

O mais provável é que o autor alagoano tenha sido uma criança solitária, que não recebeu assim tanta atenção, pois rapidamente teve que disputar espaço com os irmãos mais novos que iam nascendo. Em 1895 seu pai, que era comerciante, decidiu criar gado no sertão e mudou-se com a família para a vila de Buíque, em Pernambuco, onde morava o avô do escritor pelo lado materno, o coronel Pedro Ferreira Ferro. Foram viver em uma fazenda chamada Pintadinho, no meio da caatinga. Foi lá que o menino começou a descobrir as coisas (RAMOS FILHO, 2013, p. 36).

A "descoberta das coisas" a que se refere o autor passa pela descoberta da linguagem. 0 narrador de Infância revela logo no primeiro capítulo do livro sua intrínseca relação com a oralidade e com a sonoridade da língua: o recitar do abecê na escola rural, as onomatopeias e cantigas de José Baía, os versos da epopeia de dona Maria $^{288}$. Mais tarde, o menino ainda se mostraria interessado pelo sotaque e pela fala natural do moleque José, que lhe preenchiam o pensamento com frases ou expressões curiosas que, descontextualizadas, desproviam-se de significado e formavam combinações de palavras que se sustentavam apenas pela brincadeira sonora: "Seu Ferreira de gibão/no cavalo de seu Afro" (RAMOS, 2008, p. 88) 289.

286 RAMOS FILHO, Ricardo de Medeiros. Arte literária em dois ramos "graciliânicos": adulto e infantil. São Paulo, USP, 2013. [DISSERTAÇÃo], 117p. Em sua dissertação de mestrado, Ricardo Ramos Filho estuda as obras São Bernardo (adulta) e A terra dos meninos pelados (infantil), em percurso comparativo.

287 Neto de Graciliano Ramos e filho do também escritor Ricardo Ramos (1929-1992), Ricardo Ramos Filho (1954) não conheceu o avô, que falecera um ano antes do seu nascimento.

${ }^{288}$ Citações do capítulo "Nuvens".

${ }^{289}$ Nessa passagem de "O moleque José", o narrador conta como aproveitou uma simples fala do moleque para recriá-la em versos que podiam ser falados ou cantados (RAMOS, 2008, p. 88). 
Para Ramos Filho, "muito do que se concretiza em escritura é fruto de experiências vividas e transformadas" (RAMOS FILHO, 2013, p. 33). Assim, ao analisar o processo criativo do escritor alagoano, o autor entende que as histórias folclóricas e as cantigas do sertão "povoaram a imaginação do menino Graciliano”, formando um substrato que, mais tarde, seria usado em suas próprias narrativas:

Fica fácil perceber que está na oralidade o primeiro interesse de Graciliano Ramos pelas histórias. Esses contos ouvidos provavelmente aguçaram os seus sentidos e chamaram sua atenção, colocando-o afetivamente em contato com a possibilidade de, mais tarde, escrever seus próprios textos (RAMOS FILHO, 2013, p. 37).

Nas narrativas de Infância, porém, contrapondo-se justamente à ludicidade com que o menino descobria a linguagem oral, apresenta-se o duro, massacrante e penoso aprendizado da linguagem escrita:

[...] ia-me pouco a pouco entorpecendo, a cabeça inclinava-se, os braços esmoreciam - e, entre bocejos e cochilos, gemia a cantiga fastidiosa que Mocinha sussurrava junto a mim. Queria agitar-me e despertar. 0 sono era forte, enjoo enorme tapava-me os ouvidos, prendia-me a fala. $\mathrm{E}$ as coisas em redor mergulhavam na escuridão, as ideias se imobilizavam. De fato eu compreendia, ronceiro, as histórias de Trancoso. Eram fáceis. O que me obrigavam a decorar parecia-me insensato (RAMOS, 2008, p. 111-112).

Para Ramos Filho, o caminho trilhado pelo menino Graciliano no aprendizado da leitura não foi nada fácil. E "a dificuldade ganhou sentido particular no livro do Barão de Macaúbas, onde o escritor iniciou suas leituras", ao ser introduzido a "dois contos que lhe pareceram estranhos" tanto pela linguagem apresentada pelos personagens como pela temática abordada: passarinhos que davam conselhos e uma mosca desobediente que acabava caindo no fogo (RAMOS FILHO, 2013, p. 39). O próprio Graciliano atribui a esse livro, senão a única, uma das principais causas de sua repulsa inicial à leitura: "o maior culpado foi ele" (RAMOS, 2008, p. 128). 
Porém as dificuldades para o menino começaram de fato antes mesmo de seu primeiro contato com o barão de Macaúbas e de sua entrada na escola. Foi no aprendizado das primeiras letras com uma antiga carta de $\mathrm{ABC}$ e tendo o próprio pai como professor que o narrador experimentou suas primeiras e amargas lições de leitura.

A descrição da carta de ABC (Figura 3) aparece duas vezes - e de forma bastante semelhante - nos escritos de Graciliano: tanto em Infância (no capítulo "Leitura") como em uma crônica publicada em abril de 1938, pouco antes, portanto, do início da redação dos relatos que, compilados mais tarde, comporiam seu livro de memórias.

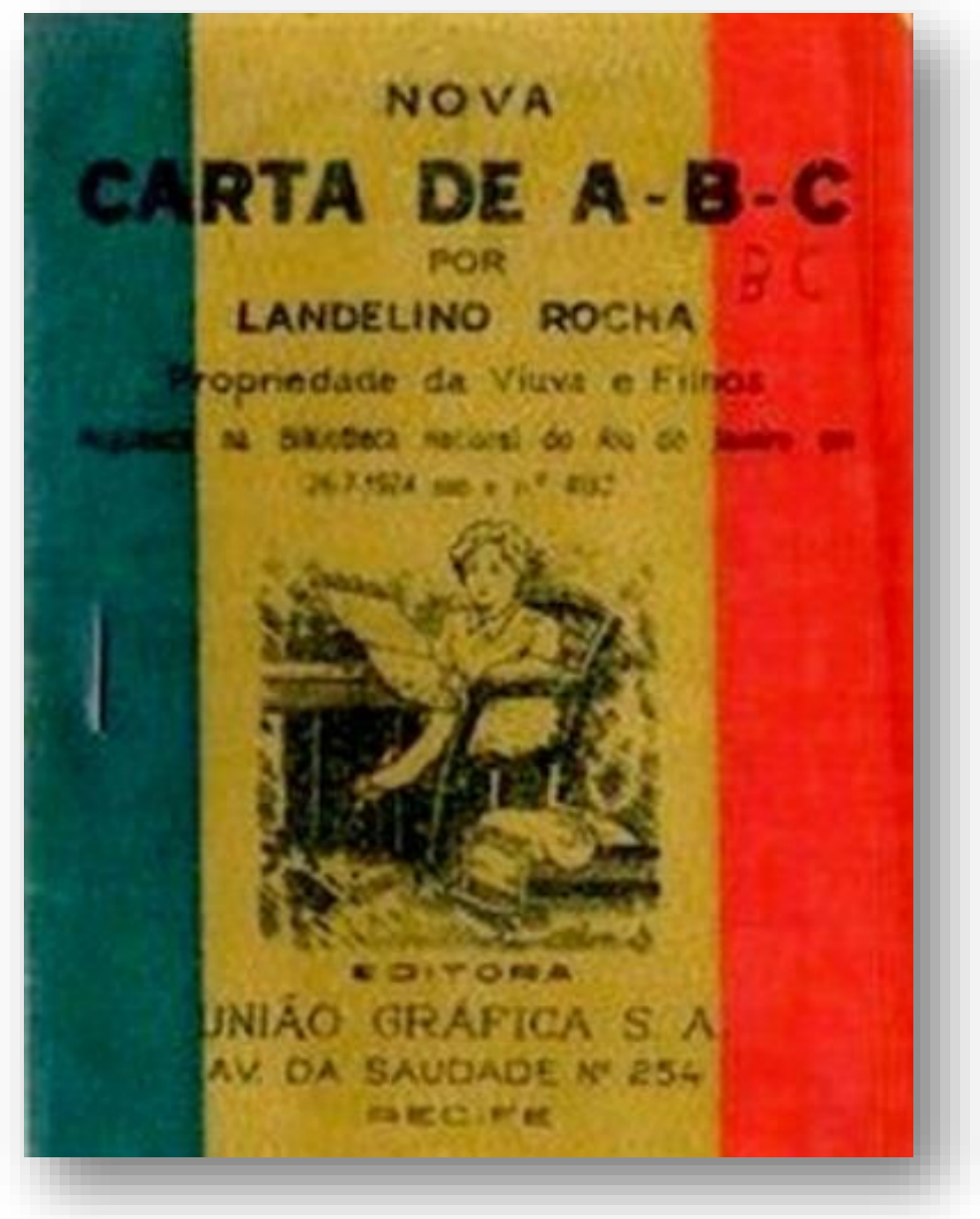

FIGURA 3 - Imagem da Carta de ABC com as três listas verticais a que se refere Graciliano Ramos no livro Infância e na crônica "Um novo ABC". 
Intitulada "O novo ABC"290, a crônica traz à tona as recordações do autor acerca de suas experiências infantis com a chamada "carta de leitura". No texto, ele compara o antigo instrumento com a nova carta ilustrada, recebida "dias antes" das mãos de um amigo. É deste modo que o escritor se refere à antiga cartilha:

Aquela velha carta do $\mathrm{ABC}$ dava arrepios. Três faixas verticais borravam a capa, duras, antipáticas; e, fugindo a elas, encontrávamos num papel de embrulho o alfabeto, sílabas, frases soltas e afinal máximas sisudas. Suportávamos esses horrores como um castigo e inutilizávamos as folhas percorridas, esperando sempre que as coisas melhorassem.

Engano: as letras eram pequeninas e feias; o exercício da soletração, cantado, embrutecia a gente; os provérbios, os graves conselhos morais ficavam impenetráveis, apesar dos esforços dos mestres arreliados, dos puxavantes de orelhas e da palmatória" (RAMOS, 2005, p. 248).

Uma das "máximas sisudas" contidas na antiga cartilha era: "A preguiça é a chave da pobreza". Para o autor, o texto em linguagem figurada era mais uma entre as coisas incompreensíveis que as crianças - "uns pirralhos bastante desgraçados" que não conheciam outras chaves senão as que abriam portas, gavetas e armários - eram obrigadas a repetir sem entender.

Na crônica, Graciliano cita outro ditado popular comum na época, contido na última página da cartilha: "Fala pouco e bem; ter-te-ão por alguém". Para o autor, que não compreendia a mesóclise e nem o sentido implícito no abstrato conceito, "Terteão" era um homem e a frase, totalmente descabida e sem nexo.

A confusão do menino com a expressão também é narrada em Infância, nos capítulos intitulados "Leitura" e "Escola", que resumem as primeiras dificuldades da criança no aprendizado das primeiras letras ${ }^{291}$ com a tal "carta do ABC".

\footnotetext{
${ }^{290}$ A crônica "Um novo ABC" está publicada na coletânea Linhas tortas (Rio de Janeiro, Record, 2005).

2910 autor dedica vários capítulos para relatar o penoso processo de alfabetização, entre eles: "Leitura", "Escola”, "D. Maria", "O barão de Macaúbas, "Um novo professor", "Os astrônomos", "Samuel Smiles" e "O menino da mata e o seu cão Piloto".
} 
Descoberta por acaso pelo menino na venda do pai, a velha cartilha foi descrita pelo narrador de Infância como "uns cadernos de capa enfeitada por três faixas verticais, borrões, nódoas cobertas de riscos semelhantes aos dos jornais e dos livros" (RAMOS, 2008, p. 109). O protagonista relata seus primeiros contatos com a leitura como "uma ideia infeliz" em uma "manhã funesta":

Meu pai tentou avivar-me a curiosidade valorizando com energia as linhas mal impressas, falhadas, antipáticas. Afirmou que as pessoas familiarizadas com elas dispunham de armas terríveis. Isso me pareceu absurdo: os traços insignificantes não tinham feição perigosa de armas. Ouvi os louvores, incrédulo (RAMOS, 2008, p. 109).

Já na descrição das primeiras aulas, ministradas pelo próprio pai, aparecem termos como "escravidão imposta" e "tarefa odiosa", além de o aprendiz revelar o instrumento de punição física que aguardava ansiosamente suas falhas para exercer sua função:

Meu pai não tinha vocação para o ensino, mas quis meter-me o alfabeto na cabeça. Resisti, ele teimou - e o resultado foi um desastre. Cedo revelou impaciência e assustou-me. Atirava rápido meia dúzia de letras, ia jogar solo. À tarde pegava um côvado, levava-me para a sala de visitas - e a lição era tempestuosa. Se não visse o côvado, eu ainda poderia dizer alguma coisa. Vendo-o, calava-me. Um pedaço de madeira, negro, pesado, da largura de quatro dedos (RAMOS, 2008, p. 111).

Para Gilberto Freyre, no que se refere à autoridade do pai sobre o filho em uma sociedade patriarcal,

a administração da justiça pelo patriarca sobre a própria família, a autoridade exercida pelo adulto sobre o párvulo, no interesse real ou ostensivo da educação, ou da moralização do menino, não há dúvida que tomou muitas vezes o caráter francamente sádico [...]. Sadismo, que apenas se atenuou ao estender-se o sistema patriarcal das casasgrandes aos sobrados das cidades, onde os velhos continuaram a reinar sobre os moços de modo quase absoluto (FREYRE, 1996, p. 70). 
Essa "pedagogia sádica" seria ainda exportada para o sistema educacional: "os pais autorizavam mestres e padres a exercerem sobre os meninos o poder patriarcal de castigá-los com a vara de marmelo e a palmatória" (FREYRE, 1996, p. 70)292.

Relatos de castigos físicos ligados à educação não são raros na literatura. Em narrativas do final do século XIX e início do século XX que têm a escola como pano de fundo, como é o caso de Conto de escola (Machado de Assis, 1884), O Ateneu (Raul Pompeia, 1888), e Doidinho (José Lins do Rego, 1933), por exemplo, há profusão de cenas em que os mestres fazem uso frequente da humilhação pública ou de instrumentos de tortura - como a palmatória e a vara de marmelo - para corrigir tanto os alunos preguiçosos, desatentos ou malfeitores como aqueles que eram incapazes de aprender uma lição.

Em Infância, não foi preciso que o pai delegasse ao professor ou ao padre a tarefa de punir o estudante fracassado. Ele mesmo cuidou que o pequeno aprendiz fosse bem castigado e repreendido perante seu desastroso desempenho frente as primeiras letras. Em seus relatos, o narrador afirma ter continuado a temer as aulas com o inábil professor, mesmo depois de aprendido o alfabeto: "Sozinho, não me embaraçava, mas na presença de meu pai emudecia. [...] As pobres mãos inchavam, as palmas vermelhas, arroxeadas, os dedos grossos mal se movendo" (RAMOS, 2008, p. 112-113). A mágoa do menino pelo doloroso aprendizado revela-se em várias descrições:

As três manchas verticais, úmidas de lágrimas, estiravam-se junto à mão doída, as letras renitentes iriam afligir-me dia e noite, sempre. As réstias que passeavam no tijolo e subiam a parede marcavam a aproximação do suplício. Dentro de algumas horas, de alguns minutos, a cena terrível se reproduziria: berros, cólera imensa a envolver-me, aniquilar-me, destruir os últimos vestígios de consciência, e o pedaço de madeira a martelar a carne machucada (RAMOS, 2008, p. 113-114).

Tendo desistido o pai da árdua e inútil tarefa, coube a Mocinha ${ }^{293}$ a missão de continuar ensinando o pequeno. É com ela que o narrador tem o primeiro contato com a máxima: “Fala pouco e bem, ter-te-ão por alguém”, citada por Graciliano na crônica. 0

${ }^{292}$ Conforme já citado (Capítulo 3, página 113).

${ }^{293}$ Mocinha, a "irmã natural" do narrador. 
narrador questiona a irmã: “Mocinha, quem é o Terteão?”. Mocinha não sabia; o menino ficaria sem a resposta (RAMOS, 2008, p. 114). Ao findar a leitura da carta, o papel ordinário se decompôs, manchando os dedos do menino de tinta. Esperava-se agora o primeiro livro e o início do aprendizado formal, na escola ${ }^{294}$. Porém mesmo no estabelecimento de ensino os disparates contidos na carta do $\mathrm{ABC}$ voltam a assombrar a criança:

Os fragmentos da carta de $\mathrm{ABC}$, pulverizados, atirados ao quintal, dançavam-me diante dos olhos. "A preguiça é a chave da pobreza. Fala pouco e bem, ter-te-ão por alguém [...]”. Quem era Terteão? Um homem desconhecido. Iria o professor mandar-me explicar Terteão e a chave? (RAMOS, 2008, p. 114).

As tensões iniciais, no entanto, logo dão lugar a uma brandura ainda não conhecida: entra em cena a figura da professora, Dona Maria, "a voz mansa", "a mão curta", muito diferente da brutalidade a que o menino estava acostumado: na avaliação do narrador, até o cheiro dela era bom! 0 aluno novato se espantava com tanta paciência e serenidade. Com ajuda da professora, venceu - não sem uma boa dose de sacrifício os primeiros desafios de leitura na escola. E logo chegou em casa o bilhete em que se pedia um segundo livro para o menino avançar nos estudos: "meu pai manifestou surpresa com espalhafato"; "houve uma aragem de otimismo, chegaram-me "retalhos de felicidade" (RAMOS, 2008, p. 128).

A chegada do novo livro, porém, imediatamente desencorajou a criança. Mesmo sem se dar conta do conteúdo que o aguardava no "grosso volume feio e escuro", a forma do livro já assustava o leitor iniciante: "cartonagem severa"; na folha de rosto, um "retrato barbudo e antipático"; nas "folhas delgadas, incontáveis, as letras fervilhavam, miúdas, e as ilustrações avultavam num papel brilhante como rasto de lesma ou catarro seco". O narrador complementa: "Ericei-me, pressenti que não sairia boa coisa dali" (RAMOS, 2008, p. 128-129)295.

\footnotetext{
${ }^{294}$ A entrada do menino no primeiro estabelecimento de ensino é narrada no capítulo "Escola". ${ }^{295}$ As descrições do livro de leitura encontram-se no final do capítulo "D. Maria" e no início de "O barão de Macaúbas".
} 
Citando pesquisa da autora Marcia Cabral da Silva, sobre a formação do leitor no Brasil, Ramos Filho revela que,

na escola onde estão as lembranças de Graciliano Ramos, quando se concluía o estudo da cartilha, material com a finalidade específica de ensinar e decodificar letras, sílabas e palavras, introduzia-se uma sequência de livros de leitura, cujo conteúdo versava sobre os mais variados assuntos - da formação do universo aos hábitos de higiene (RAMOS FILHO, 2013, p. 37).

O autor complementa, citando, nesse rol, o livro do barão de Macaúbas:

A figura de Abílio César Borges, o Barão de Macaúbas, é emblemática deste tipo de produção, tendo marcado a história da leitura pedagógica no Brasil com edições que conheceram verdadeiro sucesso, conforme se infere da observação do prólogo da 65 a edição de 1890. Considerando-se a data da primeira edição, estima-se um ritmo médio de sete reedições a cada dois anos (RAMOS FILHO, 2013, p. 37-38).

Em estudo intitulado Livros solicitados para a infância escolar: Província de Goiás (Século XIX), cujo intuito foi mapear materiais impressos publicados para as crianças que frequentavam a escola primária daquela época e região, as autoras Diane Valdez, Ana Flávia Rodrigues e Wanessa Andrade de Oliveira ${ }^{296}$, especialistas em educação, afirmam que

a literatura é uma excelente fonte para desvendar e conhecer, não somente os livros que circulavam na região, como também a relação dos leitores com os livros. Os apontamentos indicam relações diversas, como ritos de passagens na descoberta da leitura, relações de sofrimento, de ódio, de curiosidade e tantos outros sentimentos que merece um estudo mais aprofundado (VALDEZ, RODRIGUES \& OLIVEIRA, 2011, s/p).

\footnotetext{
296 Pesquisadoras da Faculdade de Educação da Universidade Federal de Goiás (UFG). A obra do barão de Macaúbas foi tema de Doutorado de Diane Valdez (VALDEZ, D. A representação de infância nas propostas pedagógicas do Dr. Abilio Cesar Borges: o barão de Macahubas. UFG, 2006).
} 
Em sua pesquisa, as autoras apontam os livros de Abílio César Borges ${ }^{297}$ entre os mais solicitados nas listas escolares e atribuem como uma das possíveis causas desse "sucesso editorial" o fato de o próprio autor distribuir gratuitamente suas obras para inúmeras províncias do Brasil, além de não haver no mercado brasileiro "um número expressivo de obras escolares para crianças" (VALDEZ, RODRIGUES \& OLIVEIRA, 2011, $\mathrm{s} / \mathrm{p})$.

Porém o autor não seria lembrado apenas pelas obras que publicou, mas também por ter ocupado um importante papel na educação brasileira no final do século XIX. De acordo com Diane Valdez, que estudou em sua tese de doutorado as representações da infância nas obras de Abílio Borges, o barão de Macaúbas investiu, a partir de 1858, em um ambicioso projeto como proprietário e diretor de colégios privados, implementando "o modelo de instrução que achava ideal, iniciando sua produção de livros escolares e publicando um vasto material que divulgava suas iniciativas consideradas inovadoras"298. A autora atribui ainda seu reconhecimento público e a larga divulgação de suas ideias ao fato de Abilio ter recebido do próprio Imperador Pedro II o título de "pedagogo do império" (VALDEZ, 2006, p. 82-83).

No entanto, é interessante notar uma controvérsia no que se refere à figura do barão: embora na descrição de Valdez, Abílio tenha sido "defensor de uma pedagogia baseada no ensino amorável e livre de castigos físicos", "semeador de ideias inovadoras no campo de instrução da infância" (VALDEZ, p. 170), na literatura acaba sendo representado de forma bastante diversa, uma vez que é no barão de Macaúbas que Raul Pompeia $^{299}$ se inspira para criar o personagem Aristarco Argolo dos Ramos, diretor do internato na obra $O$ Ateneu (1888), figura considerada a própria personificação do autoritarismo e da vaidade (Figura 4).

\footnotetext{
${ }^{297}$ Abílio Cesar Borges, o barão de Macaúbas (1856-1891).

298 "Inaugurou em Salvador, em 1858, o Ginásio Baiano e, no ano de 1870, transferiu-se para o Rio de Janeiro com o Colégio Abilio da Corte, que dirigiu até 1879. Em 1881, criou seu novo Colégio Abilio na cidade de Barbacena, em Minas Gerais, dirigindo-o até 1888, quando retornou ao Rio de Janeiro com o Novo Colégio Abilio, inaugurado em parceria com seus filhos que, desde 1883, já dirigiam o estabelecimento" (VALDEZ, 2006, p. 82-83).

299 Raul Pompeia (1863-1895) estudou no Colégio Abílio da Corte, que tinha na época como diretor o barão de Macaúbas em pessoa - o personagem Aristarco teria sido inspirado na figura do barão (VALDEZ, 2006; ZILBERMAN, 2012).
} 


\section{Para Valdez,}

contrariando a prática do ensino amoroso e moderno propagado pelo diretor e por outros, no ano de 1888, Raul Pompéia, ex-aluno do Colégio Abilio da Corte, publicou $O$ Ateneu: crônica de saudades, romance autobiográfico inspirado em sua experiência como aluno interno neste estabelecimento. 0 destaque desta obra é para o papel do temido 'Mestre Aristarco', proprietário e diretor do Ateneu, um personagem autoritário, egocêntrico e vaidoso, que fazia claramente alusão a Abilio (VALDEZ, 2006, p. 182).

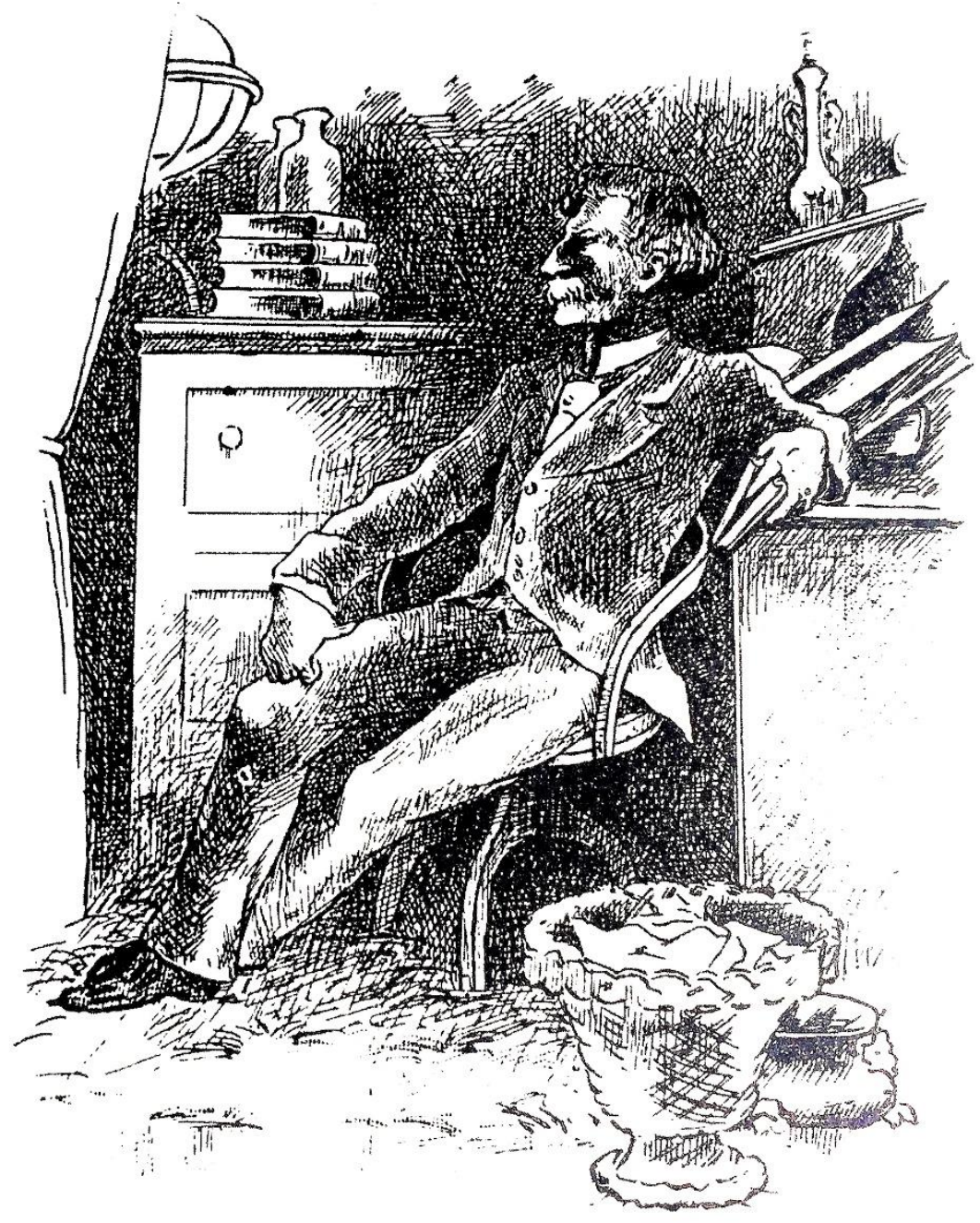

FIGURA 4 - Reprodução da ilustração original de Raul Pompeia para o Diretor do Ateneu, Aristarco Argolo de Ramos, figura inspirada em Abilio Borges, o "barão de Macaúbas" (In: POMPEIA, 2015, p. 45) 
Em estudo de Regina Zilberman sobre a relação entre o escritor de $O$ Ateneu e o barão de Macaúbas, a autora afirma que, por meio da ficção, "a crítica de Pompeia não visava atingir apenas o educador baiano, mas o sistema escolar brasileiro de seu tempo" (ZILBERMAN, 2012, p. 38). Além disso, Abílio Borges teria a seu favor outros importantes admiradores, como o poeta Castro Alves ${ }^{300}$, por exemplo, que também estudou em um de seus estabelecimentos de ensino (p. 40-42). Ainda segundo Zilberman, os livros didáticos de Abílio foram "continuamente reeditados" e nem mesmo a Proclamação da República impediu que o "velho Barão de Macaúbas" continuasse a oferecer "seu conhecido material didático, agora adaptado aos novos tempos" (p. 43).

E é uma de suas obras - o Segundo livro de leitura para uso das escolas brasileiras (Figura 5) - que cai nas mãos do narrador de Infância e ganha um capítulo especial, além de citações isoladas em outras passagens do romance.

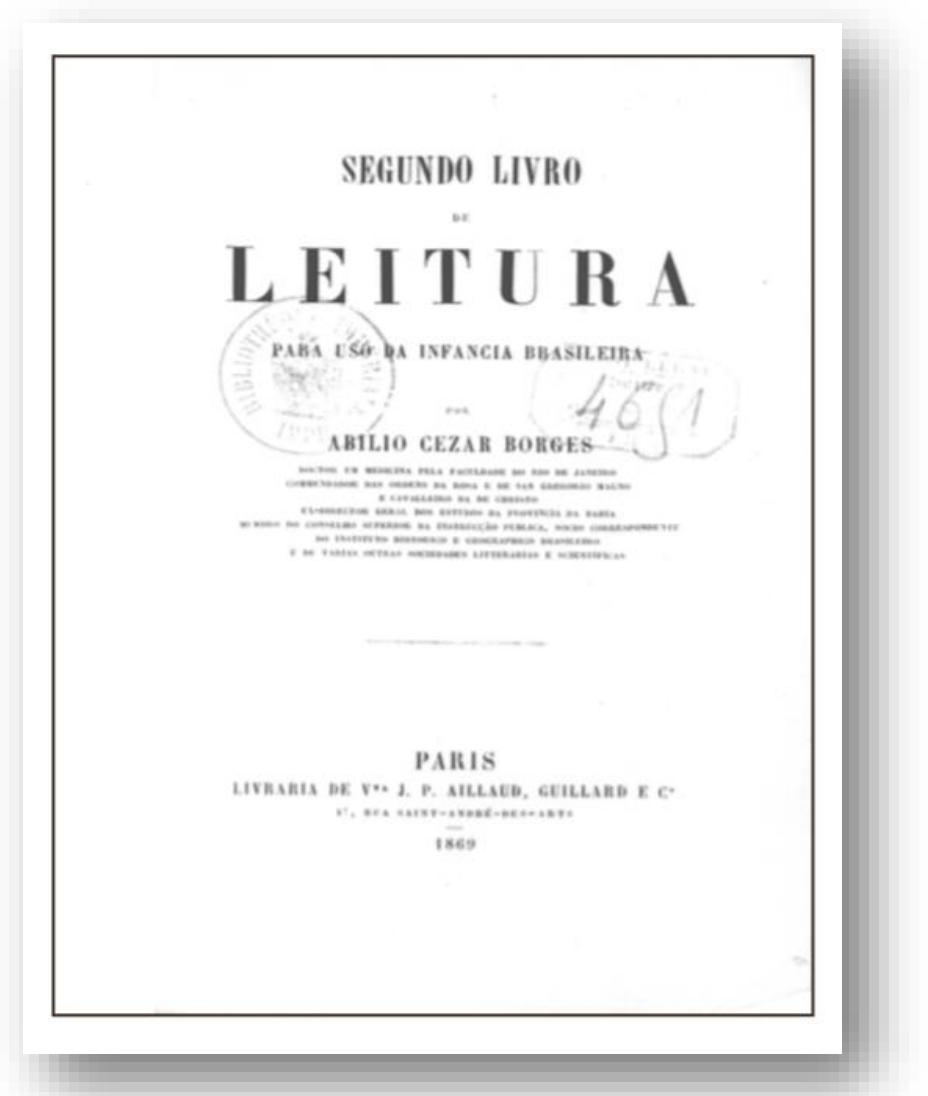

FIGURA 5 - Capa do Segundo Livro de Leitura "para uso da infância brasileira", por Abilio Cezar Borges, o barão de Macaúbas. Publicado em Paris (1869) ${ }^{301}$

\footnotetext{
300 Castro Alves (1847-1871) estudou no Ginásio Baiano, cujo Diretor era o Sr. Abílio Cesar Borges. O poeta chegou a escrever versos em homenagem a ele.

301 Fonte e foto: Biblioteca Nacional da França apud VALDEZ, 2006, p. 215.
} 
Logo no princípio do capítulo o menino revela toda a sua frustração com o novo livro: "Principiei a leitura de má vontade. E logo emperrei na história de um menino vadio que, dirigindo-se à escola, se retardava a conversar com os passarinhos e recebia deles opiniões sisudas e bons conselhos" (RAMOS, 2008, p. 129). Incomodavam o leitor iniciante a linguagem artificial e os "adjetivos colhidos no dicionário" usados para embelezar a forma como os personagens se expressavam, bem diferente da oralidade a que o menino estava habituado: "Passarinho, queres tu brincar comigo?". Também não lhe fazia sentido a moralidade contida nas histórias, em que inocentes personagens eram punidos no final por não acatarem regras, como a pobre mosca que, "desobedecendo às ordens maternas, tanto voou que afinal caiu no fogo" (RAMOS, 2008, p. 129-130). Nas suas reminiscências, o narrador questiona tanto o talento (ou a falta de talento) como as intenções do tal barão:

\begin{abstract}
Examinei-lhe o retrato e assaltaram-me presságios funestos. Um tipo de barbas espessas [...]. Carrancudo, cabeludo. E perverso. Perverso com a mosca inocente e perverso com os leitores. Que levava a personagem barbuda a ingerir-se em negócios de pássaros, de insetos, e de crianças? Nada tinha com esses viventes. 0 que ele intentava era elevar as crianças, os insetos e os pássaros ao nível dos professores. [...] Infelizmente, um doutor, utilizando bichinhos, impunha-nos a linguagem dos doutores. [...] O passarinho, no galho, respondia com preceito e moral. E a mosca usava adjetivos colhidos no dicionário. A figura do barão manchava o frontispício do livro - e a gente percebia que era dele o pedantismo atribuído à mosca e ao passarinho. Ridículo um indivíduo hirsuto e grave, doutor e barão, pipilar conselhos, zumbir admoestações" (RAMOS, 2008, p. 129).
\end{abstract}

A professora, Dona Maria, tentava explicar ao menino o significado das histórias, traduzindo na linguagem oral e em expressões descomplicadas e coloquiais aquilo que estava escrito. A criança não acreditava: "impossível enxergar a narrativa simples nas palavras desarrumadas e compridas" (RAMOS, 2008, p. 131):

Os meus infelizes miolos ferviam, evaporavam-se, transformavam-se em nevoeiro, e nessa neblina flutuavam moscas, aranhas e passarinhos, nomes difíceis, vastas barbas pedagógicas" (RAMOS, 2008, p. 129). 
As dificuldades de leitura do menino não se findam quando ele enfim consegue terminar a penosa leitura do volume. Depois deste, viriam outros. 0 terceiro livro foi definido pelo narrador como "corpulento, origem de calafrios. Papel ordinário, letra safada". Por volta dos sete anos, o menino ainda não conseguia ler: "Todas as frases artificiais" o deixavam "perplexo" (RAMOS, 2008, p. 132-133). Para complementar os estudos, lhe ofereceram Camões:

Sim senhor: Camões, em medonhos caracteres borrados - e manuscritos. Aos sete anos, no interior do Nordeste, ignorante da minha língua, fui compelido a adivinhar, em língua estranha, as filhas do Mondego, a linda Inês, as armas e os barões assinalados. Um desses barões era provavelmente o de Macaúbas, o dos passarinhos, da mosca, da teia de aranha, da pontuação. Deus me perdoe. Abominei Camões. E ao barão de Macaúbas associei Vasco da Gama, Afonso de Albuquerque, o gigante Adamastor, barão também, decerto (RAMOS, 2008, p. 133).

O narrador retoma o tema sobre o aprendizado da leitura no capítulo intitulado "Os astrônomos". Escrito cronologicamente anos antes de "Leitura", "Escola", e “O barão de Macaúbas”302, em Infância o episódio figura em seu terço final.

É notória a baixa autoestima do narrador na introdução do capítulo, quando ele se compara a outros meninos da sua idade, os vizinhos Mota Lima:

Esses garotos, felizes, para mim eram perfeitos: andavam limpos, riam alto, frequentavam escola decente e possuíam máquinas que rodavam na calçada como trens. Eu vestia roupas ordinárias, usava tamancos, enlameava-me no quintal, engenhando bonecos de barro, falava pouco (RAMOS, 2008, p. 205).

302 "Os astrônomos" é o segundo episódio escrito por Graciliano, na ordem cronológica em que foram publicados como contos isolados, datado de outubro de 1938. "Leitura", "Escola" e "O barão de Macaúbas" datam de 1942. 
O menino acrescenta à imagem negativa sobre si mesmo o fato de não saber ler, mesmo com idade avançada: "Aos nove anos eu era quase um analfabeto" (RAMOS, 2008, p. 205). Para ele, a escola era um lugar de suplício, "uma crucificação":

Não há prisão pior que uma escola primária do interior. A imobilidade e a insensibilidade me aterraram. Abandonei os cadernos [...], não deixei que as moscas me comessem. Assim, aos nove anos ainda não sabia ler (RAMOS, 2008, p. 206).

É nesse ponto que entra novamente a figura do pai, agora não mais com aquela colérica impaciência inicial ou o côvado como inseparável companheiro, na tentativa de lhe ensinar as primeiras letras na carta do $\mathrm{ABC}$, que infligira à criança pequena memoráveis feridas, tanto nas mãos como no orgulho. Era com inesperada surpresa que o leitor balbuciante experimentava conhecer uma face oculta de seu primeiro professor, quando uma noite, após o café, o pai lhe pedira para pegar um livro em sua cabeceira e, com ele, compartilhar a leitura. Não sem profunda apreensão o menino atendera a ordem do pai e iniciara seu suplício, lendo em voz alta, já imaginando uma severa punição. No entanto, para espanto do narrador, o pai interrompera a leitura no meio do capítulo para conversar com o filho, perguntando-lhe se compreendia aquilo que lia. Explicou "que se tratava de uma história, um romance, exigiu atenção e resumiu a parte já lida". Traduziu "em linguagem de cozinha diversas expressões literárias". Nos dizeres do menino, "uma luzinha quase imperceptível surgia longe, apagava-se, ressurgia, vacilante, nas trevas do meu espírito" (RAMOS, 2008, p. 206).

Embora o pai não tenha dado continuidade à tarefa que iniciara aquela noite, o fato de haver escolhido um livro de aventura, em que lobos, fugitivos e lenhadores instigavam a imaginação da criança, trouxe um alento ao pequeno leitor que só conhecia no texto escrito "letras safadas", máximas sem nexo e contos morais. 0 romance de aventura - desprovido de qualquer cunho didático ou moralista - foi capaz de despertar a natural curiosidade da criança pelas histórias, tornando a possibilidade de decifrar o que estava escrito uma tarefa que, de repente, passava a ter significado. 
Com a recusa do pai em continuar auxiliando-o na leitura, o menino recorre a Emília, prima que já dominava essa arte. Mais do que ajudar a desvendar os mistérios da leitura, porém, a menina incentiva o primo a arriscar-se na leitura e a construir pouco a pouco sua independência e autonomia. Para isso, apresenta-lhe os astrônomos, "indivíduos que liam o céu":

\begin{abstract}
Ora, se eles enxergavam coisas tão distantes, por que não conseguiria eu adivinhar a página aberta diante dos meus olhos? Não distinguia as letras? Não sabia reuni-las e formar palavras? Matutei na lembrança de Emília. Eu, os astrônomos, que doidice! Ler as coisas do céu, quem havia de supor? E tomei coragem, fui esconder-me no quintal, com os lobos, o homem, a mulher, os pequenos, a tempestade na floresta, a cabana do lenhador. Reli as folhas já percorridas. $\mathrm{E}$ as partes que se esclareciam derramavam escassa luz sobre os pontos obscuros. Personagens diminutas cresciam, vagarosamente me penetravam a inteligência espessa (RAMOS, 2008, p. 209-210).
\end{abstract}

Na análise desses cinco capítulos em que o autor discorre sobre o aprendizado da leitura ${ }^{303}$, é interessante notar que não foram os castigos físicos, os contos morais ou a carta do $\mathrm{ABC}$ que fizeram com que o menino aprendesse a ler. Foi a boa vontade de Mocinha, a paciência e a persistência de Dona Maria, a ajuda de Emília, e até o incentivo tardio do pai que despertaram na criança a curiosidade pelo desconhecido; curiosidade esta que, uma vez instalada, não abandona o leitor, aparecendo novamente relatada no capítulo "O menino da mata e seu cão Piloto"304.

Para Ramos Filho, a "mediação ocupa sempre papel importante na formação de um leitor". Questionando até que ponto era possível ao menino Graciliano, "enfrentando todas as dificuldades de seu tempo [...] encontrar prazer na leitura" (RAMOS FILHO, 2013, p. 38), o autor também se refere à importância dos mediadores na infância de Graciliano, destacando de forma especial o tabelião Jerônimo Barreto:

\footnotetext{
${ }^{303}$ Referimo-nos aos capítulos "Leitura", "Escola", "D. Maria" "O barão de Macaúbas" e "Os astrônomos". ${ }^{304}$ No capítulo, o menino se depara com uma brochura amarela, um "livro excomungado, escrito por um sujeito ruim, protestante, para enganar os tolos" (RAMOS, 2008, p. 218-219). Embora tivesse muita vontade de ler a história, após o aviso da prima Emília de que se tratava de um livro impuro, o menino desiste da leitura.
} 
A figura de Jerônimo Barreto torna-se [...] essencial. É por suas mãos e pelo contato com os volumes de suas coleções que o menino tem acesso ao Guarani, de José de Alencar, uma das primeiras referências de livros lidos feita pelo escritor alagoano. Algumas de suas leituras iniciais foram indicadas pelo tabelião como aparece explicitamente em Infância (RAMOS FILHO, 2013, p. 40).

É justamente no capítulo "Jerônimo Barreto" que o narrador confessa o desespero que o assolou algum tempo depois de terminado o romance dos lobos e dos fugitivos, quando, tendo finalmente aprendido a ler, tinha dificuldade em encontrar bons livros:

Eu precisava ler, não os compêndios escolares, insossos, mas aventuras, justiça, amor, vinganças, coisas até então desconhecidas. Em falta disso, agarrava-me a jornais e almanaques, decifrava as efemérides e anedotas das folhinhas. Esses retalhos me excitavam o desejo, que ia se transformando em ideia fixa (RAMOS, 2008, p. 229).

Mais uma vez o narrador pede a ajuda de sua prima Emília, mas é o tabelião que abre as portas da sua biblioteca para o pequeno leitor, apresentando-o a clássicos de José de Alencar, Joaquim Manuel de Macedo, Júlio Verne, entre outros: "a existência comum se distanciava e deformava; conhecidos e transeuntes ganhavam caracteres das personagens do folhetim [...] Em poucos meses li a biblioteca de Jerônimo Barreto. Mudei hábitos e linguagem" (RAMOS, 2008, p. 234-235).

De fato a iniciação literária do menino modifica radicalmente seus hábitos e sua linguagem: "Minha mãe notou as modificações com impaciência. E Jovino Xavier também se impacientou [...]" (RAMOS, 2008, p. 235). De acordo com Ramos Filho, “com apenas doze anos de idade" Graciliano fundaria com seu primo Cícero Vasconcelos um periódico chamado $O$ Dilúculo, revelando, assim, desde muito cedo, sua vocação para a escrita (2013, p. 40). 
Para Marcelo Magalhães Bulhões ${ }^{305}$, em estudo em que analisa as funções da metalinguagem no texto literário de Graciliano Ramos, "o advento da leitura de obras de ficção influi sensivelmente no cotidiano do garoto" (BULHÕES, 1999, p. 43):

a leitura de romances passa a interferir em várias atividades de sua vida, de sua personalidade, participando com ele tanto das solicitações escolares quanto das transformações de seu corpo, das perturbações da adolescência, o despertar de sua sexualidade (BULHÕES, 1999, p. 43).

Desse modo, embora penoso e doloroso, o processo de alfabetização e de letramento do narrador de Infância não somente se conclui de modo satisfatório como revela um leitor voraz que, mais tarde, se tornaria um escritor dos mais importantes da nossa história, cuja obra nos surpreende e encanta até hoje, quase um século depois de sua estreia na literatura. E a figura de Jerônimo Barreto para o menino Graciliano pode ser analogicamente comparada ao papel que o Padre Cabral desempenhou para o menino grapiúna ${ }^{306}$. Estavam definitivamente abertas para o narrador de Infância as portas do mundo.

${ }^{305}$ Marcelo Magalhães Bulhões, Livre-docente pela UNESP, doutor em Literatura Brasileira e mestre em Teoria Literária e Literatura Comparada (USP).

306 Conforme visto no Capítulo 4, em que estudamos a obra de Jorge Amado, também o autor baiano foi seduzido para o mundo da leitura tardiamente, por meio do incentivo do Padre Cabral, jesuíta português que descobriu o talento do menino e lhe ofereceu os livros de sua estante. 


\subsection{Fabiano, o menino mais velho e o narrador de Infância: elos e conexões entre memória e criação}

Para o poeta José Paulo Paes, em prefácio ao livro Cartas de amor a Heloísa, em que estão compiladas sete cartas escritas por Graciliano entre 16 de janeiro e 8 de fevereiro de 1928 à então noiva, Heloísa Medeiros ${ }^{307}$,

o escritor não é todo o homem, mas uma de suas virtualidades. No caso de Graciliano Ramos, a mais rica sem dúvida, a julgar pela excelência e pela permanência das suas criações". 308

Infância é uma obra surpreendente. A cada leitura, descobrem-se diferentes nuances, sutilezas em detalhes não percebidos anteriormente; fatos correlacionados, fios que tecem linhas invisíveis para que os fragmentos da memória ganhem suporte e se mostrem de forma lúcida e coerente, ainda que os caminhos sejam insidiosos e recobertos de névoa. Sem dúvida é um livro que faz jus ao que diz o poeta paulista sobre o autor alagoano, no que se refere à excelência e à permanência de suas criações. E quando se compara a tessitura do livro de memórias aos temas e enredos de seus outros romances, diferentes relações se estabelecem: uma teia de personagens, fatos e acontecimentos se engendra, revelando conexões entre memória e criação, difíceis de serem dissociadas.

Desse modo, sem pretender esgotar um universo investigativo tão vasto e instigador, propusemo-nos, para encerrar este capítulo, estabelecer certos pontos de contato que revelam interessantes elos entre o livro de memórias de Graciliano Ramos e um de seus romances mais lidos e estudados: Vidas secas ${ }^{309}$. Para isso, deste último

\footnotetext{
307 De acordo com o prefácio escrito por José Paulo Paes, Graciliano conheceu Heloísa Medeiros no Natal de 1927, e com ela se casou menos de dois meses mais tarde, em 16 de fevereiro de 1928. Graciliano, já pai de quatro filhos do primeiro casamento, tem com Heloísa mais quatro, e com ela permanece casado até o fim de sua vida.

308 PAES, J.P. “Amor/humor por via postal” In: RAMOS, G. Cartas de amor a Heloísa. 3. ed. Rio de Janeiro, Record, 1996, p. 23 (grifo do autor).

${ }^{309}$ Vidas secas (1938), quarto romance de Graciliano, publicado após Caetés (1933), São Bernardo (1934) e Angústia (1936). (RAMOS, Graciliano. Vidas secas. 128. ed. Rio de Janeiro, Record, 2015).
} 
analisamos especialmente os capítulos intitulados "Cadeia”, "O menino mais velho" e "Festa".

Entre os fragmentos de memória que conscientemente ou não o autor alagoano selecionou para compor Infância, três assuntos chamam a atenção pela prevalência com que aparecem na narrativa: as reflexões do menino quanto às contradições da vida, suas constatações quanto à insignificância da criança e dos oprimidos frente ao poder e à autoridade dos fortes, e suas confidências sobre os tortuosos caminhos no aprendizado da leitura. Assim, tomando como mote os três principais temas discutidos neste capítulo - infância, justiça e linguagem -, analisaremos como esses assuntos aparecem no romance Vidas secas, em passagens que se referem principalmente a dois dos personagens centrais do livro: Fabiano e seu filho mais velho ${ }^{310}$.

É interessante ressaltar que, embora o intervalo entre a publicação de Vidas secas (1938) e Infância (1945) seja de sete anos, os primeiros capítulos do livro de memórias começaram a ser compostos no mesmo ano do lançamento do romance ${ }^{311}$. E assim como em Infância, também em Vidas secas alguns capítulos foram escritos e publicados como episódios separados (CANDIDO, 2006, p. 121) sendo "Baleia” o relato inicial, seguido por "Sinha Vitória” e “Cadeia”312.

A passagem de Vidas Secas que analisaremos a seguir está inserida no capítulo “Cadeia”, e apresenta algumas interessantes intersecções com o livro de memórias. Nesse capítulo, uma das descrições do soldado amarelo lembra a imagem do pai do narrador em Infância: “a cara enferrujada, uma ruga na testa” (RAMOS, 2015, p. 30). A semelhança se estabelece por meio da expressão "cara enferrujada", usada pelos narradores de ambas as obras tanto para descrever o policial como o genitor, respectivamente. Já o relato da prisão arbitrária de Fabiano pelo soldado nos remete à cena presenciada pelo menino e descrita no capítulo "Venta-Romba". Encarcerado

\footnotetext{
310 No livro, a família é composta por Fabiano, sinha Vitória, o menino mais velho e o menino mais novo crianças apresentadas sem idade nem nome; apenas com essas designações -, além da cachorra Baleia que acompanha a família em sua jornada pelo sertão.

311 Conforme já citamos, de acordo com os manuscritos, os primeiros capítulos de Infância datam de 1938.

312 Em carta de Graciliano datada de maio de 1937 à Heloísa, ele conta à mulher sobre o conto que escreveu: "Escrevi um conto sobre a morte duma cachorra, um troço difícil, como você vê: procurei adivinhar o que se passa na alma de uma cachorra. Será que há mesmo alma em cachorro? Não me importo. 0 meu bicho morre desejando acordar num mundo cheio de preás". O conto seria mais tarde integrado a Vidas secas.
} 
injustamente, tal como o mendigo de Infância, o sertanejo sentia na pele o poder dos fortes e opressores contra os pobres e fracos:

\begin{abstract}
Fabiano marchou desorientado, entrou na cadeia, ouviu sem compreender uma acusação medonha e não se defendeu [...] caiu de joelhos, repetidamente uma lâmina de facão bateu-lhe no peito, outra nas costas. Em seguida abriram uma porta, deram-lhe um safanão que o arremessou para as trevas do cárcere. [...] Por que tinham feito aquilo? Era o que não podia saber. Pessoa de bons costumes, sim senhor, nunca fora preso. De repente um fuzuê sem motivo. Achava-se tão perturbado que nem acreditava naquela desgraça [...] Então por que um semvergonha desordeiro se arrelia, bota-se um cabra na cadeia, dá-se pancada nele? Sabia perfeitamente que era assim, acostumara-se a todas as violências, a todas as injustiças (RAMOS, 2015, p. 31).
\end{abstract}

"Por que tinham feito aquilo?" (RAMOS, 2015, p. 31) "Por que, seu major?" (RAMOS, 2008, p. 238-243). Eram perguntas vazias que ninguém ousava responder. Tinham feito aquilo porque podiam fazer. "Batiam-me porque podiam bater-me" (RAMOS, 2008, p. 33). A vida era assim: de um lado os que podem, e fazem. De outro os que não podem e se submetem. A infância pendia sempre para esse segundo lado da balança. Nas palavras do narrador ${ }^{313}$ de Vidas Secas, os filhos de Fabiano "eram uns brutos, como o pai. Quando crescessem, guardariam as reses de um patrão invisível, seriam pisados, maltratados, machucados por um soldado amarelo" (RAMOS, 2015, p. $37)$.

Outro tema recorrente em Vidas secas que pode ser equiparado às experiências narradas pelo protagonista de Infância é a dificuldade de comunicação dos personagens. Tanto Fabiano como seu filho mais velho apresentam sérias deficiências com relação à elaboração da linguagem, como se pode depreender dos excertos abaixo, retirados dos capítulos “Cadeia” e "0 menino mais velho”, respectivamente:

\footnotetext{
${ }^{313}$ Embora Vidas secas apresente um narrador em terceira pessoa, muitas vezes a fala do narrador mesclase ao discurso indireto livre, revelando pensamentos dos personagens.
} 
Fabiano [...] não sabia falar. Às vezes largava nomes arrevesados, por embromação. Via perfeitamente que tudo era besteira. Não podia arrumar o que tinha no interior. Se pudesse... Ah! Se pudesse, atacaria os soldados amarelos que espancam as criaturas inofensivas (RAMOS, 2015, p. 36).

O pequeno sentou-se, acomodou nas pernas a cabeça da cachorra, pôsse a contara-lhe baixinho uma história. Tinha um vocabulário tão minguado como o do papagaio que morrera no tempo da seca. Valia-se, pois, de exclamações e de gestos [...]. Como não sabia falar direito, o menino balbuciava expressões complicadas, repetia as sílabas, imitava os berros dos animais, o barulho do vento, o som dos galhos que rangiam na catinga, roçando-se (RAMOS, 2015, p. 57-59).

É interessante notar, em ambos os casos, que a ausência de habilidade para o discurso oral está diretamente relacionada a uma punição corporal e a uma sujeição a um ser capaz de exercer um melhor domínio sobre a linguagem. Por não saber se explicar direito ao soldado amarelo, Fabiano fora espancado e preso. Por não aceitar o significado da palavra "inferno", o filho mais velho levou um cocorote da mãe.

Em Infância, no já mencionado capítulo "Chegada à vila”, o menino narrador confessa seu embaraço com as palavras estranhas e enigmáticas, sentindo falta da linguagem conhecida, simples e acessível de José Baía (RAMOS, 2008, p. 46). Em Vidas secas Fabiano admira ao mesmo tempo que teme as palavras "compridas e difíceis da gente da cidade", tentando "reproduzir algumas em vão" e achando-as "inúteis e talvez perigosas" (RAMOS, 2015, p. 20). Mas não só ele e o filho mais velho, como toda a família de Fabiano apresentava uma grande inabilidade para a comunicação oral. 0 papagaio usado como alimento na viagem pelo sertão era "mudo e inútil". De acordo com o narrador, "não podia deixar de ser mudo. Ordinariamente a família falava pouco. [...] viviam todos calados, raramente soltavam palavras curtas". Por isso o papagaio latia, imitando o som da cachorra (RAMOS, 2015, p. 12).

O emudecimento também faz parte da vida do narrador de Infância. Tanto no caso do cinturão e no episódio que envolveu o mendigo Venta-Romba, quanto em outras passagens do livro, o protagonista demonstra total ausência de fala frente à autoridade 
paterna. Além disso, percebe-se sua inibição e seu desconcerto também perante os colegas e meninos da sua idade, e até mesmo em companhia do moleque José, que, na opinião do narrador, sabia usar melhor as palavras do que ele.

Apesar da dificuldade para se expressar, o narrador de Infância revela curiosidade com a sonoridade da língua e com o aprendizado de palavras novas. Um exemplo é o interesse que demonstra pelo termo "inferno", que aparece no capítulo homônimo ${ }^{314}$. Nesse episódio, o menino, que tinha ouvido a palavra e ficara intrigado, vai em busca de seu significado, em conversa com a mãe:

Minha mãe estranhou a curiosidade: impossível um menino de seis anos, em idade de entrar na escola, ignorar aquilo. Realmente eu possuía noções. 0 inferno era um nome feio, que não devíamos pronunciar (RAMOS, 2008, p. 79-80).

Não convencido com as explicações sobre ser o inferno um lugar de fogueiras e demônios de rabo e chifres, o menino questiona as fontes do conhecimento materno: “A senhora esteve lá?” (RAMOS, 2008, p. 81). Diante da insistência do filho, a mãe reafirma o que disse, exaltando a sabedoria dos padres e dos livros, mas nenhum dos argumentos oferecidos satisfaz ao menino. Irritada, ela coloca um ponto final na conversa lhe dando "várias chineladas".

Por situação semelhante passa o menino mais velho, em Vidas Secas. 0 narrador relata que, na véspera do episódio contido no sexto capítulo do livro ${ }^{315}$, o menino ouvira o termo "inferno". Achando a palavra esquisita, porém bonita, ficara curioso para atribuir-lhe um significado: queria "que a palavra virasse coisa" (RAMOS, 2015, p. 57). Após tentativa frustrada de conseguir o significado do termo com o pai, recorreu à mãe para tentar entender o vocábulo: "Sinha Vitória falou em espetos quentes e fogueiras". Assim como o protagonista de Infância, a criança duvida: "A senhora viu?". Achando a pergunta descabida e o menino, insolente, a mãe zangou-se e “aplicou-lhe um cocorote" (RAMOS, 2015, p. 56). Indignado, o menino divaga:

\footnotetext{
${ }^{314}$ Capítulo "O inferno". Manuscrito de 1942.
}

${ }^{315}$ Capítulo "O menino mais velho". 
Não acreditava que um nome tão bonito servisse para designar coisa ruim. E resolvera discutir com Sinha Vitória. Se ela houvesse dito que tinha ido ao inferno, bem. Sinha Vitória impunha-se, autoridade visível e poderosa. Se houvesse feito menção de qualquer autoridade invisível e mais poderosa, muito bem. Mas tentara convencê-lo dando-lhe um cocorote, e isto lhe parecia absurdo (RAMOS, 2008, p. 79-80).

Nos dois episódios citados, tanto em Infância como em Vidas secas, a curiosidade natural da criança é "premiada" com castigos físicos: chineladas e cocorotes. E nas duas obras os personagens infantis parecem entender e aceitar naturalmente a violência gratuita dos pais. 0 menino mais velho de Vidas secas "achava as pancadas naturais quando as pessoas grandes se zangavam, pensava até que a zanga delas era a causa única dos cascudos e puxavantes de orelhas" (RAMOS, 2015, p. 59). 0 narrador de Infância conforma-se: "Batiam-me porque podiam bater-me, e isto era natural” (RAMOS, 2008, p. 33).

Ambos os meninos aprenderam a fazer "a leitura" dos pais antes de se dirigirem a eles. No caso acima descrito, o narrador de Infância inicia a descrição da cena relatando o bom humor da mãe:

Às vezes minha mãe perdia as arestas e a dureza, animava-se, quase se embelezava. Catorze ou quinze anos mais moço que ela, habituei-me, nessas tréguas curtas e valiosas, a julgá-la criança, uma companheira de gênio variável, que era necessário tratar cautelosamente (RAMOS, 2008, p. 79).

Foi num desses dias de trégua que o menino se arriscou a perguntar sobre o inferno. Em Vidas secas, o menino mais velho também aproveitou um instante de calmaria para aproximar-se da mãe em busca de uma explicação para o vocábulo: "animara-se a interrogar sinha Vitória porque ela estava bem disposta" (RAMOS, 2015, 
p. 59-60). Em ambos os casos o final não foi aquele que as crianças esperavam. 0 menino de Vidas secas acabou procurando consolo e compreensão com a cachorra Baleia. Já ao narrador de Infância, restou o ressentimento e a convicção de que nem sempre vale a pena falar o que se pensa:

Não me convenci. Conservei-me dócil, tentando acomodar-me às esquisitices alheias. Mas algumas vezes fui sincero, idiotamente. E vieram-me chineladas e outros castigos oportunos (RAMOS, 2008, p. 83).

Outras passagens poderiam ser citadas como intersecções entre as duas obras, como, por exemplo, os episódios em que tanto o narrador de Infância como Fabiano precisam trocar os trajes confortáveis a que estavam acostumados por roupas de viagem e de festa, respectivamente ${ }^{316}$. Porém o que procuramos mostrar, com essa breve análise comparativa entre Infância e Vidas secas, foram alguns exemplos de intertextualidade entre uma obra memorialística e uma obra ficcional de um mesmo autor, reiterando o que disseram anteriormente Aderaldo Castello e Antonio Candido.

Para Castello, “todo romancista é um memorialista, no sentido em que o romance é a libertação de um estado interior profundo, soma de experiências observadas e vividas” (1966, p. 84). Já para Candido, “toda biografia de artista contém maior ou menor dose de romance, pois frequentemente ele não consegue pôr-se em contato com a vida sem recriá-la" (2006, p. 70).

Para Celdon Fritzen e Gladir da Silva Cabral ${ }^{317}$, em estudo sobre o gênero autobiográfico318, "não se deve esquecer que escrever sobre si é escrever sobre um

\footnotetext{
316 Os episódios situam-se nos capítulos "Chegada à Vila" (Infância) e "Festa" (Vidas secas). Acostumados à simplicidade das camisas e alpercatas, foi uma tarefa sacrificante para ambos vestir paletós e colarinhos e calçar botas e sapatos "duros como pau" (RAMOS, 2008, p. 46). Para eles, roupas de viagem e de festa aprisionavam o corpo da mesma maneira que o cárcere para Fabiano, e a escola para o menino. 317 Celdon FRITZEN, Doutor em Teoria e História Literária pela Universidade Estadual de Campinas. Professor adjunto da Universidade Federal de Santa Catarina na área de Literatura Portuguesa. Gladir da Silva CABRAL, Doutora em Letras pela Universidade Federal de Santa Catarina. Professora da Universidade do Extremo Sul Catarinense, no curso de Letras e no Programa de Pós-Graduação em Educação.

318 FRITZEN, Celdon \& CABRAL, Gladir da Silva. "O gênero autobiográfico e a representação da infância na literatura: Minha vida de menina, Infância, e Os bichos que tive". In: CUNHA, João Manuel dos Santos (Org.)
} 
outro". Para os autores, entre aquele que escreve e aquele sobre o qual se escreve existe uma grande distância, uma separação que passa pela reconstituição do passado" e a recriação da história vivida por meio da linguagem.

O escritor Ricardo Ramos ${ }^{319}$, em estudo biográfico sobre o pai, afirma não saber "até que ponto foi compreendido esse processo do Graciliano memorialista":

Sei que aqui e ali, com alguma frequência, há quem estranhe certas figuras de Infância e Memórias do cárcere. Isso de pai e mãe, ou de esposa, de repente surgirem como personagens, em toda uma gama conflituosa, não é muito comum. No entanto será o método do escritor dar às suas memórias um tratamento próximo ao da ficção, antepondo, aguçando, ampliando (RAMOS, 1992, p. 25).

Para Ramos Filho,

boa parte dos que leram Infância imagina um menino sombrio, criado entre adultos excessivamente rígidos e brutos. A imagem fica reforçada por tratar-se de um livro de memórias. 0 que devemos considerar, entretanto, é que mais do que um quadro particular de uma criança criada no início do século XX no sertão de Alagoas, a obra nos traz um cenário menos individual. 0 modelo de infância exposto é abrangente, de época e região, e nele existe também a opinião crítica do escritor relativamente a esse modelo (RAMOS FILHO, 2013, p. 35).

Assim, o relevo de Infância está justamente no fato de que, mesmo se tratando de uma obra memorialística, a narrativa traz em si todos os elementos literários passíveis de interpretação, do mesmo modo que os textos ficcionais analisados nos capítulos precedentes.

Literatura comparada: questões metodológicas e estratégias críticas. Caderno de Letras, n.14: 33-41, 2008, p. 139.

${ }^{319}$ Ricardo Ramos (1929-1992), filho de Graciliano Ramos, escritor. 
No que se refere ao estudo da infância no início do século XX, isso é ainda mais valioso, uma vez que um narrador minucioso e perspicaz como é o de Infância nos ajuda a compreender melhor esse fragmentário e nebuloso período da vida por que passam todas as pessoas e sobre o qual, em uma época em que a infância não tinha vez nem voz, descortinam-se possibilidades de estudo e análise.

Desse modo, um narrador que age e observa, que descreve e revela cenas e sensações vividas, experimentadas ou imaginadas, testemunhadas ou apenas ouvidas, recontadas ou inventadas, recria suas memórias com o olhar inocente e a sensibilidade da criança, mas amparado pela engenhosidade do escritor maduro, que segura a mão do menino e com ele refaz o caminho de sua história, tornando esta uma das principais obras literárias sobre a infância no Brasil. 
"The Child is father of the Man".

William Wordsworth (1802) 
Considerações Finais 


\section{Considerações Finais}

"Só tenho palavras

para o indizível.

Só tenho voz

para emudecer. [...]

Uma única certeza demora em mim: o que em nós já foi menino não envelhecerá nunca"

Mia Couto $(2011)^{320}$

Um trabalho de pesquisa acadêmica é fruto de muita dedicação, seriedade e comprometimento. Mas um trabalho de pesquisa que envolve escritores e obras tão importantes do nosso cenário literário exige ainda certa dose de ousadia, uma vez que, ao mesmo tempo que a releitura de textos consagrados nos permite sempre uma nova análise, à luz do nosso tempo, podemos cair na armadilha de dizer o que muitos já disseram antes, de formular conceitos há muito já estabelecidos e discutidos. Por isso talvez tenha sido este o maior desafio desta tese: tentar trazer alguma novidade por meio da análise de obras tão conhecidas e estudadas.

320 Mia Couto. Versos do poema "Declaração de bens" in: Tradutor de chuvas (2011). 
Assim, considerando-se o fato de que as representações da infância interessaram muito pouco à literatura até o final do século XVIII ${ }^{321}$, tendo isso ocorrido de forma mais incisiva apenas a partir de meados do século XIX, na Europa, e do início do século XX, no Brasil, nosso principal intuito foi o de resgatar imagens da infância retratadas em nossa literatura no período compreendido entre 1920 e 1945. Conforme já discutido e justificado, o intervalo de tempo escolhido caracterizou-se por importantes transformações políticas, sociais e econômicas, não somente no Brasil, mas em todo o mundo ${ }^{322}$. Além disso, no caso da literatura brasileira, em especial, esse mesmo período localizado entre o prenúncio e o fim do movimento modernista revelou outra interessante "coincidência": ao mesmo tempo em que, de um lado, diferentes autores dedicavam-se a escrever sobre a infância brasileira, de outro se constituía - por meio das obras pioneiras de Monteiro Lobato - uma literatura infantil genuinamente brasileira.

É importante lembrar que falar sobre a infância sempre requer certos cuidados, em vista das diferentes concepções que o termo compreende, dependendo da época e do local em que os objetos de estudo se encerram. No caso da arte e da literatura, mais especificamente, é preciso considerar ainda o contexto social e político em que as obras foram concebidas, e avaliar a motivação de cada autor na representação desse período de vida tão intrinsecamente relacionado a suas reminiscências mais remotas.

Desse modo, tomando os dizeres de Candido, de acordo com os quais a literatura é "um sistema vivo de obras, agindo umas sobre as outras e sobre os leitores; e só vive na medida em que estes a vivem, decifrando-a, aceitando-a, deformando-a" (1967, p. 86), realizamos nossa pesquisa procurando encontrar, nas obras analisadas, representações da infância no Brasil em um período marcado pela "liberdade criadora" que mudou os paradigmas das manifestações artísticas e literárias, abrindo caminhos para uma nova maneira de expressão. Desse período, elencamos quatro textos que apresentam perfis de diferentes protagonistas infantis: o conto "Negrinha", de Monteiro Lobato, integrante da coletânea homônima publicada em 1920, e os romances Menino

321 Conforme discutido no Capítulo 1 desta tese, e pelos motivos já expostos (CHOMBART DE LAUWE, 1991, p. 7). Exceção feita às obras voltadas à recepção infantil.

322 Conforme já discutido na Introdução, os impactos causados pelas duas grandes guerras mundiais, o crescimento da indústria, a expansão das comunicações e o surgimento de novas potências mundiais foram alguns dos fatores determinantes que marcaram o início do século XX, tanto na Europa como na América. 
de engenho, de José Lins do Rego (1932), Capitães da Areia, de Jorge Amado (1937) e Infância, de Graciliano Ramos (1945). Os três romances fazem parte do chamado movimento regionalista nordestino ${ }^{323}$, que se estabeleceu especialmente durante a década de 1930 e apresentou como principais novidades na prosa literária a liberdade temática e o vigor estilístico, constituindo-se "uma das correntes mais poderosas da nossa literatura" (CANDIDO \& CASTELLO, 1967, p. 28). Já o conto de Monteiro Lobato "Negrinha" - precede a eclosão do Modernismo, prenunciando algumas das importantes mudanças que estavam por vir, o que se pode depreender da análise de seus três livros de contos publicados pouco antes da Semana de 22: Urupês (1918), Cidades mortas (1919) e Negrinha $(1920)^{324}$.

Tomando os estudos sociológicos de Gilberto Freyre ${ }^{325}$ acerca das relações sociais e da constituição da família brasileira nos séculos anteriores ao período estudado, tivemos também como interesse buscar nos textos de ficção traços da infância descrita pelo sociólogo e vestígios de uma sociedade patriarcal e escravocrata. Por fim, a partir da breve análise biográfica de cada um dos autores estudados, com destaque para os fatos que pudessem ter contribuído para forjar no homem o escritor, procuramos estabelecer algumas relações entre infância, juventude, memória e criação.

O principal critério de inclusão das obras na pesquisa era que trouxessem crianças como protagonistas. Por meio de nosso recorte, pudemos analisar diferentes personagens infantis: uma menina (Negrinha), dois meninos (Carlinhos e o narrador de Infância) e um grupo de crianças de rua formado por dezenas de "moleques de todas as cores"326. As idades dos personagens analisados variam em cada obra. Enquanto Negrinha e os principais integrantes dos Capitães da Areia são apresentados pelo narrador com idade fixa ou aproximada ${ }^{327}$, os meninos de José Lins do Rego e Graciliano

323 Embora o romance memorialista de Graciliano Ramos tenha tido uma publicação tardia (1945), conforme esclarecemos ao longo da tese os primeiros relatos que compõem Infância foram escritos na década de 1930.

324 Conforme discutimos no Capítulo 2.

325 Considerando as obras Casa-Grande e Senzala (1933) e Sobrados e Mucambos (1936).

326 Embora a etnia das personagens não fosse objeto do estudo, ao abordarmos o tema "vestígios da escravidão" torna-se relevante o fato de que entre os protagonistas das obras analisadas temos crianças negras ou mulatas tanto em "Negrinha" como em Capitães da Areia. Personagens negros também são citados em Menino de engenho e Infância (por exemplo, a negra Luísa e o moleque José, respectivamente).

327 Negrinha é apresentada pelo narrador como "uma pobre órfã de sete anos” (LOBATO, 1959, p. 3). Já as idades de alguns dos principais integrantes dos Capitães da Areia são reveladas aos poucos, no decorrer da narrativa. Assim, o narrador informa que Pedro Bala tem quinze anos, João Grande, treze, Sem- 
Ramos, "crescem" à medida que a trama se desenvolve e, em ambas as narrativas, contam suas respectivas histórias desde os primeiros anos de vida ${ }^{328}$ até $o$ início da puberdade 329 .

Os romances de José Lins do Rego (Menino de engenho) e de Graciliano Ramos (Infância) também se aproximam entre si tanto pelo caráter autobiográfico que apresentam $^{330}$ como pelo foco narrativo: narradas em primeira pessoa, as obras premitem ao leitor maior intimidade para caminhar com os protagonistas em suas incursões pela memória. Por outro lado, as narrativas de Monteiro Lobato e de Jorge Amado, cada qual com suas características e suas especificidades, voltam as atenções para a criança excluída, abandonada ou órfã ${ }^{331}$, desprovida de direitos, herdeira das desigualdades sociais oriundas de um regime escravocrata e de uma sociedade que se mostra despreparada para acolher os menores desamparados. Os narradores de ambas as obras são criados habilmente por seus respectivos autores de modo a não se limitar em contar uma história. Dessa forma, enquanto Monteiro Lobato constrói um narrador crítico que emite opiniões e descreve cenas e pessoas com ironia e sarcasmo, o narrador de Jorge Amado parece fazer parte do bando de "crianças ladronas", buscando em um passado recente os principais fatos que marcaram a vida de cada uma delas, talvez como uma forma de tentar justificar ou minimizar seus atos ilícitos. Assim, os meninos são apresentados com inocência e lirismo, com humor e complacência, como se o narrador conhecesse seus desejos e medos mais íntimos, em um discurso que se contrapõe ao tom acusatório determinado pelos textos introdutórios e intermediários que relatam sem floreios os crimes praticados pelo grupo.

Pernas, dezesseis, Gato, catorze, Dora, com idade aproximada entre treze e catorze anos, Zé Fuinha, seis (AMADO, 2008).

${ }^{328}$ Apesar de não apresentar uma narrativa linear, Infância revela no primeiro capítulo a idade a que o narrador atribui suas lembranças mais remotas: "Que idade teria eu? Pelas contas de minha mãe, andava em dois ou três anos" (RAMOS, 2008, p. 10). Em Menino de engenho, logo na abertura do livro o narrador também revela certa imprecisão: "Eu tinha uns quatro anos no dia em que minha mãe morreu" (REGO, 2013, p. 25).

3290 narrador de Infância apresenta a idade final e as incômodas mudanças que marcavam entrada na puberdade: "Aos onze anos experimentei grave desarranjo. Atravessando uma porta, choquei no batente, senti dor aguda. Examinei-me, supus que tinha no peito dois tumores. Nasceram-me pelos, emagreci - e nos banhos coletivos do Paraíba envergonhei-me da nudez" (RAMOS, 2008, p. 261). Já o narrador de Menino de engenho revela sua idade e seus descaminhos: "Os homens riam-se das intemperanças dos meus doze anos (REGO, 2013, p. 138).

${ }^{330}$ As discussões sobre o caráter autobiográfico das obras Menino de engenho e Infância estão nos Capítulos 3 e 5, respectivamente.

${ }^{331}$ Embora a situação de Carlinhos em Menino de engenho também seja a de órfão, o personagem não se enquadra neste grupo por ter sido acolhido e criado pela família, em um contexto bem diferente do apresentado pelos personagens de Monteiro Lobato e Jorge Amado. 
É interessante notar que, apesar das diferenças entre estilos, autores e contextos em que as quatro obras foram escritas, vários temas são recorrentes em todas as narrativas, promovendo diálogos possíveis entre elas. Vestígios da escravidão, castigos corporais a que as crianças são submetidas, contraposição entre liberdade e sujeição e a despedida da infância são alguns deles. É, então, a partir desses quatro temas que encerraremos estas considerações finais, procurando mostrar como esses laços se formam entre as obras nas diferentes representações da infância, sem perder de vista a "relação arbitrária e deformante que o trabalho artístico estabelece com a realidade", conforme nos alerta Candido (1967, p. 14).

Vestígios da escravidão estão presentes em todas as obras analisadas. Negrinha é a própria personificação de uma herança escravocrata. Sem lugar nem na senzala nem na casa grande, a menina vivia como agregada, dependente dos "favores" e das "bondades" de dona Inácia, que lhe dava comida, uma "esteira rota" e "trapos imundos" em troca do prazer de ter alguém a quem maltratar: "Como era boa para um cocre!” (LOBATO, 1956, p. 12) ${ }^{332}$. Em Menino de Engenho, “a senzala do Santa Rosa não desaparecera com a abolição. Ela continuava pegada à casa-grande, com as suas negras parindo, as boas amas de leite e os bons cabras do eito" (REGO, 2013, p. 80). A presença de ex-escravos e seus descendentes ainda era muito marcante no início do século XX, especialmente nos engenhos ${ }^{333}$. A figura da "negrinha de estimação" de tia Sinhazinha, "que dormia aos pés de sua cama" e que a velha mantinha junto de si "para judiar, para satisfazer os seus prazeres brutais", remete-nos à relação análoga que dona Inácia mantinha com Negrinha, na obra lobatiana. Em Infância, resquícios da escravidão podem ser encontrados no capítulo "O moleque José”, em que o narrador explica detalhadamente a ascendência de seu companheiro na meninice ${ }^{334}$. Já em Capitães da

\footnotetext{
332 "A excelente dona Inácia era mestra na arte de judiar de crianças. Vinha da escravidão, fora senhora de escravos - e daquelas ferozes, amigas de ouvir cantar o bolo e estalar o bacalhau. Nunca se afizera ao regime novo - essa indecência de negro igual a branco [...]" (LOBATO, 1956, p. 5).

333 "As negras do meu avô, mesmo depois da abolição, ficaram todas no engenho [...]. 0 meu avô continuava a dar-lhes de comer e vestir. E elas a trabalharem de graça, com a mesma alegria da escravidão. As suas filhas e netas iam-lhes sucedendo na servidão, com o mesmo amor à casa-grande e a mesma passividade de bons animais domésticos. Na rua a meninada do engenho encontrava os seus amigos: os moleques, que eram os companheiros, e as negras que lhes deram os peitos para mamar; as boas servas nos braços de quem se criaram" (REGO, 2013, p. 75-76).

334 “A preta Quitéria engendrou vários filhos. Os machos fugiram, foram presos, tornaram a fugir - e antes da abolição já estavam meio livres. Sumiram-se. As fêmeas, Luísa e Maria, agregavam-se à gente do meu avô. Maria, a mais nova, nascida forra, nunca deixou de ser escrava. E Joaquina, produto dela, substituiua na cozinha até que, mortos os velhos, a família não teve recurso para sustentá-la" (RAMOS, 2008, p. 85).
} 
Areia, Jorge Amado nos revela outra faceta da desigualdade social promovida pelo regime escravocrata: a realidade das crianças abandonadas ou crianças de rua, que, sem ter onde morar ou a quem recorrer, constituíam bandos e viviam de furtos e de pequenos delitos ${ }^{335}$. Órfãs ou fugidas de casa para tentar uma melhor condição de vida ou evitar maus-tratos, as crianças unem-se para tentar sobreviver ${ }^{336}$.

Heranças de uma sociedade patriarcal também podem ser verificadas nos castigos físicos a que as crianças eram submetidas nessa época. De acordo com os estudos de Gilberto Freyre, o domínio do pai na administração da justiça e da família concedia-lhe o direito de castigar não somente os escravos e as "crias da casa", mas também os próprios filhos (1996, p. 68). Para o autor, a criança era castigada "por uma sociedade de adultos em que o domínio sobre o escravo desenvolvia, junto com as responsabilidades de mando absoluto, o gosto de judiar também com o menino" (p. 6869).

Nas quatro obras analisadas, os castigos corporais a que as crianças eram submetidas são relatados com maior ou menor intensidade. Em "Negrinha", o narrador descreve toda a gama sortida de punições que a menina sofria diariamente, "por ação ou omissão", "houvesse ou não houvesse motivo" (LOBATO, 1947, p. 4-5). As maldades eram das mais variadas: "cocres: mão fechada com raiva e nós de dedos que cantam no coco do paciente"; puxões de orelha - o "torcido" e o "sacudido"; beliscões; tapas, cascudos pontapés e safanões, além da surra com vara de marmelo. "Divertidíssimo", de acordo com o sarcástico narrador. Castigos maiores vinham "de quando em quando", "para desobstruir o fígado e matar as saudades do bom tempo" (p. 6), como, por exemplo, o episódio do ovo fervente colocado na boca da menina - que é descrito com pormenores (p. 7). Também o narrador de Infância revela sem restrições os castigos que lhe impingiam: chineladas, cocorotes com os dedos dobrados, "duros como martelos", sacudidas, puxões de orelha, sovas com o côvado, surras com corda nodosa e com chicote. Apesar de sentido, o menino entendia as punições como parte inerente da

\footnotetext{
335 Conforme discutido no Capítulo 4, tanto a desigualdade social como a herança de uma sociedade escravocrata são fatores ligados diretamente na gênese de uma infância em situação de risco.

336 A descrição de João Grande exemplifica a sina de boa parte dos integrantes do bando: "É alto, o mais alto do bando, e o mais forte também, negro de carapinha baixa e músculos retesados, embora tenha apenas treze anos, dos quais quatro passados na mais absoluta liberdade, correndo as ruas da Bahia com os Capitães da Areia. Desde aquela tarde em que seu pai, um carroceiro gigantesco, foi pegado por um caminhão quando tentava desviar o cavalo para um lado da rua, João Grande não voltou à pequena casa do morro. Na sua frente estava a cidade misteriosa, e ele partiu para conquistá-la" (AMADO, 2008, p. 30).
} 
infância: "Batiam-me porque podiam bater-me, e isto era natural" (p. 33). Já em Capitães da Areia, os relatos de agressões físicas limitam-se a situações em que os menores são presos ou então quando se lembram de fatos antigos. A história de Sem-Pernas, por exemplo, revela uma infância marcada por maus-tratos: o menino era espancado pelo "padrinho" que o criava, motivo que o fez fugir de casa. Já vivendo na rua, foi hostilizado por homens, empurrado por guardas e apanhou de moleques maiores. 0 castigo maior acontece, porém, quando é preso e humilhado por "soldados bêbados", que o fizeram correr com sua perna coxa em volta de uma saleta enquanto o surravam com uma borracha comprida, até que ele desistisse de lutar (AMADO, 2018, p. 38). Pedro Bala é outra vítima da violência praticada por policiais. Capturado em uma das ações do bando e levado ao reformatório, o chefe dos Capitães da Areia nega-se a delatar os companheiros, e por isso é torturado com chicotadas, socos e pontapés (p. 201). Nas quatro narrativas analisadas, apenas Carlinhos, de Menino de Engenho, é poupado de penas mais severas, porém mesmo assim não escapa de eventuais beliscões, chineladas e cocorotes de tia Sinhazinha, que dizia: "Menino só endireita com chinela!" (REGO, 2013, p. 44-45).

Outro tema recorrente nas quatro obras revisitadas é a contraposição entre liberdade e sujeição. No conto lobatiano, embora a trama se passe em uma época posterior à libertação dos escravos, e Negrinha fosse uma criança "livre", ela vivia encarcerada. Privada até das ações cotidianas mais básicas, como andar e falar, a menina mal se mexia no local onde era colocada diariamente: “a boa senhora punha-a na sala, ao pé de si, num desvão da porta". O narrador faz questão de sublinhar a acinesia da criança durante várias passagens do conto: de bico calado e braços cruzados, "Negrinha imobilizava-se no canto, horas e horas" (LOBATO, 1959, p. 4). 0 comportamento da menina poderia ser equiparado ao da ave presa no relógio cuco, que de hora em hora punha a cabeça para fora para anunciar a passagem de tempo. A única exceção à paralisia da personagem ocorre no episódio em que lhe é permitido brincar com as sobrinhas de dona Inácia no jardim. E isso acaba custando-lhe a vida.

Já nos três romances analisados, apesar de os personagens centrais desfrutarem de momentos de liberdade, todos passam por algumas situações de sujeição e encarceramento. No engenho do avô, Carlinhos vive "de pés no chão, solto como um bicho" (REGO, 2013, p. 35); usufrui da autonomia conquistada por meio de 
seus passeios de carneiro e de suas aventuras libidinosas com os moleques da bagaceira. 0 menino sente-se preso somente quando sofria de asma e ficava longos períodos fechado em seu quarto, impedido de brincar com os amigos e de fazer seus passeios pelo engenho ${ }^{337}$ : “A minha vida ia ficando como a dos meus canários prisioneiros, enquanto os meus primos se soltavam e um magnífico verão se abria em dias de festa de sol, em noites brancas de lua cheia" (p. 118-119). 0 que viria, porém, tirar-lhe definitivamente a liberdade era o internato, para onde seria enviado: “Colégio amansa menino" (p. 138).

Também para o narrador de Infância a escola era uma oposição à liberdade: “Não há prisão pior que uma escola primária do interior. A imobilidade e a insensibilidade me aterraram. Abandonei os cadernos [...], não deixei que as moscas me comessem" (RAMOS, 2008, p. 206). Antes da escola, porém, o menino já havia experimentado essa contraposição entre "liberdade" e "prisão" quando, ainda pequeno, sentiu-se pela primeira vez tolhido de seus movimentos com roupas de viagem e calçados duros: "na roupa estreita, movia-me com dificuldade. Em geral eu usava camisa, saltava e corria como um bichinho" (p. 46). Aprisionado em seu próprio corpo, o menino ansiava voltar à fazenda, onde podia viver solto, livre "como um pequeno animal" (p. 12): "o paletó feria-me os sovacos, os sapatos mordiam-me os pés [...]. Senti falta da camisa e das alpercatas. [...] Senti vontade de chorar" (p. 47-48).

Esse anseio à liberdade é um dos principais temas explorados em Capitães da Areia. Logo no início do romance essa questão é proposta no diálogo entre o menino Raul e Pedro Bala: o primeiro tinha "uma bicicleta e muito brinquedo"; o segundo, "a rua e o cais". Essa questão sobre a liberdade dos meninos de rua ainda seria retomada durante o romance: na descrição do grupo ${ }^{338}$, nas tentativas frustradas do Padre José Pedro em recolocar as crianças em casas de famíliaa ${ }^{339}$, nos episódios do Orfanato ${ }^{340}$ e do

\footnotetext{
337 “Uma moléstia horrível [...]. Tenho uma impressão de terror das minhas noites de asmático, dos meus dias compridos em cima da cama, dos vomitórios abomináveis que me davam. Eram acessos de mais de três dias. Depois a convalescença, sem poder pisar no terreiro, sem ir ao alpendre por causa do mormaço, do sereno, dos chuviscos. As noites pareciam-me uma eternidade. [...] Essas noites de puxado envelheciam a minha meninice [...]" (REGO, 2013, p. 99-101).

338 "Ali estavam mais ou menos cinquenta crianças, sem pai, sem mãe, sem mestre. Tinham de si apenas a liberdade de correr nas ruas" (AMAD0, 2008, p. 46).

339 "Numa coisa se enganou, a princípio, o padre José Pedro: em lhes oferecer, em troca do abandono da liberdade que gozavam, soltos na rua, uma possibilidade de vida mais confortável. [...] isso seria o abandono de tudo de grande que tinha a vida deles: a aventura da liberdade nas ruas [...]” (p. 75).

340 "Um mês de orfanato bastou para matar a alegria e a saúde de Dora. Nascera no morro, infância em correrias no morro. Depois a liberdade das ruas da cidade, a vida aventurosa dos Capitães da Areia. Não era uma flor de estufa. Amava o sol, a rua, a liberdade" (p. 217).
} 
Reformatório $^{341}$, no suicídio de Sem-Pernas ${ }^{342}$. Para os Capitães da Areia, a liberdade era tudo o que eles tinham. Ao tirar-lhes a liberdade, tiravam-lhe a vida. Para o Padre José Pedro, "a liberdade era o sentimento mais arraigado nos corações os Capitães da Areia" (p. 77).

A despedida da infância também é tema presente em todas as narrativas analisadas. No caso do conto "Negrinha", trata-se de uma infância interrompida pela morte da personagem, "envenenada" pela lembrança de um dezembro ensolarado em meio a seu "doloroso inferno" (LOBATO, 1957, p. 11). Já nos romances de Graciliano Ramos e de José Lins do Rego, os meninos crescem até a entrada na puberdade ${ }^{343}$. Porém, enquanto o narrador de Infância termina sua história envergonhando-se da nudez como se seu corpo "se tivesse tornado impuro e feio de repente" e recompondo o vestuário com "terno de casimira, chapéu de feltro, sapatos americanos e uma gravata vermelha" (RAMOS, 2008, p. 261-262), o menino Carlinhos já havia deixado a infância e os pudores para trás: "Via-me mais alguma coisa que um menino; e mesmo já me olhavam diferente. Já não tinham para mim as condescendências que se reservam às crianças. As negras faziam-me de homem" (REGO, 2013, p. 136).

A sexualidade também fazia dos Capitães da Areia homens antes do tempo. Embora tivessem apenas entre nove e dezesseis anos de idade, a maioria dos meninos já mostrava comportamento de homens feitos, fumando, bebendo e mostrando intensa intimidade com os prazeres do sexo. Porém em alguns episódios revelam-se nada mais que inocentes crianças, ávidas por um pouco de proteção e carinho. No final do romance, com exceção daqueles que não chegam à vida adulta - como Almiro, Sem-Pernas e Dora $^{344}$ - têm-se notícia do destino de alguns dos principais integrantes do bando, já crescidos agora também na idade. Desse modo, os meninos despedem-se da infância sem deixar de levar dela tudo o que ali viveram, tanto para o bem, como para o mal; no trapiche forjaram-se tanto bandidos e vigaristas como jovens sonhadores:

\footnotetext{
341 "Na madrugada, quando Pedro acordou, os presos cantavam. Era uma moda triste. Falava do sol que havia nas ruas, em quanto é grande e bela a liberdade. [...] Lá fora, dizia a velha canção, é o sol, a liberdade e a vida" (p. 201-202).

3420 medo de ser novamente preso, confinado, surrado e humilhado faz com que o menino coxo opte pela liberdade eterna (capítulo "Como um trapezista de circo", p. 250-251).

3430 narrador de Infância termina seu relato com onze anos; Carlinhos, de Menino de engenho, com doze.

${ }^{344}$ Almiro morre de "alastrim"; Dora, de "febre", Sem-Pernas suicida-se, mergulhando no vazio.
} 
Pedro Bala foi aceito na organização no mesmo dia em que João Grande embarcou como marinheiro num navio cargueiro do Lloyd. No cais dá adeus ao negro, que parte para a sua primeira viagem. Mas não é um adeus como aquele que dera aos outros que partiram antes. Não é mais um gesto de despedida. É um gesto de saudação ao companheiro que parte. [...]

Pedro Bala entra no trapiche. A noite cobriu a cidade. A voz do negro canta no mar. A estrela de Dora brilha quase tanto quanto a lua no céu mais lindo do mundo. [...] De punhos levantados, as crianças saúdam Pedro Bala, que parte para mudar o destino de outras crianças (AMADO, 2008, p. 267-269).

Na Introdução deste trabalho, imaginando o percurso que estaria por ser feito, afirmamos que "escrever sobre a infância é, de certo modo, fazer uma viagem ao passado", voltando os olhos para a criança que fomos um dia, e que vive, ainda que de forma latente, dentro de nós. Como afirmaria o poeta Manoel de Barros, em 2007: "tudo o que a gente é mais tarde vem da infância"345. Ou ainda como imortalizado duzentos anos antes, nos versos de William Wordsworth: "The Child is father of the Man" ${ }^{346}$ :

\author{
My heart leaps up when I behold \\ A rainbow in the sky: \\ So was it when my life began; \\ So is it now I am a man; \\ So be it when I shall grow old, \\ Or let me die! \\ The Child is father of the Man; \\ And I could wish my days to be \\ Bound each to each by natural piety ${ }^{347}$.
}

\footnotetext{
$345 \mathrm{Na}$ entrevista "Caminhando para as origens", a Bosco Martins (2007).

346 "O menino é pai do homem" ("The Child is father of the Man") é um verso do poema My heart leaps up (1802), de William Wordsworth (1770-1850), publicado em Poems in two volumes, em 1807.

347 "Meu coração se enternece / ao contemplar um arco íris no céu / Fora assim desde o início da minha vida / E hoje, assim, que homem sou / Assim o será quando um dia envelhecer / Ou, longe disso, quisera morrer / A Criança é o pai do Homem / Pudera meus dias um a um entrelaçados por esse sentimento de reverência / de amor e devoção à natureza" (tradução: K. Swartz).
} 
Porém, após a análise das quatro narrativas selecionadas para esta pesquisa, é possível ir além, e afirmar que escrever sobre a infância representada na literatura no início do século XX é como voltar um século atrás para observar de perto, por meio desses olhos ao mesmo tempo curiosos e amedrontados, a infância escondida em um desvão da porta, nos cantos da sala, embaixo dos cajueiros ou então adormecida, sob a lua, em um velho trapiche abandonado.

Com exceção de Negrinha, que não desfruta de uma infância senão quando lhe são permitidos breves momentos de sonho e brincadeira, os demais personagens possibilitam-nos reviver esse período de forma intensa. Assim, por meio da leitura dessas obras é possível acompanhar os devaneios melancólicos de Carlinhos e suas experiências de vida no engenho do avô; participar com o narrador de Infância de suas descobertas sobre as contradições do mundo e refazer ao seu lado os tortuosos caminhos no aprendizado da leitura; correr nas ruas da Bahia e no imenso areal branco com os Capitães da Areia, aventurando-nos com eles em sua luta diária pela sobrevivência.

Considerando-se também o contexto sociocultural em que as obras foram escritas e as histórias de vida de seus autores, é possível concluir que, mais que retratos esparsos de crianças construídas "de papel e tinta", os textos, em seu conjunto, nos trazem importantes reflexões sobre a infância no Brasil nesse período situado na primeira metade do século XX. É possível afirmar ainda que, em uma época marcada por profundas transformações sociais, políticas, econômicas e artísticas, ecos do passado ainda eram ouvidos nas ruínas das senzalas, nas cozinhas das casas-grandes, na infância abreviada e nas vozes ensurdecidas daquelas crianças. 


\section{Bibliografia}

\section{CORPUS PRINCIPAL}

AMADO, Jorge. Capitães da areia. 2. ed. São Paulo: Cia. das Letras, 2008.

LOBATO, José Bento Monteiro. “Negrinha” In: Negrinha. 9. ed., São Paulo: Brasiliense, 1959, p. 3-12.

RAMOS, Graciliano. Infância. 39. ed. Rio de Janeiro: Record, 2008.

REGO, José Lins do. Menino de engenho. 105. ed. Rio de Janeiro: José Olympio, 2013.

\section{REFERÊNCIAS BIBLIOGRÁFICAS}

ABRAMOWICZ, A. e OLIVEIRA, F. "A Sociologia da Infância no Brasil: uma área em construção” In: Revista do Centro de Educação, Vol. 35, n. 1. Santa Maria: UFSM, 2010.

ALVIM, Maria Rosilene B.; VALLADARES, Licia do Prado. "Infância e sociedade no Brasil: uma análise da literatura". Boletim Informativo e Bibliográfico - BIB, no. 26. Rio de Janeiro: Relume-Dumará/Anpocs, 1988, p. 3-37.

AMADO, Jorge. O menino grapiúna. Rio de Janeiro: Record, 1982.

ANDERSEN, Hans Christian. The complete fairy tales. Ware (GB): Wordsworth Editions, 1997.

ANDRADE, Carlos Drummond. "José Lins" IN: REGO, J. L. Menino de engenho. Nota de Carlos Drummond de Andrade; estudo de Antônio Carlos Villaça. 80. ed. Rio de Janeiro: José Olympio, 2001.

APPEL, Carlos Jorge. "Lobato: um homem da república velha” In: ZILBERMAN, Regina. Atualidade de Monteiro Lobato. Porto Alegre: Mercado Aberto, 1983.

ARIÈS, Philippe. História social da criança e da família. Trad. Dora Flaksman. 2. ed., Rio de Janeiro: LTC, 1981.

ARROYO, Leonardo. Literatura infantil brasileira. 3.ed., São Paulo: Unesp, 2011.

ASSIS, Machado. Dom Casmurro. In: Machado de Assis. Todos os romances e contos consagrados: Volume 2. Rio de Janeiro: Nova Fronteira, 2016b. 
Memórias póstumas de Brás Cubas. In: Machado de Assis. Todos os romances e contos consagrados: Volume 2. Rio de Janeiro: Nova Fronteira, 2016.

. "Conto de escola" in: Machado de Assis: seus trinta melhores contos. 6. ed., Rio de Janeiro: Nova Fronteira, s/d, p. 217-226.

AYUB, João Paulo. "'Venta-Romba' e o silêncio da palavra negada: a escuta das margens em Infância, de Graciliano Ramos in e-scrita. Revista do Curso de Letras. V.6, N.1. Nilópolis: UNIABEU, 2015, p. 14-23.

BANDEIRA, M. "Ciclo da cana de açúcar". in: COUTINHO, Eduardo \& CASTRO, Angela Bezerra (Orgs.). José Lins do Rego. João Pessoa, FUNESC; Rio de Janeiro: Civilização Brasileira, 1991.

BARABINO, Andrea. "L'età dell'innocenza" in: Media Classica, Dipartimento di Antichità, Fliosofia e Storia dell'Università di Genova. s/d.

BENJAMIN, Walter. "Brinquedo e brincadeira: observações sobre uma obra monumental" in: Magia e técnica, arte e política: obras escolhidas. 7. ed. São Paulo: Brasiliense, 1994, p. 249-253.

. "Sobre o conceito da História" in: Magia e técnica, arte e política: ensaios sobre literatura e história da cultura. 7. ed. São Paulo: Brasiliense, 1994b, p. 222-234.

BIGNOTTO, Cilza Carla. Personagens infantis da obra para crianças e da obra para adultos de Monteiro Lobato : convergências e divergências [DISSERTAÇÃO]. Campinas: UNICAMP, 1999.

BOSI, Alfredo. História concisa da literatura brasileira. 3. ed., São Paulo: Cultrix, 1990.

BOSETTI, Gilbert, autor de L'enfant-dieu et le poète - Culte et poétiques de l'enfance dans le roman italien du XXème siècle, 1997. APUD MAGALHÃES, Violante. Sobressalto $e$ espanto: narrativas literárias sobre e para a infância, no neo-realismo português. Lisboa: Universidade de Lisboa, 2008 [TESE].

BREDSDORFF, Elias. Hans Christian Andersen, a biography. Suffolk: Souvenir Press, 1975.

BULHÕES, Marcelo Magalhães. Literatura em campo minado: a metalinguagem em Graciliano Ramos e a tradição literária brasileira. São Paulo: Annablue/FAPESP, 1999.

CAMPBELL, J. O herói de mil faces, 7. ed., São Paulo: Cultrix, 2002.

CANDIDO, Antonio. Literatura e sociedade. São Paulo: Nacional, 1967.

. Ficção e confissão: ensaios sobre Graciliano Ramos. 3. ed. Rio de Janeiro: Ouro sobre Azul, 2006. 
Formação da Literatura Brasileira, vol. 2. 5. ed. São Paulo: USP, 1975.

CANDIDO, Antonio \& CASTELLO, Aderaldo. Presença da literatura brasileira. Volume III

- Modernismo. 3. ed. São Paulo: Difusão Europeia do Livro, 1968.

CARDOSO, Laís de Almeida. Percurso do órfão na Literatura Infantil/Juvenil, da oralidade à era digital: a trajetória do herói solitário [Dissertação]. Universidade de São Paulo. São Paulo: FFLCH-USP, 2006.

CARDOSO, Zelia. O romance paulista no século XX. Volume 12. São Paulo: Biblioteca Academia Paulista de Letras, 1983.

CASTELLO, José Aderaldo. A literatura brasileira: origens e unidade. Volume II. São Paulo: EDUSP, 1999.

. "Memória e regionalismo" In: REGO, J. L. Menino de engenho. 10 ed. Rio de Janeiro: José Olympio, 1966.

. José Lins do Rego: Modernismo e Regionalismo. São Paulo: Edart, 1961.

CASTRO, M. “A emoção e a glória de um escritor” in: REGO, José Lins. Menino de engenho. 105. ed. Rio de Janeiro: José Olympio, 2013.

CAVALHEIRO, E. Monteiro Lobato - Vida e obra. São Paulo: Nacional, 1955.

CECCANTINI, João Luís. "Cinquenta tons de verde: Urupês, o primeiro best-seller nacional". In: LAJOLO, Marisa (org.). Monteiro Lobato, livro a livro: obra adulta. São Paulo: UNESP, 2014, p. 43-58.

CHAGURI, Mariana. O romancista e o engenho: José Lins do Rego e o regionalismo nordestino dos anos 1920 e 1930. São Paulo: Aderaldo \& Rothschild - ANPOCS, 2009.

CHOMBART DE LAUWE, Marie-José. Um outro mundo: a infância. São Paulo: Perspectiva, 1991.

COELHO, Nelly Novaes. Panorama histórico da Literatura Infantil/Juvenil. 4.ed., São Paulo: Ática, 1991.

Dicionário crítico da literatura infantil e juvenil brasileira. São Paulo:

EDUSP, 1995.

COLLODI, Carlo. Le aventure di Pinocchio. Milano: Mondadori, 2005.

COSEnZA, R. M. \& GUERRA, L.B. Neurociência e educação. Como o cérebro aprende. Porto Alegre: Artmed, 2011. 
COUTINHO, Eduardo \& CASTRO, Angela Bezerra (Orgs.). José Lins do Rego. João Pessoa, FUNESC; Rio de Janeiro: Civilização Brasileira, 1991.

CUNNINGHAM, H. The Invention of Childhood. London: BBC, 2006 APUD TAVARES, Fabiana. Quase como antes: a (des)construção das representações de infância da classe trabalhadora na literatura infantil e juvenil. São Paulo: USP, 2014 [TESE].

DANTAS, Cauby. Gilberto Freyre e José Lins do Rego: diálogos do senhor da casa-grande com o menino de engenho. EDUEPB: Campina Grande, 2015.

DE AMICIS, Edmondo. Cuore. Milano: Mondadori, 2005.

DEL PRIORE, Mary (org.) História das crianças no Brasil. 7. ed. São Paulo: Contexto, 2013.

DONZELOT, J. A Polícia das Famílias. Rio de Janeiro: Graal Ed., 1980 APUD ALVIM, Maria Rosilene B.; VALLADARES, Licia do Prado. "Infância e sociedade no Brasil: uma análise da literatura". Boletim Informativo e Bibliográfico - BIB, no. 26. Rio de Janeiro: RelumeDumará/Anpocs, 2º semestre, 1988.

DICIONÁRIO Houaiss Eletrônico.

DUARTE, Eduardo de Assis. "Jorge Amado, exílio e literatura". In: Aletria: Revista de Estudos de Literatura. V. 9, Belo Horizonte: UFMG, 2002, p. 226-236.

EDGCUMBE, E. R. P. Zephyrus: A holiday in Brazil and on the River Plate. London: Chatto \& Windus, Piccadilly, 1887.

ESTATUTO da Criança e do Adolescente. Lei Federal № 8.069, de 13 de julho de 1990, Art. 7ํㅡ, Capítulo 1 e Art. 4ํㅜ , Título 1. Presidência da República, Casa Civil, Subchefia para Assuntos Jurídicos.

FONSECA, Edson Nery. "Biobibliografia" in FREYRE, G. De menino a homem: de mais de trinta e de quarenta, de sessenta e mais anos. São Paulo: Global, 2010.

FREITAS, Marcos Cezar (org.). História social da infância no Brasil. 8.ed. São Paulo: Cortez, 2011.

FREITAS, Marcos Cezar e KUHLMANN Jr., Moysés. Os intelectuais na história da infância. São Paulo: Cortez, 2002.

FREUD, Sigmund. "A interpretação dos sonhos". In: Edição Standard Brasileira das Obras Psicológicas completas de S. Freud. Vol. IV. Rio de Janeiro: Imago, 1980 (Texto original de 1900).

FREYRE, Gilberto. Pessoas, coisas \& animais. Apresentação de Edson Nery da Fonseca. Porto Alegre, MPM Propaganda, 1979. 
De menino a homem: de mais de trinta e de quarenta, de sessenta e mais anos. São Paulo: Global, 2010.

. Sobrados e Mucambos. 9. ed., Rio de Janeiro: Record, 1996.

Casa-grande \& senzala, 50aㅡ ed. São Paulo: Global, 2005.

. "Recordando José Lins do Rego" IN: COUTINHO, E. \& CASTRO, A.B.

(Orgs.) José Lins do Rego. João Pessoa, FUNESC; Rio de Janeiro: Civilização Brasileira, 1991.

Interpretação do Brasil. 3. ed. São Paulo: Global, 2015.

FRITZEN, Celdon \& CABRAL, Gladir da Silva. "O gênero autobiográfico e a representação da infância na literatura: Minha vida de menina, Infância, e Os bichos que tive". In: CUNHA, João Manuel dos Santos (Org.) Literatura comparada: questões metodológicas $e$ estratégias críticas. Caderno de Letras. Faculdade de Letras. Universidade Federal de Pelotas: Pelotas, 2008, p. 33-41.

GODOY GALLARDO, Eduardo, La infancia de la narrativa española de posguerra, 19391978 (1979). APUD MAGALHÃES, Violante. Sobressalto e espanto: narrativas literárias sobre e para a infância, no neo-realismo português. Lisboa: Universidade de Lisboa, 2008 [TESE].

GRAMSCI, Antonio. Literatura e vida nacional. 3. ed. [Tradução de Carlos Nelson Coutinho]. Rio de Janeiro: Civilização Brasileira, 1986, apud DANTAS, Cauby. Gilberto Freyre e José Lins do Rego: diálogos do senhor da casa-grande com o menino de engenho. Eduepb: Campina Grande, 2015.

GREGORI, Maria Filomena \& SILVA, Cátia Aida. Meninos de rua e instituições: tramas, disputas e desmanche. São Paulo: Contexto, 2000.

GREGORI, Maria Filomena. "Meninos de rua e a viração" IN: PEDROSA, Adriano et al. Histórias da infância. São Paulo: MASP, 2016.

HATOUM, Milton. "O carrossel das crianças", in AMADO, J. Jorge. Capitães da areia. 2. ed. São Paulo: Cia. das Letras, 2008.

HUIZINGA, Johan. Homo ludens. São Paulo: Perspectiva, 2001.

INSTITUTO Moreira Salles. Cadernos de literatura brasileira. Número 3. São Paulo: IMS, 1997.

JUNQUEIRA, Ivan. José Lins do Rego: Dias idos e vividos. Rio de Janeiro: Nova Fronteira, 1981. 
LAJOLO, Marisa. "Infância de papel e tinta". In: FREITAS, Marcos Cezar (org.). História social da infância no Brasil. 8.ed. São Paulo: Cortez, 2011, p. 229-250.

. Monteiro Lobato: um brasileiro sob medida. São Paulo: Moderna, 2000. (org.). Monteiro Lobato, livro a livro: obra adulta. São Paulo: UNESP, 2014. . "A modernidade em Monteiro Lobato" In: ZILBERMAN, R. Atualidade de Monteiro Lobato. Porto Alegre: Mercado Aberto, 1983.

LAJOLO, Marisa \& ZILBERMAN, Regina. Literatura Infantil Brasileira: história e histórias. 6. ed., São Paulo: Ática, 1999.

LAUWE, Marie-José Chombart De. Um outro mundo: a infância. São Paulo: Perspectiva/ Edusp, 1991.

LEITÃO, Claudio. "Pósfácio" in RAMOS, Graciliano. Infância. 39. ed. Rio de Janeiro: Record, 2008, p. 269-282.

LEITE, Miriam L. Moreira. "A infância no século XIX segundo memórias e livros de viagem" IN FREITAS, Marcos Cezar (org.). História social da infância no Brasil. 8.ed. São Paulo: Cortez, 2011, p. 19-52.

LEVINAS, Emmanuel. Totalidade e infinito. Lisboa: Edições 70, 1980 APUD AYUB, João Paulo. "'Venta-Romba' e o silêncio da palavra negada: a escuta das margens em Infância, de Graciliano Ramos" in e-scrita. Revista do Curso de Letras. V.6, N.1. Nilópolis: UNIABEU, 2015, p. 14-23.

LOBATO, Monteiro. A barca de Gleyre. São Paulo: Globo, 2010.

.Urupês. 37. ed., São Paulo: Brasiliense, 2004.

. "Bucólica” IN: Urupês. São Paulo: Brasiliense, 2004b, p. 99-106.

“A vingança da peroba" IN: Urupês. São Paulo: Brasiliense, 2004c, p.

$55-69$.

. Negrinha. 9. ed., São Paulo: Brasiliense, 1959.

“O fisco” IN: Negrinha. São Paulo: Brasiliense, 1959b, p. 53-65.

. "Duas cavalgaduras" IN: Negrinha. São Paulo: Brasiliense, 1959c, p.

189-200.

Cidades mortas. 22. ed., São Paulo: Brasiliense, 1981. 
. "Pedro Pichorra" IN: Cidades mortas. São Paulo: Brasiliense, 1981b, p. 29-33.

A menina do narizinho arrebitado. São Paulo: Edição da Revista do Brasil, 1920. Reinações de Narizinho. 24. ed. São Paulo: Brasiliense, 1971.

LUCAS, Fabio. "A contribuição amadiana para o romance social brasileiro". In: INSTITUTO MOREIRA SALLES, Cadernos de literatura brasileira. Número 3. São Paulo: IMS, 1997, p. 98-119.

MAGALHÃES, Violante. Sobressalto e espanto: narrativas literárias sobre e para a infância, no neo-realismo português. Lisboa: Universidade de Lisboa, 2008 [TESE].

MARTINS, Milena Ribeiro. "Negrinha”. In: LAJOLO, Marisa (org.). Monteiro Lobato, livro a livro: obra adulta. São Paulo: UNESP, 2014, p. 43-58.

MATTOSO, Kátia de Queirós. “O filho da escrava (em torno da Lei do Ventre Livre)”. In: DEL PRIORE, M. (org.). História da criança no Brasil. São Paulo: Contexto, 1991, p. 37-55.

MONTELLO, Josué. "O romancista José Lins do Rego". Transcrição da conferência proferida na ABL, em 15.5.2001, encerrando o ciclo Centenário de José Lins do Rego.

NUNES, Cassiano. A correspondência de Monteiro Lobato. São Paulo: 1982. . Cartas de Monteiro Lobato a uma senhora amiga. São Paulo: 1983.

NUNES, Brasilmar Ferreira. Sociedade e infância no Brasil. Brasília: Editora da Universidade de Brasília (UnB), 2003.

PAES, José Paulo. “Amor/humor por via postal” In: RAMOS, G. Cartas de amor a Heloísa. 3. ed. Rio de Janeiro: Record, 1996, p. 7-23

POLLOCK, Thomas Clark. The nature of literature, its relation to science, language and human experience. Princeton: University of Princeton, 1942. APUD CANDIDO, Antonio. Literatura e sociedade. São Paulo: Nacional, 1967.

POMPEIA, Raul. O Ateneu. Rio de Janeiro: Zahar, 2015.

POSTMAN, Neil. O desaparecimento da infância. Trad. Suzana Carvalho \& José Laurenio de Melo. Rio de Janeiro: Graphia, 2008.

PROENÇA, Ivan Cavalcanti. "Dois momentos sobre José Lins do Rego e Menino de engenho" In: REGO, José Lins. Menino de engenho. 105. ed. Rio de Janeiro: José Olympio, 2013. 
QUEIROZ, R. “Menino de engenho, 40 anos”. In: REGO, J. L. Menino de engenho. 105. ed. Rio de Janeiro: José Olympio, 2013.

RAMOS, Graciliano. “Um novo ABC" in: Linhas tortas. 21. ed. Rio de Janeiro: Record, 2005, p. 248-250.

Vidas secas. 128. ed. Rio de Janeiro: Record, 2015.

RAMOS, Ricardo. Graciliano: retrato fragmentado. São Paulo: Siciliano, 1992.

RAMOS FILHO, Ricardo de Medeiros. Arte literária em dois ramos "graciliânicos": adulto e infantil. São Paulo: USP, 2013 [DISSERTAÇÃO].

REGO, José Lins do. Meus verdes anos. Rio de Janeiro: José Olympio, 1956.

Doidinho. 49. ed. Rio de Janeiro: José Olympio, 2013.

. "Notas sobre Gilberto Freyre" IN: FREYRE, Gilberto. Região e tradição. Rio de Janeiro: José Olympio, 1941 apud CASTELLO, J. A. José Lins do Rego: Modernismo e Regionalismo. São Paulo: Edart, 1961.

REIS, Carlos Nelson do e PRANTES, Jane Cruz (Orgs.). Fragmentos de uma Metrópole: meninos e meninas em situação de rua. Porto Alegre: Edipucrs, 1999.

RESENDE, Vania Maria. O menino na literatura brasileira. São Paulo: Perspectiva, 1988.

RIO, João do. A alma encantadora das ruas. São Paulo: Cia. das Letras, 2008.

RIZZINI, Irma. "Pequenos trabalhadores do Brasil” IN: DEL PRIORE, Mary (org.) História das crianças no Brasil. 7. ed. São Paulo: Contexto, 2013, p. 376-406.

RODARI, Gianni. Gramática da fantasia. 9. ed. São Paulo: Summus, 1982.

SAINT-EXUPÉRY, Antoine . Le Petit Prince. Paris: Gallimard Jeunesse, 1997.

SANTOS, Maria Walburga. "Crianças no tempo presente: a sociologia da infância no Brasil”. Pro-Posições, V. 23, N. 2. Campinas: Unicamp, 2012.

SANTOS, Ricardo Maria. "As transformações do conceito de infância em Grandes esperanças, de Charles Dickens" IN: Mediações - Revista de Ciências Sociais, V. 10, N.1, Londrina: Universidade Estadual de Londrina, 2005, p. 9-24.

SIMPSON, Eileen. "Literary orphans" In: Orphans: real and imaginary. New York: Penguin Books, 1990.

SOUZA NETO, João Clemente. Crianças e adolescentes abandonados: estratégias de sobrevivência. São Paulo: Arte Impressa, 2001. 
TAVARES, Fabiana. Quase como antes: a (des)construção das representações de infância da classe trabalhadora na literatura infantil e juvenil. São Paulo: USP, 2014 [TESE].

TRIGO, Luciano. Engenho e memória: O Nordeste do açúcar na ficção de José Lins do Rego. Rio de Janeiro: Topbooks, 2002.

VALDEZ, Diane, RODRIGUES, Ana Flávia \& OLIVEIRA, Wanessa de Andrade. "Livros solicitados para a infância escolar: Província de Goiás (Século XIX)" in BARRA, V. M. L. Estudos de história da educação de Goiás (1830-1930). Goiânia: Editora da PUC-G0, 2011.

VALDEZ, Diane. A representação de infância nas propostas pedagógicas do Dr. Abilio Cesar Borges: o barão de Macahubas (1856-1891). Campinas: UNICAMP, 2006 [TESE].

VILLAÇA, Antonio Carlos. "Menino de engenho" IN: REGO, J. L. Menino de engenho. Nota de Carlos Drummond de Andrade; estudo de Antônio Carlos Villaça. 80. ed. Rio de Janeiro; José Olympio, 2001.

ZAVARONI, Dione de Medeiros Lula et al. "A consitituição do infantil na obra de Freud". In: Estudos de Psicologia. Brasília: Universidade de Brasília (UnB), 2007, p. 65-70.

ZILBERMAN, Regina. A literatura infantil na escola. 11. ed. São Paulo: Global, 2003. . (Org.) Atualidade de Monteiro Lobato. Porto Alegre: Mercado Aberto, 1983.

"Raul Pompeia, Abílio César Borges e a escola brasileira no século XIX”. Revista Criação \& Crítica, n. 9, P. 38-51, nov. 2012. Disponível em http://www.revistas.usp.br/criacaoecritica. Acesso em 20/10/2016. 


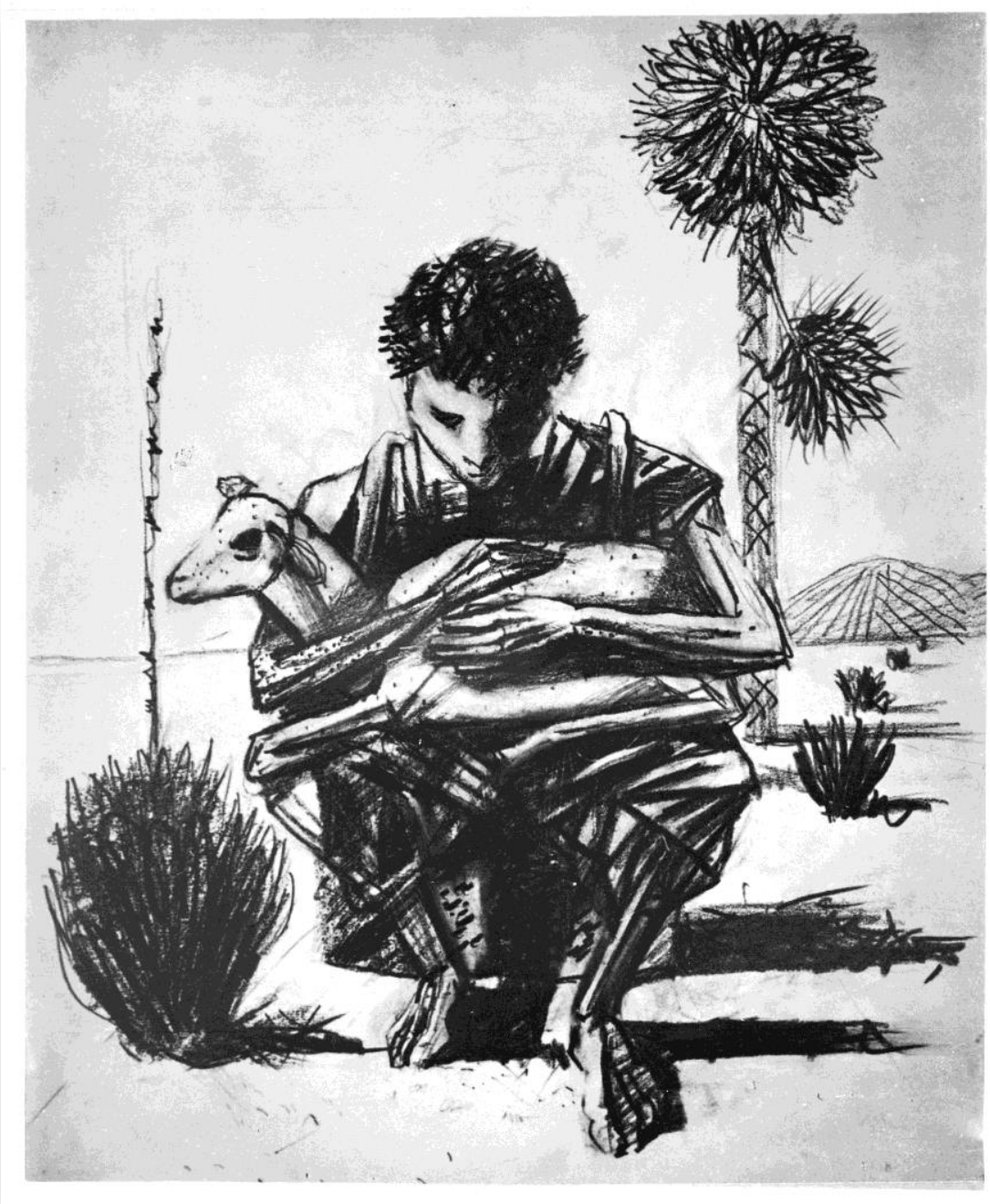

Candido Portinari. Menino com carneiro $(1954)^{348}$

"Dizem que somos pessimistas e exibimos deformações; contudo as deformações e a miséria existem fora da arte e são cultivadas pelos que nos censuram".

(trecho de carta de Graciliano Ramos a Candido Portinari, fevereiro de 1946)

${ }^{348}$ Fonte: portinari.org.br 